\title{
Total Synthesis of the Putative Structure of Asperipin-2a and Stereochemical Reassignment
}

\author{
Sadegh Shabani, Jonathan M. White, Craig A. Hutton* \\ School of Chemistry and Bio21 Molecular Science and Biotechnology Institute, \\ The University of Melbourne, Victoria, Australia, 3010
}

\section{Supplementary Information}

\section{Contents}

Experimental Procedures

S2-S27

NMR and mass spectra

S28-S79

HPLC traces

S80-S85

X-ray crystallography data

S86-S88

References

S89 


\section{General Information}

${ }^{1} \mathrm{H}$ NMR spectra were recorded using an Agilent $500(500 \mathrm{MHz})$ or a Varian Unity Inova $400(400 \mathrm{MHz})$ or a Varian Unity Inova $600(600 \mathrm{MHz})$ or a Bruker $600(600 \mathrm{MHz})$. Spectra were obtained in $\mathrm{CDCl}_{3}$ (7.26), DMSO- $d_{6}(2.50)$, acetone- $d_{6}(2.05)$ or $\mathrm{CD}_{3} \mathrm{OD}$ (3.31). The spectra are reported as: parts per million ( $\mathrm{ppm}$ ) downfield shift, relative to the residual solvent peak; relative integral, multiplicity ( $\mathrm{s}=$ singlet, $\mathrm{br}=$ broad, $\mathrm{d}=$ doublet, $\mathrm{t}=$ triplet, $\mathrm{q}=$ quartet, $\mathrm{dd}=$ doublet of doublets, $\mathrm{dt}=$ doublet of triplets, $\mathrm{dq}$ doublet of quartets, $\mathrm{m}=$ multiplet) and coupling constant $(\mathrm{J}$ in $\mathrm{Hz}) \cdot{ }^{13} \mathrm{C}$ NMR spectra were recorded using an Agilent $500(125 \mathrm{MHz})$ or a Varian Unity Inova $600(150 \mathrm{MHz})$ or a Bruker $600(600 \mathrm{MHz})$. Chemical shifts $(\delta)$ are reported in parts per million (ppm) relative to the internal standard of the solvent peak; $\mathrm{CDCl}_{3}$ (77.16), DMSO- $d_{6}$ (39.52), acetone- $d_{6}$ (29.84 and 206.26), or $\mathrm{CD}_{3} \mathrm{OD}$ (49.00). All mass spectra were recorded on an MSFP OrbiTRAP infusion Mass Spectrometer. Most reagents were commercially available reagent grade chemicals and were used without further purification. DMSO was distilled over calcium hydride. Anhydrous THF, $\mathrm{Et} 2 \mathrm{O}, \mathrm{DMF}, \mathrm{CH}_{3} \mathrm{OH}, \mathrm{CH}_{3} \mathrm{CN}$ and $\mathrm{CH}_{2} \mathrm{Cl}_{2}$ were obtained from a solvent drying and dispensing system where the solvent was dried by passage through two packed columns of neutral alumina. Powdered molecular sieves were activated with a microwave and allowed to cool under vacuum. Analytical thin layer chromatography was performed with aluminium backed plates precoated with silica gel $60 \mathrm{~F} 254(0.2 \mathrm{~mm})$, and visualization was achieved by inspection under shortwave UV light followed by staining with phosphomolybdic acid dip [polyphosphomolybdic acid (12 g), ethanol (250mL)]. Flash chromatography was performed using silica gel (230-400 mesh); eluting solvents reported as \% v/v mixtures. Analytical, preparative and chiral reverse phase HPLC (RPHPLC) were performed using an Agilent 1200 series LC System. Analytical HPLC employed a Discovery C18 column $\left(4.6 \times 150 \mathrm{~mm}\right.$ column, $5 \mu \mathrm{m}$ particle size, flow rate of $\left.1 \mathrm{~mL} \mathrm{~min}^{-1}\right)$. Preparative RP-HPLC employed a Phenomenex C18 column $\left(21.2 \times 150 \mathrm{~mm}, 5 \mu \mathrm{m}\right.$ particle size, flow rate $\left.8 \mathrm{~mL} \mathrm{~min}^{-1}\right)$. The mobile phase consisted of eluents A (0.1\% TFA in water) and B ( $0.1 \%$ TFA in acetonitrile). A linear gradient from 10-95\% eluent B over 50 min was used for the preparative HPLC. A linear gradient from $0-100 \%$ eluent B over 30 min was used for the analytical HPLC. The results were analyzed on Agilent ChemStation version B.01.03 software. 


\section{(R)-2,2-Dimethyl-1,3-dioxolane-4-carbaldehyde (2)}

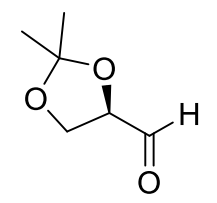

Following the procedure of Zhong, ${ }^{1} \mathrm{NaIO}_{4}(25.7 \mathrm{~g}, 120 \mathrm{mmol})$ was dissolved in hot water $(550 \mathrm{ml})$. Silica gel (100 g) was added to the mixture and with vigorous mixing and shaking. The silica gelsupported $\mathrm{NaIO}_{4}(190 \mathrm{~g})$ was suspended in DCM $(950 \mathrm{ml})$ and the mixture was stirred vigorously. 1,2:5,6-di-O-Isopropylidene-D-mannitol ${ }^{2}$ (50 g, $\left.190 \mathrm{mmol}\right)$ was dissolved in DCM (950 ml) and added to the suspension. The resulting mixture was stirred for $40 \mathrm{~min}$ and filtered. The silica was washed with DCM and the solvent was evaporated under reduced pressure. The compound was distilled under reduced pressure to give the $(R)$-2,2-dimethyl-1,3-dioxolane-4-carbaldehyde $2(90 \%, 14.0 \mathrm{~g})$ as a colorless oil

which directly used in the next step. ${ }^{1} \mathbf{H}$ NMR $\left(600 \mathrm{MHz}, \mathrm{CDCl}_{3}\right) \delta 9.70(\mathrm{~s}, 1 \mathrm{H}), 4.37(\mathrm{~m}, 1 \mathrm{H}), 4.16$ (ddd, $J=8.6,7.5,1.0 \mathrm{~Hz}, 1 \mathrm{H}), 4.09$ (ddd, $J=8.9,4.6,1.0 \mathrm{~Hz}, 1 \mathrm{H}), 1.47(\mathrm{~s}, 3 \mathrm{H}), 1.41(\mathrm{~s}, 3 \mathrm{H}) .{ }^{13} \mathrm{C}$ NMR $\left(151 \mathrm{MHz}, \mathrm{CDCl}_{3}\right) \delta 201.8,111.2,79.8,65.5,26.2,25.1$.

\section{$(R)-((R)-2,2-D i m e t h y l-1,3-d i o x o l a n-4-y l)($ phenyl)methanol (3)}

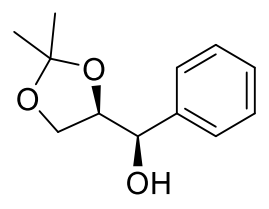

Using a modification of the procedure of Kusakabe, ${ }^{3}$ phenylmagnesium bromide $(1.0 \mathrm{M}$ solution in THF, $92 \mathrm{ml}, 92.0 \mathrm{mmol})$ was added to a solution of CuI $(20.4 \mathrm{~g}, 10.6 \mathrm{mmol})$ in a mixture of THF-DMS solution $(5: 1,460 \mathrm{ml})$ at $-78^{\circ} \mathrm{C}$ under argon atmosphere. The mixture was stirred for $20 \mathrm{~min}$ at same temperature. (R)-2,2-dimethyl-1,3-dioxolane-4-carbaldehyde 2 (10 g, $77.2 \mathrm{mmol})$ was added dropwise and the reaction was stirred for $2 \mathrm{~h}$ at $-78^{\circ} \mathrm{C}$. The mixture was gradually warmed to room temperature over a period of $2 \mathrm{~h}$. The reaction was quenched with aq. $\mathrm{NH}_{4} \mathrm{Cl}$ and $\mathrm{NH}_{4} \mathrm{OH}$ to adjust the $\mathrm{pH}$ to 9 . The mixture 
was extracted with EtOAc $(3 \times 500 \mathrm{ml})$. The combined organic layers were washed with saturated $\mathrm{NH}_{4} \mathrm{Cl}$ (400 $\mathrm{ml})$ and brine $(400 \mathrm{ml})$ and dried over magnesium sulfate. The purification was performed using column chromatography $(25 \%$ EtOAc/Hex $)$ to give the alcohol $\mathbf{3}(85 \%, 12.8 \mathrm{~g})$ as colourless crystals. The compound was recrystallized from EtOAc/Hex to produce crystals suitable for X-ray crystallography. M.p.: $39-41{ }^{\circ} \mathrm{C} .{ }^{1} \mathbf{H}$ NMR $\left(600 \mathrm{MHz}, \mathrm{CDCl}_{3}\right) \delta 7.36-7.27(\mathrm{~m}, 5 \mathrm{H}), 4.53(\mathrm{~m}, 1 \mathrm{H}), 4.19$ $(\mathrm{m}, 1 \mathrm{H}), 3.87(\mathrm{~m}, 1 \mathrm{H}), 3.70(\mathrm{~m}, 1 \mathrm{H}), 2.90(\mathrm{~m}, 1 \mathrm{H}), 1.47(\mathrm{~s}, 3 \mathrm{H}), 1.35(\mathrm{~s}, 3 \mathrm{H}) .{ }^{13} \mathbf{C}$ NMR $(151 \mathrm{MHz}$, $\left.\mathrm{CDCl}_{3}\right) \delta 139.7,128.6,128.4,126.9,110.1,80.2,75.9,66.0,26.9,25.4$. HRMS (ESI) $\left.m / z:[\mathrm{M}+\mathrm{H}]^{+}\right)$ calcd for $\mathrm{C}_{12} \mathrm{H}_{17} \mathrm{O}_{3} 209.1172$; found 209.1178 .

\section{3-(tert-Butyl) 4-methyl (4S,5R)-5-(4-((tert-butoxycarbonyl)oxy)phenyl)-2-oxazolidin-2-one-3,4- dicarboxylate (S1)}

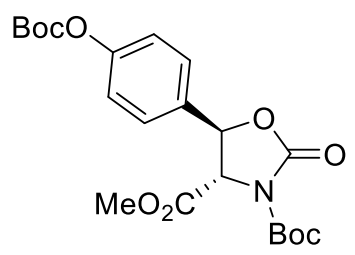

Following the method of Crich, ${ }^{4}$ a mixture of Boc $_{2}$-Tyr(Boc)-OMe 4 (5.64 g, $\left.11.4 \mathrm{mmol}\right)$ and NBS (2.0 $\mathrm{g}, 11.4 \mathrm{mmol}, 1 \mathrm{eq})$ in $\mathrm{CCl}_{4}(228 \mathrm{ml})$ was heated (oil bath) at reflux for $90 \mathrm{~min}$ under argon while being irradiated under a mercury lamp. The mixture was cooled, filtered, and concentrated under vacuum. The residue was then dissolved in acetone $(228 \mathrm{ml})$ and silver nitrate $(2.85 \mathrm{~g}, 17.1 \mathrm{mmol}, 1.5 \mathrm{eq})$ was added. The reaction mixture was stirred for $4 \mathrm{~h}$ at room temperature in the dark. The mixture was then filtered and concentrated. The residue was dissolved in EtOAc $(100 \mathrm{ml})$ and washed with saturated $\mathrm{NH}_{4} \mathrm{Cl}$ solution $(100 \mathrm{ml})$, water $(100 \mathrm{ml})$, and brine $(100 \mathrm{ml})$. The product was dried over magnesium sulfate and purified using column chromatography (EtOAc/Hex, 30-70\%) to give the corresponding oxazolidinone S1 (5.0 g, 65\%) as a white solid. m.p 50-52 ${ }^{\circ} \mathrm{C},[\alpha]^{25} \mathrm{D}+54\left(c 0.27\right.$, acetone). ${ }^{1} \mathbf{H}$ NMR 
$\left(500 \mathrm{MHz}, \mathrm{CDCl}_{3}\right) \delta 7.44-7.38(\mathrm{~m}, 2 \mathrm{H}), 7.30-7.23(\mathrm{~m}, 3 \mathrm{H}), 5.40(\mathrm{~d}, J=4.2 \mathrm{~Hz}, 1 \mathrm{H}), 4.63(\mathrm{~d}, J=4.2 \mathrm{~Hz}$, 1H), $3.90(\mathrm{~s}, 3 \mathrm{H}), 1.57$ (s, 9H), 1.51 (s, 9H). ${ }^{13} \mathbf{C}$ NMR (151 MHz, $\left.\mathrm{CDCl}_{3}\right) \delta$ 169.1, 156.6, 150.7, 148.50131.3, 130.8, 126.0, 124.5, 124.3, 84.8, 79.1, 75.9, 63.6, 53.2, 28.8, 27.8. HRMS (ESI) $\mathrm{m} / \mathrm{z}$ : $[\mathrm{M}+\mathrm{Na}]^{+}$) calcd for $\mathrm{C}_{21} \mathrm{H}_{27} \mathrm{NO}_{9} \mathrm{Na} 460.1578$; found 460.1581 .

\section{Methyl (4S,5R)-5-(4-hydroxyphenyl)-oxazolidin-2-one-4-carboxylate (5)}

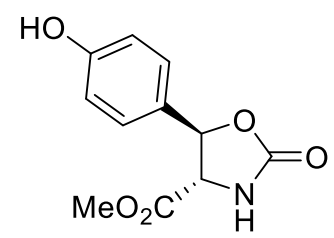

The 3-(tert-butyl) 4-methyl (4S,5R)-5-(4-((tert-butoxycarbonyl)oxy)phenyl)-2-oxazolidin-2-one-3,4-dicarboxylate S1 (200 mg, $0.45 \mathrm{mmol})$ was dissolved in TFA/DCM (1:3,2 ml) containing triethylsilane $(0.1 \mathrm{ml}, 0.90 \mathrm{mmol}, 2 \mathrm{eq})$. The mixture was stirred for $1 \mathrm{~h}$ then the solvent was evaporated under reduced pressure. The residue was purified by column chromatography $(75 \% \mathrm{EtOAc} / \mathrm{Hex})$ to afford the title compound 5 in near quantitative yield (105 mg, 99\%) as a yellow oil. ${ }^{1} \mathbf{H}$ NMR (600 MHz, acetone- $\left.d_{6}\right)$ $\delta 8.89(\mathrm{~s}, 1 \mathrm{H}), 7.35(\mathrm{~s}, 1 \mathrm{H}), 7.29(\mathrm{~d}, J=8.8 \mathrm{~Hz}, 2 \mathrm{H}), 6.89(\mathrm{~d}, J=8.6 \mathrm{~Hz}, 2 \mathrm{H}), 5.51(\mathrm{~d}, J=4.9 \mathrm{~Hz}, 1 \mathrm{H}), 4.39$ (dd, $J=5.0,1.0 \mathrm{~Hz}, 1 \mathrm{H}), 3.77(\mathrm{~s}, 3 \mathrm{H}) .{ }^{13} \mathbf{C}$ NMR $\left(151 \mathrm{MHz}\right.$, acetone- $\left.d_{6}\right) \delta 170.7,158.2,157.8,129.7$, 127.4, 115.6, 79.1, 61.2, 52.2. HRMS (ESI) $\mathrm{m} / z$ : $[\mathrm{M}+\mathrm{H}]^{+}$) calcd for $\mathrm{C}_{11} \mathrm{H}_{12} \mathrm{NO}_{5}$ 238.0710; found 238.0712 .

Methyl (4S,5R)-5-(4-((S)-((R)-2,2-dimethyl-1,3-dioxolan-4-yl)(phenyl)methoxy)phenyl)oxazolidin-2-one-4-carboxylate (6) 


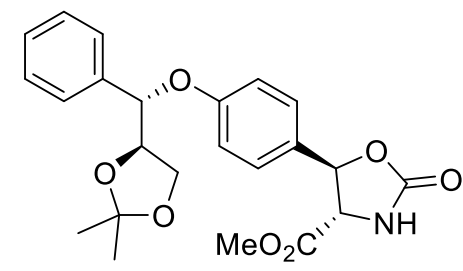

Oxazolidinone 5 (108 mg, $0.45 \mathrm{mmol}$ ), alcohol 3 (100 mg, $0.48 \mathrm{mmol}$ ), and $\mathrm{PPh}_{3}(124 \mathrm{mg}, 0.48 \mathrm{mmol})$ were dissolved in THF (160 $\mu$ ) and sonicated for 5 min to afford a homogenous mixture. DIAD (93 $\mu$ l, $0.48 \mathrm{mmol}$ ) was added to the mixture dropwise and the reaction sonicated for $1 \mathrm{~h}$. The solvent was evaporated and purification was done using column chromatography (EtOAc/Hex, 25-65\%) to give the product $\mathbf{6}(45 \%, 86 \mathrm{mg})$ as a white solid. ${ }^{1} \mathbf{H} \mathbf{~ N M R}\left(500 \mathrm{MHz}, \mathrm{CDCl}_{3}\right) \delta 7.41-7.33(\mathrm{~m}, 5 \mathrm{H}), 7.3(\mathrm{~m}, 1 \mathrm{H})$, 7.26-7.21 (m, 2H), $6.88(\mathrm{~d}, J=8.8 \mathrm{~Hz}, 2 \mathrm{H}), 6.08(\mathrm{~s}, 1 \mathrm{H}), 5.53(\mathrm{~d}, J=5.0 \mathrm{~Hz}, 1 \mathrm{H}), 5.11(\mathrm{~d}, J=6.1 \mathrm{~Hz}, 1 \mathrm{H})$, $4.40(\mathrm{dt}, J=6.3,5.3 \mathrm{~Hz}, 1 \mathrm{H}), 4.24-4.16(\mathrm{~m}, 2 \mathrm{H}), 4.11(\mathrm{dd}, J=8.7,6.4 \mathrm{~Hz}, 1 \mathrm{H}), 3.82(\mathrm{~s}, 3 \mathrm{H}), 1.48(\mathrm{~s}, 3 \mathrm{H})$, $1.36(\mathrm{~s}, 3 \mathrm{H}) .{ }^{13} \mathbf{C}$ NMR $\left(126 \mathrm{MHz}, \mathrm{CDCl}_{3}\right) \delta 170.1,158.4,157.9,137.8,132.1,130.4,128.7,128.3,126.9$, 126.7, 116.4, 110.0, 80.4, 79.1, 66.2, 61.2, 53.1, 26.7, 25.4. HRMS (ESI) $m / z:[\mathrm{M}+\mathrm{H}]^{+}$) calcd for $\mathrm{C}_{23} \mathrm{H}_{26} \mathrm{NO}_{7} 428.1704$; found 428.1702 .

\section{Methyl (4S,5R)-5-(4-((S)-((R)-2,2-dimethyl-1,3-dioxolan-4-yl)(phenyl)methoxy)phenyl)-3-((4- nitrophenyl)sulfonyl)-oxazolidin-2-one-4-carboxylate (7)}

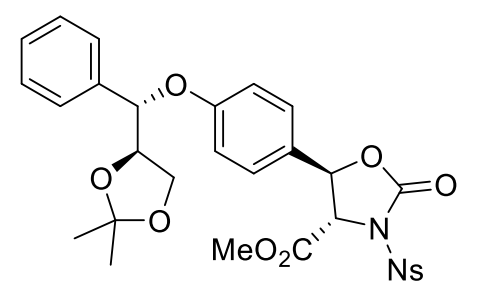

Oxazolidine $6(180 \mathrm{mg}, 0.52 \mathrm{mmol})$ was dissolved in THF $(2 \mathrm{ml})$ at $-78^{\circ} \mathrm{C}$ under argon atmosphere. KHMDS $(0.58 \mathrm{ml}, 0.58 \mathrm{mmol}, 1.1 \mathrm{eq})$ was added dropwise to the reaction mixture and the mixture was stirred for $10 \mathrm{~min}$ at same temperature. A solution of $\mathrm{NsCl}(142 \mathrm{mg}, 0.64 \mathrm{mmol}, 1.2 \mathrm{eq})$ in $\mathrm{THF}(2 \mathrm{ml})$ was added dropwise and the mixture was stirred at $-78^{\circ} \mathrm{C}$ for additional $2 \mathrm{~h}$. The reaction was quenched 
with $1 \mathrm{M} \mathrm{HCl}$ and extracted with EtOAc $(3 \times 5 \mathrm{ml})$. The combined organic layers were washed with $1 \mathrm{M}$ $\mathrm{HCl}(10 \mathrm{ml})$, brine $(10 \mathrm{ml})$ and dried over magnesium sulfate. The product was purified using column chromatography (40\% EtOAc/Hex) to give the product $7(270 \mathrm{mg}, 83 \%)$ as a yellow solid. ${ }^{1} \mathbf{H}$ NMR $\left(600 \mathrm{MHz}, \mathrm{CDCl}_{3}\right) \delta 8.38(\mathrm{~d}, J=9.0 \mathrm{~Hz}, 2 \mathrm{H}), 8.31(\mathrm{~d}, J=9.0 \mathrm{~Hz}, 2 \mathrm{H}), 7.39-7.33(\mathrm{~m}, 5 \mathrm{H}), 7.33-7.27(\mathrm{~m}$, 2H), $7.14(\mathrm{~d}, J=8.7 \mathrm{~Hz}, 2 \mathrm{H}), 6.89(\mathrm{~d}, J=8.8 \mathrm{~Hz}, 2 \mathrm{H}), 5.35(\mathrm{~d}, J=4.2 \mathrm{~Hz}, 1 \mathrm{H}), 5.11(\mathrm{~d}, J=6.1 \mathrm{~Hz}, 1 \mathrm{H}), 4.88$ (d, $J=4.2 \mathrm{~Hz}, 1 \mathrm{H}), 4.39(\mathrm{td}, J=6.3,5.3 \mathrm{~Hz}, 1 \mathrm{H}), 4.17(\mathrm{dd}, J=8.7,5.3 \mathrm{~Hz}, 1 \mathrm{H}), 4.13-4.07$ (m, 2H), 3.85 (s, 3H), 1.46 (s, 3H), $1.34(\mathrm{~s}, 3 \mathrm{H}) .{ }^{13} \mathbf{C}$ NMR $\left(151 \mathrm{MHz}, \mathrm{CDCl}_{3}\right) \delta 168.3,159.1,151.1,150.4,142.4,137.5$, $130.8,128.8,128.4,128.1,128.0126 .8,126.7,126.7,123.9,123.9,116.8,110.1,80.5,79.0,78.1,66.1$, 64.1, 53.7, 26.6, 25.3. HRMS (ESI) $m / z:[\mathrm{M}+\mathrm{H}]^{+}$) calcd for $\mathrm{C}_{29} \mathrm{H}_{28} \mathrm{~N}_{2} \mathrm{NaO}_{11} \mathrm{~S}$ 635.1306; found 635.1308.

(2S,3R)-3-(4-((S)-((R)-2,2-Dimethyl-1,3-dioxolan-4-yl)(phenyl)methoxy)phenyl)-3-hydroxy-2-((4nitrophenyl)sulfonamido)propanoic acid (8)

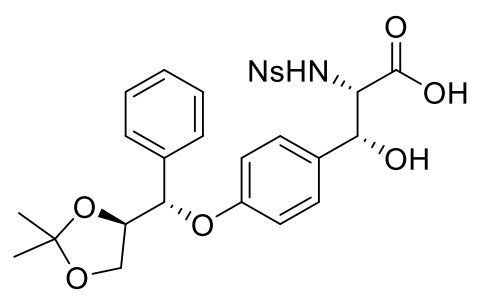

Oxazolidinone 7 (500 mg, $0.82 \mathrm{mmol})$ was dissolved in MeOH/DCM (1:1, $5 \mathrm{ml})$ and $\mathrm{Cs}_{2} \mathrm{CO}_{3}(160 \mathrm{mg}$, $0.5 \mathrm{mmol}$ ) was added at $-15^{\circ} \mathrm{C}$, the mixture was stirred for $5 \mathrm{~h}$ then solvent was evaporated. The residue was dissolved in EtOAc $(10 \mathrm{ml})$, washed with $1 \mathrm{~N} \mathrm{HCl}(5 \mathrm{ml})$, brine $(5 \mathrm{ml})$, and dried over magnesium sulfate. The solvent was evaporated and residue was redissolved in dioxane $(5 \mathrm{ml})$. $\mathrm{LiOH}(98 \mathrm{mg}, 4.1$ mmol) in water $(0.5 \mathrm{ml})$ was added at $0{ }^{\circ} \mathrm{C}$. The reaction was warmed up to room temperature and stirred for $3 \mathrm{~h}$. The mixture was quenched with $1 \mathrm{~N} \mathrm{HCl}$ and $\mathrm{pH}$ was adjusted to 4 . Water $(10 \mathrm{ml})$ was added and the mixture was extracted with EtOAc $(3 \times 10 \mathrm{ml})$. The combined organic layers were washed with brine $(20 \mathrm{ml})$ and dried over magnesium sulfate. The purification was performed using column 
chromatography $(20 \% \mathrm{MeOH} / \mathrm{DCM})$ to give the $\beta$-hydroxytyrosine derivative $\mathbf{8}(370 \mathrm{mg}, 85 \%)$ as a white solid. ${ }^{1} \mathrm{H}$ NMR (600 MHz, $\left.\mathrm{CD}_{3} \mathrm{OD}\right) \delta 8.15(\mathrm{~d}, J=8.7 \mathrm{~Hz}, 2 \mathrm{H}), 7.73(\mathrm{~d}, J=8.5 \mathrm{~Hz}, 2 \mathrm{H}), 7.40-7.34$ (m, 2H), $7.30(\mathrm{t}, J=7.7 \mathrm{~Hz}, 2 \mathrm{H}), 7.26-7.21(\mathrm{~m}, 1 \mathrm{H}), 7.09(\mathrm{~d}, J=8.2 \mathrm{~Hz}, 2 \mathrm{H}), 6.64(\mathrm{~d}, J=8.3 \mathrm{~Hz}, 2 \mathrm{H}), 5.07$ $(\mathrm{d}, J=6.0 \mathrm{~Hz}, 1 \mathrm{H}), 5.01(\mathrm{~s}, 1 \mathrm{H}), 4.38(\mathrm{q}, J=6.1 \mathrm{~Hz}, 1 \mathrm{H}), 4.10(\mathrm{dq}, J=8.7,6.2 \mathrm{~Hz}, 2 \mathrm{H}), 4.0(\mathrm{~m}, 1 \mathrm{H}), 1.37$ (s, 3H), 1.30 (s, 3H). ${ }^{13} \mathbf{C}$ NMR (151 MHz, CD 3 OD) $\delta 157.1,149.6,146.8,138.2,133.8,128.0,127.8$, 127.7, 127.2, 127.0, 123.5, 115.3, 109.6, 80.4, 79.0, 73.0, 66.0, 62.8, 25.4, 24.3. HRMS (ESI) $m / z$ : $[\mathrm{M}+\mathrm{H}]^{+}$) calcd for $\mathrm{C}_{27} \mathrm{H}_{27} \mathrm{~N}_{2} \mathrm{O}_{10} \mathrm{~S}$ 571.1392; found 571.1391.

tert-Butyl O-benzyl-N-((2S,3R)-3-(4-((S)-((R)-2,2-dimethyl-1,3-dioxolan-4-yl)(phenyl)methoxy)phenyl)-3-hydroxy-2-((4-nitrophenyl)sulfonamido)propanoyl)-L-threonylglycinate (10)

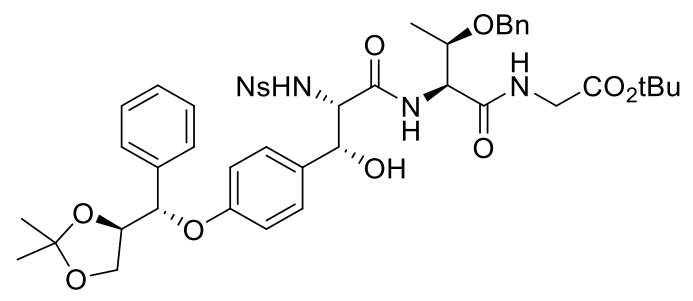

To a solution of $\beta$-hydroxytyrosine 8 (73 mg, $0.14 \mathrm{mmol})$ in DMF (1 ml), EDC.Cl (30 mg, $0.157 \mathrm{mmol}$, $1.1 \mathrm{eq})$ and HOBt $(21 \mathrm{mg}, 0.157 \mathrm{mmol} 1.1 \mathrm{eq})$ were added and the mixture was stirred at room temperature for $5 \mathrm{~min}$. Thr(Bn)-Gly-OtBu${ }^{5} 9(92 \mathrm{mg}, 0.286 \mathrm{mmol}, 2 \mathrm{eq})$ and $\mathrm{NEt}_{3}(41 \mu 1,0.286 \mathrm{mmol}$, 2 eq) were added and the reaction mixture was stirred overnight. Water $(2 \mathrm{ml})$ was then added and the mixture was extracted with EtOAc $(3 \times 5 \mathrm{ml})$. The extracts were washed with $1 \mathrm{~N} \mathrm{HCl}(10 \mathrm{ml}), \mathrm{NaHCO}_{3}$ $(10 \mathrm{ml})$ brine $(10 \mathrm{ml})$ and dried over magnesium sulfate. The crude material was purified using column chromatography $\left(50 \%\right.$ EtOAc/Hex) to give the compound $\mathbf{1 0}$ as a white foam $(90 \mathrm{mg}, 80 \%) .{ }^{\mathbf{1}} \mathbf{H}$ NMR $\left(600 \mathrm{MHz}, \mathrm{CDCl}_{3}\right) \delta 8.02(\mathrm{~d}, J=8.8 \mathrm{~Hz}, 2 \mathrm{H}), 7.66(\mathrm{~d}, J=8.8 \mathrm{~Hz}, 2 \mathrm{H}), 7.46(\mathrm{~d}, J=7.8 \mathrm{~Hz}, 1 \mathrm{H}), 7.35-7.30$ (m, 5H), 7.30-7.25 (m, 2H), 7.24-7.16 (m, 7H), $6.91(\mathrm{~d}, J=8.8 \mathrm{~Hz}, 2 \mathrm{H}), 6.61(\mathrm{~d}, J=8.8 \mathrm{~Hz}, 2 \mathrm{H}), 5.96(\mathrm{~s}$, $1 \mathrm{H}), 5.01(\mathrm{~d}, J=6.2 \mathrm{~Hz}, 1 \mathrm{H}), 4.92(\mathrm{~d}, J=3.2 \mathrm{~Hz}, 1 \mathrm{H}), 4.56-4.46(\mathrm{~m}, 4 \mathrm{H}), 4.38(\mathrm{~m}, 1 \mathrm{H}), 4.17(\mathrm{dd}, J=8.8$, 
$5.3 \mathrm{~Hz}, 1 \mathrm{H}), 4.12(\mathrm{~m}, 1 \mathrm{H}), 4.9(\mathrm{~m}, 1 \mathrm{H}), 3.90(\mathrm{dd}, J=17.9,5.8 \mathrm{~Hz}, 1 \mathrm{H}), 3.86(\mathrm{~d}, J=2.9 \mathrm{~Hz}, 1 \mathrm{H}), 3.85-3.79$ (m, 2H), $3.76(\mathrm{~d}, J=3.7 \mathrm{~Hz}, 1 \mathrm{H}), 1.44(\mathrm{~s}, 3 \mathrm{H}), 1.41(\mathrm{~s}, 9 \mathrm{H}), 1.34(\mathrm{~s}, 3 \mathrm{H}), 1.04(\mathrm{~d}, J=6.4 \mathrm{~Hz}, 3 \mathrm{H}) .{ }^{13} \mathrm{C}$ $\operatorname{NMR}\left(151 \mathrm{MHz}, \mathrm{CDCl}_{3}\right) \delta 169.3,169.0,168.5,157.8,149.9,144.1,137.8,137.4,130.9,128.6,128.4$, $128.4,128.3,127.9,127.7,127.0,126.8,124.0,116.1,110.0,82.3,80.6,79.0,73.8,72.7,71.8,66.3$, 61.9, 57.0, 42.1, 28.0, 28.0, 26.6, 25.3, 15.7. HRMS (ESI) $m / z:[\mathrm{M}+\mathrm{H}]^{+}$) calcd for $\mathrm{C}_{44} \mathrm{H}_{53} \mathrm{~N}_{4} \mathrm{O}_{13} \mathrm{~S}$ 877.3324; found 877.3325.

tert-Butyl O-benzyl-N-((2S,3S)-3-(4-((S)-((R)-2,2-dimethyl-1,3-dioxolan-4-yl)(phenyl)methoxy)phenyl)-1-((4-nitrophenyl)sulfonyl)aziridine-2-carbonyl)-L-threonylglycinate (11)

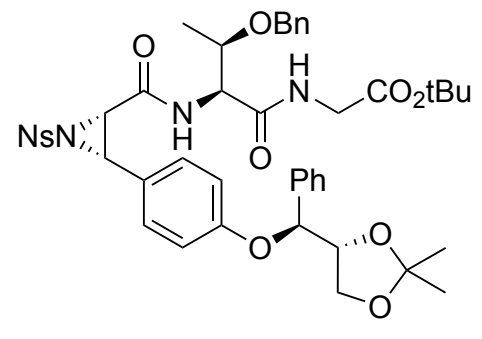

To a flame dried 2-necked RB flask, tripeptide 10 (50 mg, $0.05 \mathrm{mmol})$ was dissolved in THF (6 ml) under argon at $0{ }^{\circ} \mathrm{C}$. Triphenylphosphine $(66 \mathrm{mg}, 0.25 \mathrm{mmol})$ and DIAD $(50 \mu 1,0.25 \mathrm{mml})$ were added and the mixture was stirred for $2 \mathrm{~h}$ at $0{ }^{\circ} \mathrm{C}$. The reaction was warmed up to room temperature and stirred overnight. The compound was directly subjected to column chromatography (EtOAc/Hex, 25-75\%) to give compound 11 (38 mg, 90\%) as a white solid. ${ }^{1} \mathbf{H} \mathbf{~ N M R}\left(600 \mathrm{MHz}, \mathrm{CCDl}_{3}\right) \delta 8.35(\mathrm{~d}, J=8.9 \mathrm{~Hz}, 2 \mathrm{H})$, $8.20(\mathrm{~d}, J=8.9 \mathrm{~Hz}, 2 \mathrm{H}), 7.38-7.30(\mathrm{~m}, 4 \mathrm{H}), 7.30-7.26(\mathrm{~m}, 6 \mathrm{H}), 7.22(\mathrm{~m}, 1 \mathrm{H}), 7.01-6.98(\mathrm{~m}, 2 \mathrm{H}), 6.78$ (d, $J=6.6 \mathrm{~Hz}, 1 \mathrm{H}), 6.66(\mathrm{~d}, J=8.9 \mathrm{~Hz}, 2 \mathrm{H}), 4.95(\mathrm{~d}, J=6.2 \mathrm{~Hz}, 1 \mathrm{H}), 4.41(\mathrm{~s}, 2 \mathrm{H}), 4.32(\mathrm{~m}, 1 \mathrm{H}), 4.24(\mathrm{~d}$, $J=7.8 \mathrm{~Hz}, 1 \mathrm{H}), 4.20$ (dd, $J=6.6,3.0 \mathrm{~Hz}, 1 \mathrm{H}), 4.11-4.03(\mathrm{~m}, 2 \mathrm{H}), 3.84$ (dd, $J=18.1,5.4 \mathrm{~Hz}, 1 \mathrm{H}), 3.75$ (dd, $J=18.0,5.1 \mathrm{~Hz}, 1 \mathrm{H}), 3.65$ (d, $J=7.8 \mathrm{~Hz}, 1 \mathrm{H}), 3.37(\mathrm{~m}, 1 \mathrm{H}), 1.45(\mathrm{~s}, 10 \mathrm{H}), 1.43(\mathrm{~s}, 3 \mathrm{H}), 1.31(\mathrm{~s}, 3 \mathrm{H}), 0.11$ (d, $J=6.4 \mathrm{~Hz}, 3 \mathrm{H}) .{ }^{13} \mathbf{C}$ NMR $\left(151 \mathrm{MHz}, \mathrm{CDCl}_{3}\right) \delta 168.2,168.1,162.8,158.2,151.0,142.8,137.6,129.4$, 128.6, 128.6, 128.4, 128.3, 127.9, 127.9, 126.6, 124.7, 123.0, 116.0, 110.0, 82.3, 80.2, 79.0, 73.2, 71.2, 
66.1, 55.1, 46.0, 45.2, 41.9, 28.0, 26.6, 25.3, 13.6. HRMS (ESI) $m / z$ : $[\mathrm{M}+\mathrm{H}]^{+}$) calcd for $\mathrm{C}_{44} \mathrm{H}_{51} \mathrm{~N}_{4} \mathrm{O}_{12} \mathrm{~S}$ 859.3219; found 859.3220.

\section{Boc-L-tyrosine allyl ester (12)}

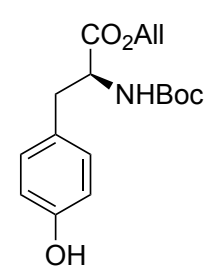

To a solution of Boc-Tyr-OH ( $8.7 \mathrm{~g}, 31 \mathrm{mmol})$ and $\mathrm{K}_{2} \mathrm{CO}_{3}(4.3 \mathrm{~g}, 31 \mathrm{mmol}, 1 \mathrm{eq})$ in DMF (20 ml), allyl bromide ( $2.9 \mathrm{ml}, 34 \mathrm{mmol}, 1.1 \mathrm{eq})$ was added dropwise. The reaction mixture was stirred for $3 \mathrm{~h}$ at room temperature then the volatile compounds were evaporated under reduced pressure. The residue was dissolved in EtOAc $(50 \mathrm{ml})$ and washed with water $(50 \mathrm{ml})$, brine $(50 \mathrm{ml})$, and dried over magnesium sulfate. The compound was purified with column chromatography (20\% EtOAc/Hex) to give product 12 (9.5 g, 95\%). The compound was then crystallized from EtOAc/Hex to yield transparent crystals. m.p $67-69^{\circ} \mathrm{C},[\alpha]^{25} \mathrm{D}-5.23\left(c 0.575\right.$, acetone). ${ }^{1} \mathrm{H}$ NMR $\left(400 \mathrm{MHz}, \mathrm{CDCl}_{3}\right) \delta 6.99(\mathrm{~d}, J=8.4 \mathrm{~Hz}, 2 \mathrm{H}), 6.73$ (d, $J=8.3 \mathrm{~Hz}, 2 \mathrm{H}), 5.87$ (ddt, $J=16.5,11.1,5.9 \mathrm{~Hz}, 1 \mathrm{H}), 5.31(\mathrm{dd}, J=17.2,1.7 \mathrm{~Hz}, 1 \mathrm{H}), 5.25(\mathrm{~d}, J=10.4$ $\mathrm{Hz}, 1 \mathrm{H}), 5.06(\mathrm{~s}, 1 \mathrm{H}), 4.97$ (d, $J=8.4 \mathrm{~Hz}, 1 \mathrm{H}), 4.60(\mathrm{~d}, J=5.8 \mathrm{~Hz}, 2 \mathrm{H}), 4.54(\mathrm{~m}, 1 \mathrm{H}), 3.02(\mathrm{qd}, J=14.0$, $5.9 \mathrm{~Hz}, 2 \mathrm{H}), 1.42(\mathrm{~s}, 9 \mathrm{H}) .{ }^{13} \mathbf{C} \mathbf{N M R}\left(151 \mathrm{MHz}, \mathrm{CDCl}_{3}\right) \delta 171.8,155.2,154.9,131.5,130.5,127.7,118.9$, 115.4, 80.1, 77.2, 767.0, 76.8, 66.0, 54.6, 37.5, 28.3. HRMS (ESI) $\mathrm{m} / z$ : $[\mathrm{M}+\mathrm{H}]^{+}$) calcd for $\mathrm{C}_{17} \mathrm{H}_{24} \mathrm{~N}_{5} \mathrm{O}_{5}$ 322.1649; found 322.1647.

\section{C-terminal macrocycle diol (14)}
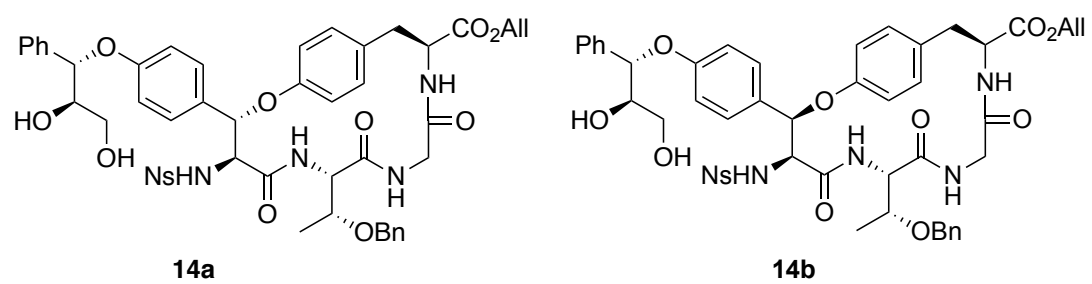
To a flame dried 2-neck RB flask under argon, aziridine 11 (20 mg, $0.023 \mathrm{mmol})$ was dissolved in DCM $(1 \mathrm{ml})$ at $-78{ }^{\circ} \mathrm{C} . \mathrm{BF}_{3} . \mathrm{OEt}_{2}(0.024 \mathrm{mmol}, 17 \mu \mathrm{l})$ was added followed by addition of a solution of BocTyr-OAll 12 (75 mg, $0.234 \mathrm{mmol}, 10 \mathrm{eq})$ in DCM $(1 \mathrm{ml})$. The mixture was stirred for $-78^{\circ} \mathrm{C}$ for $10 \mathrm{~h}$ then overnight at $-25^{\circ} \mathrm{C}$. TFA $(2 \mathrm{ml})$ was added to the reaction mixture and stirred for $2 \mathrm{~h}$. The solvent was evaporated and residue was dried under high vacuum. The residue was passaged through preparative HPLC to remove excess 12. The obtained linear peptide 13 (17 mg, 72\%: HRMS (ESI) $\left.m / z:[\mathrm{M}+\mathrm{H}]^{+}\right)$ calcd for $\mathrm{C}_{49} \mathrm{H}_{54} \mathrm{~N}_{5} \mathrm{O}_{15} \mathrm{~S}$ 984.3332; found 984.3351) was dissolved in a mixture of DMF/DCM (1:1, 40 ml). HATU (9 mg, $0.023 \mathrm{mmol})$, HOAt (4 $\mu \mathrm{l}, 1 \mathrm{M}$ solution in DMF, $0.023 \mathrm{mmol})$, and NEt $3(10 \mu 1,0.07$ mmol) were added. The mixture was stirred for $24 \mathrm{~h}$ and solvent was evaporated under reduced pressure. The compound was purified using preparative HPLC to provide $14(9 \mathrm{mg}, 55 \%)$ as a white foam in 2.4:1 d.r. Crystallization from the HPLC eluent (MeCN/water) provided crystals of $\mathbf{1 4 b}$ suitable for X-ray crystallography. 14a: ${ }^{1} \mathbf{H}$ NMR $\left(500 \mathrm{MHz}\right.$, acetone- $\left.d_{6}\right) \delta 8.16(\mathrm{~d}, J=8.9 \mathrm{~Hz}, 2 \mathrm{H}), 7.92(\mathrm{~d}, J=8.9 \mathrm{~Hz}, 2 \mathrm{H})$, $7.58(\mathrm{~d}, J=6.9 \mathrm{~Hz}, 1 \mathrm{H}), 7.5-7.46(\mathrm{~m}, 2 \mathrm{H}), 7.41-7.27(\mathrm{~m}, 11 \mathrm{H}), 7.04-6.95(\mathrm{~m}, 3 \mathrm{H}), 6.84(\mathrm{~d}, J=8.7 \mathrm{~Hz}$, 2H), 6.73-6.67 (m, 3H), $6.35(\mathrm{~d}, J=7.0 \mathrm{~Hz}, 1 \mathrm{H}), 5.97(\mathrm{~m}, 1 \mathrm{H}), 5.40-5.33(\mathrm{~m}, 2 \mathrm{H}), 5.29(\mathrm{~d}, J=9.8 \mathrm{~Hz}$, 1H), 4.68-4.63 (m, 3H), 4.51 (q, $J=12.2 \mathrm{~Hz}, 3 \mathrm{H}), 4.32(\mathrm{dd}, J=6.8,3.2 \mathrm{~Hz}, 1 \mathrm{H}), 4.06-3.97$ (m, 3H), 3.89 (m, 1H), 3.79-3.71 (m, 4H), 3.39 (dd, $J=16.8,5.6 \mathrm{~Hz}, 1 \mathrm{H}), 3.30(\mathrm{dd}, J=14.1,5.6 \mathrm{~Hz}, 1 \mathrm{H}), 3.14$ (dd, $J=6.3,3.2 \mathrm{~Hz}, 1 \mathrm{H}), 0.77(\mathrm{~d}, J=6.3 \mathrm{~Hz}, 3 \mathrm{H}) .{ }^{13} \mathbf{C}$ NMR $\left(126 \mathrm{MHz}\right.$, acetone- $\left.d_{6}\right) \delta 171.3,169.2,168.6$, $167.3,158.1,156.6,149.9,146.4,138.9,138.5,132.4,130.6,130.3,129.1,128.7,128.3,128.0,127.7$, $127.6,127.5,127.5,123.9,119.0,117.2,115.5,109.9,80.3,79.1,74.8,74.1,70.4,65.0,62.6,59.3,55.9$, 52.3, 42.6, 35.4, 14.2. HRMS (ESI) $m / z:[\mathrm{M}+\mathrm{H}]^{+}$) calcd for $\mathrm{C}_{49} \mathrm{H}_{52} \mathrm{~N}_{5} \mathrm{O}_{14} \mathrm{~S} 966.3226$ found 966.3226. 14b: ${ }^{1}$ H NMR $\left(500 \mathrm{MHz}\right.$, acetone- $\left.d_{6}\right) \delta 7.87(\mathrm{~d}, J=8.9 \mathrm{~Hz}, 2 \mathrm{H}), 7.68(\mathrm{~m}, 1 \mathrm{H}), 7.54-7.50(\mathrm{~m}, 2 \mathrm{H}), 7.42-$ $7.35(\mathrm{~m}, 9 \mathrm{H}), 7.32-7.22(\mathrm{~m}, 4 \mathrm{H}), 7.14-7.07(\mathrm{~m}, 4 \mathrm{H}), 6.87(\mathrm{~d}, J=8.8 \mathrm{~Hz}, 2 \mathrm{H}), 6.52(\mathrm{~d}, J=6.7 \mathrm{~Hz}, 1 \mathrm{H})$, $5.98(\mathrm{~m}, 1 \mathrm{H}), 5.74(\mathrm{~d}, J=2.6 \mathrm{~Hz}, 1 \mathrm{H}), 5.39(\mathrm{dd}, J=5.4,1.6 \mathrm{~Hz}, 1 \mathrm{H}), 5.36(\mathrm{~m}, 1 \mathrm{H}), 5.24(\mathrm{~m}, 1 \mathrm{H}), 4.76(\mathrm{~m}$, $1 \mathrm{H}), 4.65-4.63(\mathrm{~m}, 3 \mathrm{H}), 4.55(\mathrm{~s}, 1 \mathrm{H}), 4.26-4.23(\mathrm{~m}, 1 \mathrm{H}), 3.99(\mathrm{dd}, J=5.7,1.1 \mathrm{~Hz}, 1 \mathrm{H}), 3.87$ (d, $J=7.0$ 
Hz, 1H), 3.74 (d, $J=3.5 \mathrm{~Hz}, 5 \mathrm{H}), 3.64(\mathrm{~m}, 1 \mathrm{H}), 3.44$ (dd, $J=16.5,5.4 \mathrm{~Hz}, 1 \mathrm{H}), 3.23(\mathrm{~m}, 1 \mathrm{H}), 0.86(\mathrm{~d}$, $J=6.3 \mathrm{~Hz}, 3 \mathrm{H}) .{ }^{13} \mathbf{C}$ NMR $\left(126 \mathrm{MHz}\right.$, acetone- $\left.d_{6}\right) \delta 171.0,168.6,168.4,167.3,159.1,157.8,149.8,146.6$, $139.0,130.7,130.1,129.7,128.7,128.5,128.2,128.1,127.7,127.5,127.5,123.8,119.0,117.4,115.5$, $84.3,80.4,74.9,74.6,70.7,65.8,65.2,63.4,62.7,61.2,56.4,54.6,53.0,43.2,35.9,14.6$. HRMS (ESI) $m / z:[\mathrm{M}+\mathrm{H}]^{+}$) calcd for $\mathrm{C}_{49} \mathrm{H}_{52} \mathrm{~N}_{5} \mathrm{O}_{14} \mathrm{~S} 966.3226$; found 966.3226 .

\section{Tyr(Bn)-tBu. HCl (16)}

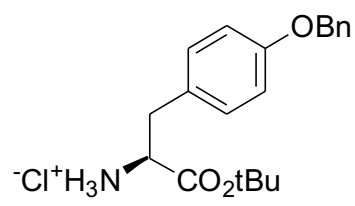

To a solution of $\mathrm{Tyr}(\mathrm{Bn})(5.0 \mathrm{~g}, 18.5 \mathrm{mmol})$ and $\mathrm{NaHCO}_{3}(3.0 \mathrm{~g}, 36 \mathrm{mmol})$ in $\mathrm{THF} /$ water $(1: 1,100 \mathrm{ml})$, $\mathrm{Boc}_{2} \mathrm{O}(4.8 \mathrm{~g}, 22 \mathrm{mmol})$ was added. The mixture was stirred for $3 \mathrm{~h}$ and extracted with diethyl ether (100 $\mathrm{ml})$. The aqueous phase was acidified to adjust the $\mathrm{pH}$ to 4 and extracted with EtOAc $(3 \times 100 \mathrm{ml})$. The combined EtOAc layers were washed with brine $(100 \mathrm{ml})$ and dried over magnesium sulfate. The solvent was evaporated and the residue was redissolved in THF (25 ml). tert-butyl 2,2,2-trichloroacetimidate ( $7.8 \mathrm{~g}, 36 \mathrm{mmol}$ ) was added to the mixture and stirred overnight. The solvent was evaporated and residue dissolved in EtOAc $(100 \mathrm{ml})$ then washed with saturated $\mathrm{NH}_{4} \mathrm{Cl}(100 \mathrm{ml})$. The organic layers were dried over magnesium sulfate, evaporated, and residue was dissolved in DCM (20 ml). TFA (5 ml) was added to the mixture and stirred for $1 \mathrm{~h}$ at room temperature. $1 \mathrm{~N} \mathrm{HCl}(50 \mathrm{ml})$ was added to the mixture and aqueous phase was extracted with DCM $(2 \times 20 \mathrm{ml})$. The aqueous phase was basified using $4 \mathrm{~N} \mathrm{NaOH}$ to adjust the $\mathrm{pH}$ to 10 at $0{ }^{\circ} \mathrm{C}$. The aqueous phase was extracted using EtOAc $(4 \times 50 \mathrm{ml})$ and combined organic layers were dried over magnesium sulfate. The solvent was evaporated and diethyl ether $(20 \mathrm{ml})$ was added. $\mathrm{HCl}(15 \mathrm{ml}, 1 \mathrm{M}$ in diethyl ether) was added to the mixture to precipitate the $\operatorname{Tyr}(\mathrm{Bn})$-tBu.HCl $16(4.0 \mathrm{~g}, 60 \%)$ as a white powder. ${ }^{1} \mathbf{H}$ NMR $\left(500 \mathrm{MHz}\right.$, DMSO- $\left.d_{6}\right) \delta 8.55(\mathrm{~s}, 3 \mathrm{H}), 7.42(\mathrm{~d}, J=8.4 \mathrm{~Hz}$, 
2H), $7.37(\mathrm{~m}, 2 \mathrm{H}), 7.30(\mathrm{~m}, 1 \mathrm{H}), 7.17(\mathrm{~d}, J=8.6 \mathrm{~Hz}, 2 \mathrm{H}), 6.96(\mathrm{~d}, J=8.5,2 \mathrm{H}), 5.09(\mathrm{~d}, J=2.9 \mathrm{~Hz}, 2 \mathrm{H})$, $4.05(\mathrm{~m}, 1 \mathrm{H}), 3.12$ (dd, $J=14.2,5.6 \mathrm{~Hz}, 1 \mathrm{H}), 2.93(\mathrm{dd}, J=14.1,8.2 \mathrm{~Hz}, 1 \mathrm{H}), 1.28$ (s, 9H). ${ }^{13} \mathbf{C}$ NMR $(126$ MHz, DMSO- $\left.d_{6}\right) \delta 168.5,157.9,137.6,131.1,128.9,128.2,128.0,127.3,115.2,83.1,69.5,54.0,35.7$, 27.9, 27.8. HRMS (ESI) $m / z$ : $[\mathrm{M}+\mathrm{H}]^{+}$) calcd for $\mathrm{C}_{20} \mathrm{H}_{26} \mathrm{NO}_{3}$ 328.1907; found 328.1909.

\section{$C$-terminal macrocycle (17)}

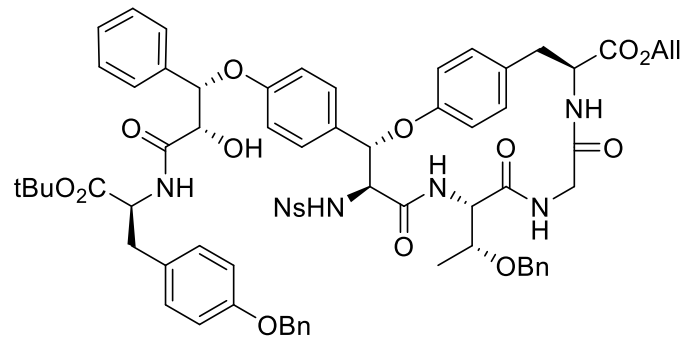

To a stirred solution of diol $14(35 \mathrm{mg}, 0.036 \mathrm{mmol})$ and TEMPO $(6 \mathrm{mg}, 0.038 \mathrm{mmol})$ in acetone $(0.7$ $\mathrm{ml})$ at $0{ }^{\circ} \mathrm{C}, \mathrm{KBr}(0.5 \mathrm{mg}, 10 \mathrm{~mol} \%, 0.004 \mathrm{mmol})$ and $5 \%$ aqueous $\mathrm{NaHCO}_{3}$ solution $(0.1 \mathrm{ml})$ were added. $9 \% \mathrm{NaOCl}(0.2 \mathrm{ml})$ was added and the mixture was stirred for $2 \mathrm{~h}$ at $0{ }^{\circ} \mathrm{C}$. A solution of $5 \%$ aqueous $\mathrm{NaHCO}_{3}(0.2 \mathrm{ml}, 0.072 \mathrm{mmol})$ was added to quench the reaction and the solvent was evaporated under reduced pressure. The compound was purified using HPLC to give the free carboxylic acid 15 (25 mg, $70 \%$ ) as a white solid. HRMS (ESI) $m / z:[\mathrm{M}+\mathrm{H}]^{+}$) calcd for $\mathrm{C}_{49} \mathrm{H}_{52} \mathrm{~N}_{5} \mathrm{O}_{14} \mathrm{~S} 980.3019$; found 980.3020 . To a solution of carboxylic acid 15 (20 mg, $0.02 \mathrm{mmol})$ in DMF $(1 \mathrm{ml})$, EDC.Cl (4 mg, $0.022 \mathrm{mmol})$, HOBt (3 mg, $0.022 \mathrm{mmol})$, Tyr(Bn)-tBu 16 ( $8 \mathrm{mg}, 0.022 \mathrm{mmol})$, and NEt 3 ( $3 \mu \mathrm{l}, 0.022 \mathrm{mmol})$ were added. The mixture was stirred overnight and solvent was evaporated under reduced pressure. The compound was purified using preparative HPLC to give compound 17 as a white solid (20 $\mathrm{mg}, 80 \%) .{ }^{1} \mathbf{H}$ NMR (600 MHz, acetone- $\left.d_{6}\right) \delta 8.26-8.20(\mathrm{~m}, 1 \mathrm{H}), 8.16-8.13(\mathrm{~m}, 2 \mathrm{H}), 7.93-7.89(\mathrm{~m}, 2 \mathrm{H}), 7.86(\mathrm{~m}, 1 \mathrm{H})$, $7.51(\mathrm{~d}, J=7.9 \mathrm{~Hz}, 1 \mathrm{H}), 7.48(\mathrm{~d}, J=7.0,2 \mathrm{H}), 7.47-7.43(\mathrm{~m}, 4 \mathrm{H}), 7.41-7.34(\mathrm{~m}, 8 \mathrm{H}), 7.34-7.29(\mathrm{~m}, 8 \mathrm{H})$, 7.29-7.21 (m, 4H), 7.10-7.04 (m, 1.5), 7.02-6.91 (m, 4H), 6.87 (m, 1H), 6.86-6.83 (m, 2H), 6.81-6.75 (m, 2.5H), 6.72-6.65 (m, 3H), 6.65-6.61 (m, 3H), $6.33(\mathrm{~m}, 0.5 \mathrm{H}), 5.94(\mathrm{~m}, 1.5 \mathrm{H}), 5.81(\mathrm{~m}, 0.5 \mathrm{H}), 5.77$ 
$(\mathrm{m}, 1 \mathrm{H}), 5.75(\mathrm{~m}, 1 \mathrm{H}), 5.39-5.31(\mathrm{~m}, 1.5 \mathrm{H}), 5.28(\mathrm{~d}, J=9.9,1 \mathrm{H}), 5.21(\mathrm{~m}, 1.5 \mathrm{H}), 5.11(\mathrm{~s}, 0.5 \mathrm{H}), 5.08$ $(\mathrm{s}, 0.5 \mathrm{H}), 5.06(\mathrm{~m}, 3 \mathrm{H}), 4.78(\mathrm{~m}, 1 \mathrm{H}), 4.75(\mathrm{~m}, 0.5 \mathrm{H}), 4.67-4.59(\mathrm{~m}, 5 \mathrm{H}), 4.57(\mathrm{~m}, 0.5 \mathrm{H}), 4.55-4.45(\mathrm{~m}$, $3 \mathrm{H}), 4.40(\mathrm{~m}, 0.5 \mathrm{H}), 4.30(\mathrm{~m}, 1 \mathrm{H}), 4.23(\mathrm{~m}, 0.5 \mathrm{H}), 3.86(\mathrm{~m}, 1.5 \mathrm{H}), 3.64 \mathrm{~m}, 0.5 \mathrm{H}), 3.48-3.34(\mathrm{~m}, 2 \mathrm{H})$, $3.30(\mathrm{~m}, 1.5 \mathrm{H}), 3.20(\mathrm{dd}, J=14.5,5.5 \mathrm{~Hz}, 0.5 \mathrm{H}), 3.15(\mathrm{dd}, J=6.4,3.1 \mathrm{~Hz}, 1 \mathrm{H}), 2.95-2.87(\mathrm{~m}, 2 \mathrm{H}), 2.69$ (m, 1H), 2.66-2.58 (m, 2H), $1.36(\mathrm{~d}, J=1.9 \mathrm{~Hz}, 15 \mathrm{H}), 0.85(\mathrm{~d}, J=6.3,1.5 \mathrm{H}), 0.76(\mathrm{~d}, J=6.0 \mathrm{~Hz}, 3 \mathrm{H}) .{ }^{13} \mathrm{C}$ NMR $\left(151 \mathrm{MHz}\right.$, acetone- $\left.d_{6}\right) \delta 171.2,170.9,169.8,169.3,169.2,169.0,169.0,168.4,168.2,168.2$, $167.2,160.0,159.1,157.7,157.6,157.2,156.6,150.8,149.8,146.6,146.4,138.4,137.6,136.4,136.3$, $132.4,130.8,130.5,130.5,130.3,130.1,129.6,129.2,129.1,128.6,128.5,128.4,128.3,128.3,128.2$, $128.1,128.0,127.8,127.7,127.6,127.5,127.5,127.5,123.9,123.8,119.0,117.4,117.2,115.4,114.7$, $114.6,114.4,109.9,84.2,81.4,80.4,79.0,74.6,74.1,74.0,70.7,70.4,69.4,65.2,65.0,61.2,59.3,56.4$, 56.4, 55.8, 52.9, 52.8, 52.7, 52.1, 43.0, 42.5, 36.9, 35.9, 35.3, 29.6, 29.5, 27.2, 27.2, 14.6, 14.2. HRMS (ESI) $m / z:[\mathrm{M}+\mathrm{H}]^{+}$) calcd for $\mathrm{C}_{69} \mathrm{H}_{73} \mathrm{~N}_{6} \mathrm{O}_{17} \mathrm{~S}$ 1289.4747; found 1289.4748.

\section{Denosylated peptide (18)}

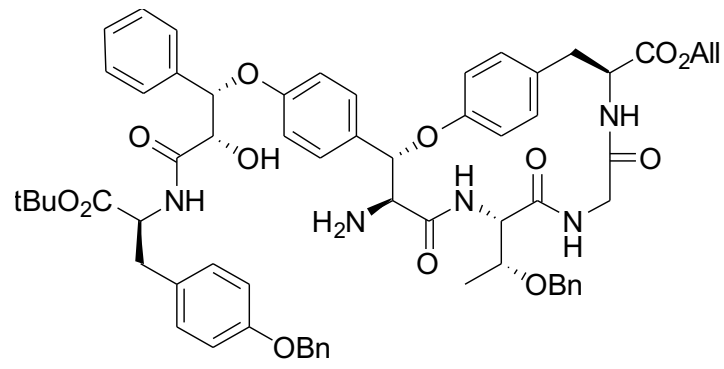

Compound $17(10 \mathrm{mg}, 0.007 \mathrm{mmol})$ was dissolved in $[\mathrm{Bmim}]-\left[\mathrm{BF}_{4}\right](150 \mu \mathrm{l})$ and $\mathrm{NEt}_{3}(45 \mu \mathrm{l}, 0.34$ mmol), mercaptoacetic acid $(24 \mu 1,0.34 \mathrm{mmol})$ were added. The reaction mixture was stirred for $4 \mathrm{~h}$. The mixture was purified by preparative HPLC to afford the amine $\mathbf{1 8}(5.0 \mathrm{mg}, 75 \%)$ as a white solid. HRMS (ESI) $m / z:[\mathrm{M}+\mathrm{H}]^{+}$) calcd for $\mathrm{C}_{63} \mathrm{H}_{70} \mathrm{~N}_{5} \mathrm{O}_{13}$ 1104.4965; found 1104.4966. 


\section{Bicyclic peptide (19)}

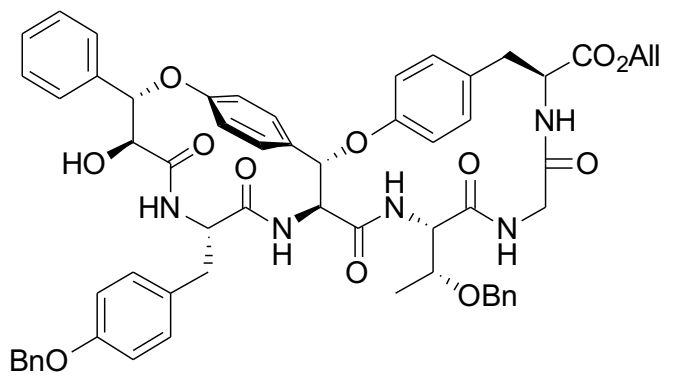

Amine $18(5.0 \mathrm{mg}, 0.004 \mathrm{mmol})$ was dissolved in a solution of TFA in DCM $(50 \%, 1 \mathrm{ml})$ and the mixture was stirred for $1 \mathrm{~h}$. The solvent was evaporated and dried under high vacuum. The residue was dissolved in a mixture of DMF/DCM $(1: 10,10 \mathrm{ml})$ and HATU $(1.5 \mathrm{mg}, 0.0044 \mathrm{mmol})$, HOAt $(5 \mu \mathrm{l}$ of $1 \mathrm{M}$ solution in DMF, $0.0044 \mathrm{mmol})$ and $\mathrm{NEt}_{3}(0.012 \mathrm{mmol})$ were added. The mixture was stirred overnight then the solvent was evaporated under reduced pressure. The product was purified by HPLC to give the bicyclic compound 19 (1.0 mg, 15\%). Retention time: 45.36 minutes. HRMS (ESI) $m / z:[\mathrm{M}+\mathrm{H}]^{+}$) calcd for $\mathrm{C}_{59} \mathrm{H}_{60} \mathrm{~N}_{5} \mathrm{O}_{12}$ 1030.4233; found 1030.4230. The cyclodimer was also isolated (1.7 mg, 25\%), HRMS (ESI) $m / z:[\mathrm{M}+\mathrm{H}]^{+2}$ ) calcd for $\mathrm{C}_{118} \mathrm{H}_{120} \mathrm{~N}_{10} \mathrm{O}_{24}$ 1030.9250; found 1030.9242 .

\section{Protected asperipin-2a (20)}

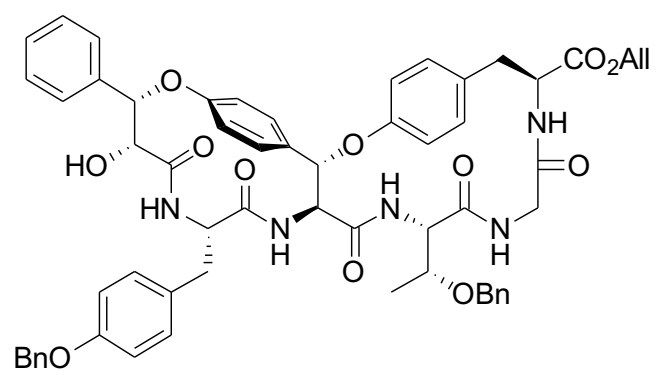

Compound 19 (2.4 mg, $2.3 \mu \mathrm{mol})$ was dissolved in dry THF (75 $\mu \mathrm{l})$ and pyridine $(10 \%$ pyridine in THF solution, $7 \mu \mathrm{l}, 7 \mu \mathrm{mol})$ was added at $-20^{\circ} \mathrm{C}$. Trifluoromethanesulfonic anhydride ( $10 \%$ trifluoromethanesulfonic anhydride in dry THF solution, $14.4 \mu \mathrm{l}, 17 \mu \mathrm{mol}$ ) was added and the mixture was stirred at -10 
${ }^{\circ} \mathrm{C}$ for $2 \mathrm{~h}$. The solvent was evaporated under reduced pressure and dried under high vacuum for $10 \mathrm{~h}$. The residue was subsequently dissolved in DMF $(75 \mu \mathrm{l})$ and $\mathrm{KNO}_{2}(1.1 \mathrm{mg}, 12 \mu \mathrm{mol})$ was added at room temperature and the mixture was stirred overnight. The solvent was evaporated under a stream of nitrogen and the residue was purified by HPLC to give compound $\mathbf{2 0}$ as a white foam $(1.0 \mathrm{mg}, 41 \%, 70 \%$ based of recovered starting material). HRMS (ESI) $m / z$ : $[\mathrm{M}+\mathrm{H}]^{+}$) calcd for $\mathrm{C}_{59} \mathrm{H}_{60} \mathrm{~N}_{5} \mathrm{O}_{12}$ 1030.4233; found 1030.4230. Starting material was recovered $(0.7 \mathrm{mg})$.

\section{Boc-Thr(All)-OH (S2)}

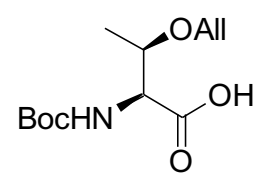

Sodium hydride (2.44 g of a $60 \%$ oil dispersion, $1.46 \mathrm{~g}, 0.061 \mathrm{~mol}$ ) was suspended in $20 \mathrm{~mL}$ of DMF and cooled to $0{ }^{\circ} \mathrm{C}$. Boc-Thr-OH $(5.26 \mathrm{~g}, 0.024 \mathrm{~mol})$ was dissolved in $40 \mathrm{~mL}$ of DMF and the resulting solution was added drop-wise to the $\mathrm{NaH}$ solution over a period of 30 minutes. Allyl bromide $(2.0 \mathrm{~mL}$, $0.024 \mathrm{~mol}$ ) was added and the flask contents warmed to room temperature and stirred for 3 hours. The reaction was quenched by addition of water $(12 \mathrm{ml})$. The solvents were then removed on the rotary evaporator and the residue dissolved in water $(40 \mathrm{~mL})$, which was washed with ethyl acetate $(2 \times 25 \mathrm{ml})$. The aqueous phase was acidified to $\mathrm{pH} 2$ with the addition of $6 \mathrm{~N} \mathrm{HCl}$ and extracted with ethyl acetate $(3 \times 40 \mathrm{ml})$. The organic phases were combined and dried over anhydrous magnesium sulfate. After filtration, the solvent was evaporated to yield $\mathbf{S} 2$ as a viscous oil $(4.8 \mathrm{~g}, 82 \%)$ which was used in the next reactions without further purification. ${ }^{1} \mathbf{H} \mathbf{~ N M R}\left(500 \mathrm{MHz}, \mathrm{CDCl}_{3}\right) \delta 5.85(\mathrm{ddt}, J=16.4,10.8,5.7 \mathrm{~Hz}$, 1H), $5.32(\mathrm{~d}, J=8.8 \mathrm{~Hz}, 1 \mathrm{H}), 5.26(\mathrm{~m}, 1 \mathrm{H}), 5.16(\mathrm{~m}, 1 \mathrm{H}), 4.34(\mathrm{dd}, J=8.9,2.6 \mathrm{~Hz}, 1 \mathrm{H}), 4.13$ (dt, $J=7.7$, $3.9 \mathrm{~Hz}, 1 \mathrm{H}), 4.09$ (dd, $J=12.8,5.6 \mathrm{~Hz}, 1 \mathrm{H}), 3.96(\mathrm{dd}, J=12.7,5.7 \mathrm{~Hz}, 1 \mathrm{H}), 1.46$ (s, 9H), 1.23 (d, $J=6.3$ $\mathrm{Hz}, 3 \mathrm{H})$. HRMS (ESI) $m / z:[\mathrm{M}+\mathrm{H}]^{+}$) calcd for $\mathrm{C}_{12} \mathrm{H}_{22} \mathrm{NO}_{5} 260.1492$; found 260.1495. 


\section{Boc-Thr(All)-Gly-OtBu (S3)}

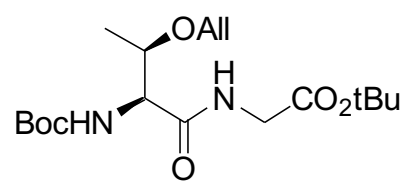

Boc-Thr(OAll)-OH S2 (4.0 g, $13 \mathrm{mmol})$, EDC.Cl (2.42 g, $15.6 \mathrm{mmol}, 1.2 \mathrm{eq})$ and HOBt (2.1 g, 15.6 mmol, $1.2 \mathrm{eq})$ were dissolved in $\operatorname{DMF}(50 \mathrm{ml})$ at $0{ }^{\circ} \mathrm{C} . \mathrm{Gly}-\mathrm{O} t \mathrm{Bu}(2.6 \mathrm{~g}, 15.6 \mathrm{mmol}, 1.2 \mathrm{eq})$ and $\mathrm{NEt}_{3}$ (4.0 ml, $28.6 \mathrm{mmol}, 2.2 \mathrm{eq})$ were added and the mixture was stirred overnight. Water $(100 \mathrm{ml})$ was added and the mixture was extracted with EtOAc $(3 \times 100 \mathrm{ml})$. The combined organic phase was washed with brine and dried over magnesium sulfate. The solvent was evaporated under vacuum and the crude was purified using column chromatography (EtOAc:Hex, 25\%) to yield Boc-Thr(All)-Gly-OtBu dipeptide S3 as a clear oil (4.30 g, 90\%). ${ }^{1} \mathbf{H}$ NMR $\left(600 \mathrm{MHz}, \mathrm{CDCl}_{3}\right) \delta 7.00$ (s, 1H), 5.88 (ddt, $J=16.3,10.8,5.6$ $\mathrm{Hz}, 1 \mathrm{H}), 5.53-5.43(\mathrm{~m}, 1 \mathrm{H}), 5.26(\mathrm{dt}, J=17.2,1.6 \mathrm{~Hz}, 1 \mathrm{H}), 5.15(\mathrm{dt}, J=10.4,1.4 \mathrm{~Hz}, 1 \mathrm{H}), 4.23(\mathrm{~m}, 1 \mathrm{H})$, 4.13-4.02 (m, 4H), $3.93(\mathrm{dd}, J=5.2,1.1 \mathrm{~Hz}, 2 \mathrm{H}), 1.50-1.37$ (m, 18H), $1.14(\mathrm{~d}, J=6.4 \mathrm{~Hz}, 3 \mathrm{H}) .{ }^{13} \mathbf{C}$ NMR $\left(151 \mathrm{MHz} \mathrm{CDCl}_{3}\right) \delta 170.0,168.5,155.8,134.5,117.1,82.2,80.0,74.2,70.4,57.5,42.1,28.3,28.0$, 15.4. HRMS (ESI) $m / z:[\mathrm{M}+\mathrm{H}]^{+}$) calcd for $\mathrm{C}_{18} \mathrm{H}_{33} \mathrm{~N}_{2} \mathrm{O}_{6} 373.2333$; found 373.2334.

\section{Thr(All)-Gly-OtBu (21)}

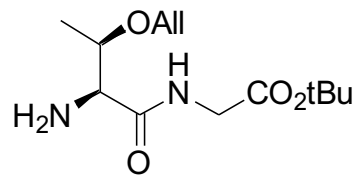

Boc-Thr(All)-Gly-OtBu dipeptide S3 (4.0 g, $11.3 \mathrm{mmol}$ ) was dissolved in 20\% trifluoroacetic acid in $\operatorname{DCM}(20 \mathrm{ml})$ at $0{ }^{\circ} \mathrm{C}$. The mixture was stirred for $40 \mathrm{~min}$ at room temperature, before adjusting $\mathrm{pH}$ to 11 with $2 \mathrm{M} \mathrm{NaOH}$. The aqueous phase was extracted with DCM and dried over magnesium sulfate. The solvent was evaporated and residue was purified using column chromatography $(10 \% \mathrm{MeOH} / \mathrm{DCM})$ to give the product 21 as a yellow oil $(2.50 \mathrm{~g}, 80 \%) .{ }^{1} \mathbf{H} \mathbf{N M R}\left(600 \mathrm{MHz}, \mathrm{CDCl}_{3}\right) \delta 7.90(\mathrm{t}, J=5.5 \mathrm{~Hz}, 1 \mathrm{H})$, 
5.81 (ddt, $J=17.1,10.2,5.6 \mathrm{~Hz}, 1 \mathrm{H}), 5.18(\mathrm{dd}, J=17.2,1.7 \mathrm{~Hz}, 1 \mathrm{H}), 5.08(\mathrm{dd}, J=10.4,1.5 \mathrm{~Hz}, 1 \mathrm{H}), 4.03$ (m, 1H), $3.99(\mathrm{~m}, 1 \mathrm{H}), 3.97(\mathrm{~m}, 1 \mathrm{H}), 3.94(\mathrm{~d}, J=5.7 \mathrm{~Hz}, 1 \mathrm{H}), 3.91-3.80(\mathrm{~m}, 2 \mathrm{H}), 1.42(\mathrm{~s}, 9 \mathrm{H}), 1.16(\mathrm{~d}$, $J=6.4 \mathrm{~Hz}, 3 \mathrm{H}) .{ }^{13} \mathbf{C}$ NMR $\left(151 \mathrm{MHz}, \mathrm{CDCl}_{3}\right) \delta 173.5,169.0,134.9,116.6,82.0,74.6,70.1,59.1,41.8$, 28.0, 16.8. HRMS (ESI) $m / z:[\mathrm{M}+\mathrm{H}]^{+}$) calcd for $\mathrm{C}_{13} \mathrm{H}_{25} \mathrm{~N}_{2} \mathrm{O}_{4} 273.1809$; found 273.1805.

\section{Tripeptide ether (S4)}

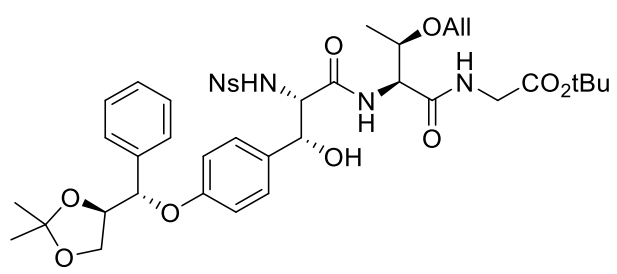

To a solution of $\beta$-hydroxytyrosine derivative 8 (73 $\mathrm{mg}, 0.14 \mathrm{mmol})$ in DMF, (1 ml) and EDC.Cl (30 $\mathrm{mg}, 0.157 \mathrm{mmol}, 1.1 \mathrm{eq})$ and $\mathrm{HOBt}(21 \mathrm{mg}, 0.157 \mathrm{mmol} 1.1 \mathrm{eq})$ were added and the mixture was stirred at room temperature for $5 \mathrm{~min}$. Thr(All)-Gly-OtBu 21 (78 mg, $0.286 \mathrm{mmol}, 2 \mathrm{eq})$ and $\mathrm{NEt}_{3}(41 \mu 1,0.286$ mmol, 2 eq $)$ were added and the reaction mixture was stirred overnight. Water $(2 \mathrm{ml})$ was the added and the mixture was extracted with EtOAc $(3 \times 5 \mathrm{ml})$. The extracts were washed with $1 \mathrm{~N} \mathrm{HCl}(10 \mathrm{ml})$, $\mathrm{NaHCO}_{3}(10 \mathrm{ml})$ brine $(10 \mathrm{ml})$ and dried over magnesium sulfate. The compound was purified using column chromatography (50\% EtOAc/Hex) to give product $\mathbf{S 4}$ as a white foam $(86 \mathrm{mg}, 80 \%) .{ }^{1} \mathbf{H} \mathbf{~ N M R}$ $\left(600 \mathrm{MHz}, \mathrm{CDCl}_{3}\right) \delta 8.06$ (d, $\left.J=8.8 \mathrm{~Hz}, 2 \mathrm{H}\right), 7.68$ (d, $\left.J=8.8 \mathrm{~Hz}, 2 \mathrm{H}\right), 7.46$ (d, $\left.J=7.6 \mathrm{~Hz}, 1 \mathrm{H}\right), 7.35-7.29$ (m, 4H), 7.28-7.23 (m, 1H), $7.18(\mathrm{t}, J=5.5 \mathrm{~Hz}, 1 \mathrm{H}), 6.96(\mathrm{~d}, J=8.8 \mathrm{~Hz}, 2 \mathrm{H}), 6.62(\mathrm{~d}, J=8.8 \mathrm{~Hz}, 2 \mathrm{H}), 6.09$ (d, $J=6.5 \mathrm{~Hz}, 1 \mathrm{H}), 5.76$ (ddt, $J=17.2,10.4,5.7 \mathrm{~Hz}, 1 \mathrm{H}), 5.22-5.14(\mathrm{~m}, 1 \mathrm{H}), 5.12-5.05$ (m, 2H), 5.00 (d, $J=6.2 \mathrm{~Hz}, 1 \mathrm{H}), 4.45(\mathrm{dd}, J=7.7,2.9 \mathrm{~Hz}, 1 \mathrm{H}), 4.35(\mathrm{~m}, 1 \mathrm{H}), 4.15$ (dd, $J=8.8,5.4 \mathrm{~Hz}, 1 \mathrm{H}), 4.08(\mathrm{~m}, 1 \mathrm{H})$, $3.98(\mathrm{~m}, 1 \mathrm{H}), 3.95-3.91(\mathrm{~m}, 3 \mathrm{H}), 3.920(\mathrm{~m}, 1 \mathrm{H}), 3.88-3.78(\mathrm{~m}, 2 \mathrm{H}), 1.42(\mathrm{~s}, 3 \mathrm{H}), 1.39(\mathrm{~s}, 9 \mathrm{H}), 1.32(\mathrm{~s}$, 3H), $0.99(\mathrm{~d}, J=6.4 \mathrm{~Hz}, 3 \mathrm{H}) .{ }^{13} \mathbf{C}$ NMR $\left(151 \mathrm{MHz}, \mathrm{CDCl}_{3}\right) \delta 169.3,169.1,168.5,157.8,149.9,144.3$, $137.8,134.1,131.1,128.6,128.4,128.3,127.0,126.8,124.0,117.5,116.1,109.9,82.3,80.6,79.0,73.3$, 
72.8, 70.6, 66.2, 61.9, 56.9, 42.1, 27.9, 26.6, 25.3, 15.6. HRMS (ESI) $m / z:[\mathrm{M}+\mathrm{H}]^{+}$) calcd for $\mathrm{C}_{40} \mathrm{H}_{51} \mathrm{~N}_{4} \mathrm{O}_{13} \mathrm{~S}$ 827.3168; found 827.3166.

\section{Tripeptide aziridine (22)}

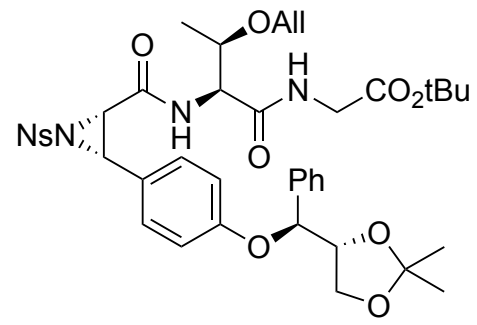

To a flame dried 2-necked RB flask, tripeptide ether $\mathbf{S 4}(41 \mathrm{mg}, 0.05 \mathrm{mmol})$ and triphenylphosphine (16 $\mathrm{mg}, 0.06 \mathrm{mmol})$ were dissolved in THF $(15 \mu \mathrm{l})$ and sonicated for $5 \mathrm{~min}$. DIAD $(12 \mu \mathrm{l}, 0.06 \mathrm{mmol})$ was added and the mixture was stirred for 45 min. The compound was directly subjected to column chromatography (EtOAc/Hex, 25-75\%) to give aziridine 22 (36 mg, 90\%) as a white solid. ${ }^{1} \mathbf{H}$ NMR $\left(500 \mathrm{MHz}, \mathrm{CDCl}_{3}\right) \delta 8.43(\mathrm{~d}, J=8.9 \mathrm{~Hz}, 2 \mathrm{H}), 8.28-8.23(\mathrm{~m}, 2 \mathrm{H}), 7.36-7.22(\mathrm{~m}, 5 \mathrm{H}), 7.05(\mathrm{~d}, J=8.6 \mathrm{~Hz}$, 2H), $6.81(\mathrm{~d}, J=6.4 \mathrm{~Hz}, 1 \mathrm{H}), 6.79-6.72(\mathrm{~m}, 3 \mathrm{H}), 5.81(\mathrm{~m}, 1 \mathrm{H}), 5.23(\mathrm{~m}, 1 \mathrm{H}), 5.17$ (dt, $J=10.4,1.4 \mathrm{~Hz}$, 1H), $5.00(\mathrm{~d}, J=6.2 \mathrm{~Hz}, 1 \mathrm{H}), 4.34(\mathrm{~m}, 1 \mathrm{H}), 4.26$ (d, $J=7.8 \mathrm{~Hz}, 1 \mathrm{H}), 4.19$ (dd, $J=6.4,3.2 \mathrm{~Hz}, 1 \mathrm{H}), 4.16-$ $4.03(\mathrm{~m}, 2 \mathrm{H}), 3.95-3.88(\mathrm{~m}, 2 \mathrm{H}), 3.87-3.76(\mathrm{~m}, 2 \mathrm{H}), 3.67(\mathrm{~d}, J=7.8 \mathrm{~Hz}, 1 \mathrm{H}), 3.31$ (dd, $J=6.4,3.2 \mathrm{~Hz}$, 1H), $1.47(\mathrm{~s}, 9 \mathrm{H}), 1.44(\mathrm{~s}, 3 \mathrm{H}), 1.33(\mathrm{~s}, 3 \mathrm{H}), 0.11(\mathrm{~d}, J=6.4 \mathrm{~Hz}, 3 \mathrm{H}) .{ }^{13} \mathbf{C}$ NMR $\left(126 \mathrm{MHz}, \mathrm{CDCl}_{3}\right) \delta$ $168.2,168.1,162.8,158.3,151.0,142.8,137.7,134.1,129.4,128.9,128.6,128.3,126.6,124.8,123.0$, 117.3, 116.0, 110.0, 82.4, 80.3, 79.0, 73.0, 70.1, 66.1, 55.1, 46.1, 45.3, 42.0, 28.0, 26.6, 25.3, 13.5. HRMS (ESI) $m / z$ : $[\mathrm{M}+\mathrm{H}]^{+}$) calcd for $\mathrm{C}_{40} \mathrm{H}_{49} \mathrm{~N}_{4} \mathrm{O}_{12} \mathrm{~S}$ 809.3062; found 809.3061. 


\section{Tripeptide bis-ether (23)}

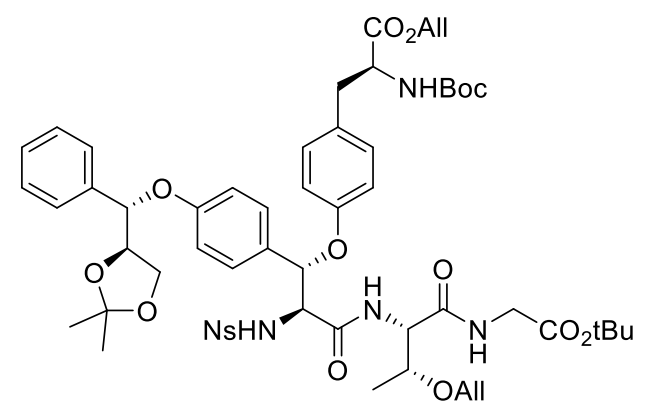

To a flame dried 2-neck RB flask under argon, aziridine 22 (18 mg, $0.023 \mathrm{mmol})$ was dissolved in DCM $(1 \mathrm{ml})$ at $-78^{\circ} \mathrm{C} . \mathrm{BF}_{3} . \mathrm{OEt}_{2}(8 \mu 1,0.012 \mathrm{mmol})$ was added followed by addition of a solution of Boc-TyrOAll 12 (75 mg, $0.234 \mathrm{mmol}, 10 \mathrm{eq})$ in DCM $(1 \mathrm{ml})$. The mixture was stirred for $-78^{\circ} \mathrm{C}$ for $10 \mathrm{~h}$ then overnight at $-20{ }^{\circ} \mathrm{C}$. Saturated $\mathrm{NaHCO}_{3}(5 \mathrm{ml})$ was added to the reaction mixture and extracted with EtOAc $(3 \times 5 \mathrm{ml})$. The combined organic layer was washed with brine and dried over magnesium sulfate. The solvent was evaporated and crude product was subjected to the column chromatography $(20 \%-95 \%$ EtOAc/Hexane) to give the major isomer 23a as a white foam $(14.0 \mathrm{mg})$ and a mixed fraction containing 23a and 23b (7.1 mg), total yield 92\%, 3:1 d.r. 23a ${ }^{1} \mathbf{H}$ NMR $\left(500 \mathrm{MHz}, \mathrm{CDCl}_{3}\right) \delta 8.17(\mathrm{~d}, J=8.9 \mathrm{~Hz}$, 2H), 7.88-7.83 (m, 2H), 7.41-7.29 (m, 5H), $7.20(\mathrm{~d}, J=6.9 \mathrm{~Hz}, 1 \mathrm{H}), 7.05(\mathrm{~d}, J=8.6 \mathrm{~Hz}, 2 \mathrm{H}), 6.99(\mathrm{t}, J=5.3$ $\mathrm{Hz}, 1 \mathrm{H}), 6.86(\mathrm{~d}, J=8.1 \mathrm{~Hz}, 2 \mathrm{H}), 6.75(\mathrm{~d}, J=8.7 \mathrm{~Hz}, 2 \mathrm{H}), 6.51(\mathrm{~d}, J=8.2 \mathrm{~Hz}, 2 \mathrm{H}), 5.95-5.71(\mathrm{~m}, 2 \mathrm{H}), 5.40$ $(\mathrm{d}, J=5.6 \mathrm{~Hz}, 1 \mathrm{H}), 5.31-5.23(\mathrm{~m}, 2 \mathrm{H}), 5.23-5.15(\mathrm{~m}, 2 \mathrm{H}), 5.01(\mathrm{~d}, J=6.1 \mathrm{~Hz}, 1 \mathrm{H}), 4.95(\mathrm{~d}, J=8.4 \mathrm{~Hz}$, 1H), 4.59-4.52 (m, 2H), $4.48(\mathrm{~d}, J=7.5 \mathrm{~Hz}, 1 \mathrm{H}), 4.41-4.32(\mathrm{~m}, 2 \mathrm{H}), 4.28(\mathrm{~d}, J=6.0 \mathrm{~Hz}, 1 \mathrm{H}), 4.15(\mathrm{dd}$, $J=8.7,5.4 \mathrm{~Hz}, 1 \mathrm{H}), 4.08(\mathrm{dd}, J=8.7,6.4 \mathrm{~Hz}, 1 \mathrm{H}), 4.02(\mathrm{~m}, 1 \mathrm{H}), 3.90(\mathrm{~m}, 1 \mathrm{H}), 3.82(\mathrm{dd}, J=12.0,5.5 \mathrm{~Hz}$, 2H), 3.00-2.85 (m, 2H), $1.46(\mathrm{~s}, 9 \mathrm{H}), 1.44(\mathrm{~s}, 3 \mathrm{H}), 1.40(\mathrm{~s}, 9 \mathrm{H}), 1.34(\mathrm{~s}, 3 \mathrm{H}), 0.92(\mathrm{~d}, J=6.4 \mathrm{~Hz}, 3 \mathrm{H})$. ${ }^{13} \mathrm{C}$ NMR $\left(126 \mathrm{MHz}, \mathrm{CDCl}_{3}\right) \delta 171.5,168.8,168.3,168.1,158.4,155.4,155.0,150.1,145.0,137.8$, $134.3,131.4,130.4,129.5,128.7,128.5,128.4,127.8,127.6,126.7,124.1,118.9,117.5,116.5,115.7$, $110.0,82.2,80.7,79.9,79.0,78.4,77.0,76.8,73.0,70.4,66.1,65.9,61.4,56.7,54.4,42.0,37.3,28.3$, 28.0, 26.6, 25.3, 15.4. HRMS (ESI) $m / z:[\mathrm{M}+\mathrm{H}]^{+}$) calcd for $\mathrm{C}_{57} \mathrm{H}_{72} \mathrm{~N}_{5} \mathrm{O}_{17} \mathrm{~S} 1130.4638$; found 1130.4639. 


\section{C-terminal macrocycle diol (24)}

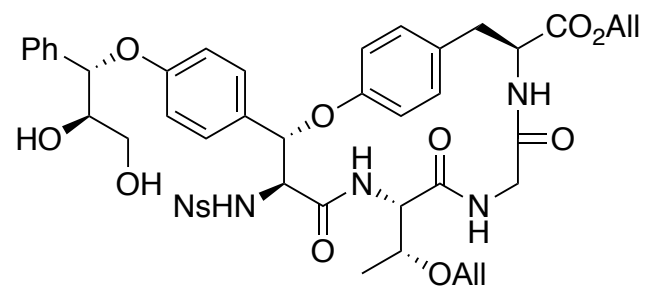

Compound 23a (24 mg, $0.021 \mathrm{mmol})$ was dissolved in a mixture of TFA in DCM $(50 \%, 2 \mathrm{ml})$ and stirred for $2 \mathrm{~h}$. The solvent was evaporated and the residue was dried under vacuum. The crude linear peptide was dissolved in a mixture of DMF/DCM (1:1, $40 \mathrm{ml})$. HATU (9.0 mg, $0.023 \mathrm{mmol})$, HOAt (4 $\mu$ l, $1 \mathrm{M}$ solution in DMF, $0.023 \mathrm{mmol})$, and $\mathrm{NEt}_{3}(10 \mu \mathrm{l}, 0.07 \mathrm{mmol})$ were added. The mixture was stirred for 24 $\mathrm{h}$ then concentrated under reduced pressure. Water $(30 \mathrm{ml})$ was added and the mixture extracted with EtOAc $(3 \times 30 \mathrm{ml})$. The combined organic layer was washed with saturated $\mathrm{NaHCO}_{3}(50 \mathrm{ml}), 1 \mathrm{~N} \mathrm{HCl}$ $(50 \mathrm{ml})$, brine $(50 \mathrm{ml})$, and dried over magnesium sulfate. The solvent was evaporated and the residue was purified using column chromatography (EtOAc/Hex, 40-100\%) to give the compound 24 (11 $\mathrm{mg}$, $60 \%)$ as a white foam. ${ }^{1} \mathbf{H}$ NMR $\left(500 \mathrm{MHz}\right.$, Acetone- $\left.d_{6}\right) \delta 8.31(\mathrm{~d}, J=8.8 \mathrm{~Hz}, 2 \mathrm{H}), 7.96(\mathrm{~d}, J=8.9 \mathrm{~Hz}$, 1H), 7.70-7.62 (m, 1H), 7.52-7.45 (m, 2H), 7.33 (dd, J=8.0, 5.5 Hz, 4H), 7.24 (d, J=7.5 Hz, 1H), 7.13 (s, 1H), 7.02-6.94 (m, 2H), $6.84(\mathrm{~d}, J=8.7 \mathrm{~Hz}, 2 \mathrm{H}), 6.73-6.65(\mathrm{~m}, 2 \mathrm{H}), 6.50(\mathrm{~d}, J=6.9 \mathrm{~Hz}, 1 \mathrm{H}), 5.95(\mathrm{ddt}$, $J=17.4,10.7,5.4 \mathrm{~Hz}, 1 \mathrm{H}), 5.80$ (ddt, $J=17.5,10.6,5.4 \mathrm{~Hz}, 1 \mathrm{H}), 5.34(\mathrm{~m}, 1 \mathrm{H}), 5.29(\mathrm{~d}, J=9.7 \mathrm{~Hz}, 1 \mathrm{H})$, 5.26-5.18 (m, 2H), $5.12(\mathrm{~m}, 1 \mathrm{H}), 4.71-4.57(\mathrm{~m}, 4 \mathrm{H}), 4.26-4.16(\mathrm{~m}, 2 \mathrm{H}), 4.09-3.99(\mathrm{~m}, 2 \mathrm{H}), 3.97-3.92$ (m, 2H), $3.88(\mathrm{dd}, J=16.9,6.8 \mathrm{~Hz}, 1 \mathrm{H}), 3.82-3.71(\mathrm{~m}, 2 \mathrm{H}), 3.42(\mathrm{dd}, J=16.8,5.6 \mathrm{~Hz}, 1 \mathrm{H}), 3.30$ (dd, $J=14.1,5.5 \mathrm{~Hz}, 1 \mathrm{H}), 3.02(\mathrm{~m}, 1 \mathrm{H}), 2.65(\mathrm{dd}, J=14.2,11.8 \mathrm{~Hz}, 1 \mathrm{H}), 0.77(\mathrm{~d}, J=6.4 \mathrm{~Hz}, 3 \mathrm{H}) .{ }^{13} \mathbf{C}$ NMR $\left(126 \mathrm{MHz}\right.$, Acetone- $\left.d_{6}\right) \delta 171.4,169.2,169.0,167.4,158.1,156.6,149.9,146.5,138.9,134.8,132.4$, $130.6,130.1,129.1,128.7,128.1,128.0,127.7,127.6,127.5,124.0,119.0,117.4,116.1,115.5,109.9$, $80.2,78.9,74.8,73.8,69.5,65.2,62.7,59.4,55.9,52.2,42.7,37.9,35.3,14.2$. HRMS (ESI) $m / z$ : $[\mathrm{M}+\mathrm{H}]^{+}$) calcd for $\mathrm{C}_{45} \mathrm{H}_{50} \mathrm{~N}_{5} \mathrm{O}_{14} \mathrm{~S} 916.3069$; found 916.3067 . 


\section{C-terminal macrocycle carboxylic acid (S5)}

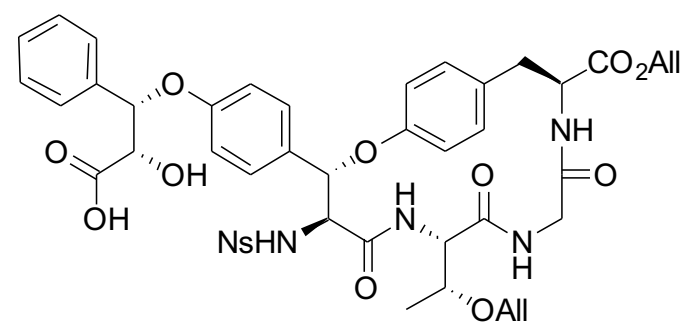

To a stirred solution of diol $24(50 \mathrm{mg}, 0.055 \mathrm{mmol})$ and TEMPO (9.4 mg, $0.06 \mathrm{mmol})$ in acetone (330 $\mu \mathrm{l})$ at $0{ }^{\circ} \mathrm{C}, \mathrm{KBr}(1.0 \mathrm{mg}, 10 \mathrm{~mol} \%, 0.005 \mathrm{mmol})$ and $5 \%$ aqueous $\mathrm{NaHCO}_{3}$ solution $(142 \mu \mathrm{l})$ were added. $9 \% \mathrm{NaOCl}(96 \mu \mathrm{l}, 0.011 \mathrm{mmol})$ was added and the mixture was stirred for $45 \mathrm{~h}$ at $0{ }^{\circ} \mathrm{C} .5 \% \mathrm{NaHCO}_{3}$ $(0.4 \mathrm{ml}, 0.144 \mathrm{mmol})$ was added to quench the reaction mixture and the solvent was evaporated under reduced pressure. The compound was purified using HPLC to give the carboxylic acid $\mathbf{S 5}$ (42 $\mathrm{mg}, 85 \%$ ) as a white solid. ${ }^{1} \mathbf{H}$ NMR $\left(500 \mathrm{MHz}\right.$, acetone- $\left.d_{6}\right) \delta 8.31(\mathrm{~d}, J=8.5 \mathrm{~Hz}, 2 \mathrm{H}), 7.96(\mathrm{~d}, J=8.5 \mathrm{~Hz}, 2 \mathrm{H}), 7.66$ $(\mathrm{d}, J=6.8 \mathrm{~Hz}, 1 \mathrm{H}), 7.50(\mathrm{~d}, J=7.6 \mathrm{~Hz}, 2 \mathrm{H}), 7.39-7.29(\mathrm{~m}, 5 \mathrm{H}), 7.26(\mathrm{~d}, J=7.4 \mathrm{~Hz}, 1 \mathrm{H}), 7.14(\mathrm{t}, J=6.3 \mathrm{~Hz}$, $1 \mathrm{H}), 6.97(\mathrm{t}, J=9.6 \mathrm{~Hz}, 3 \mathrm{H}), 6.86(\mathrm{~d}, J=8.4 \mathrm{~Hz}, 2 \mathrm{H}), 6.69(\mathrm{~d}, J=8.4 \mathrm{~Hz}, 2 \mathrm{H}), 6.50(\mathrm{~d}, J=7.0 \mathrm{~Hz}, 1 \mathrm{H}), 5.95$ (ddt, $J=16.3,10.7,5.4 \mathrm{~Hz}, 1 \mathrm{H}), 5.80$ (ddt, $J=21.1,10.4,5.1 \mathrm{~Hz}, 1 \mathrm{H}), 5.61$ (d, $J=4.8 \mathrm{~Hz}, 1 \mathrm{H}), 5.36$ (d, $J=17.3 \mathrm{~Hz}, 1 \mathrm{H}), 5.30(\mathrm{~d}, J=9.8 \mathrm{~Hz}, 1 \mathrm{H}), 5.25-5.17(\mathrm{~m}, 2 \mathrm{H}), 5.12(\mathrm{~d}, J=10.6 \mathrm{~Hz}, 1 \mathrm{H}), 4.73-4.56(\mathrm{~m}, 5 \mathrm{H})$, $4.18(\mathrm{~m}, 1 \mathrm{H}), 3.94(\mathrm{~d}, J=5.4 \mathrm{~Hz}, 2 \mathrm{H}), 3.87(\mathrm{dd}, J=16.7,6.8 \mathrm{~Hz}, 1 \mathrm{H}), 3.72(\mathrm{~s}, 1 \mathrm{H}), 3.43(\mathrm{~m}, 1 \mathrm{H}), 3.0(\mathrm{~m}$, 1H), 2.71-2.57 (m, 1H), $0.76(\mathrm{~d}, J=6.3 \mathrm{~Hz}, 3 \mathrm{H}) .{ }^{13} \mathbf{C}$ NMR (126 MHz, acetone- $\left.d_{6}\right) \delta 172.3,171.4,169.2$, $169.0,167.4,157.7,156.5,149.8,146.5,137.1,134.8,132.4,131.0,130.2,130.1,129.2,129.1,128.7$, $128.6,128.1,128.0,127.9,127.8,127.7,127.6,124.0,123.8,119.0,117.3,116.1,116.0,115.5,109.9$, 80.7, 78.9, 74.0, 73.8, 69.5, 65.2, 59.4, 55.9, 52.2, 42.6, 35.3, 14.2. HRMS (ESI) $m / z:[\mathrm{M}+\mathrm{H}]^{+}$) calcd for $\mathrm{C}_{45} \mathrm{H}_{48} \mathrm{~N}_{5} \mathrm{O}_{15} \mathrm{~S}$ 930.2862; found 930.2865. 


\section{C-terminal macrocycle amine acid (25)}

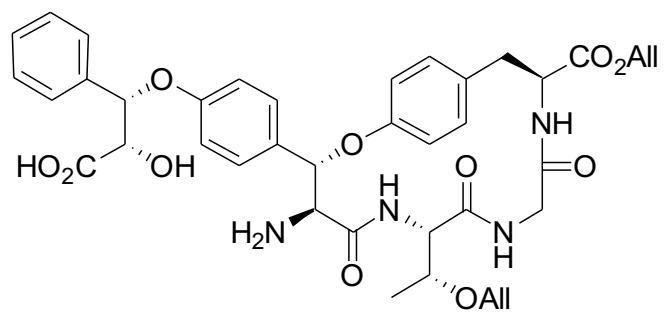

Compound S5 $(23 \mathrm{mg}, 0.025 \mathrm{mmol})$ was dissolved in $[\mathrm{Bmim}]-\left[\mathrm{BF}_{4}\right](430 \mu \mathrm{l})$ and $\mathrm{NEt}_{3}(51 \mu \mathrm{l}, 0.375$ mmol), then mercaptoacetic acid (16 $\mu \mathrm{l}, 0.225 \mathrm{mmol})$ was added. The mixture was stirred for $4 \mathrm{~h}$. The mixture was purified by preparative HPLC to afford the amine 25 (16 $\mathrm{mg}, 85 \%)$ as a white solid. ${ }^{1} \mathbf{H}$ NMR (600 MHz, CD 3 OD) $\delta 8.40(\mathrm{~d}, J=7.1 \mathrm{~Hz}, 1 \mathrm{H}), 7.47-7.38(\mathrm{~m}, 5 \mathrm{H}), 7.35-7.29(\mathrm{~m}, 2 \mathrm{H}), 7.28-7.21$ (m, 1H), $7.14(\mathrm{~d}, J=7.5 \mathrm{~Hz}, 1 \mathrm{H}), 7.01(\mathrm{~d}, J=7.2 \mathrm{~Hz}, 4 \mathrm{H}), 6.98(\mathrm{~d}, J=8.9 \mathrm{~Hz}, 1 \mathrm{H}), 6.79(\mathrm{~d}, J=8.7 \mathrm{~Hz}, 1 \mathrm{H})$, 6.75-6.70 (m, 1H), 6.02-5.84 (m, 2H), $5.52(\mathrm{~d}, J=5.3 \mathrm{~Hz}, 1 \mathrm{H}), 5.38-5.35(\mathrm{~m}, 3 \mathrm{H}), 5.27(\mathrm{~m}, 2 \mathrm{H}), 5.24$ $(\mathrm{d}, J=10.4 \mathrm{~Hz}, 1 \mathrm{H}), 5.15(\mathrm{~d}, J=10.4 \mathrm{~Hz}, 1 \mathrm{H}), 4.72-4.62(\mathrm{~m}, 3 \mathrm{H}), 4.53(\mathrm{~d}, J=5.3 \mathrm{~Hz}, 1 \mathrm{H}), 4.39$ (d, $J=9.9$ $\mathrm{Hz}, 1 \mathrm{H}), 4.27(\mathrm{~m}, 1 \mathrm{H}), 4.11-4.02(\mathrm{~m}, 2 \mathrm{H}), 3.84(\mathrm{~m}, 1 \mathrm{H}), 3.75(\mathrm{~m}, 1 \mathrm{H}), 3.3 .47(\mathrm{~m}, 1 \mathrm{H}), 3.34(\mathrm{dd}, J=14.2$, $5.5 \mathrm{~Hz}, 1 \mathrm{H}), 2.73(\mathrm{dd}, J=14.1,11.8 \mathrm{~Hz}, 2 \mathrm{H}), 1.00(\mathrm{~d}, J=6.3 \mathrm{~Hz}, 3 \mathrm{H}) .{ }^{13} \mathbf{C} \mathbf{N M R}\left(151 \mathrm{MHz}, \mathrm{CD}_{3} \mathrm{OD}\right) \delta$ $173.2,171.2,170.4,167.8,166.9,158.8,156.0,136.6,134.6,131.8,129.9,129.1,128.9,128.7,128.1$, $127.9,127.4,124.9,118.9,117.6,117.4,116.4,116.1,109.4,80.6,76.8,74.0,69.8,65.5,56.4,55.9$, 52.3, 42.5, 35.0, 13.9. HRMS (ESI) $m / z:[\mathrm{M}+\mathrm{H}]^{+}$) calcd for $\mathrm{C}_{39} \mathrm{H}_{45} \mathrm{~N}_{4} \mathrm{O}_{11}$ 745.3079; found 745.3079.

\section{Boc-Tyr(OAII)-OH (26)}

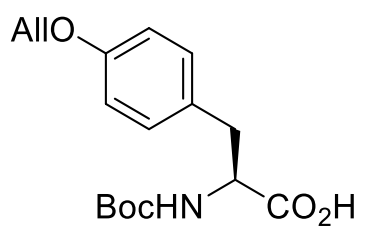

Boc-tyrosine $(2.95 \mathrm{~g}, 6.8 \mathrm{mmol})$ was dissolved in DMF $(50 \mathrm{~mL})$. The solution was cooled to $0{ }^{\circ} \mathrm{C}$ and $\mathrm{NaH}$ (675 mg from a 60\% NaH in mineral oil, $17.6 \mathrm{mmol}$ ) was added. The mixture was gradually warmed 
up to $5{ }^{\circ} \mathrm{C}$ and stirred for an additional $2 \mathrm{~h}$. Allyl bromide $(0.64 \mathrm{ml}, 7.4 \mathrm{mmol})$ was added and the mixture was warmed to room temperature and stirred for an additional $5 \mathrm{~h} .1 \mathrm{~N} \mathrm{HCl}(50 \mathrm{ml})$ was gradually added at $0{ }^{\circ} \mathrm{C}$. The aqueous layer was extracted with ethyl acetate $(3 \times 30 \mathrm{ml})$. The combined organic layer was dried over anhydrous $\mathrm{MgSO}_{4}$ and solvent was evaporated under reduced pressure. The compound was purified using column chromatography $(5-10 \% \mathrm{MeOH} / \mathrm{DCM})$ to yield the protected tyrosine $\mathbf{2 6}$ as a white solid (1.3 g, $85 \%) ;{ }^{1} \mathbf{H}$ NMR (400 MHz, $\left.\mathrm{CDCl}_{3}\right) \delta 6.97(\mathrm{~d}, J=5.3 \mathrm{~Hz}, 2 \mathrm{H}), 6.72(\mathrm{~d}, J=8.0 \mathrm{~Hz}, 2 \mathrm{H})$, 5.87 (ddt, $J=16.5,10.9,5.9 \mathrm{~Hz}, 1 \mathrm{H}), 5.31$ (d, $J=17.2 \mathrm{~Hz}, 1 \mathrm{H}), 5.25$ (d, $J=10.3 \mathrm{~Hz}, 1 \mathrm{H}), 5.11-4.85$ (m, 1H), $4.60(\mathrm{~d}, J=5.8 \mathrm{~Hz}, 2 \mathrm{H}), 4.58-4.52(\mathrm{~m}, 1 \mathrm{H}), 3.01(\mathrm{~m}, 2 \mathrm{H}), 1.42(\mathrm{~s}, 9 \mathrm{H}) .{ }^{13} \mathbf{C} \mathbf{N M R}\left(101 \mathrm{MHz}, \mathrm{CDCl}_{3}\right)$ $\delta 171.8,155.1,131.5,130.5,130.4,127.5,119.0,115.5,80.1,66.0,54.6,37.5,28.3$. HRMS (ESI) $m / z$ : $[\mathrm{M}+\mathrm{H}]^{+}$) calcd for $\mathrm{C}_{17} \mathrm{H}_{24} \mathrm{NO}_{5} 322.1649$; found 322.1650.

\section{Extended $C$-terminal macrocycle (27)}

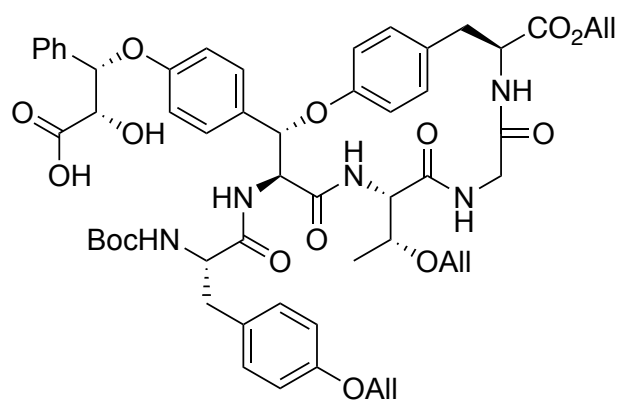

To a solution of Boc-Tyr(All)-OH $26(5.0 \mathrm{mg}, 0.015 \mathrm{mmol})$ in a mixture of DMF/DCM $(2: 1,150 \mu \mathrm{l})$, EDC.Cl (2.1 mg, $0.014 \mathrm{mmol}), \mathrm{HOBt}(2 \mathrm{mg}, 0.014 \mathrm{mmol})$, and $\mathrm{Et}_{3} \mathrm{~N}(3 \mu \mathrm{l}, 0.02 \mathrm{mmol})$ were added at 0 ${ }^{\circ} \mathrm{C}$. The mixture was stirred for $15 \mathrm{~min}$ at $0{ }^{\circ} \mathrm{C}$ and transferred to a solution of the compound $\mathbf{2 5}(10 \mathrm{mg}$, $0.0134 \mathrm{mmol})$ in DMF $(20 \mu \mathrm{l})$. The mixture was stirred for $2 \mathrm{~h}$ at $0{ }^{\circ} \mathrm{C}$ and the solvent was evaporated under reduced pressure. The residue was purified using preparative HPLC to give the extended macrocycle 27 as a white foam $(11 \mathrm{mg}, 80 \%) .{ }^{1} \mathbf{H}$ NMR $\left(500 \mathrm{MHz}, \mathrm{CD}_{3} \mathrm{OD}\right) \delta 8.34(\mathrm{~d}, J=7.5 \mathrm{~Hz}, 1 \mathrm{H})$, $7.88(\mathrm{~d}, J=8.4 \mathrm{~Hz}, 1 \mathrm{H}), 7.75(\mathrm{~d}, J=8.4,1 \mathrm{H}), 7.55(\mathrm{~m}, 1 \mathrm{H}), 7.49(\mathrm{~m}, 1 \mathrm{H}), 7.42(\mathrm{~m}, 1 \mathrm{H}), 7.40-7.32(\mathrm{~m}$, 
3H), 7.28-7.23 (m, 1H), 7.22-7.14 (m, 2H), $7.13(\mathrm{~m}, 1 \mathrm{H}), 6.99$ (d, J=8.7 Hz, 4H), 6.94-6.87 (m, 2H), $6.84(\mathrm{dd}, J=14.3,8.3 \mathrm{~Hz}, 5 \mathrm{H}), 5.49$ (d, $J=4.8 \mathrm{~Hz}, 1 \mathrm{H}), 5.44-5.34(\mathrm{~m}, 3 \mathrm{H}), 5.29-5.20$ (m, 3H), 5.14 (m, 1H), $5.01(\mathrm{~d}, J=9.5 \mathrm{~Hz}, 1 \mathrm{H}), 4.75-4.63(\mathrm{~m}, 3 \mathrm{H}), 4.58-4.49(\mathrm{~m}, 4 \mathrm{H}), 4.28(\mathrm{~m}, 1 \mathrm{H}), 4.05(\mathrm{~m}, 1 \mathrm{H}), 3.97$ (m, 1H), 3.91 (d, $J=16.7 \mathrm{~Hz}, 1 \mathrm{H}), 3.80(\mathrm{~m}, 1 \mathrm{H}), 3.48$ (d, $J=16.6 \mathrm{~Hz}, 1 \mathrm{H}), 3.26(\mathrm{~m}, 1 \mathrm{H}), 3.08(\mathrm{~m}, 1 \mathrm{H})$, 2.91-2.70 (m, 2H), $2.47(\mathrm{~m}, 1 \mathrm{H}), 2.12(\mathrm{~m}, 1 \mathrm{H}), 1.38$ (d, $J=14.4 \mathrm{~Hz}, 9 \mathrm{H}), 0.99$ (d, $J=6.6 \mathrm{~Hz}, 3 \mathrm{H}) .{ }^{13} \mathrm{C}$ NMR (126 MHz, CD $\left.\mathrm{CD}_{3} \mathrm{OD}\right) \delta 173.3,171.3,170.4,136.6,134.7,133.7,133.6,131.9,129.9,129.7,128.9$, $127.9,127.8,127.3,124.9,117.4,115.9,115.9,115.3,114.7,114.4,114.3,110.0,80.7,74.1,69.9,68.4$, 65.6, 56.5, 52.4, 42.5, 29.25, 27.3, 22.8, 14.2. HRMS (ESI) $m / z:[\mathrm{M}+\mathrm{H}]^{+}$) calcd for $\mathrm{C}_{56} \mathrm{H}_{66} \mathrm{~N}_{5} \mathrm{O}_{15}$ 1048.4550; found 1048.4548 .

\section{Bicyclic peptide (28)}

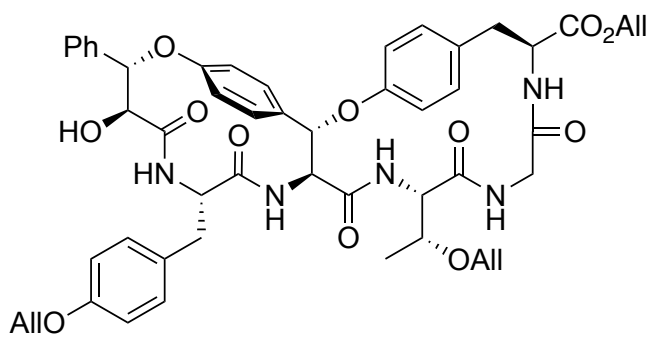

Macrocycle $27(5.0 \mathrm{mg}, 5 \mu \mathrm{mol})$ was dissolved in a solution of 20\% TFA in DCM (1 ml) and stirred for $1 \mathrm{~h}$ at $0{ }^{\circ} \mathrm{C}$. The solvent was evaporated and dried under vacuum. The residue was dissolved in a mixture of DMF/DCM $(0.5 / 100,100 \mathrm{ml})$ and HATU $(2.0 \mathrm{mg}, 5.2 \mu \mathrm{mol})$, HOAt $(10 \mu \mathrm{l}$ from a $1 \mathrm{M}$ solution in DMF, $10 \mu \mathrm{mol})$, and $\mathrm{Et}_{3} \mathrm{~N}(10 \mu \mathrm{l}, 74 \mu \mathrm{mol})$ were added. The mixture was stirred overnight and the solvent was evaporated under reduced pressure. The residue was purified by HPLC to give bicyclic compound 28 as a white foam (3.0 mg, 64\%). Retention time: 18.59 minutes. ${ }^{1} \mathbf{H}$ NMR $\left(600 \mathrm{MHz}\right.$, DMSO- $\left.d_{6}\right) \delta$ $8.45(\mathrm{~d}, J=8.1 \mathrm{~Hz}, 1 \mathrm{H}), 8.09(\mathrm{~d}, J=10.4 \mathrm{~Hz}, 1 \mathrm{H}), 7.77(\mathrm{~d}, J=9.6 \mathrm{~Hz}, 1 \mathrm{H}), 7.56(\mathrm{~d}, J=7.4 \mathrm{~Hz}, 2 \mathrm{H}), 7.52(\mathrm{~d}$, $J=7.6 \mathrm{~Hz}, 1 \mathrm{H}), 7.48-7.42(\mathrm{~m}, 3 \mathrm{H}), 7.39(\mathrm{~d}, J=7.3 \mathrm{~Hz}, 1 \mathrm{H}), 7.30(\mathrm{~d}, J=8.5 \mathrm{~Hz}, 2 \mathrm{H}), 7.16$ (s, 1H), $7.12(\mathrm{~d}$, $J=8.0 \mathrm{~Hz}, 2 \mathrm{H}), 7.09(\mathrm{~d}, J=8.1 \mathrm{~Hz}, 2 \mathrm{H}), 6.83(\mathrm{dd}, J=13.3,9.6 \mathrm{~Hz}, 2 \mathrm{H}), 6.76(\mathrm{~d}, J=8.1 \mathrm{~Hz}, 2 \mathrm{H}), 6.12-5.98$ 
(m, 2H), $5.96(\mathrm{~d}, J=3.7 \mathrm{~Hz}, 1 \mathrm{H}), 5.93(\mathrm{~m}, 1 \mathrm{H}), 5.57(\mathrm{~d}, J=8.8 \mathrm{~Hz}, 1 \mathrm{H}), 5.47-5.39(\mathrm{~m}, 3 \mathrm{H}), 5.36-5.28(\mathrm{~m}$, $5 \mathrm{H}), 5.19(\mathrm{~m}, 1 \mathrm{H}), 4.76-4.70(\mathrm{~m}, 2 \mathrm{H}), 4.65(\mathrm{~d}, J=9.6 \mathrm{~Hz}, 1 \mathrm{H}), 4.61-4.54(\mathrm{~m}, 2 \mathrm{H}), 4.52(\mathrm{~d}, J=5.4 \mathrm{~Hz}$, 2H), 4.29 (dd, $J=8.2,3.1 \mathrm{~Hz}, 1 \mathrm{H}), 4.11-3.99(\mathrm{~m}, 3 \mathrm{H}), 3.85(\mathrm{dd}, J=6.4,3.1 \mathrm{~Hz}, 1 \mathrm{H}), 3.76(\mathrm{~m}, 1 \mathrm{H}), 2.73$ (d, $J=12.3 \mathrm{~Hz}, 1 \mathrm{H}), 2.67(\mathrm{~m}, 1 \mathrm{H}), 2.31(\mathrm{~m}, 1 \mathrm{H}), 1.03(\mathrm{~d}, J=6.3 \mathrm{~Hz}, 3 \mathrm{H})$. HRMS (ESI) $\left.m / z:[\mathrm{M}+\mathrm{H}]^{+}\right)$ calcd for $\mathrm{C}_{51} \mathrm{H}_{56} \mathrm{~N}_{5} \mathrm{O}_{12} 930.3920$; found 930.3921 .

\section{Protected asperipin-2a (29)}

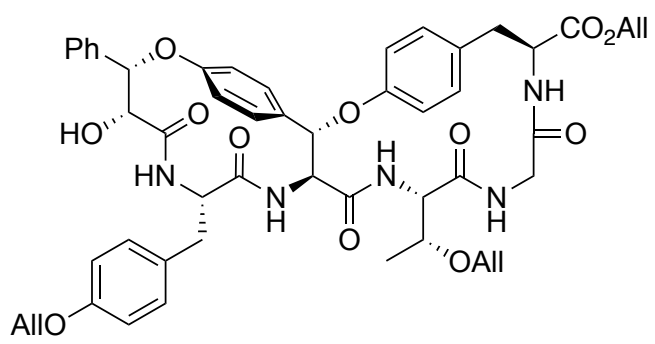

Bicyclic compound 28 ( $3.0 \mathrm{mg}, 3.2 \mu \mathrm{mol})$ was dissolved in THF (100 $\mu \mathrm{l})$ and pyridine (10\% pyridine in THF solution, $10 \mu \mathrm{l}, 10 \mu \mathrm{mol})$ was added at $-20{ }^{\circ} \mathrm{C}$. Trifluoromethanesulfonic anhydride $(10 \%$ trifluoromethanesulfonic anhydride in dry THF solution, $20 \mu \mathrm{l}, 10 \mu \mathrm{mol}$ ) was added and the mixture was stirred at $-10{ }^{\circ} \mathrm{C}$ for $2 \mathrm{~h}$. The solvent was evaporated under reduced pressure and dried under vacuum for $10 \mathrm{~h}$. The residue was subsequently dissolved in DMF $(100 \mu \mathrm{l})$ and tetrabutylammonium nitrite $\left(\mathrm{TBANO}_{2}\right)(5.0 \mathrm{mg}, 17 \mu \mathrm{mol})$ was added at room temperature and the mixture was stirred overnight. The solvent was evaporated under a stream of nitrogen and the residue was purified using HPLC to give the bicyclic compound $\mathbf{2 9}$ as a white foam (2.1 mg, 66\%). Retention time: 19.38 minutes. ${ }^{1} \mathbf{H}$ NMR (700 MHz, DMSO- $\left.d_{6}\right) \delta 8.16(\mathrm{~d}, J=7.9 \mathrm{~Hz}, 1 \mathrm{H}), 7.94-7.81(\mathrm{~m}, 2 \mathrm{H}), 7.55(\mathrm{~m}, 1 \mathrm{H}), 7.51(\mathrm{~d}, J=7.1 \mathrm{~Hz}, 2 \mathrm{H})$, 7.38 (d, $J=7.3 \mathrm{~Hz}, 2 \mathrm{H}), 7.24$ (d, $J=8.7 \mathrm{~Hz}, 1 \mathrm{H}), 7.13$ (d, J=7.3 Hz, 1H), 7.08 (d, $J=7.7 \mathrm{~Hz}, 1 \mathrm{H}), 7.03$ (d, $J=8.2 \mathrm{~Hz}, 2 \mathrm{H}), 6.96(\mathrm{~d}, J=8.7 \mathrm{~Hz}, 2 \mathrm{H}), 6.88(\mathrm{~m}, 1 \mathrm{H}), 6.81(\mathrm{~d}, J=8.5 \mathrm{~Hz}, 2 \mathrm{H}), 6.68(\mathrm{~d}, J=8.8 \mathrm{~Hz}, 2 \mathrm{H})$, 6.10-5.82 (m, 3H), $5.76(\mathrm{~s}, 1 \mathrm{H}), 5.53(\mathrm{~d}, J=8.7 \mathrm{~Hz}, 1 \mathrm{H}), 5.41-5.33(\mathrm{~m}, 3 \mathrm{H}), 5.31(\mathrm{~d}, J=8.8 \mathrm{~Hz}, 1 \mathrm{H})$, 5.29-5.19 (m, 4H), $5.13(\mathrm{~d}, J=11.2 \mathrm{~Hz}, 1 \mathrm{H}), 4.50-4.37(\mathrm{~m}, 1 \mathrm{H}), 4.28-4.12(\mathrm{~m}, 1 \mathrm{H}), 4.05(\mathrm{~m}, 1 \mathrm{H}), 4.02-$ 
$3.94(\mathrm{~m}, 6 \mathrm{H}), 3.80-3.61(\mathrm{~m}, 2 \mathrm{H}), 3.55(\mathrm{~m}, 1 \mathrm{H}), 3.46(\mathrm{~m}, 1 \mathrm{H}), 3.21(\mathrm{~m}, 1 \mathrm{H}), 3.10(\mathrm{~m}, 1 \mathrm{H}), 2.70(\mathrm{~m}, 1 \mathrm{H})$, $2.58(\mathrm{~m}, 1 \mathrm{H}), 2.38(\mathrm{~m}, 1 \mathrm{H}), 0.89(\mathrm{~d}, J=6.6 \mathrm{~Hz}, 3 \mathrm{H})$. HRMS (ESI) $m / z$ : $\left.[\mathrm{M}+\mathrm{H}]^{+}\right)$calcd for $\mathrm{C}_{51} \mathrm{H}_{56} \mathrm{~N}_{5} \mathrm{O}_{12}$ 930.3920; found 930.3921.

\section{epi-Asperipin-2a (1)}

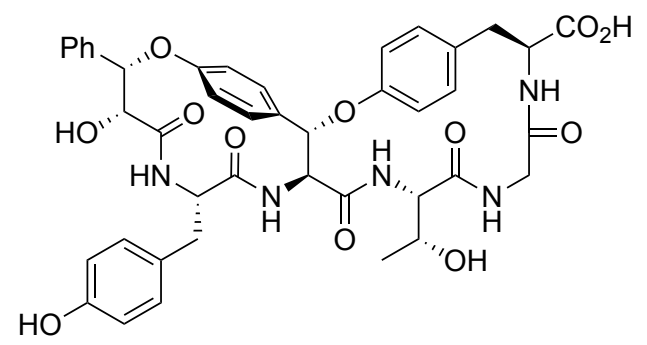

To a solution of protected asperipin-2a $29(2.0 \mathrm{mg}, 2.15 \mu \mathrm{mol})$ in THF (100 $\mu \mathrm{l}), \mathrm{Pd}\left(\mathrm{PPh}_{3}\right)_{4}(1.2 \mathrm{mg}, 1.07$ $\mu \mathrm{mol})$ and phenylsilane (10\% solution of phenylsilane in THF, $6 \mu \mathrm{l}, 4.3 \mu \mathrm{mol})$ were added under argon atmosphere. The mixture was stirred for $5 \mathrm{~h}$ and the solvent was evaporated. The crude material was purified by preparative HPLC to give epi-asperipin 1 as a white foam $(1.0 \mathrm{mg}, 48 \%) .{ }^{1} \mathbf{H}$ NMR $(700$ MHz, DMSO-d6) $\delta 9.06(\mathrm{~s}, 1 \mathrm{H}), 7.92(\mathrm{~m}, 1 \mathrm{H}), 7.82(\mathrm{~m}, 1 \mathrm{H}), 7.62(\mathrm{~m}, 1 \mathrm{H}), 7.50(\mathrm{~d}, J=7.8 \mathrm{~Hz}, 2 \mathrm{H}), 7.42$ (m, 1H), $7.38(\mathrm{~m}, 3 \mathrm{H}), 7.32(\mathrm{~d}, J=7.3 \mathrm{~Hz}, 1 \mathrm{H}), 7.07$ (d, $J=8.8 \mathrm{~Hz}, 1 \mathrm{H}), 7.02(\mathrm{~d}, J=8.7 \mathrm{~Hz}, 1 \mathrm{H}), 6.98-6.93$ $(\mathrm{m}, 3 \mathrm{H}), 6.87(\mathrm{~m}, 1 \mathrm{H}), 6.83(\mathrm{~d}, J=8.8 \mathrm{~Hz}, 2 \mathrm{H}), 6.77(\mathrm{~d}, J=8.3 \mathrm{~Hz}, 2 \mathrm{H}), 6.66(\mathrm{~d}, J=8.7 \mathrm{~Hz}, 1 \mathrm{H}), 6.50$ (dd, $J=8.7,2.1 \mathrm{~Hz}, 2 \mathrm{H}), 5.51(\mathrm{~d}, J=9.1 \mathrm{~Hz}, 1 \mathrm{H}), 5.24(\mathrm{~d}, J=9.6 \mathrm{~Hz}, 1 \mathrm{H}), 4.92(\mathrm{t}, J=9.3 \mathrm{~Hz}, 1 \mathrm{H}), 4.65(\mathrm{~m}, 1 \mathrm{H})$, $4.41(\mathrm{~m}, 1 \mathrm{H}), 4.15(\mathrm{~m}, 2 \mathrm{H}), 4.05(\mathrm{~m}, 1 \mathrm{H}), 3.98(\mathrm{~m}, 1 \mathrm{H}), 2.92(\mathrm{~m}, 1 \mathrm{H}), 2.57(\mathrm{~m}, 1 \mathrm{H}), 2.37(\mathrm{~m}, 1 \mathrm{H}), 0.89$ (d, $J=6.5 \mathrm{~Hz}, 3 \mathrm{H})$. HRMS (ESI) $m / z$ : $[\mathrm{M}+\mathrm{H}]^{+}$) calcd for $\mathrm{C}_{42} \mathrm{H}_{44} \mathrm{~N}_{5} \mathrm{O}_{12}$ 810.2981; found 810.2975. 
Figures S1-2: ${ }^{1} \mathrm{H}$ and ${ }^{13} \mathrm{C}$ NMR spectra of compound $3\left(500 / 126 \mathrm{MHz}, \mathrm{CDCl}_{3}\right)$

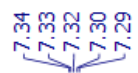<smiles>CC1(C)OC[C@H]([C@@H](O)c2ccccc2)O1</smiles>
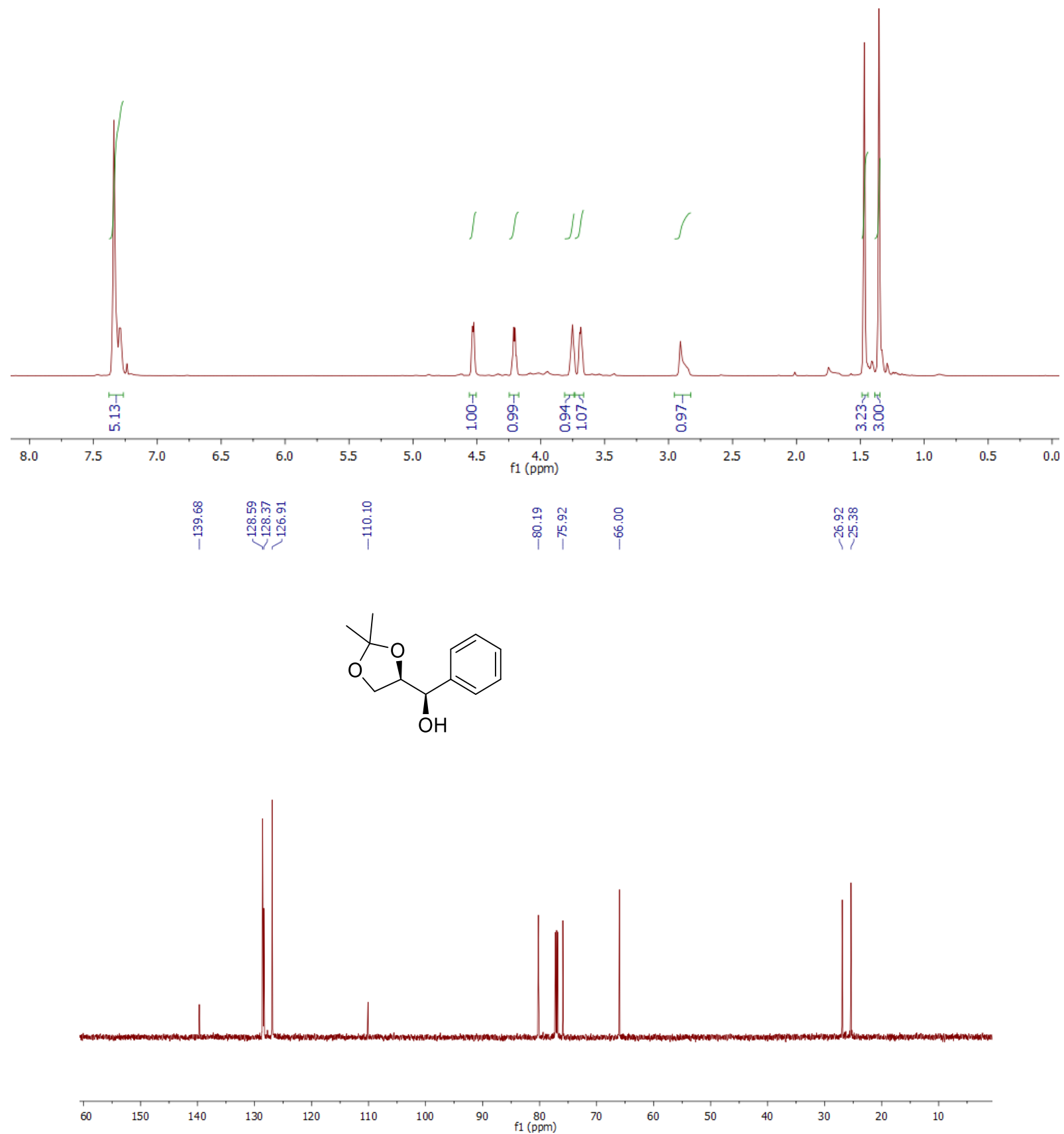
Figures S3-4: ${ }^{1} \mathrm{H}$ and ${ }^{13} \mathrm{C}$ NMR spectra of $\mathbf{S 1}\left(600,150 \mathrm{MHz}\right.$, acetone- $\left.d_{6}\right)$

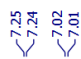

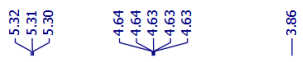
$\stackrel{\infty}{\infty}$ $\mathrm{BocO}$<smiles>CC(=O)OC(=O)[C@@H]1NC(=O)O[C@H]1c1ccc(I)cc1</smiles>

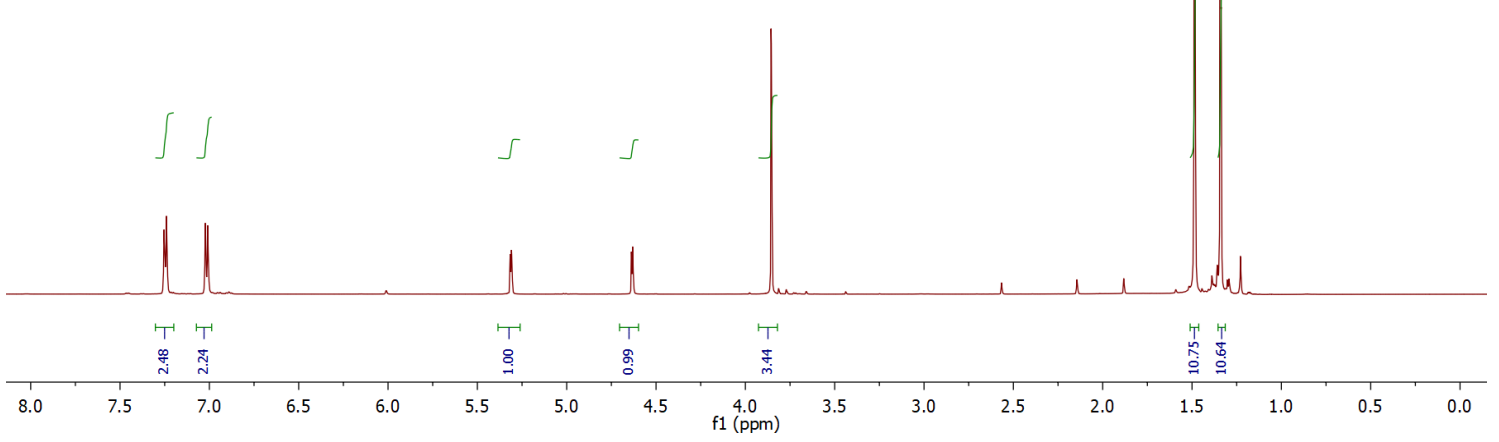

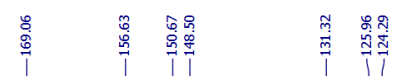

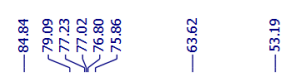

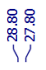

$\mathrm{BocO}$<smiles>COC(=O)[C@@H]1NC(=O)O[C@H]1c1ccc(C)cc1</smiles>

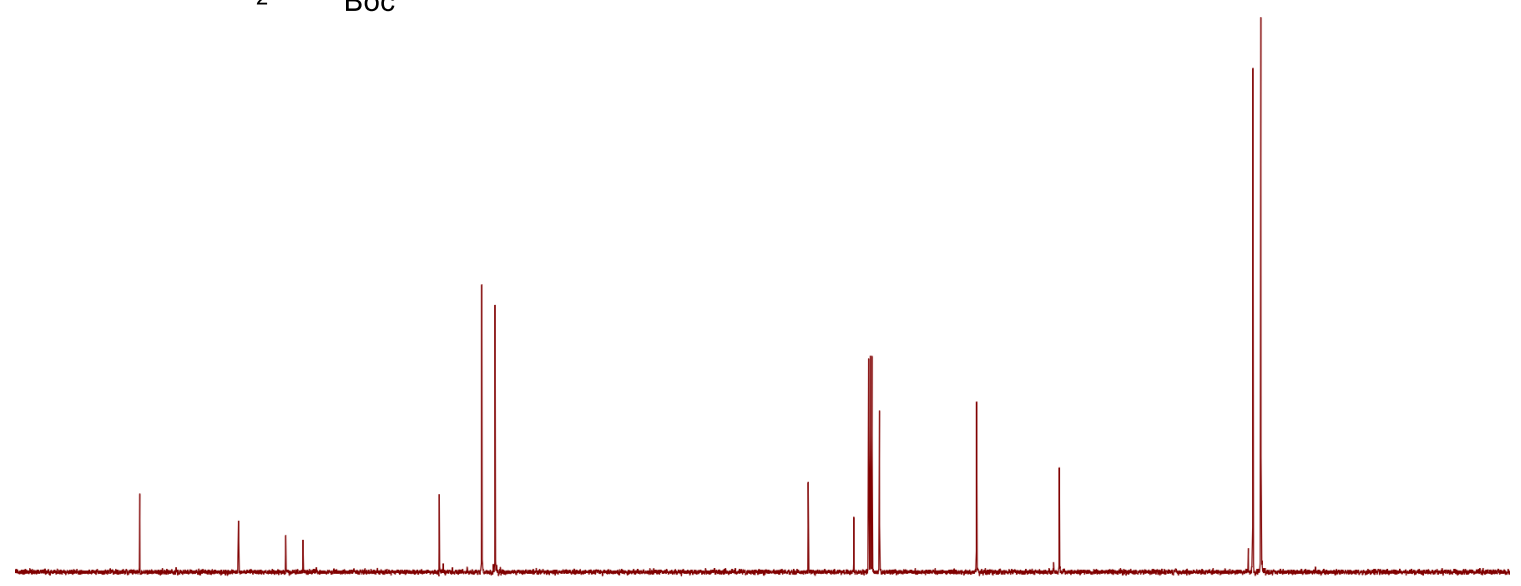

180 
Figures S5-6: ${ }^{1} \mathrm{H}$ and ${ }^{13} \mathrm{C}$ NMR spectra of compound $5\left(600 / 151 \mathrm{MHz}\right.$, acetone- $\left.d_{6}\right)$

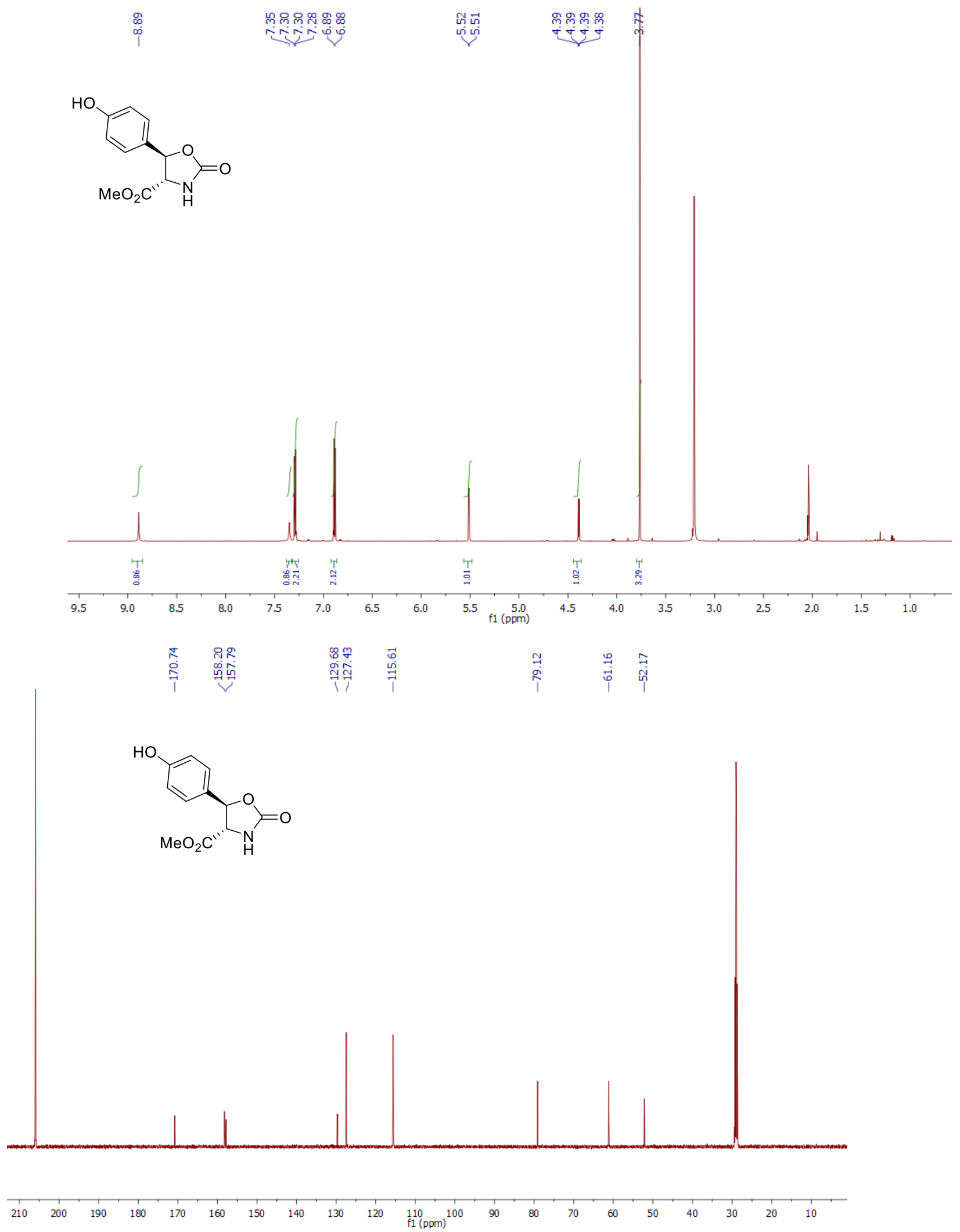


Figures S7-8: ${ }^{1} \mathrm{H}$ and ${ }^{13} \mathrm{C}$ NMR spectra of compound $6\left(500 / 126 \mathrm{MHz}, \mathrm{CDCl}_{3}\right)$

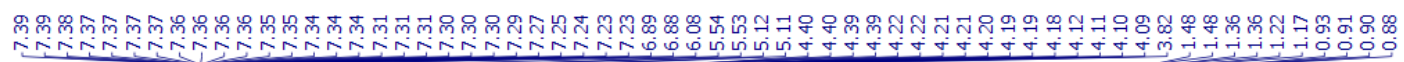<smiles>CO[C@H]1NC(=O)O[C@H]1c1ccc(O[C@H](c2ccccc2)[C@H]2COC(C)(C)O2)cc1</smiles>

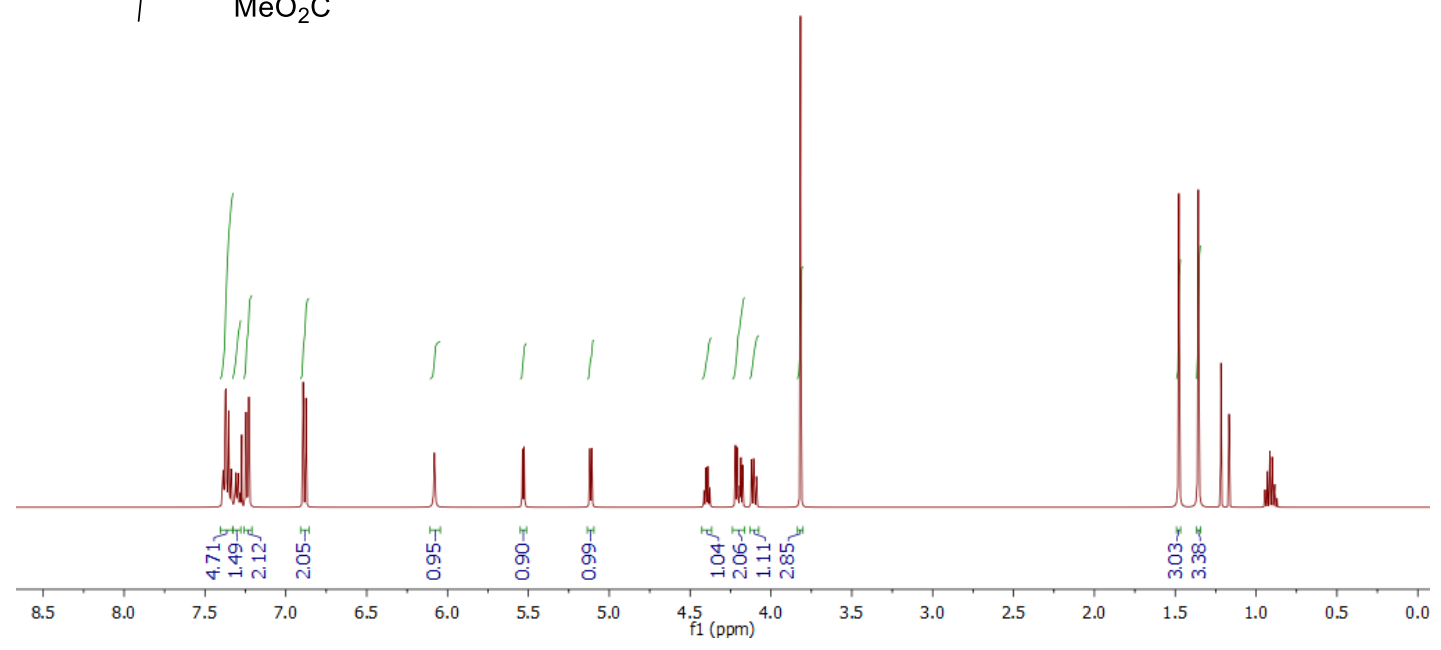

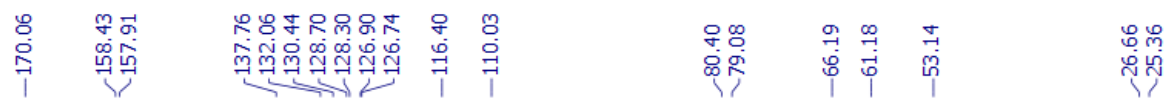<smiles>CO[C@H]1NC(=O)O[C@H]1c1ccc(O[C@H](c2ccccc2)[C@H]2COC(C)(C)O2)cc1</smiles>

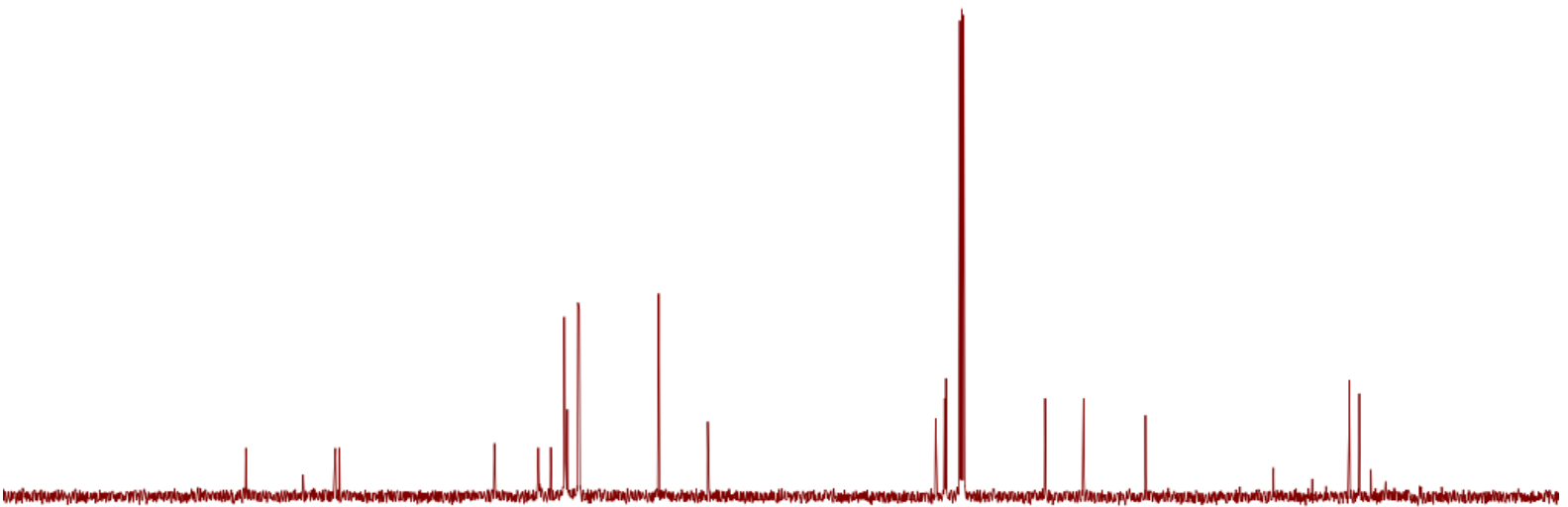

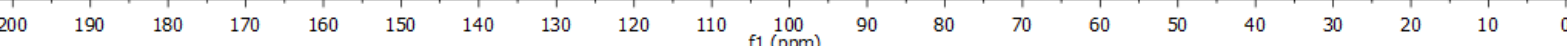


Figure S9: Mass spectrum of 6.

sh-239 \#86 RT: $0.81 \quad$ AV: 1 NL: 9.76E6

T: FTMS + p ESI Full lock ms [100.0000-1000.0000]
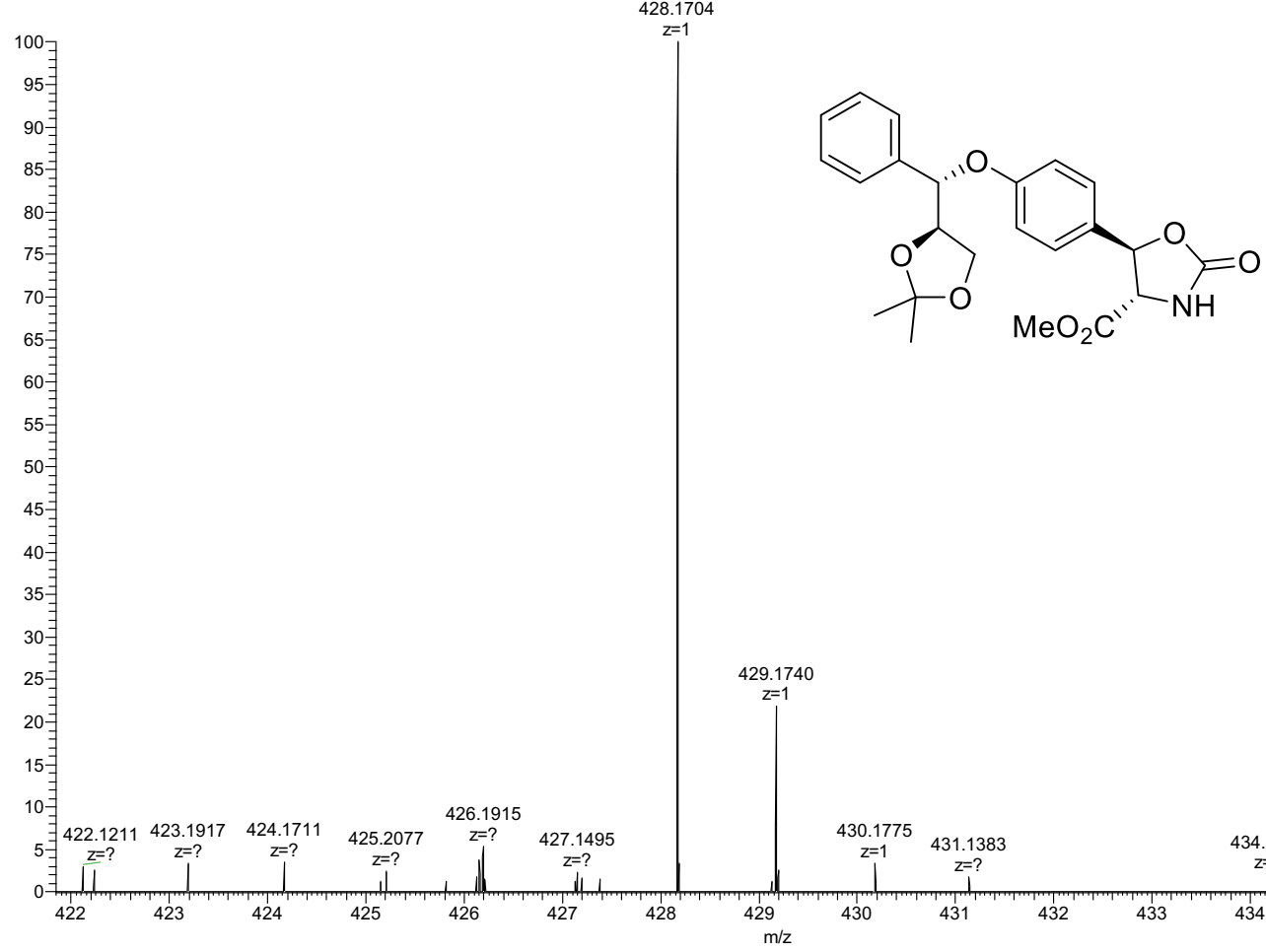

1740

$\underset{\substack{430.1775 \\ z=1}}{431.1383} \begin{gathered}434.1809 \\ z=? \\ z=?\end{gathered}$

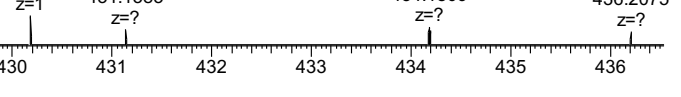


Figures S10-11: ${ }^{1} \mathrm{H}$ and ${ }^{13} \mathrm{C}$ NMR spectra of compound $7\left(500 / 126 \mathrm{MHz}, \mathrm{CDCl}_{3}\right)$

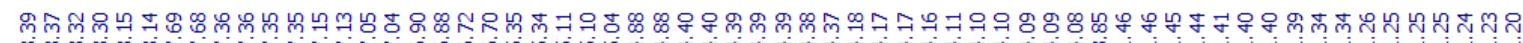

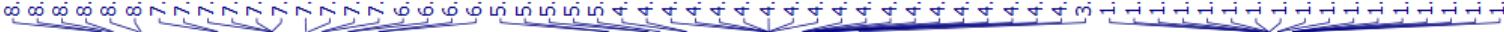<smiles>CO[C@H]1[C@H](c2ccc(O[C@H](c3ccccc3)[C@H]3COC(C)(C)O3)cc2)OC(=O)N1[N+](=O)[O-]</smiles>

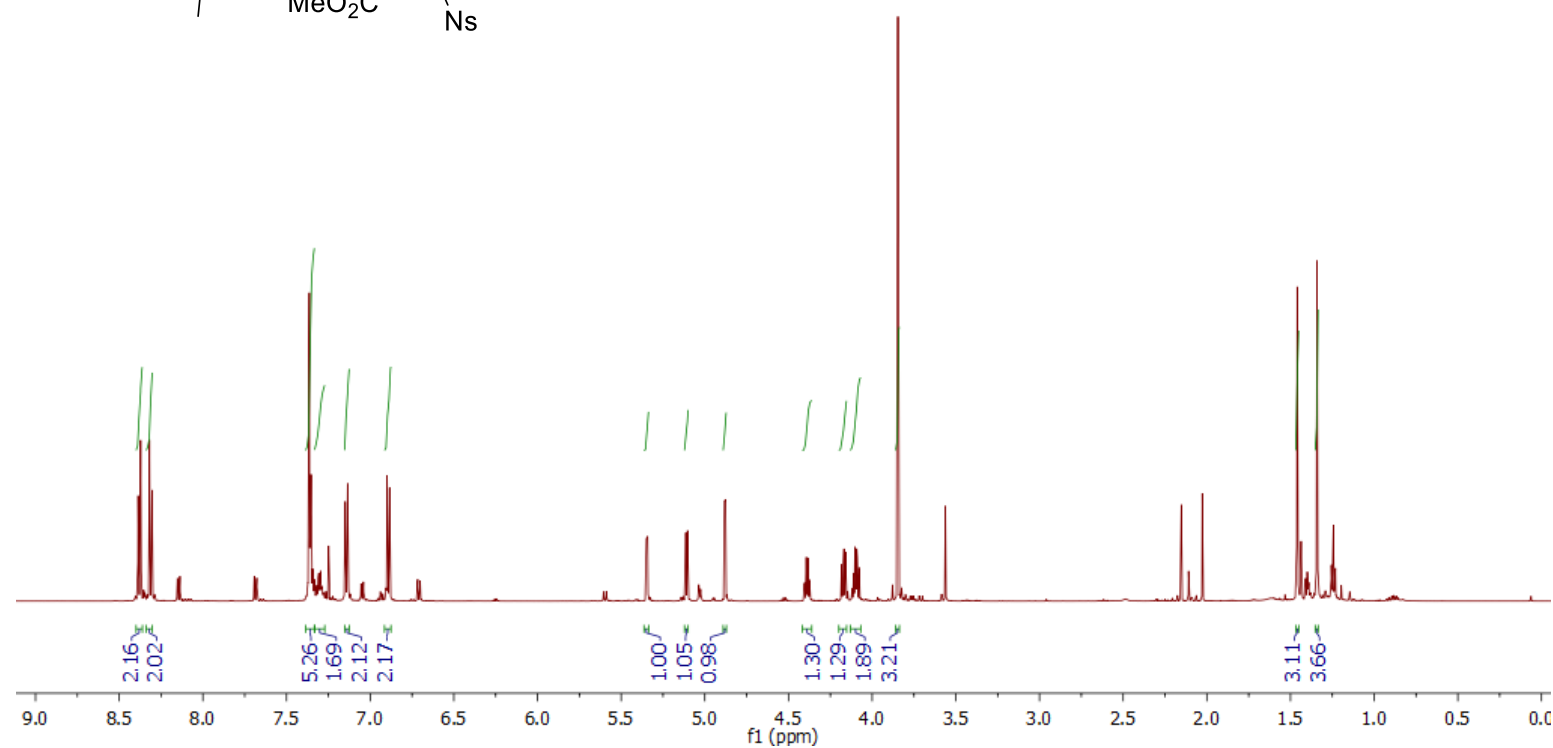

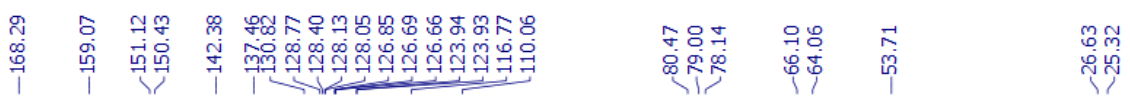<smiles>CO[C@H]1[C@H](c2ccc(O[C@H](c3ccccc3)[C@H]3COC(C)(C)O3)cc2)OC(=O)N1[N+](=O)[O-]</smiles>
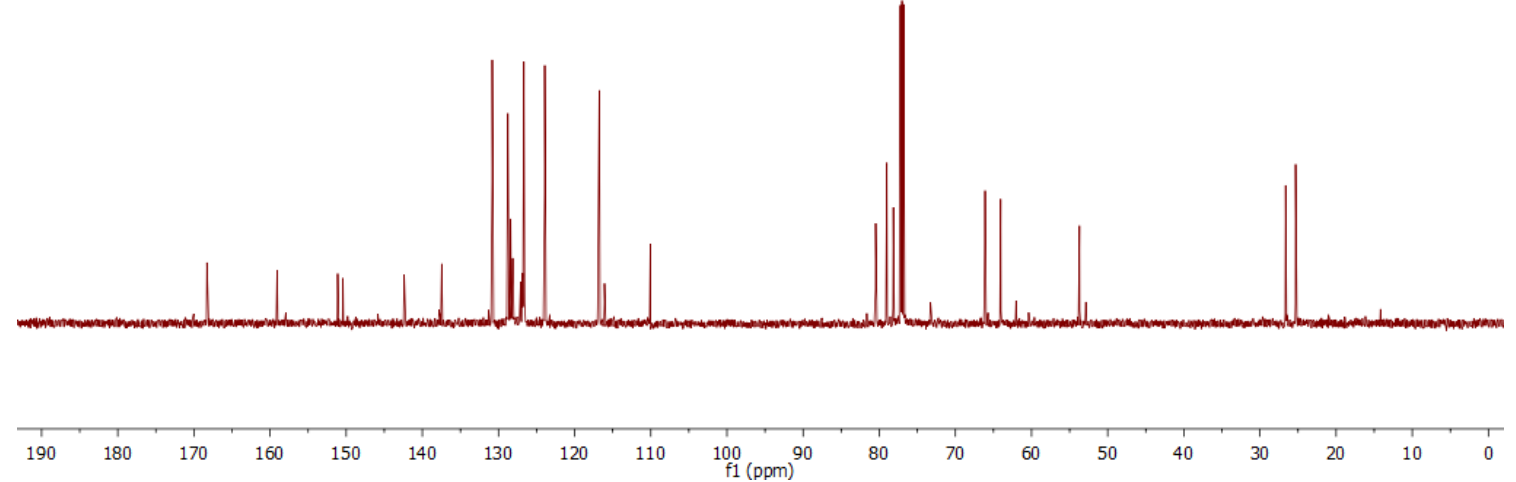
Figures S12-13: ${ }^{1} \mathrm{H}$ and ${ }^{13} \mathrm{C}$ NMR spectra of compound $8\left(500 / 126 \mathrm{MHz}, \mathrm{CDCl}_{3}\right)$
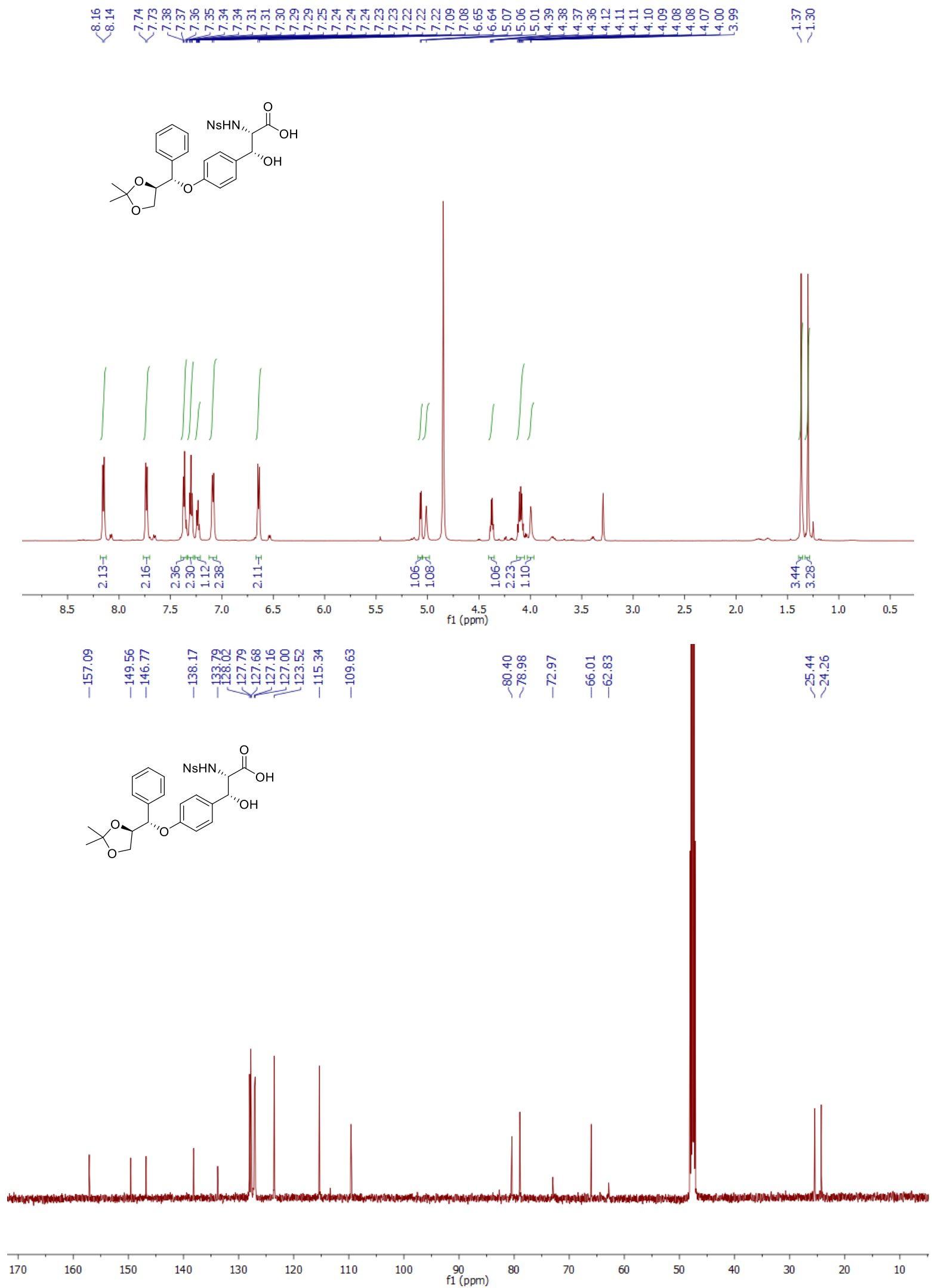
Figure S14: Mass spectrum of 8 .

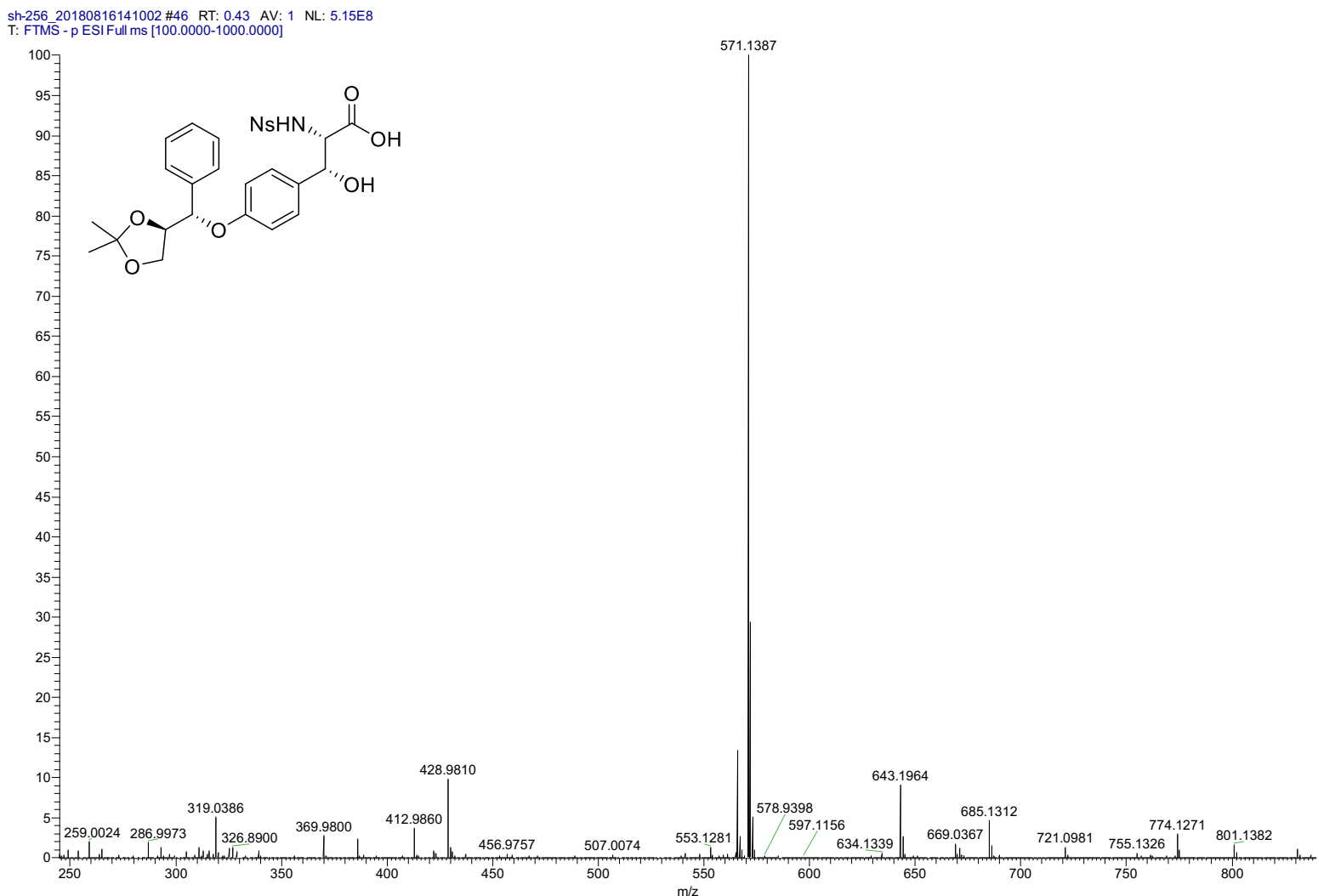


Figures S15-16: ${ }^{1} \mathrm{H}$ and ${ }^{13} \mathrm{C}$ NMR spectra of compound $10\left(500 / 126 \mathrm{MHz}, \mathrm{CDCl}_{3}\right)$

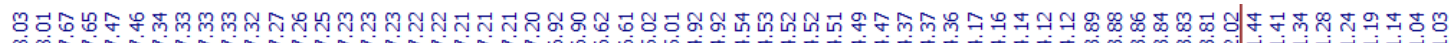

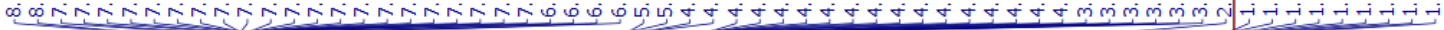<smiles>CCCCOC(=O)CNC(=O)[C@H](NC(=O)[C@H](N=N)[C@H](O)c1ccc(O[C@H](c2ccccc2)[C@H]2COC(C)(C)O2)cc1)C(C)C</smiles>
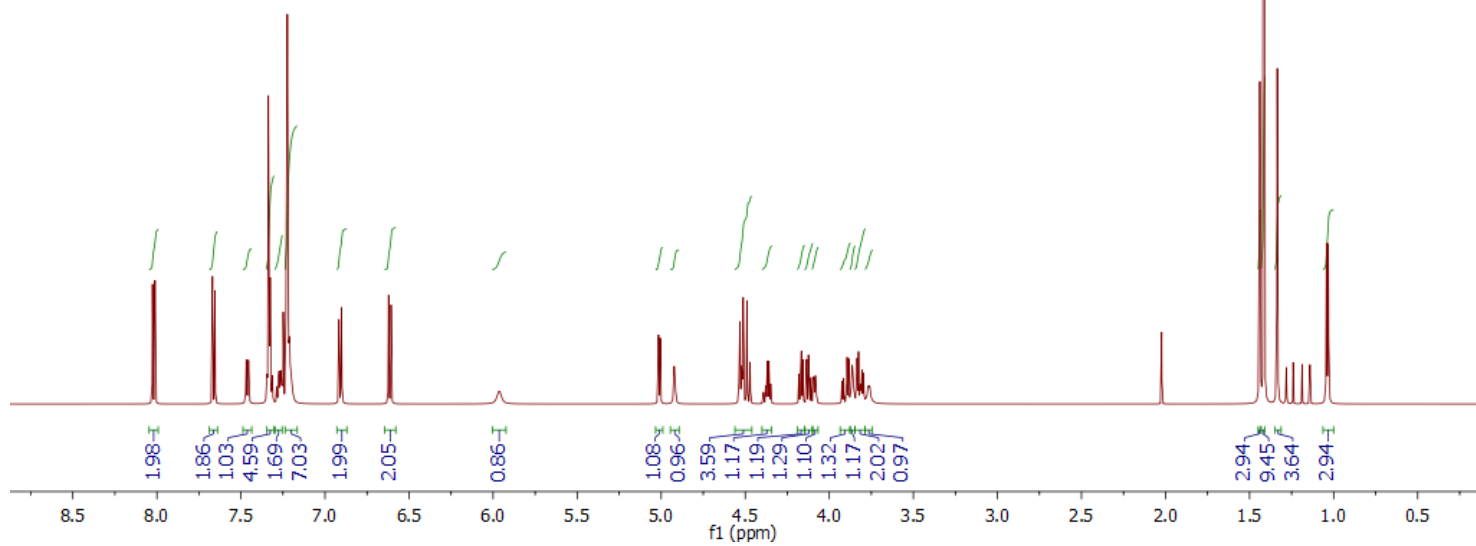

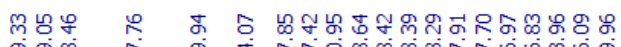

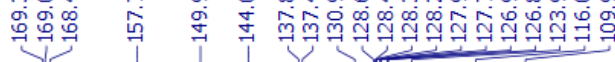
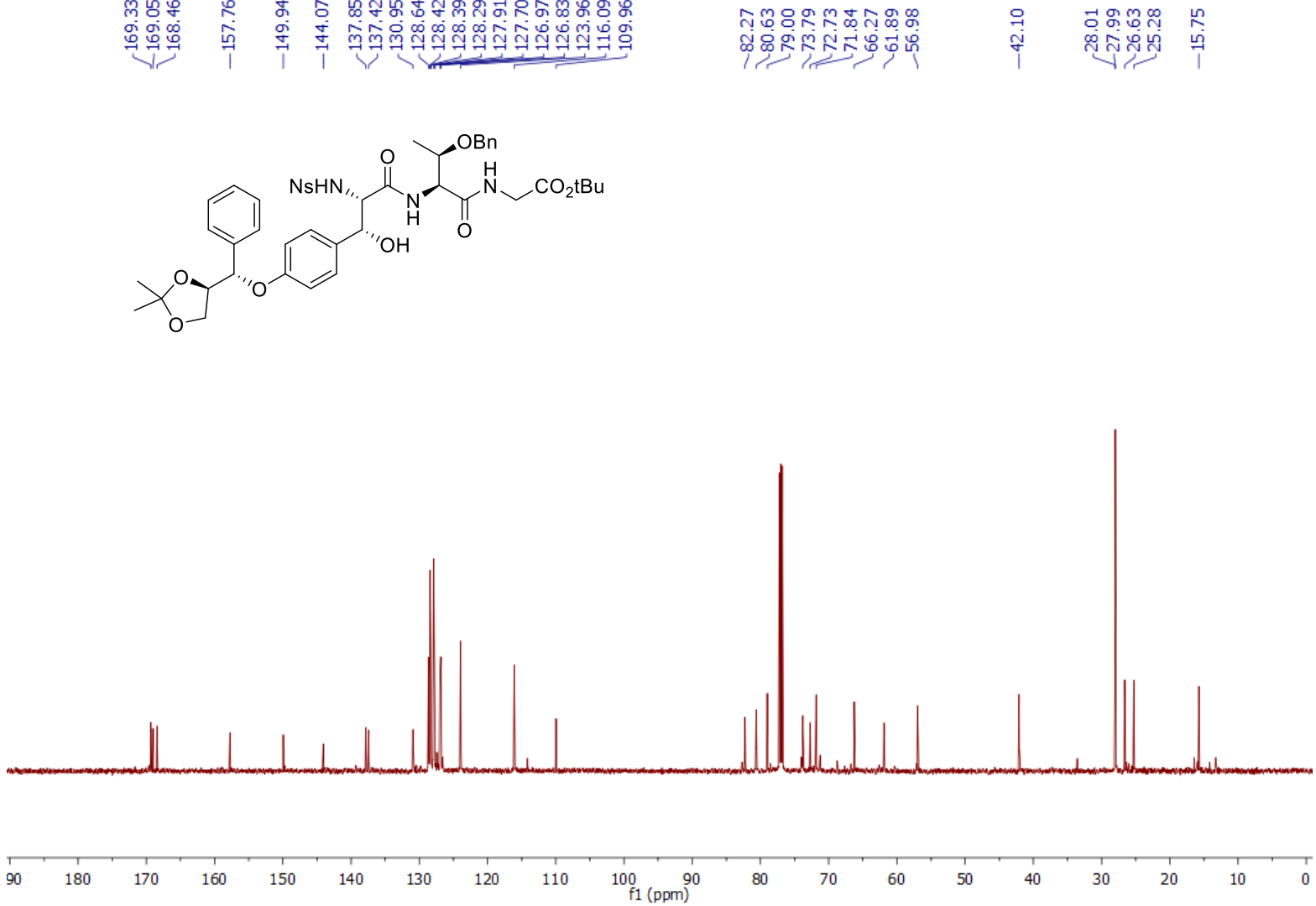
Figure S17: Mass spectrum of $\mathbf{1 0}$.

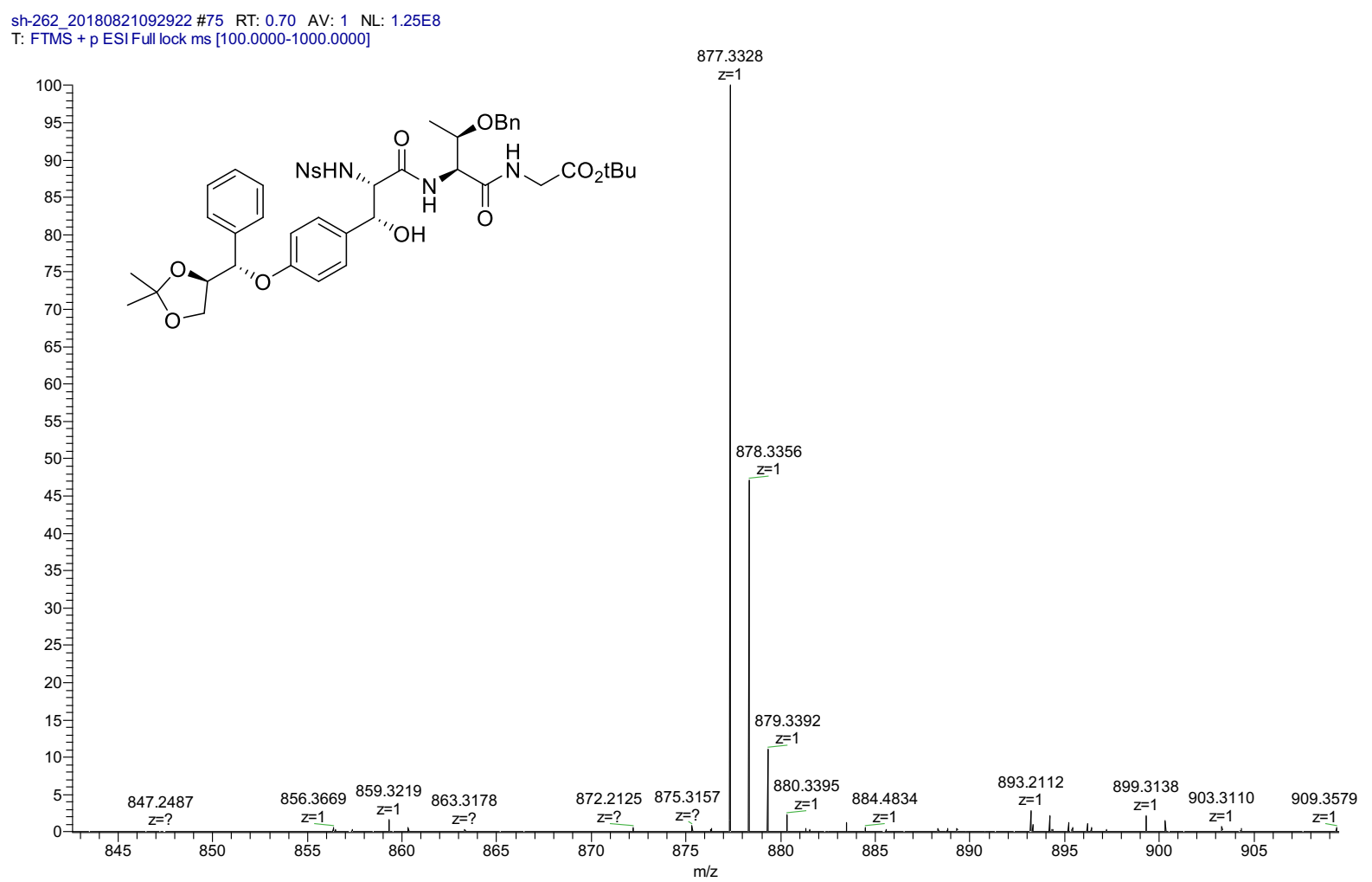


Figures S18-19: ${ }^{1} \mathrm{H}$ and ${ }^{13} \mathrm{C}$ NMR spectra of compound $11\left(500 / 126 \mathrm{MHz}, \mathrm{CDCl}_{3}\right)$

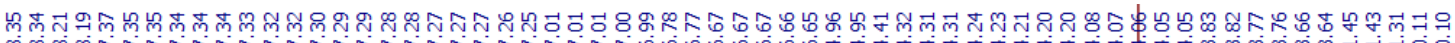

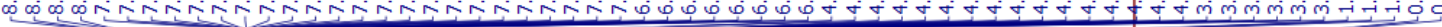

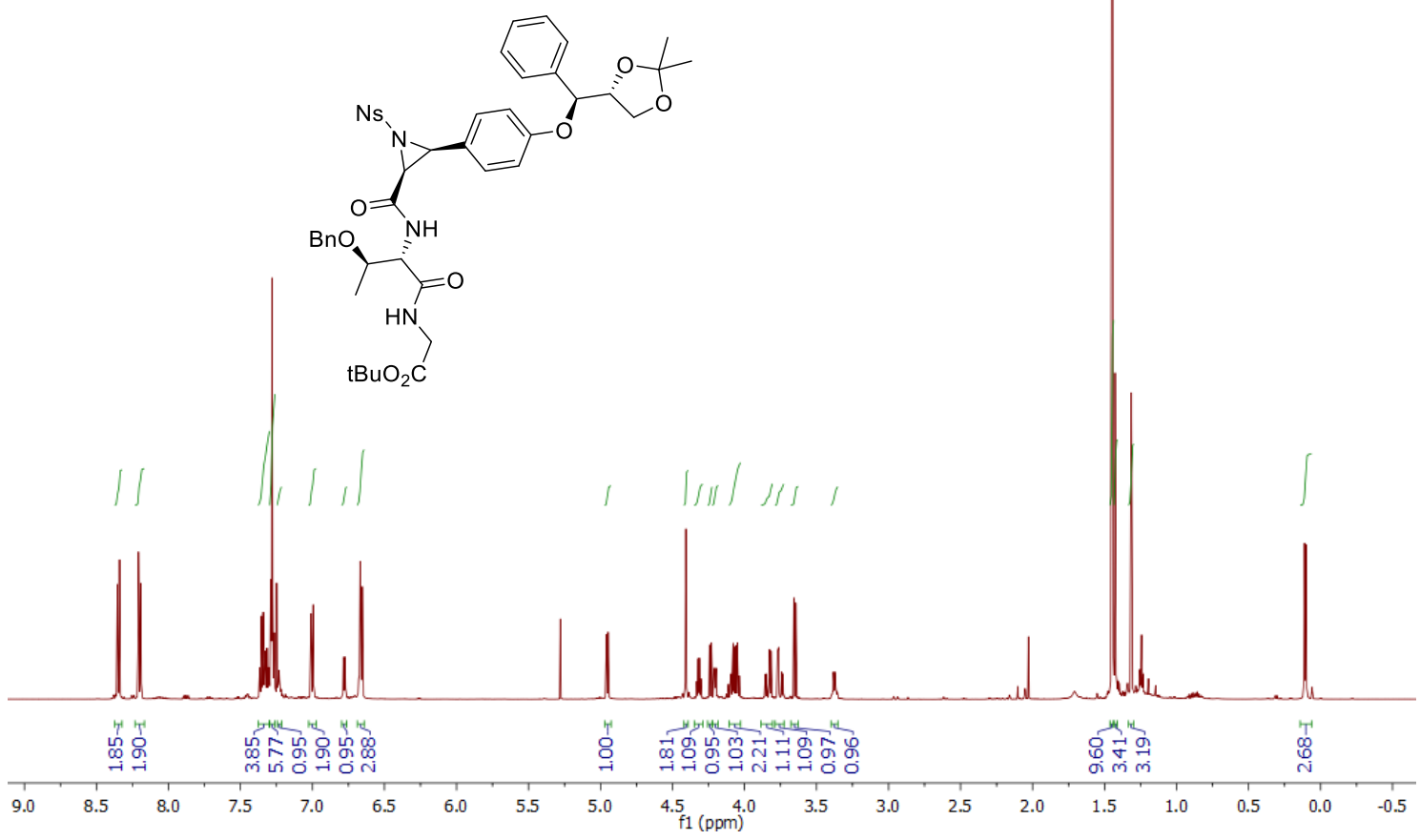

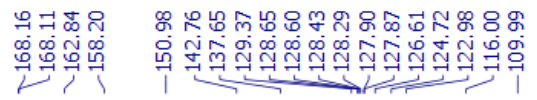

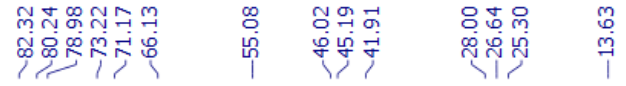<smiles>CC(Cc1ccccc1)C(NC(=O)C1C(c2ccc(OC(c3ccccc3)[C@H]3COC(C)(C)O3)cc2)N1SN)C(=O)NCC(=O)OC(C)(C)C</smiles>

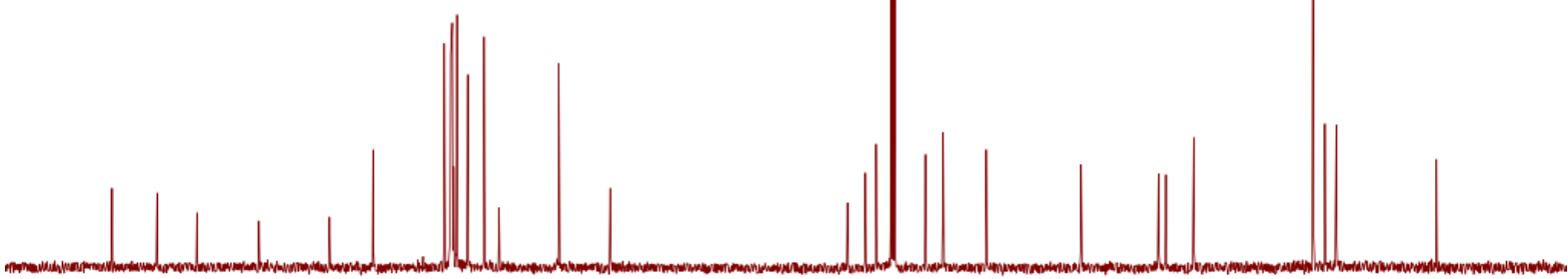

80

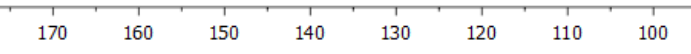

$120 \quad 110 \quad 100 \quad \stackrel{90}{9} 1(\mathrm{ppm})$

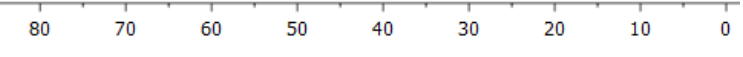


Figures S20-21: gCOSY and HSQC spectra of compound $11\left(500 \mathrm{MHz}, \mathrm{CDCl}_{3}\right)$
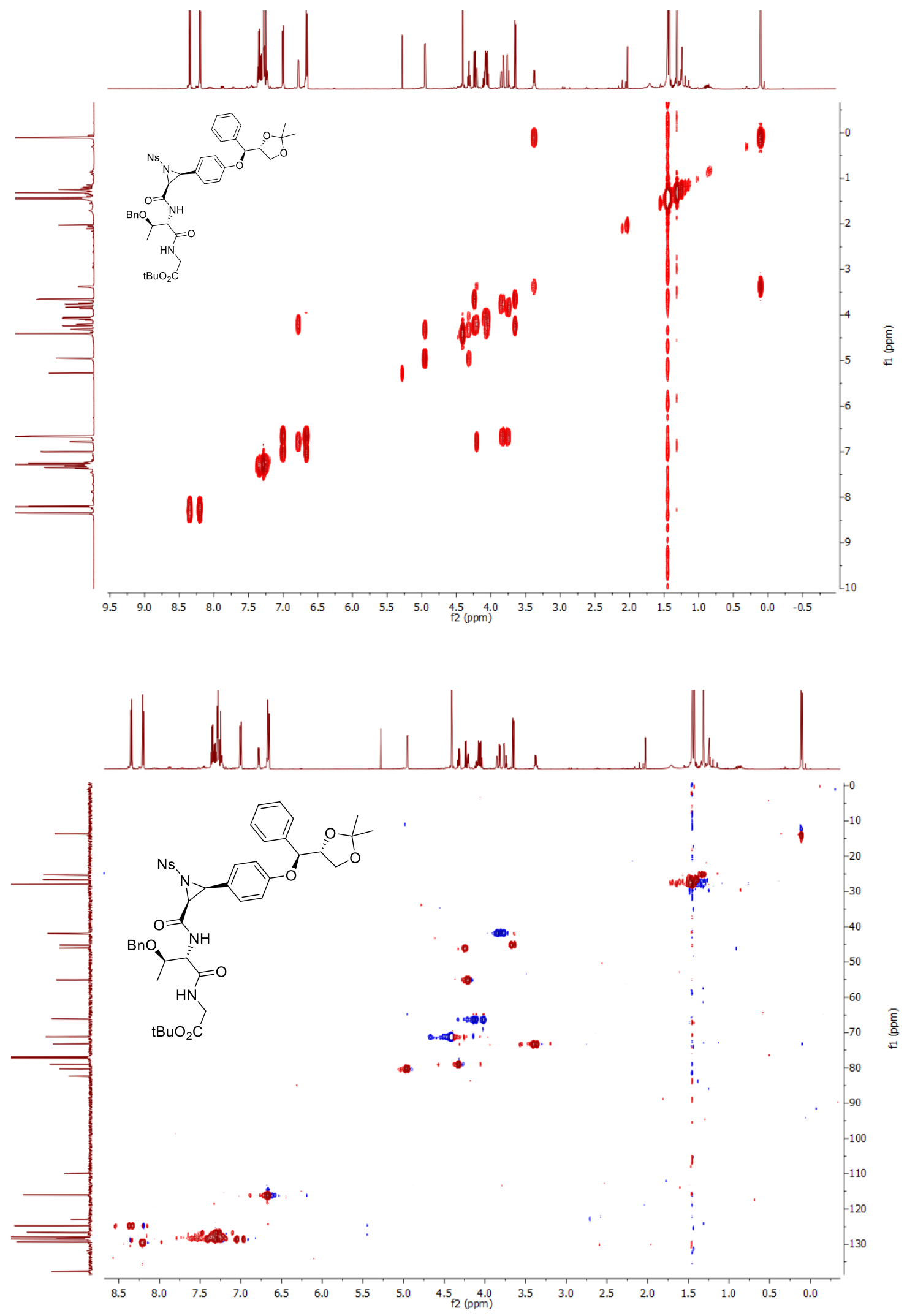
Figure S22: Mass spectrum of 11.

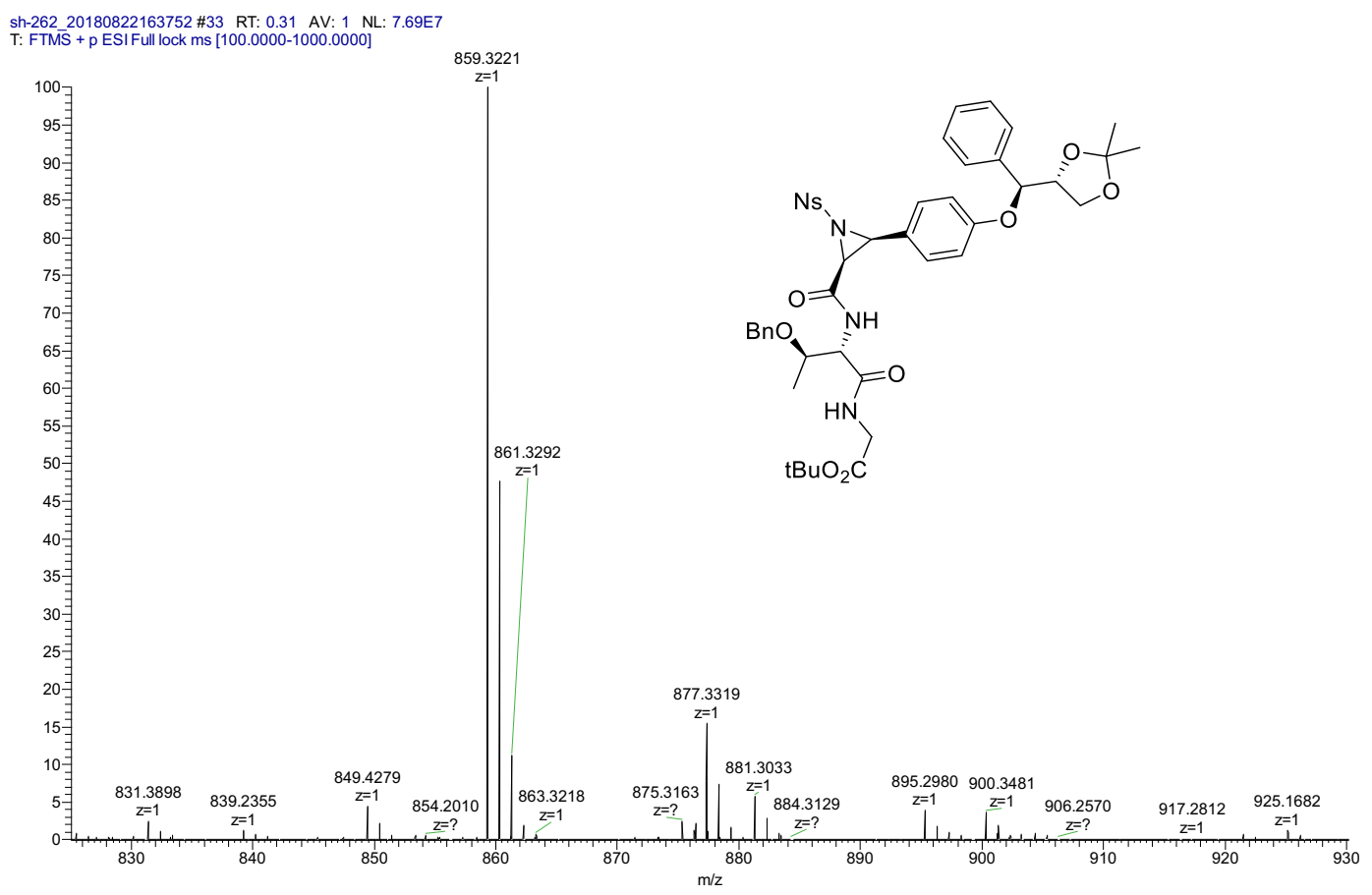

Figure S23: Mass spectrum of 13.

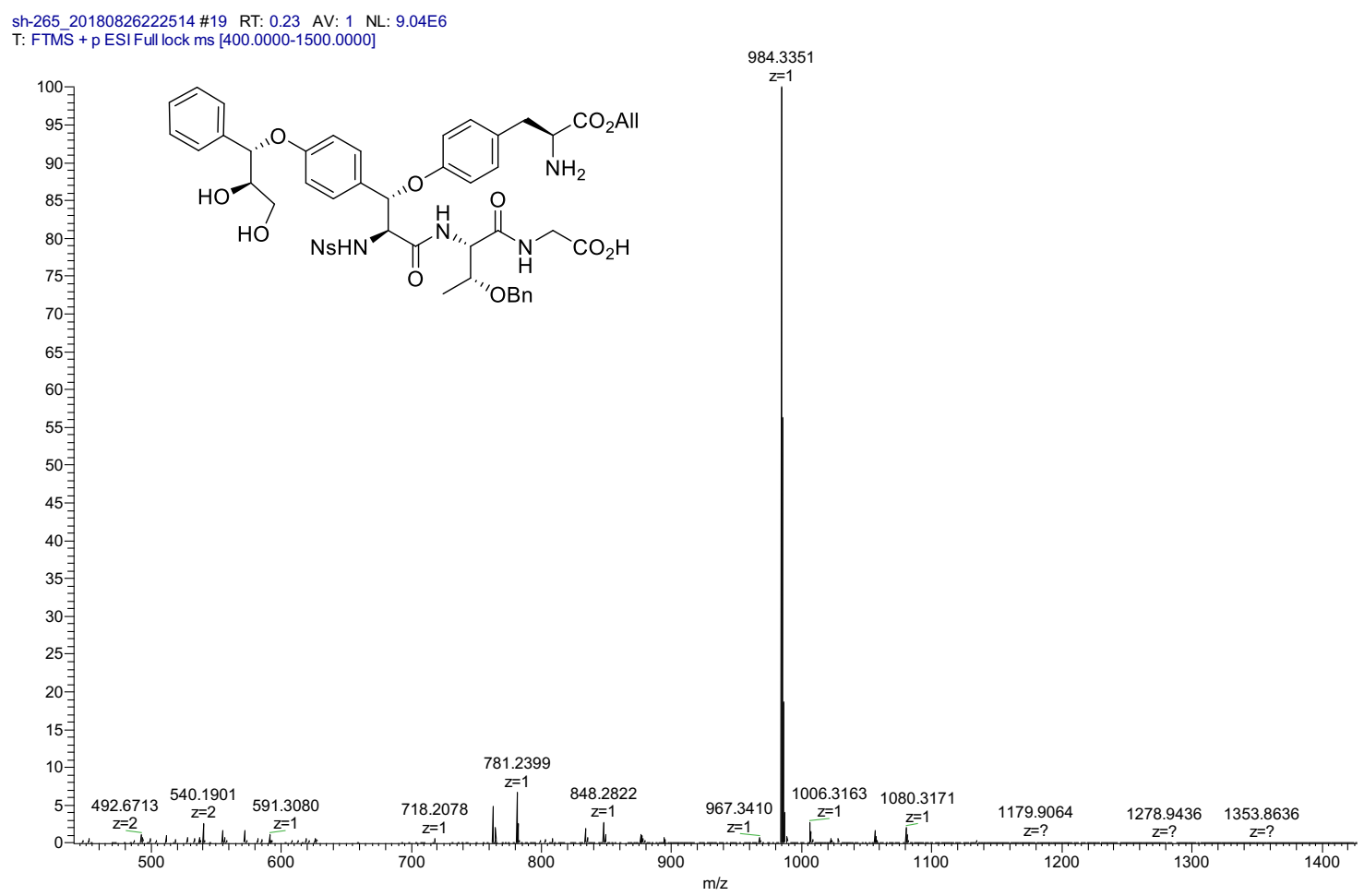


Figures S24-25: ${ }^{1} \mathrm{H}$ and ${ }^{13} \mathrm{C}$ NMR spectra of compound $14 \mathbf{a}$ and $14 \mathbf{b}\left(500 / 126 \mathrm{MHz}\right.$, acetone- $\left.d_{6}\right)$

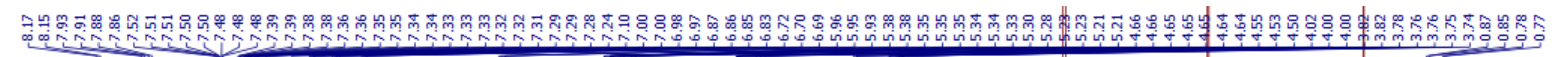

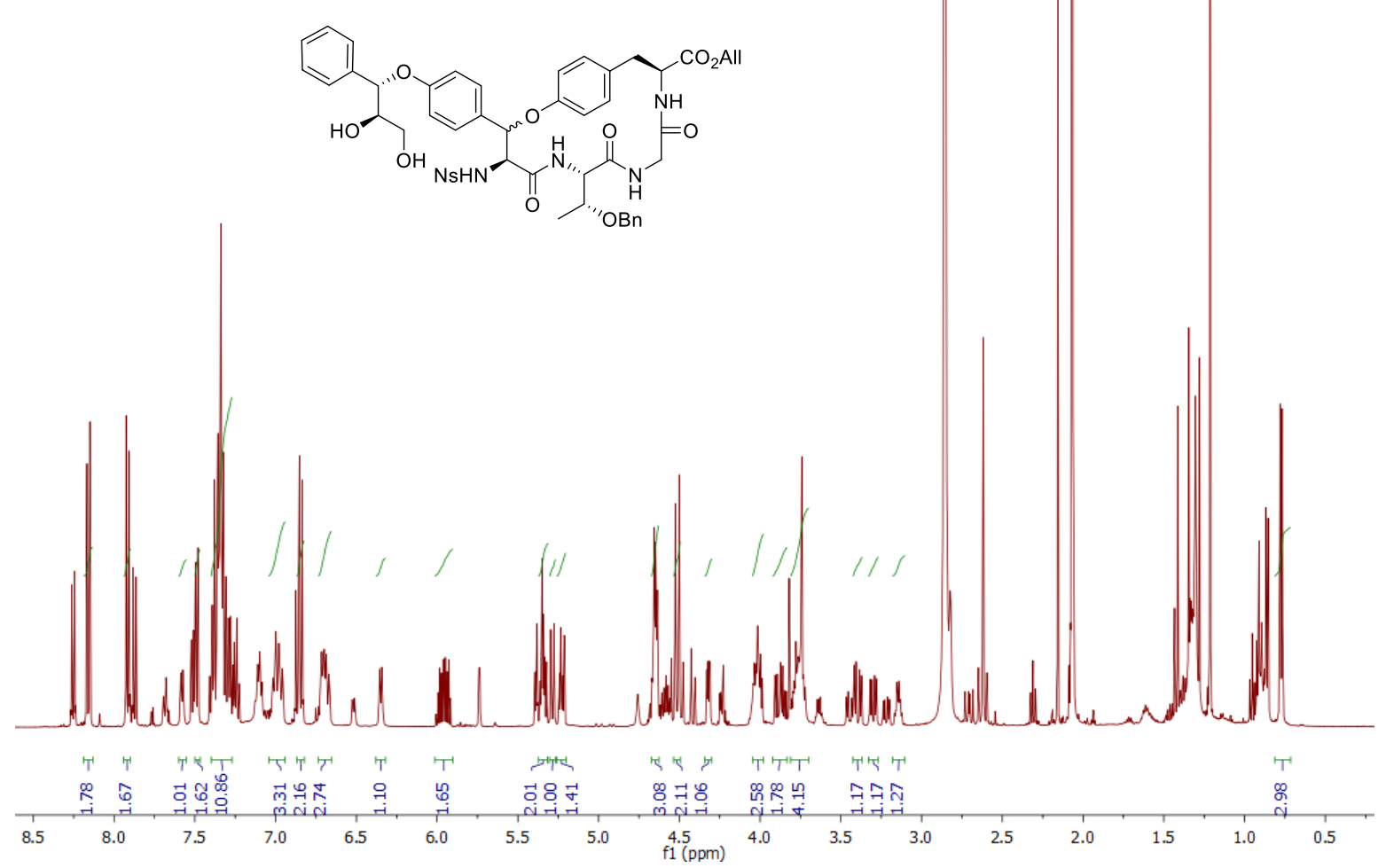

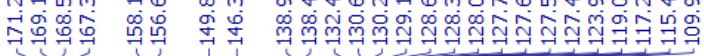

ก்ุ

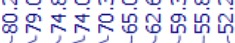

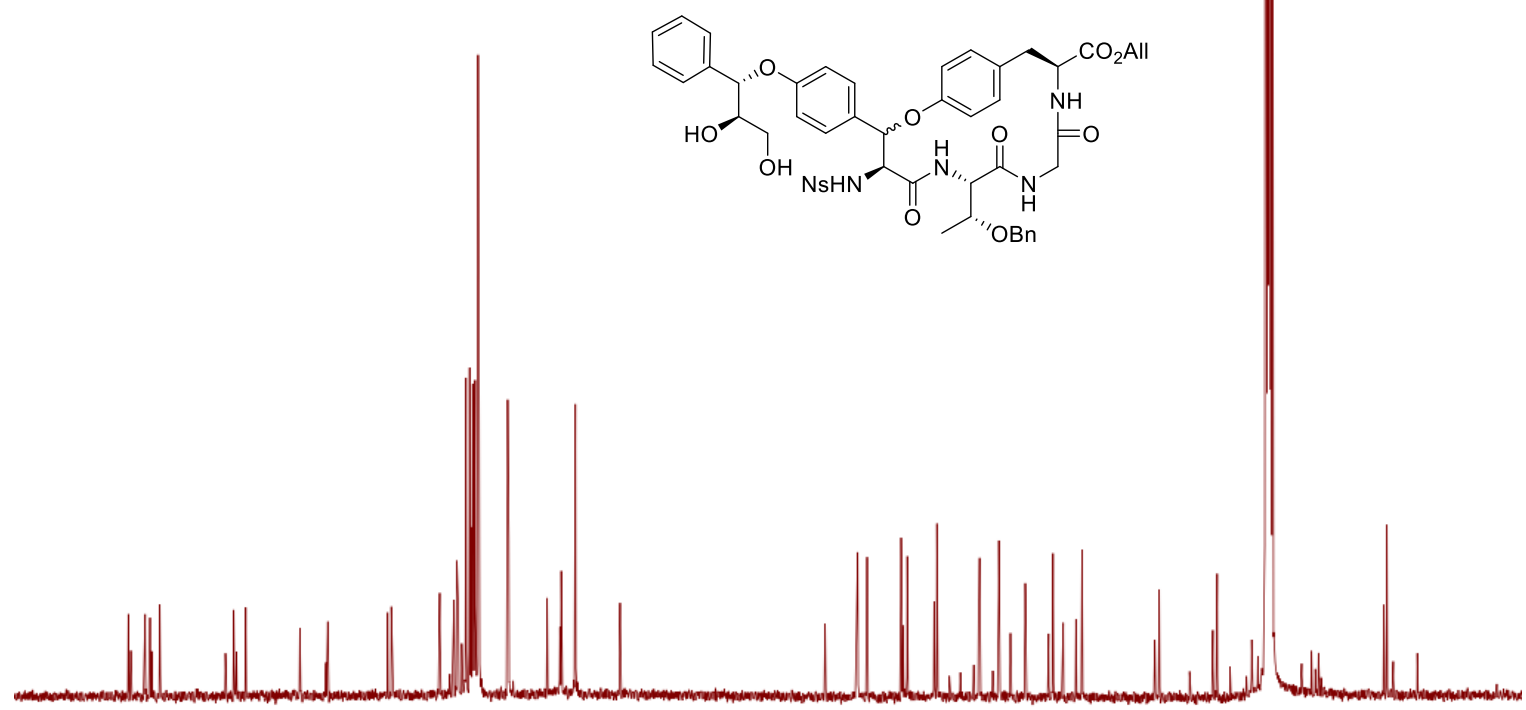

180 
Figure S26: Mass spectrum of $\mathbf{1 4}$.

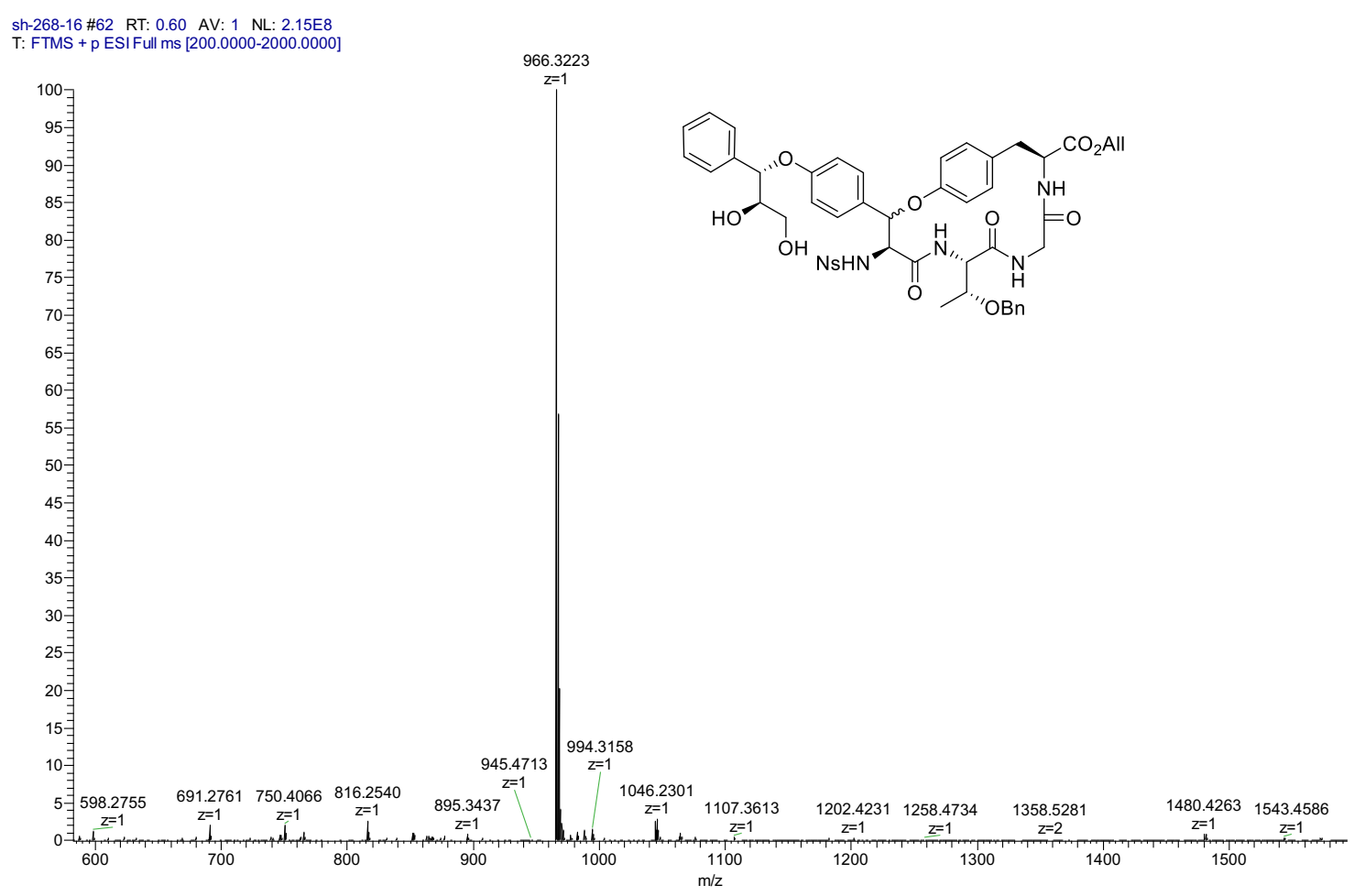

Figure S27: Mass spectrum of compound 15

36_20181125201353\#85 RT: 0.88 AV: 1 SB: 6 0.03-0.09 NL: 8.94E6 T: FTMS + p ESI Full lock ms [400.0000-1500.0000]

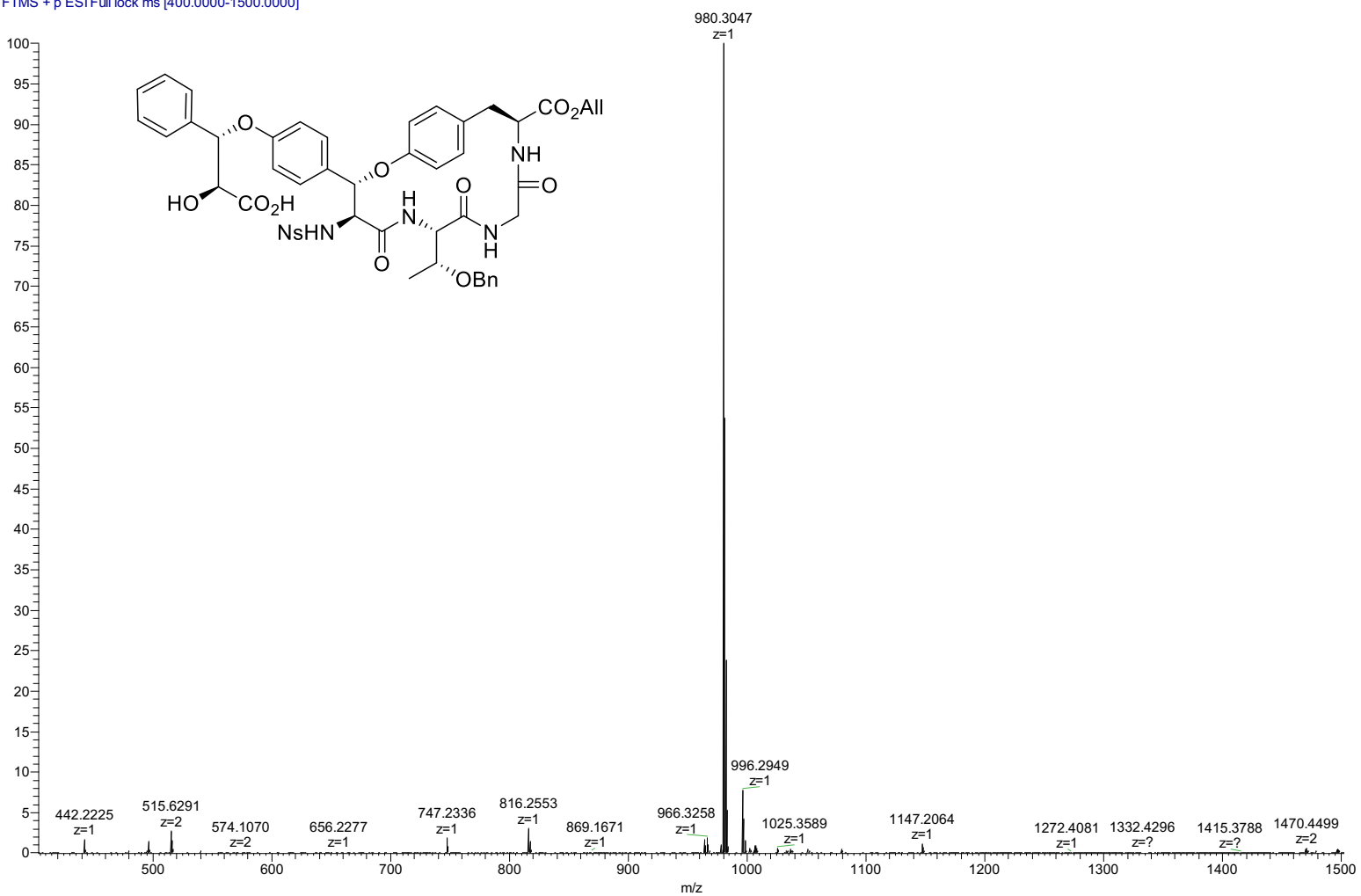


Figures S28-29: ${ }^{1} \mathrm{H}$ and ${ }^{13} \mathrm{C}$ NMR spectra of compound $16\left(500 / 126 \mathrm{MHz}\right.$, DMSO- $\left.d_{6}\right)$

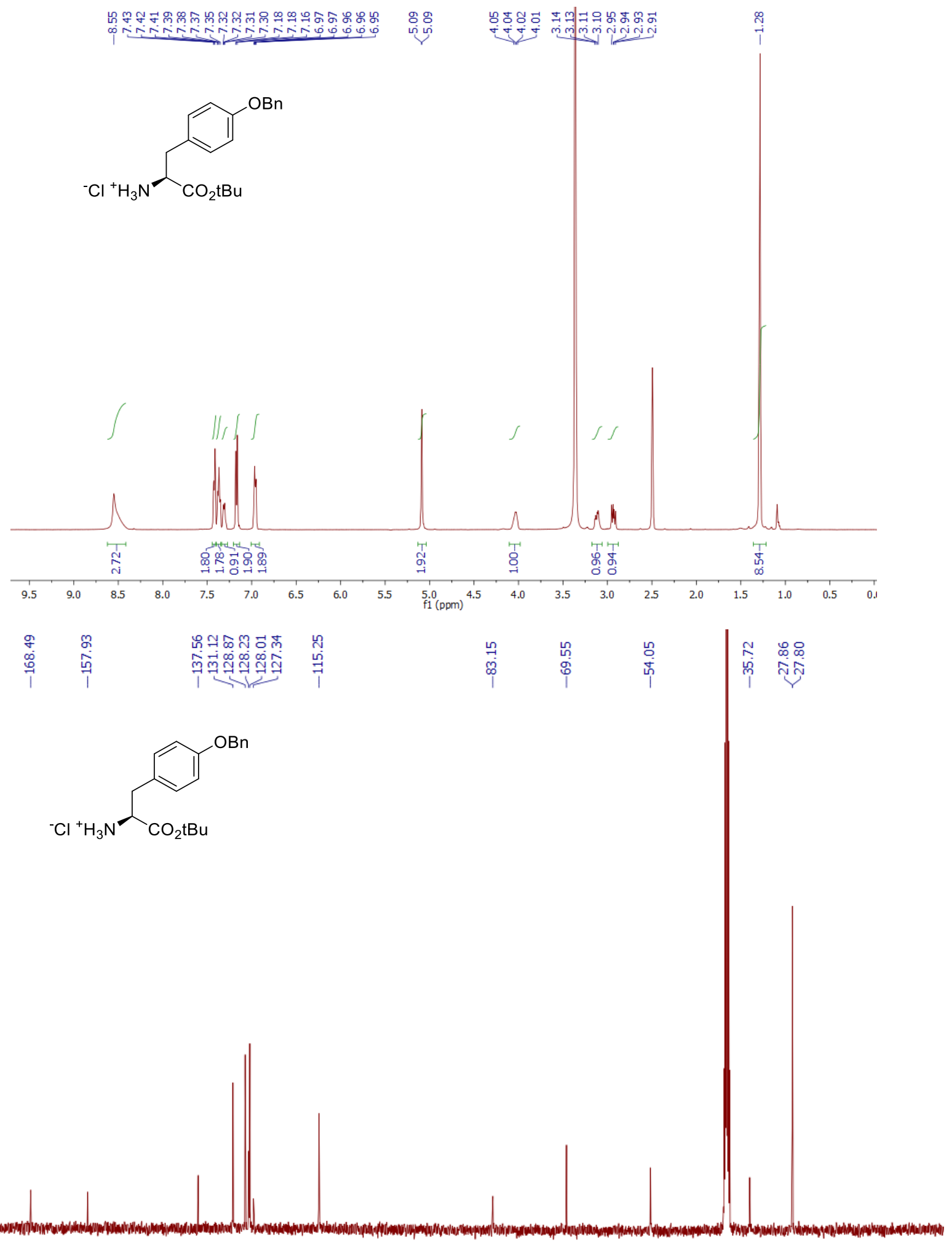

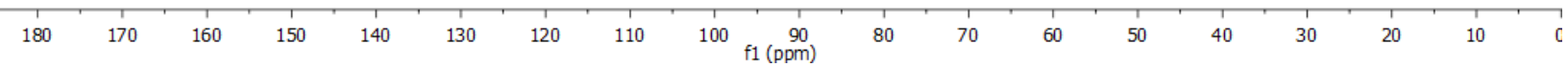


Figures S30-31: ${ }^{1} \mathrm{H}$ and ${ }^{13} \mathrm{C}$ NMR spectra of compounds $17 \mathbf{a}$ and $\mathbf{1 7 b}\left(500 / 126 \mathrm{MHz}\right.$, acetone- $\left.d_{6}\right)$

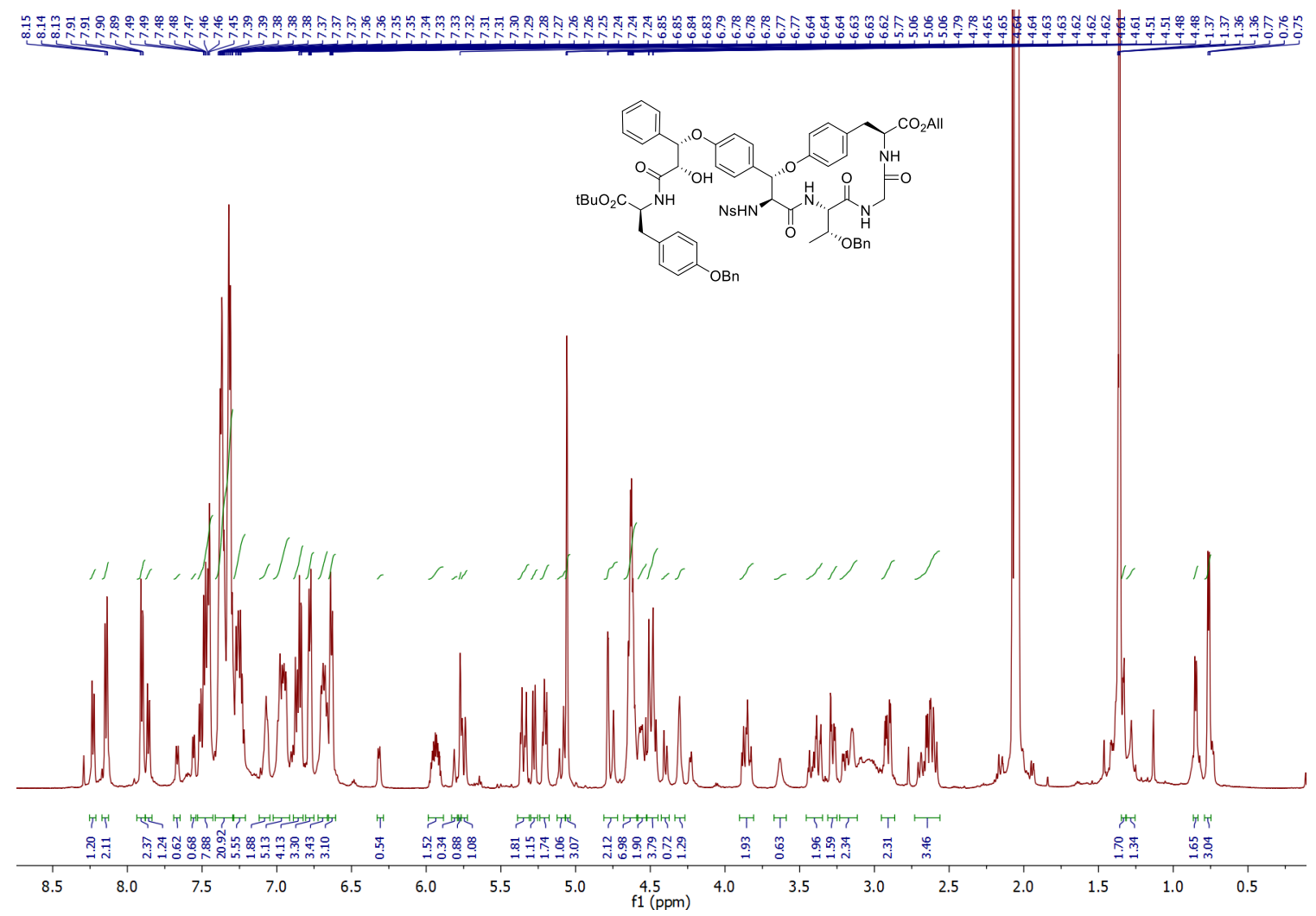

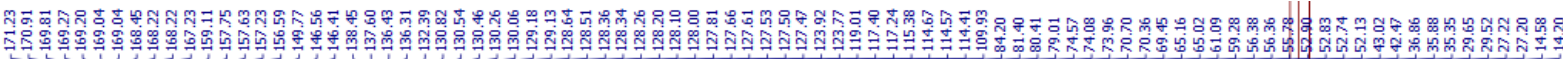

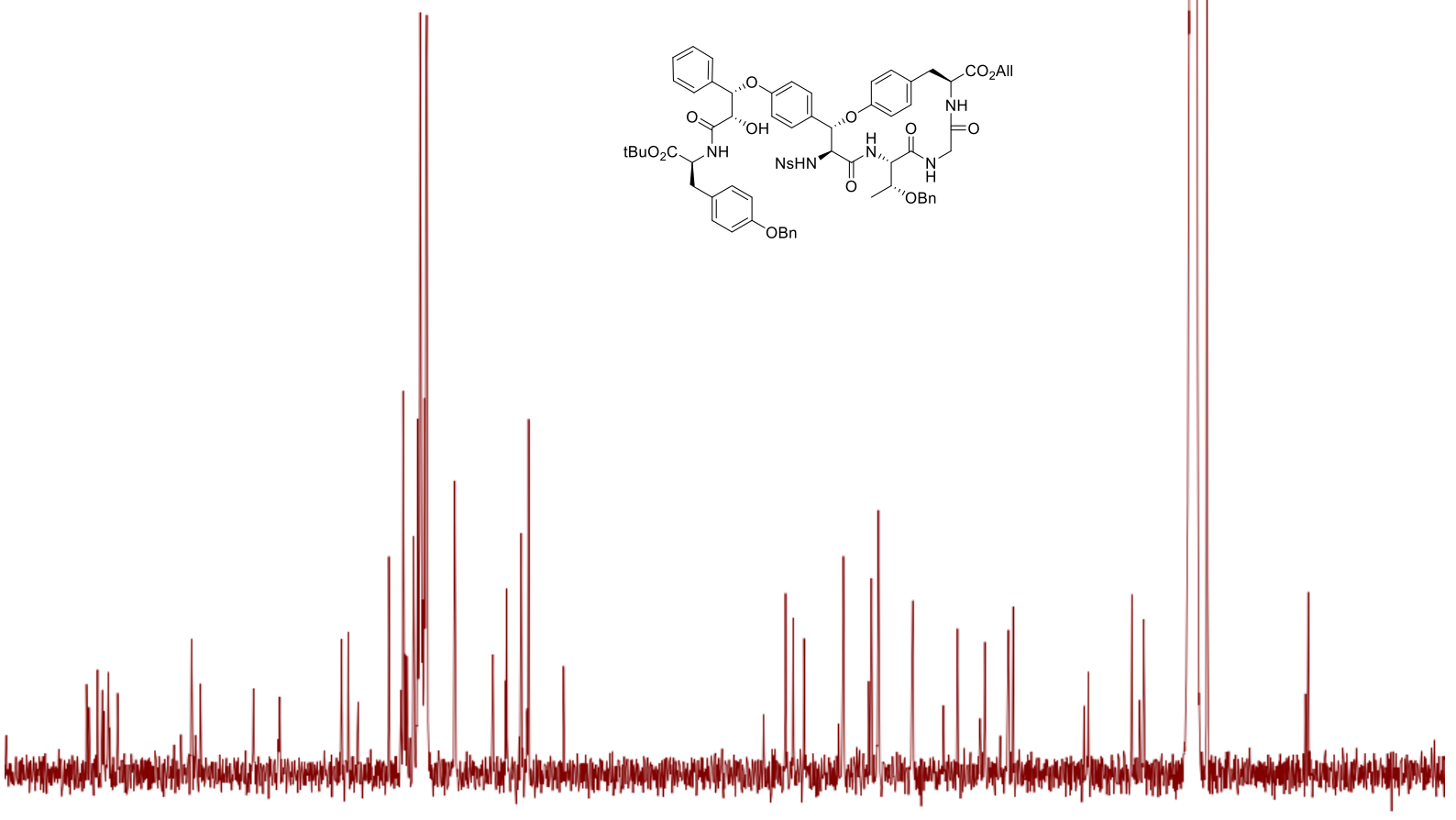

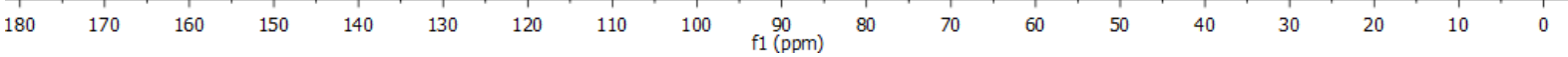


Figures S32: gCOSY spectrum of compound $17 \mathbf{a}$ and $17 \mathbf{b}\left(500 \mathrm{MHz}\right.$, acetone- $\left.d_{6}\right)$

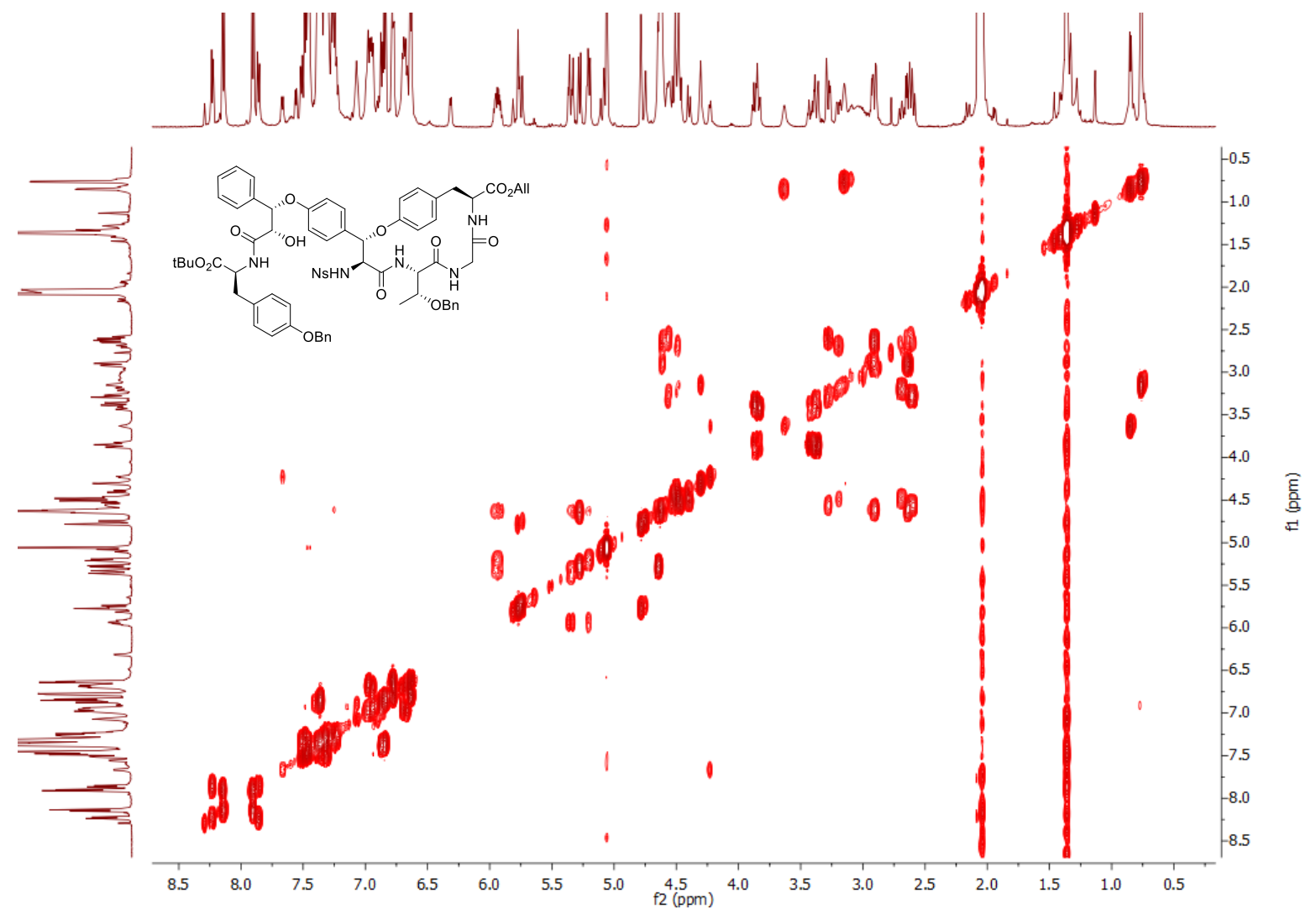

Figures S33: Mass spectrum of $\mathbf{1 8}$

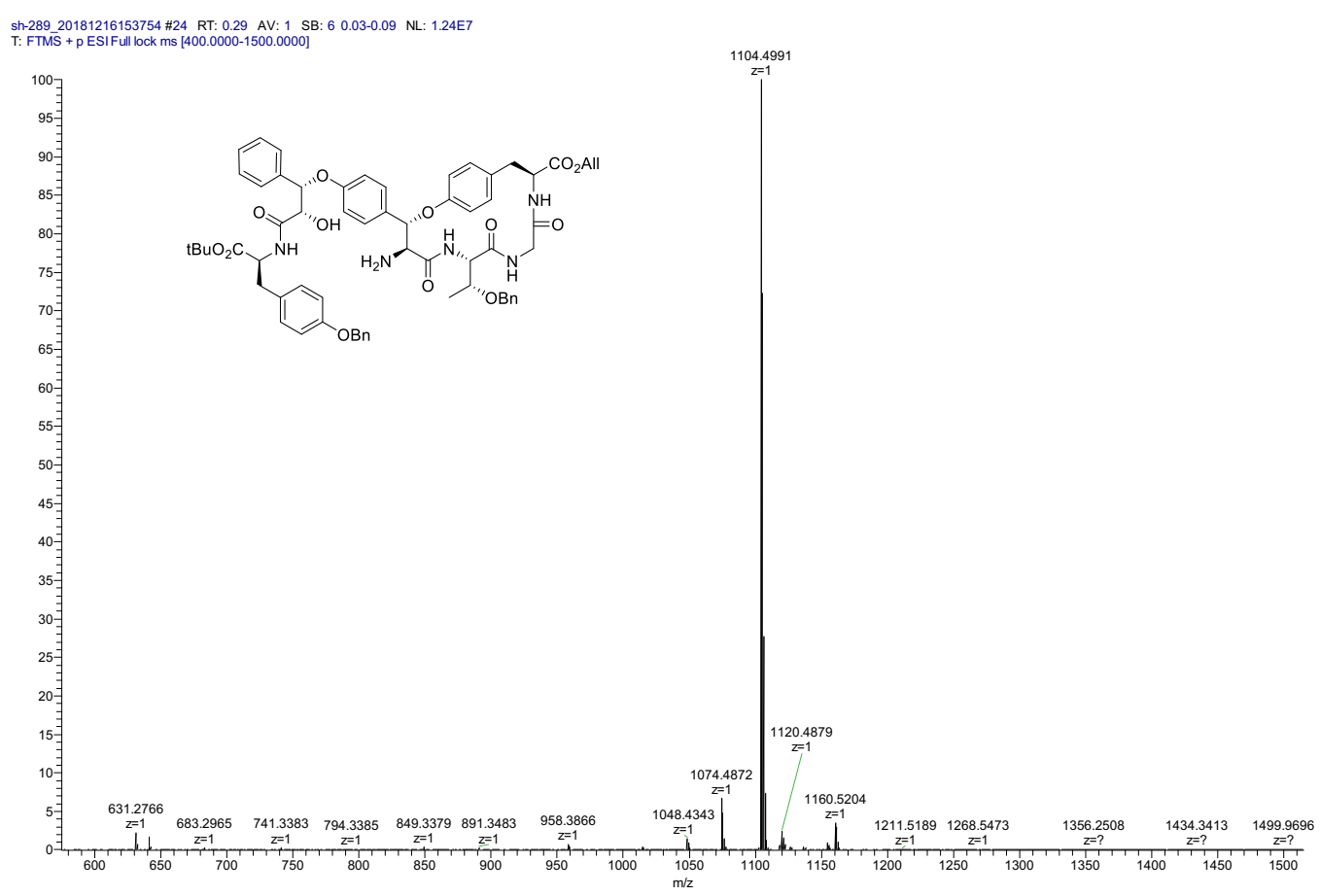


Figures S34: Mass spectrum of bicyclic compound 19

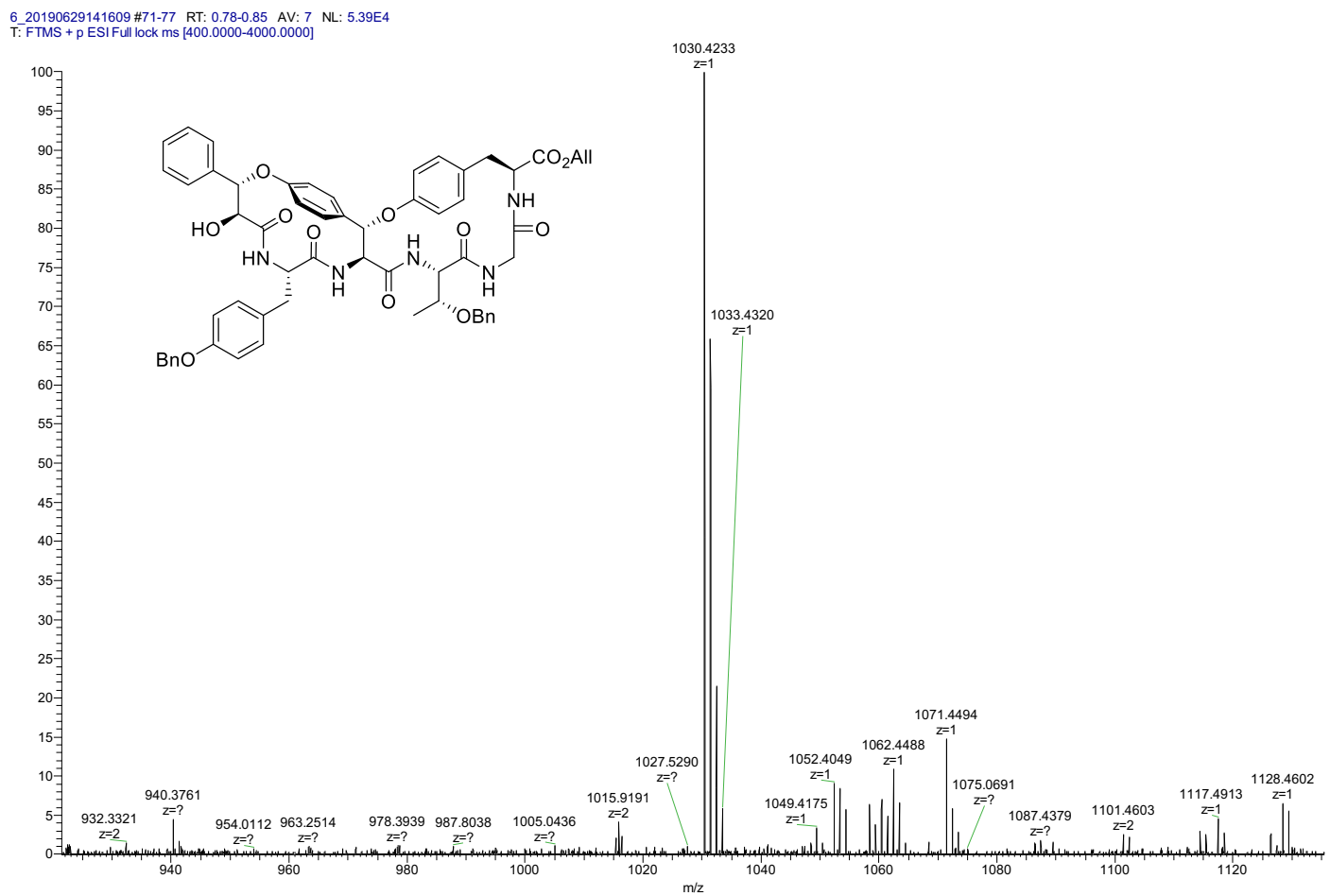

Figures S35: Mass spectrum of bicyclic compound 20

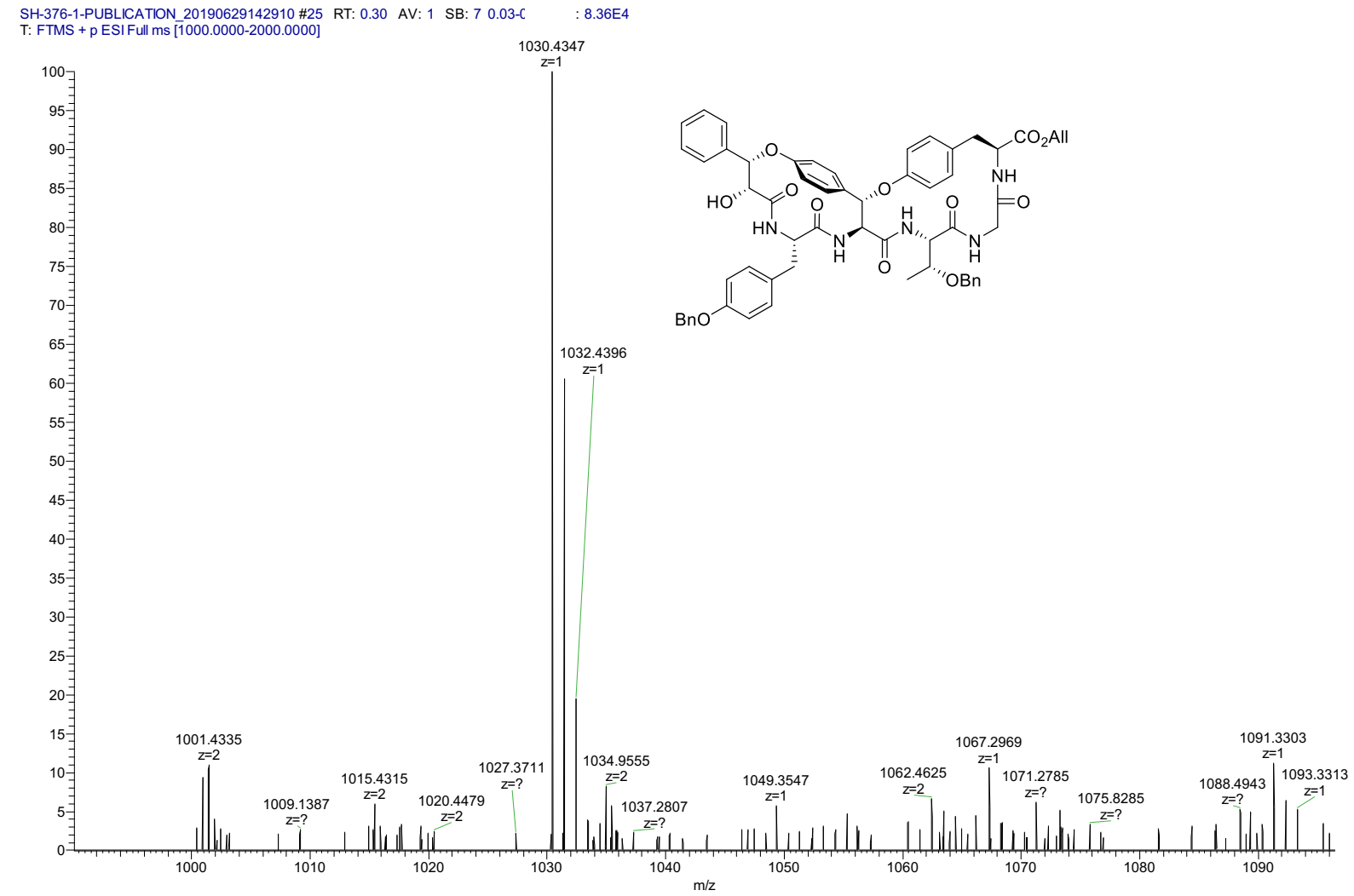


Figures S36: Mass spectrum of cyclodimerized compound

SH-376 $20190626180013 \# 7$ RT: 0.08 AV: 1 NL: 2.93E5

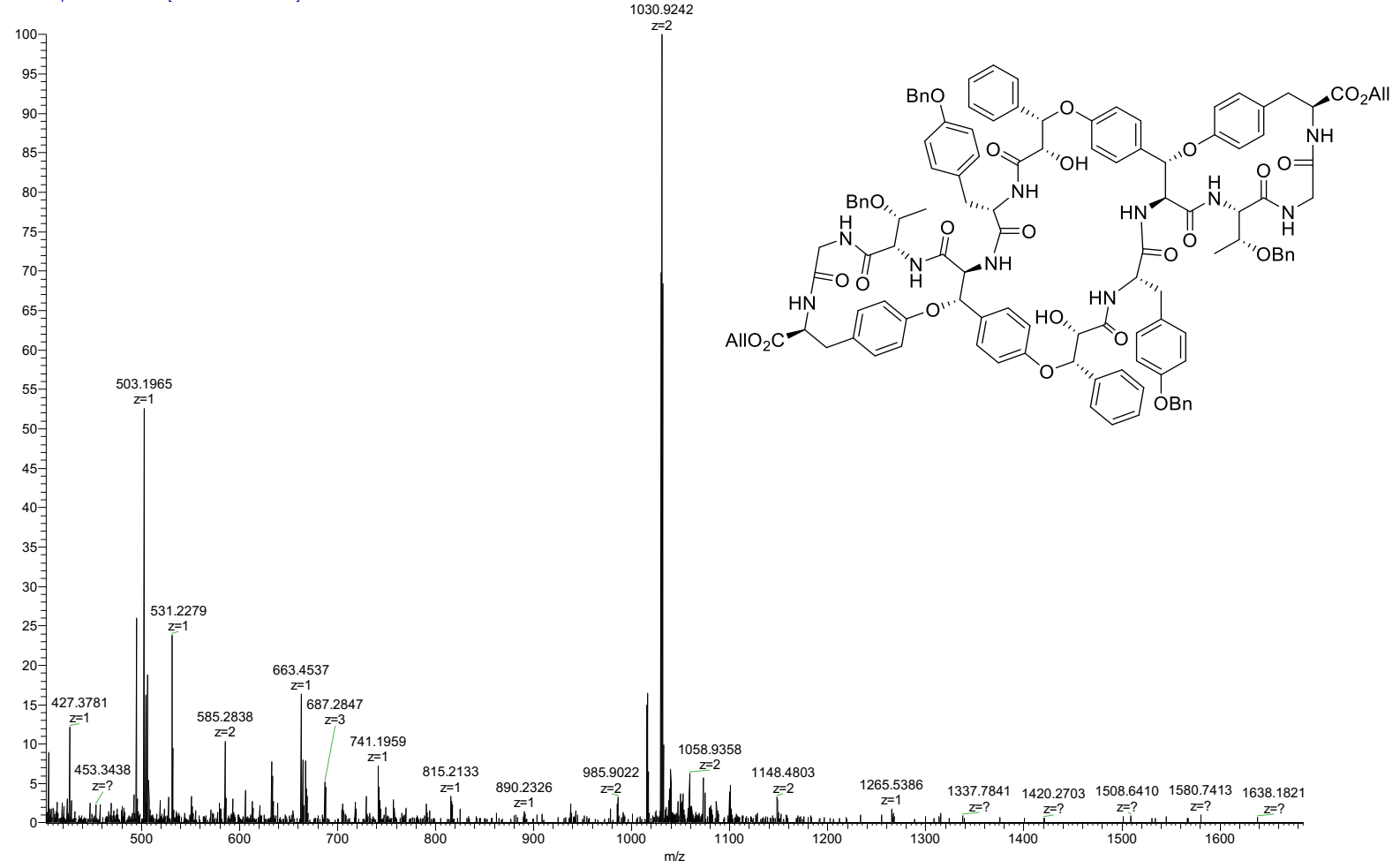


Figure S37: ${ }^{1} \mathrm{H}$ NMR spectrum of Boc-Thr(All)-OH S2 (500 MHz, $\left.\mathrm{CDCl}_{3}\right)$

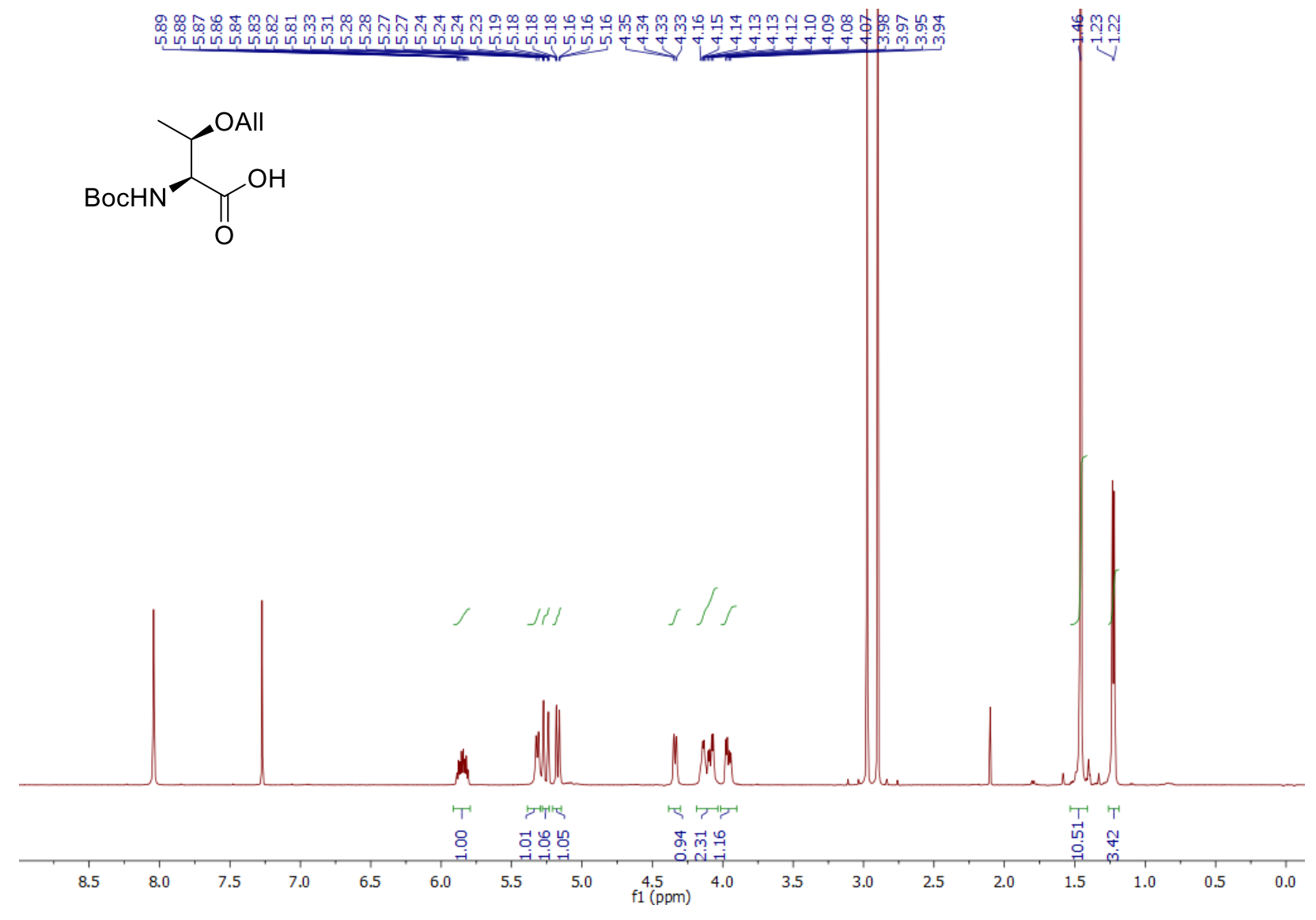


Figures S38-39: ${ }^{1} \mathrm{H}$ and ${ }^{13} \mathrm{C}$ NMR spectra of Boc-Thr(All)-Gly-OtBu $\mathbf{S 3}\left(600 / 151 \mathrm{MHz}, \mathrm{CDCl}_{3}\right)$

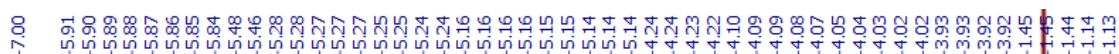

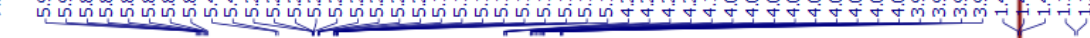<smiles>CO[C@@H](C)[C@H](NC(=O)OCc1ccccc1)C(=O)NCC(=O)OC(C)(C)C</smiles>

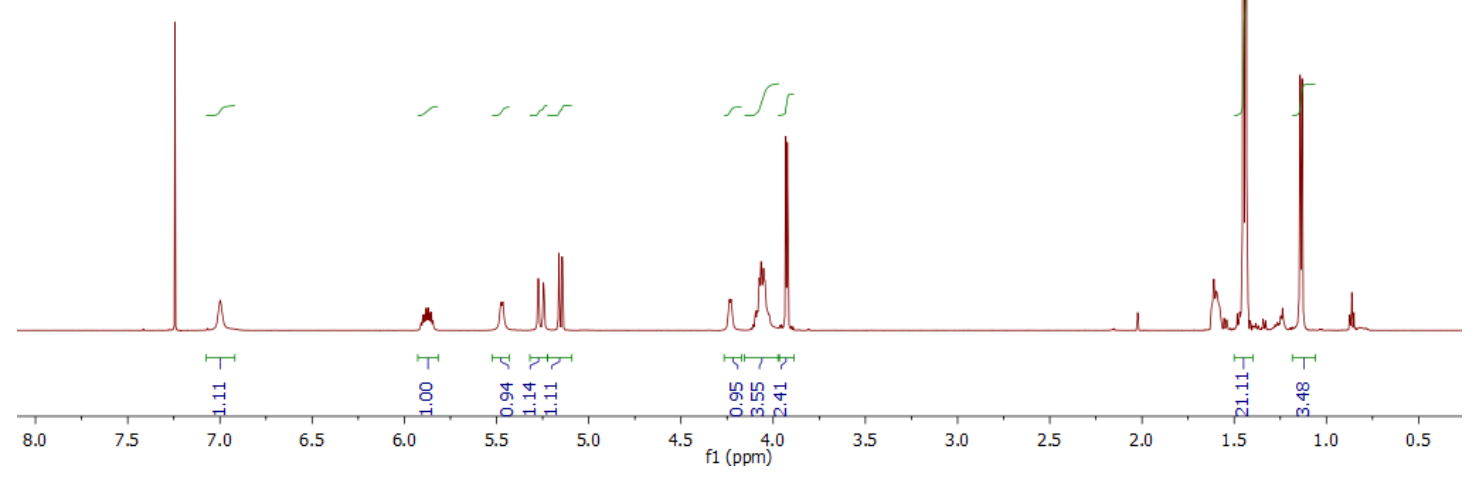

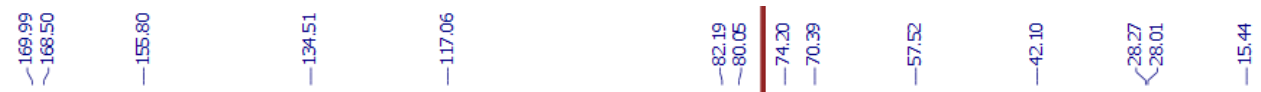<smiles>CCC(C)OC(=O)CNC(=O)[C@@H](NC(C)(C)C)C(C)O[Na]</smiles>

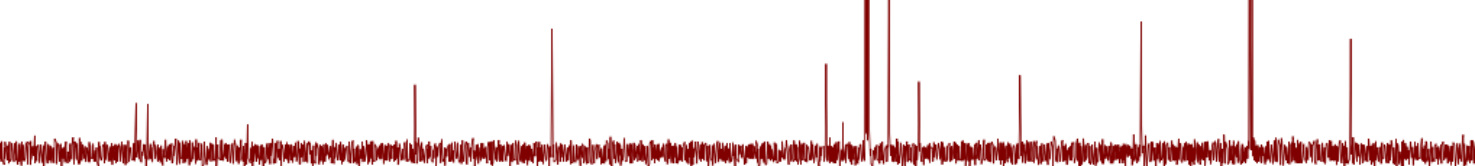

$\begin{array}{lllllllll}180 & 170 & 160 & 150 & 140 & 130 & 120 & 110 & 100 \\ \mathrm{f} 1(\mathrm{ppm})\end{array}$ 
Figures S40-41: ${ }^{1} \mathrm{H}$ and ${ }^{13} \mathrm{C}$ NMR spectra of Thr(All)-Gly-OtBu $21\left(600 / 151 \mathrm{MHz}, \mathrm{CDCl}_{3}\right)$
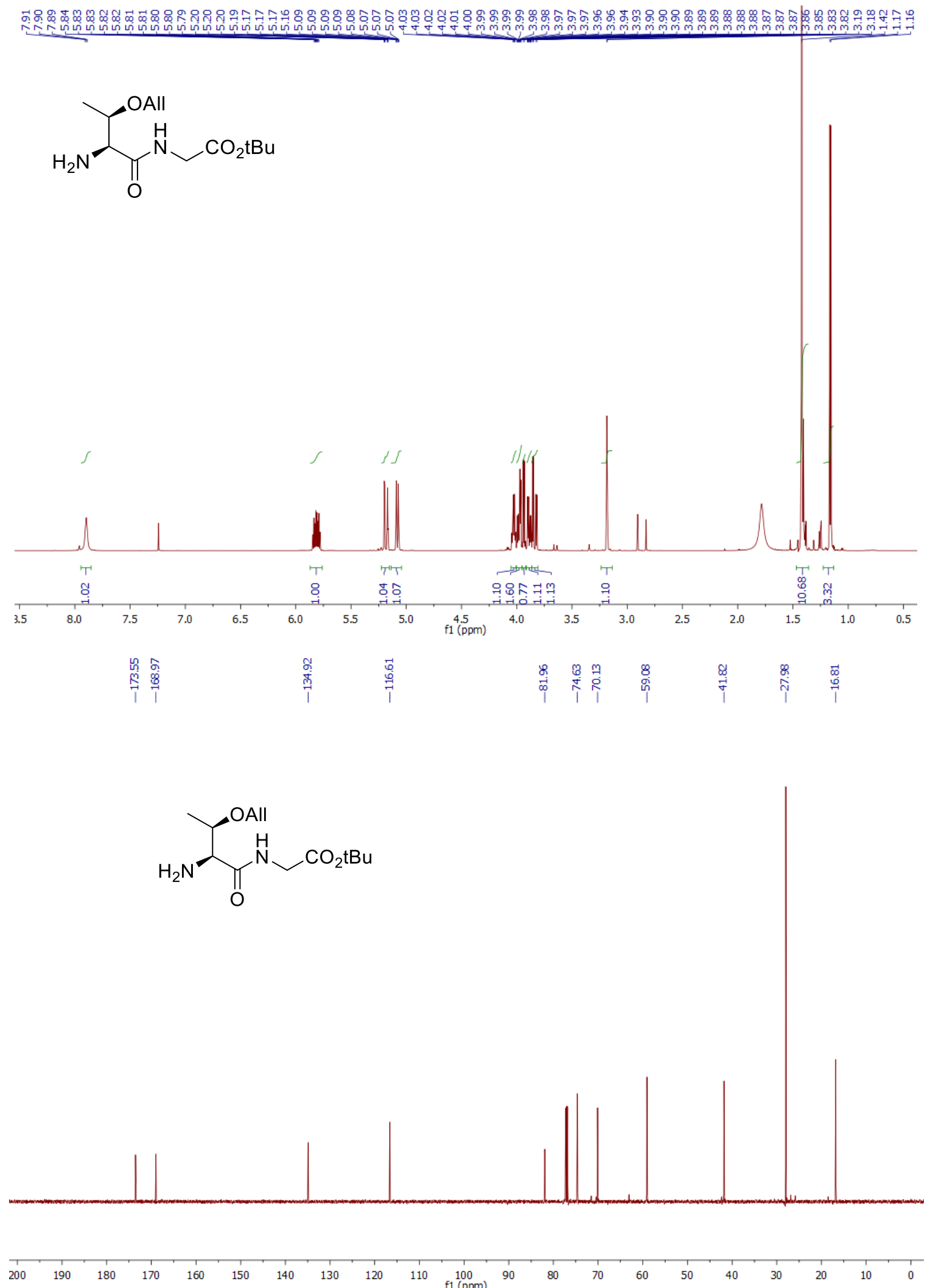
Figures S42-43: ${ }^{1} \mathrm{H}$ and ${ }^{13} \mathrm{C}$ NMR spectra of tripeptide $\mathbf{S} 4\left(600 / 151 \mathrm{MHz}, \mathrm{CDCl}_{3}\right)$
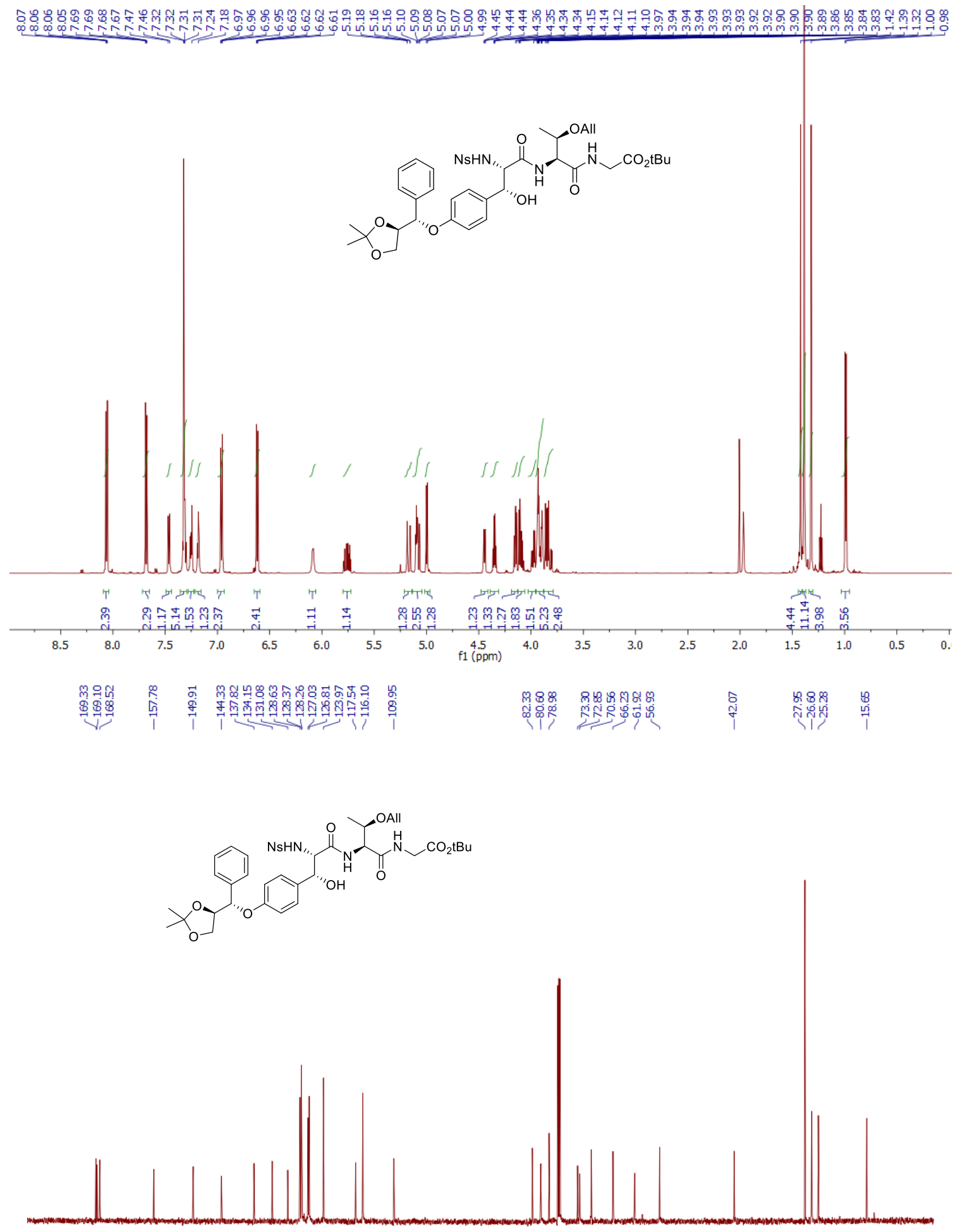
Figure S44: Mass spectrum of S4.

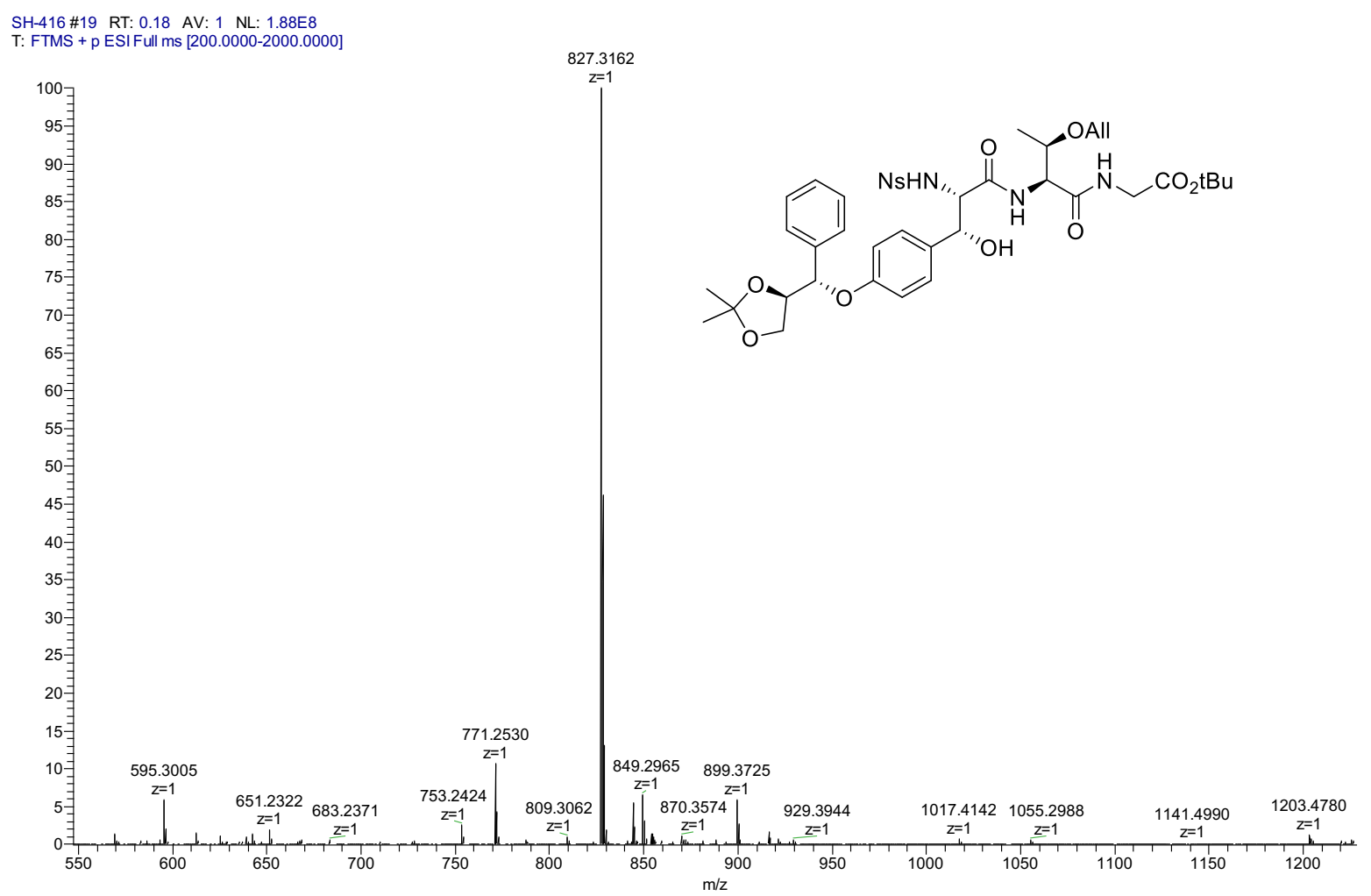


Figures S45-46: ${ }^{1} \mathrm{H}$ NMR and ${ }^{13} \mathrm{C}$ NMR spectra of aziridine $22\left(500 / 126 \mathrm{MHz}, \mathrm{CDCl}_{3}\right)$
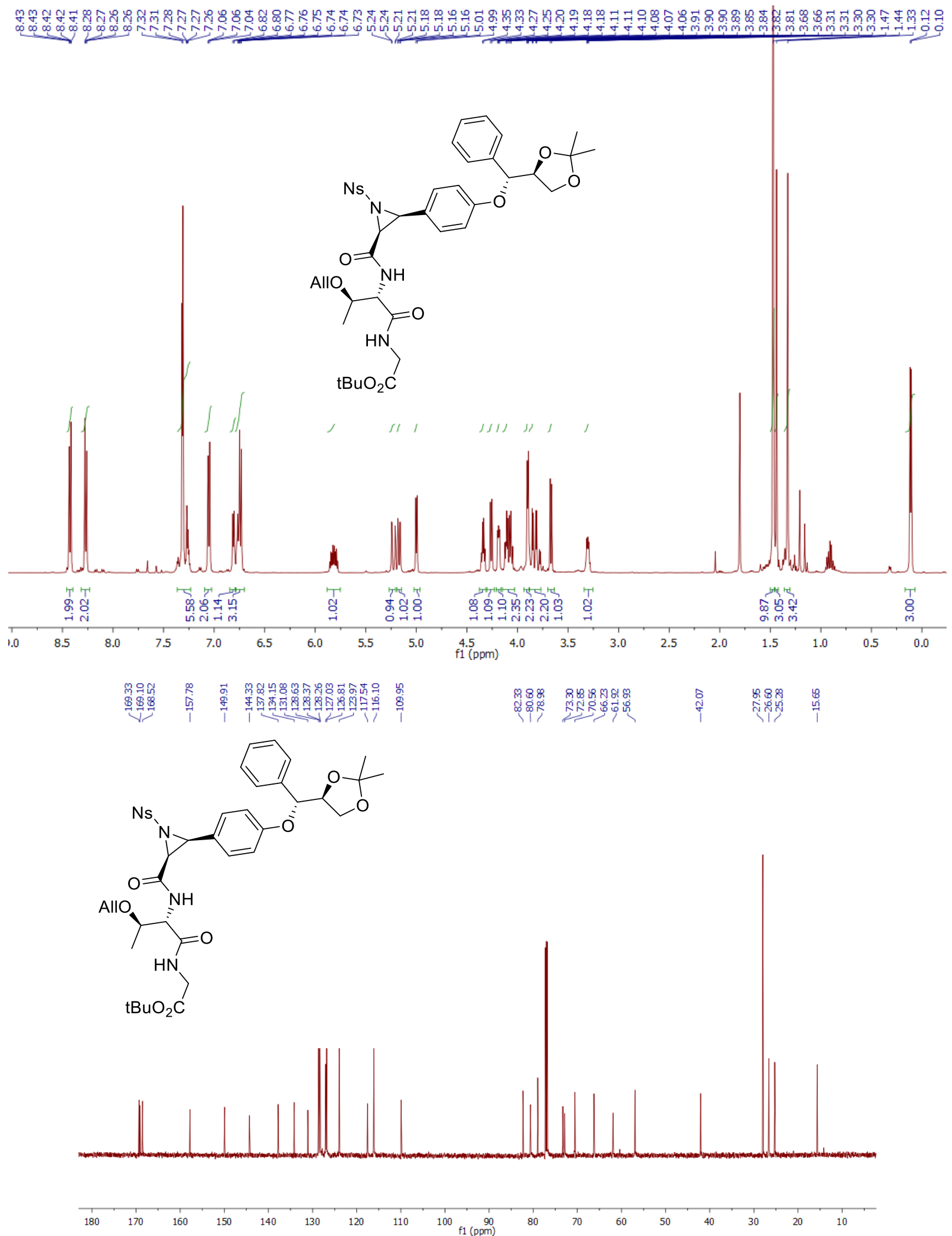
Figure S47: Mass spectrum of 22.

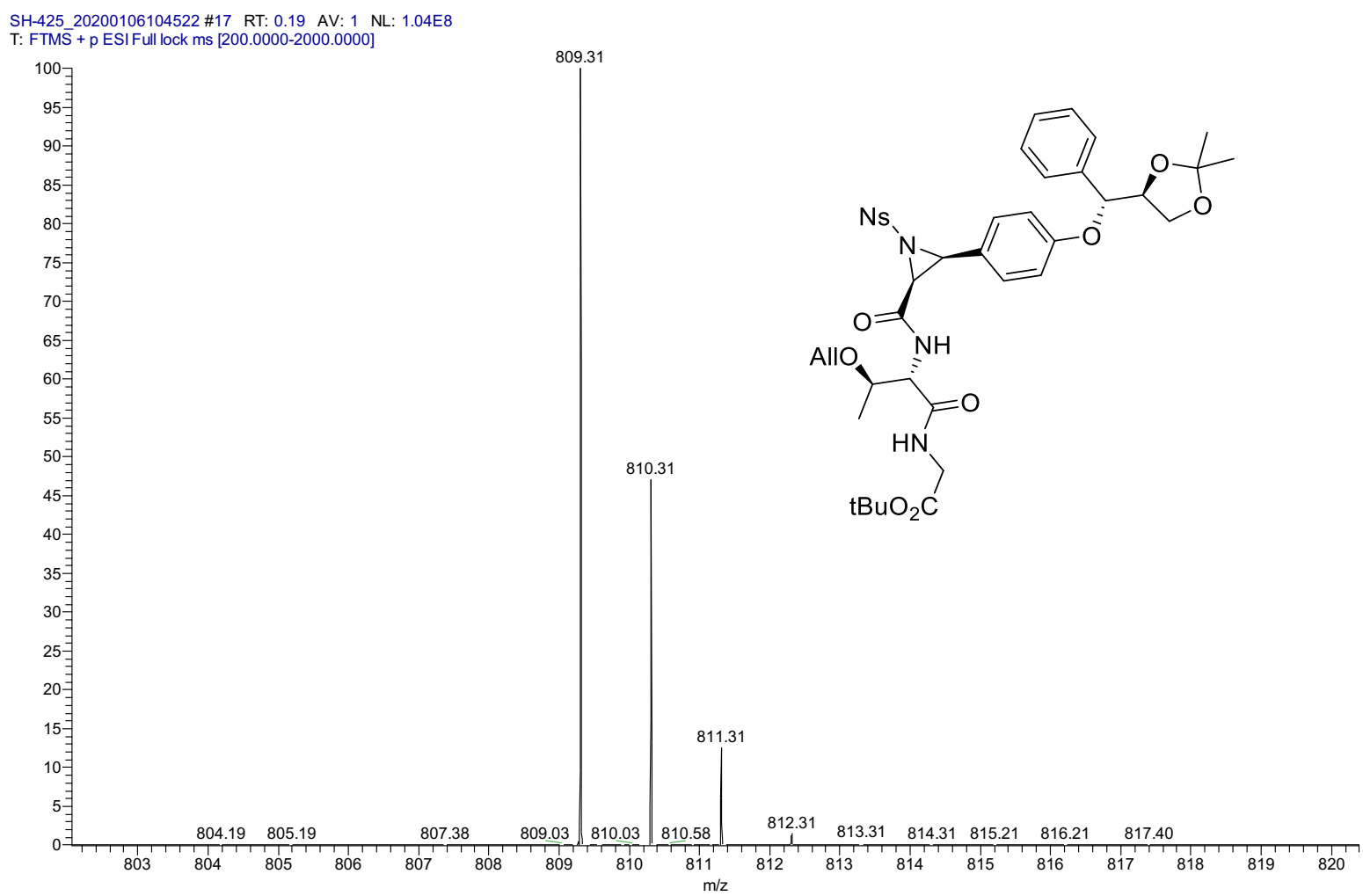


Figures S48-49: ${ }^{1} \mathrm{H}$ and ${ }^{13} \mathrm{C}$ NMR spectra of aziridine $23 a\left(500 / 126 \mathrm{MHz}, \mathrm{CDCl}_{3}\right)$

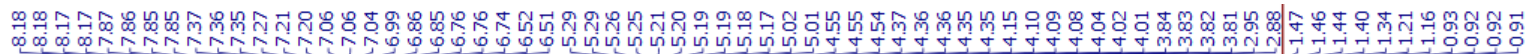

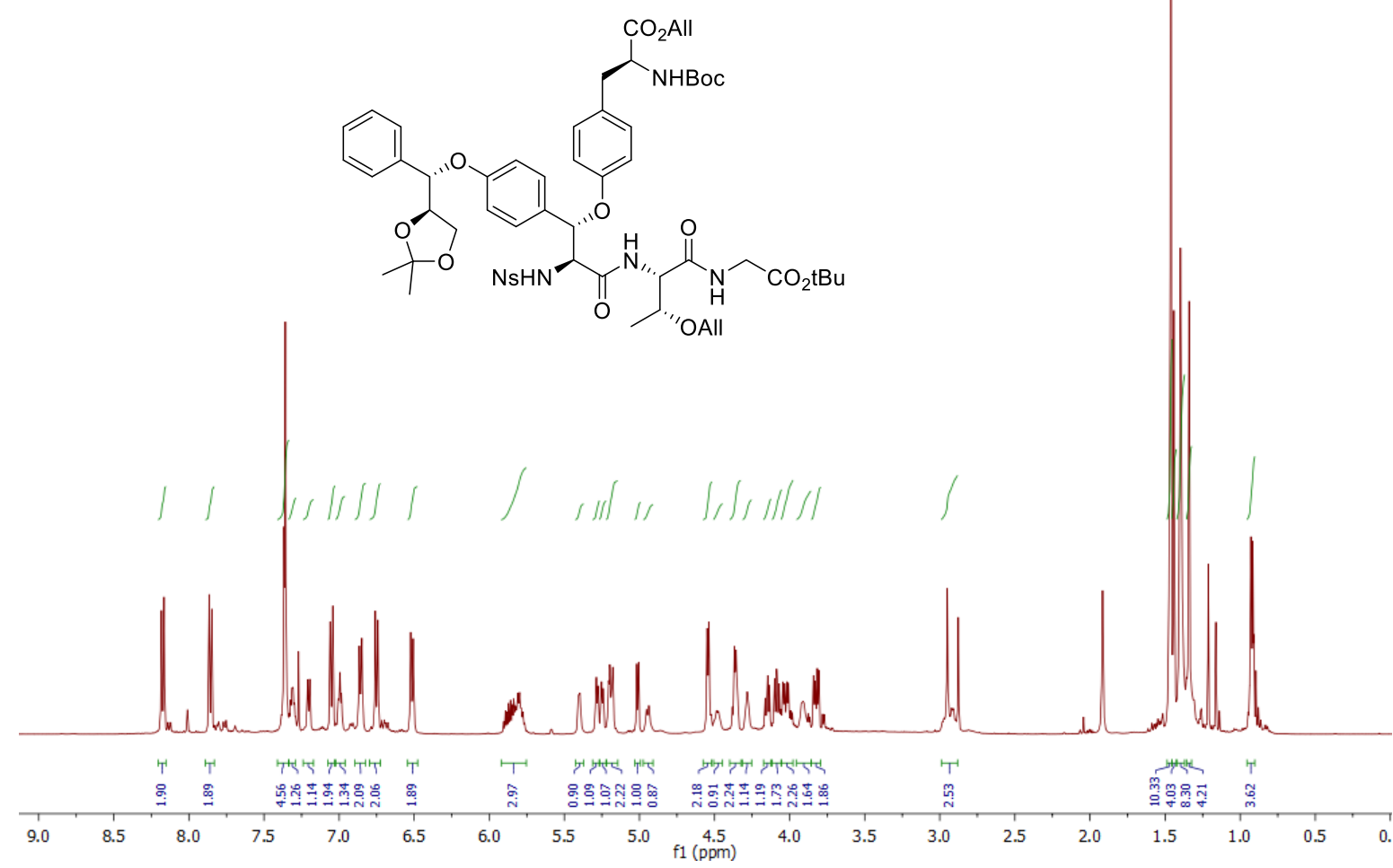

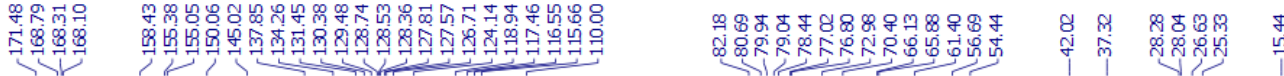

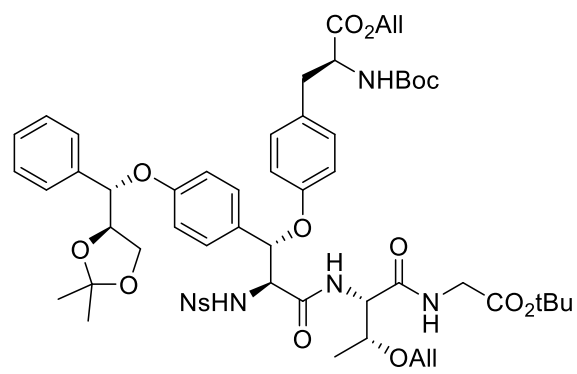

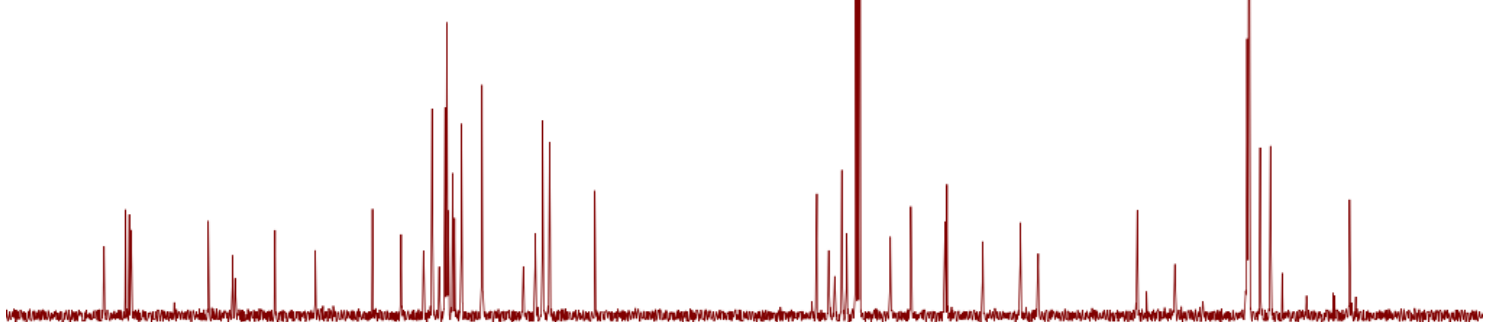

180
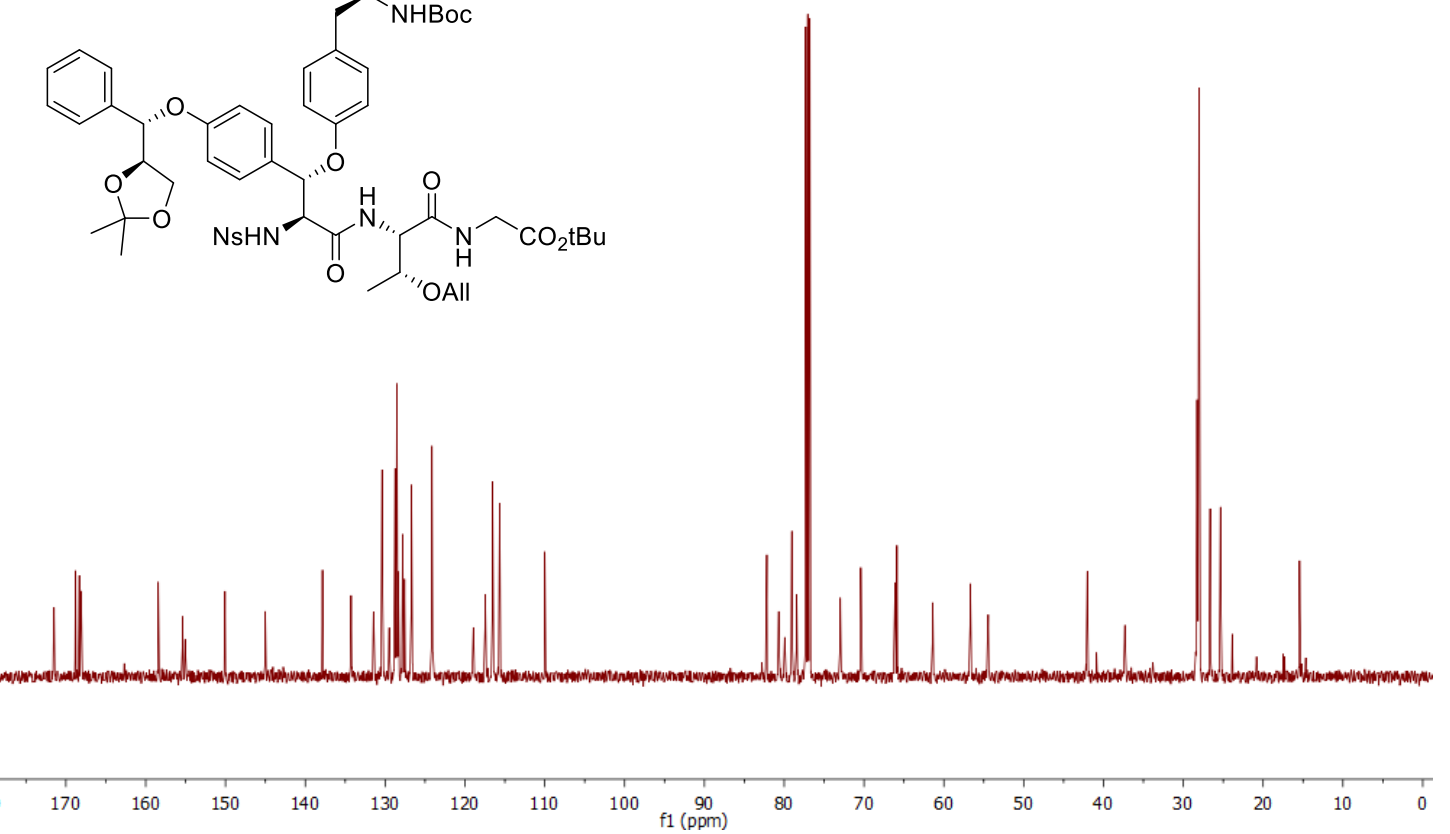
Figure S50: Mass spectrum of 23a.

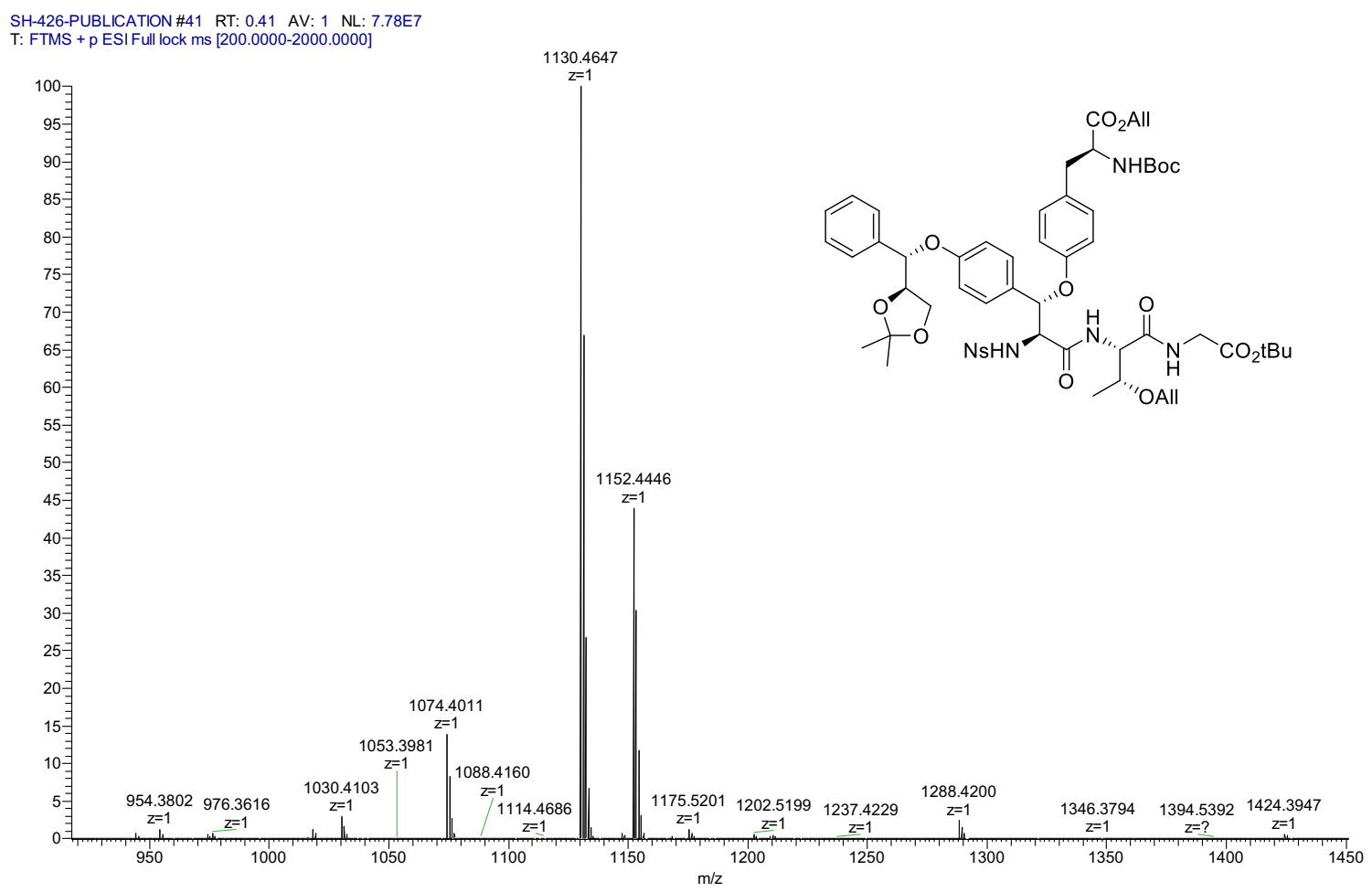


Figures S51-52: ${ }^{1} \mathrm{H}$ and ${ }^{13} \mathrm{C}$ NMR spectra of compound $24\left(500 / 126 \mathrm{MHz}\right.$, acetone- $\left.d_{6}\right)$
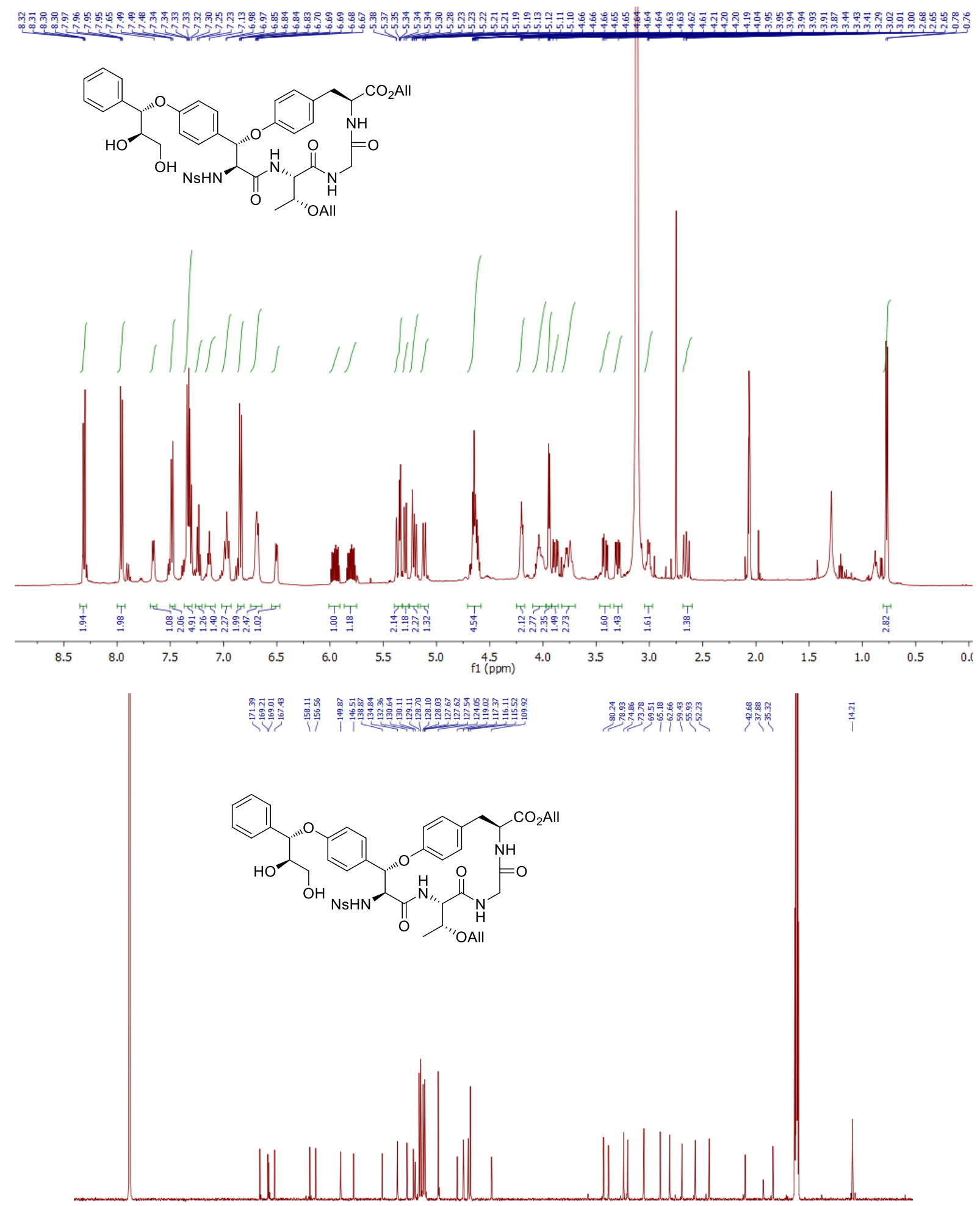

$\begin{array}{llllllllllllllllllllllllll}1 & 210 & 200 & 190 & 180 & 170 & 160 & 150 & 140 & 130 & 120 & 110 & 100 & 90 & 80 & 70 & 60 & 50 & 40 & 30 & 20 & 10 & 0\end{array}$ 
Figure S53: gCOSY spectra of compound 24 (500 MHz, acetone- $\left.d_{6}\right)$

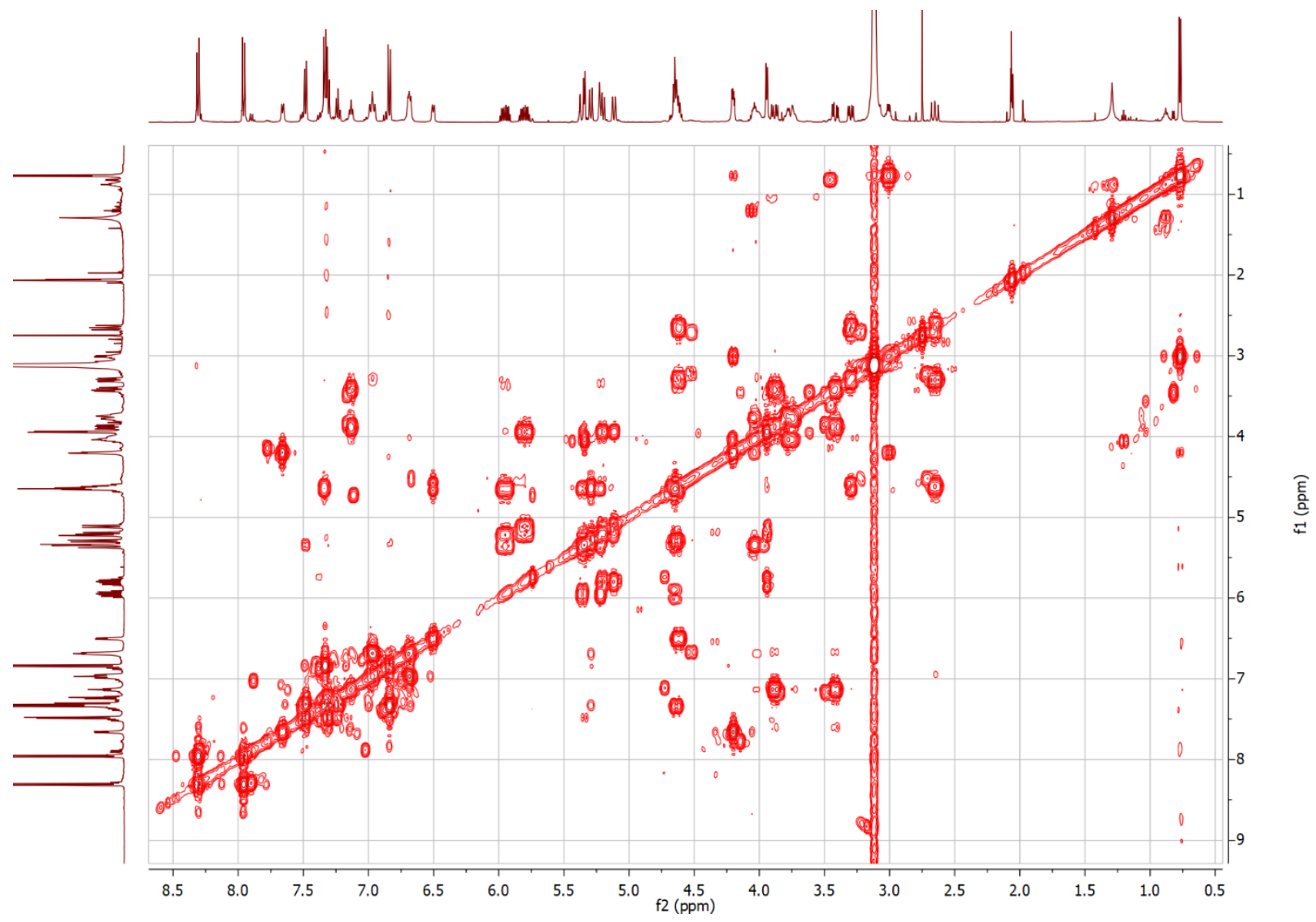

Figure S54: Mass spectrum of 24.

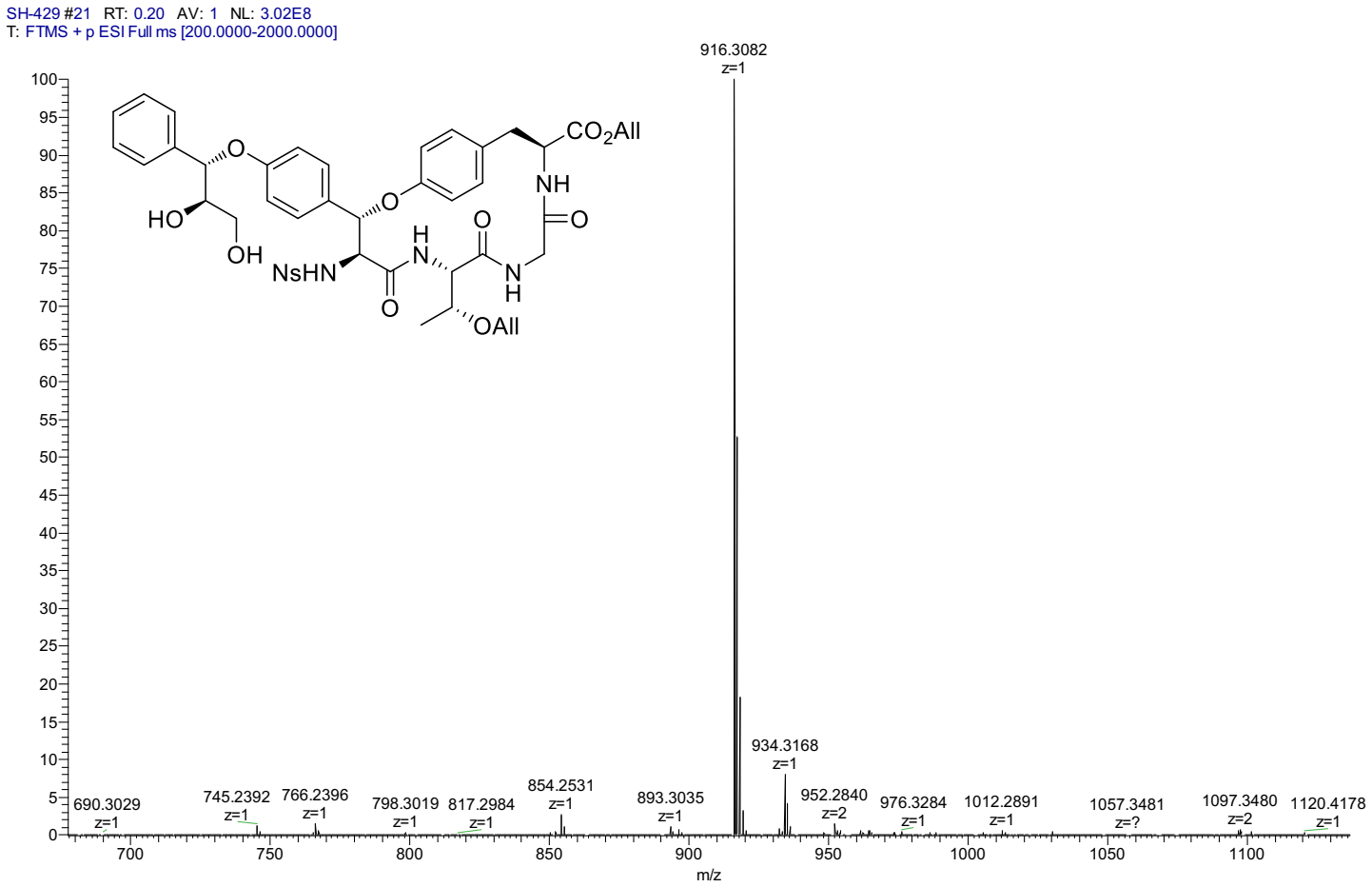


Figures S55-56: ${ }^{1} \mathrm{H}$ and ${ }^{13} \mathrm{C}$ NMR spectra of compound $\mathbf{S 5}\left(500 / 126 \mathrm{MHz}\right.$, acetone- $\left.d_{6}\right)$

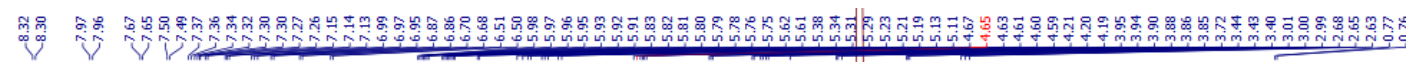<smiles>CC(O)C(NC(=O)CNC(=O)NC(Cc1ccc(OC(C(N)=O)c2ccc(OC(C(=O)O)C(O)c3ccccc3)cc2)cc1)C(N)=O)C(=O)O</smiles>
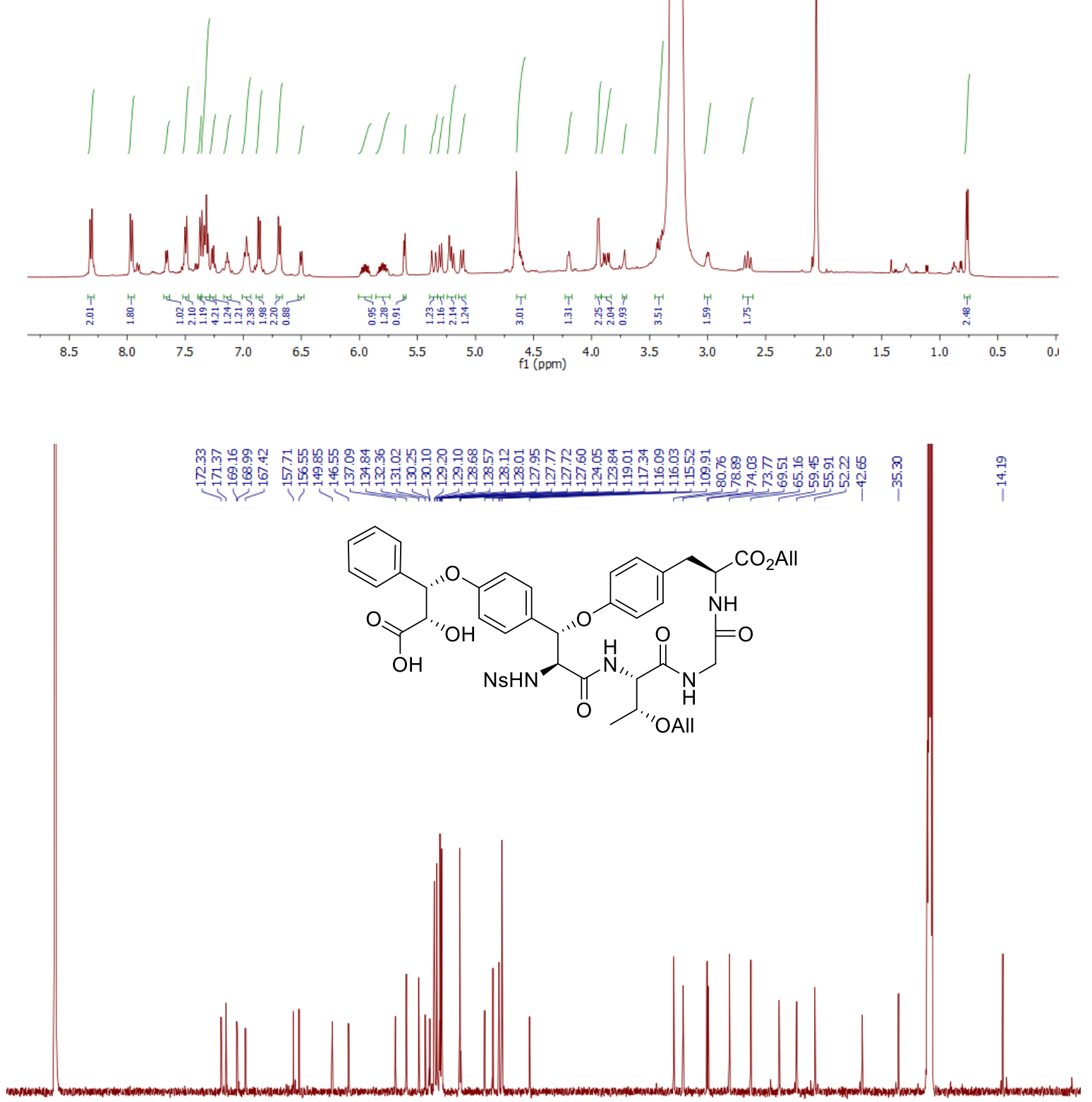

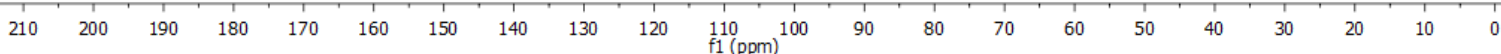


Figure S57: Mass spectrum of S5.

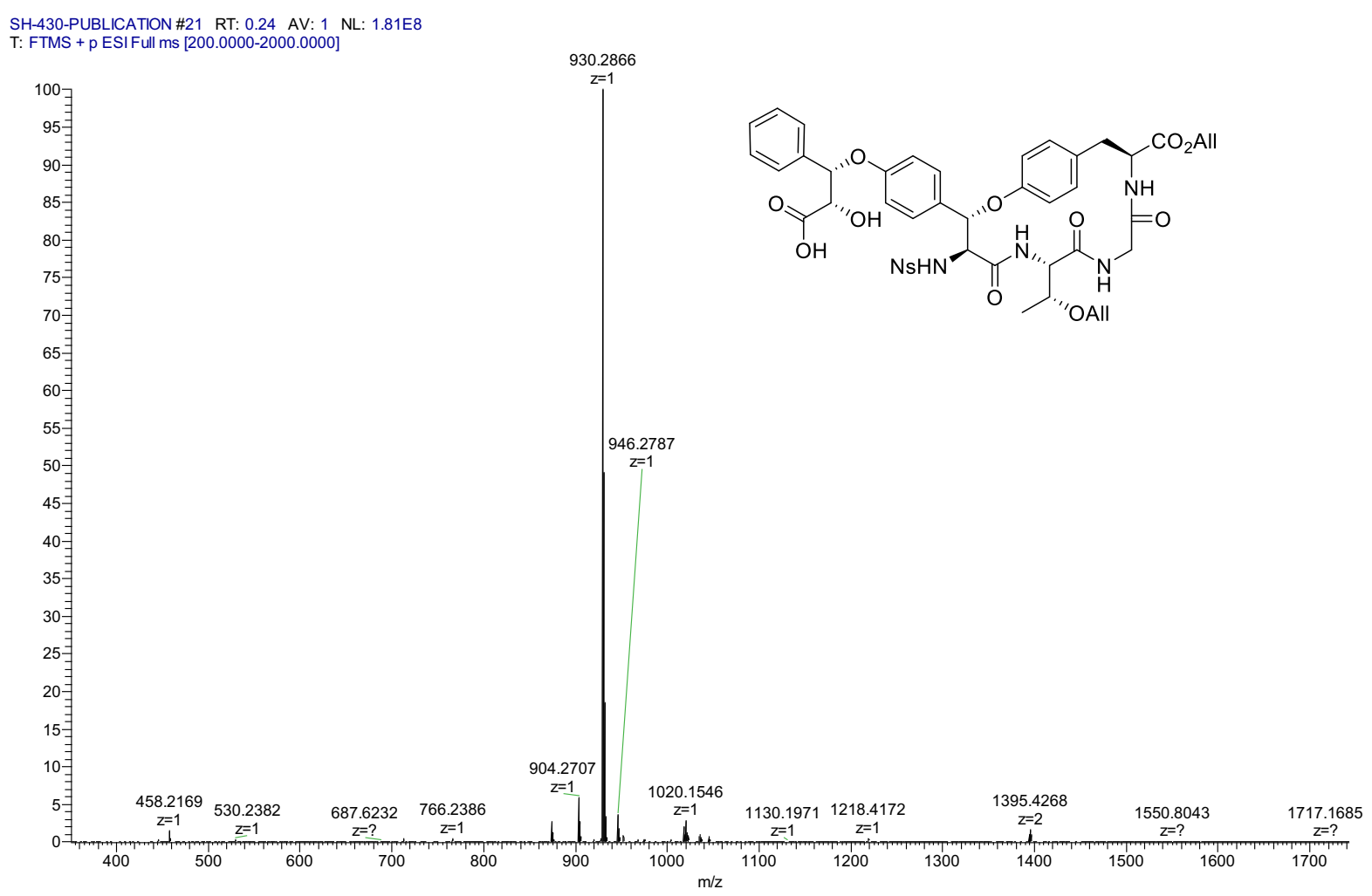


Figures S58-59: ${ }^{1} \mathrm{H}$ and ${ }^{13} \mathrm{C}$ NMR spectra of compound $25\left(600 / 151 \mathrm{MHz}, \mathrm{CD}_{3} \mathrm{OD}\right)$
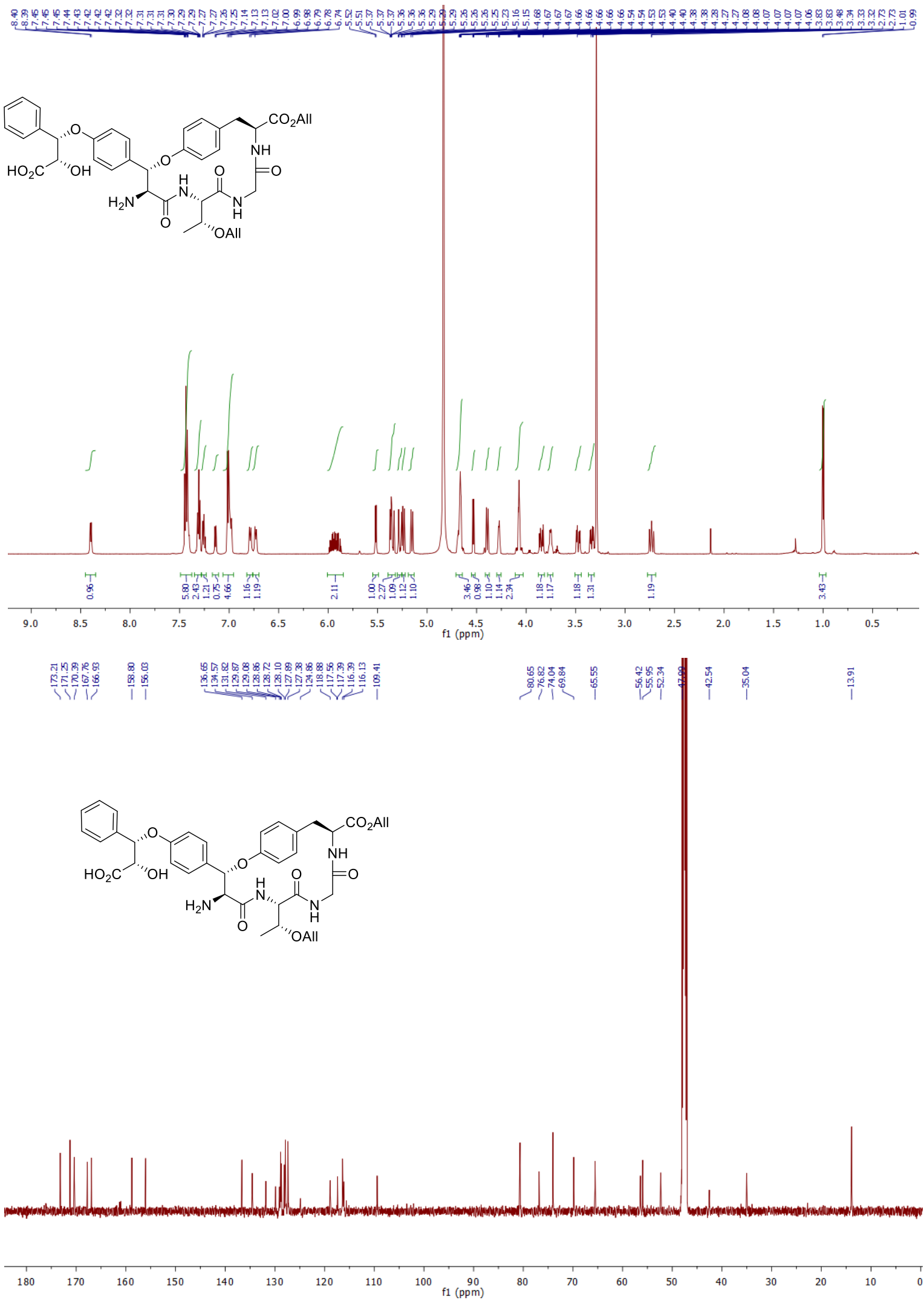
Figure S60: Mass spectrum of $\mathbf{2 5}$.

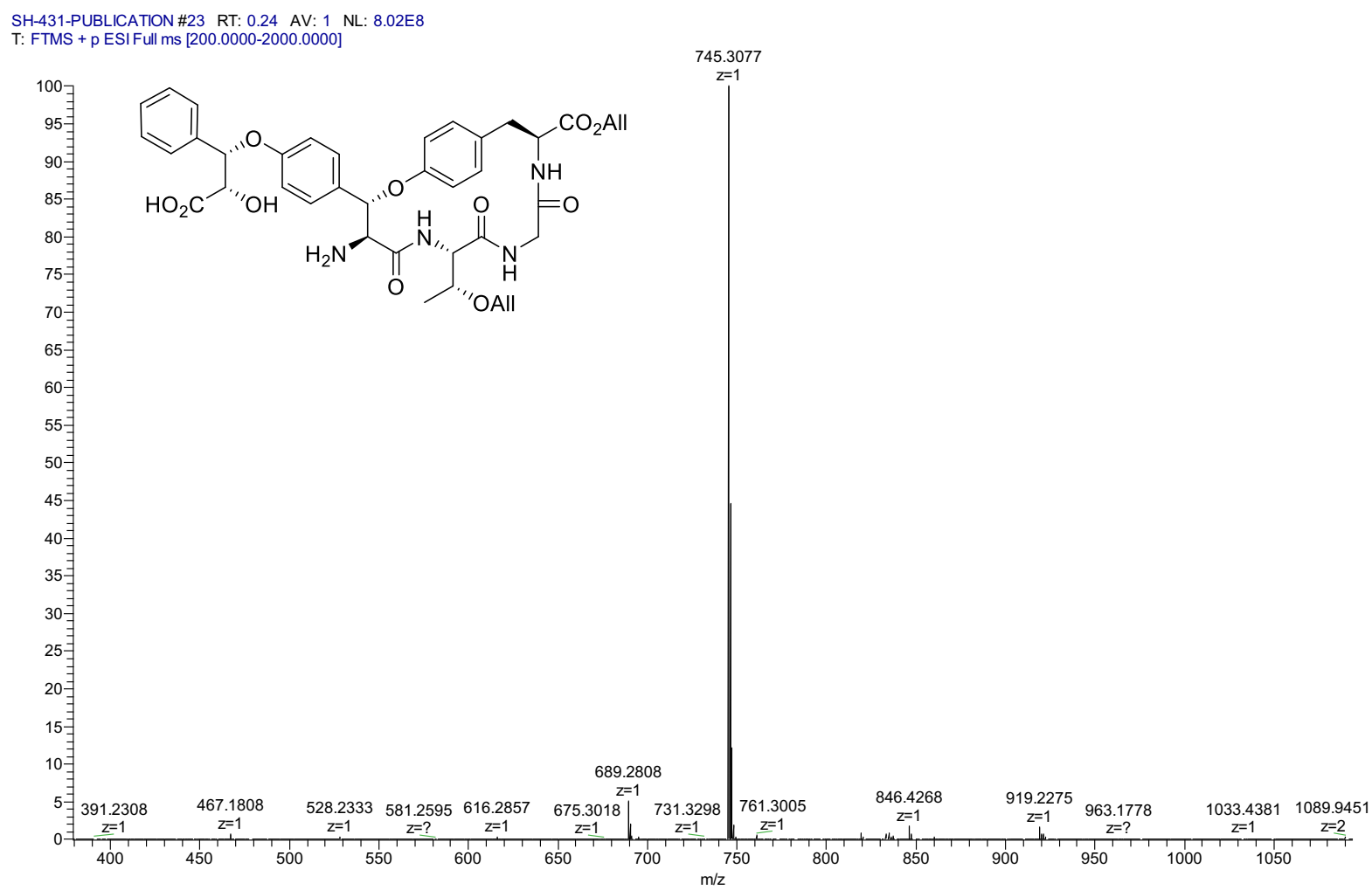


Figures S61-62: ${ }^{1} \mathrm{H}$ and ${ }^{13} \mathrm{C}$ NMR spectra of compound $26\left(500 / 126 \mathrm{MHz}\right.$, acetone- $\left.d_{6}\right)$

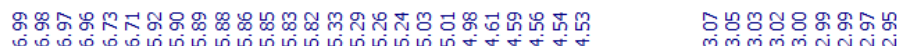

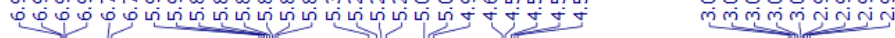<smiles>O=C(OCc1ccccc1)Oc1ccc(CC(C(=O)O)C(=O)O)cc1</smiles>

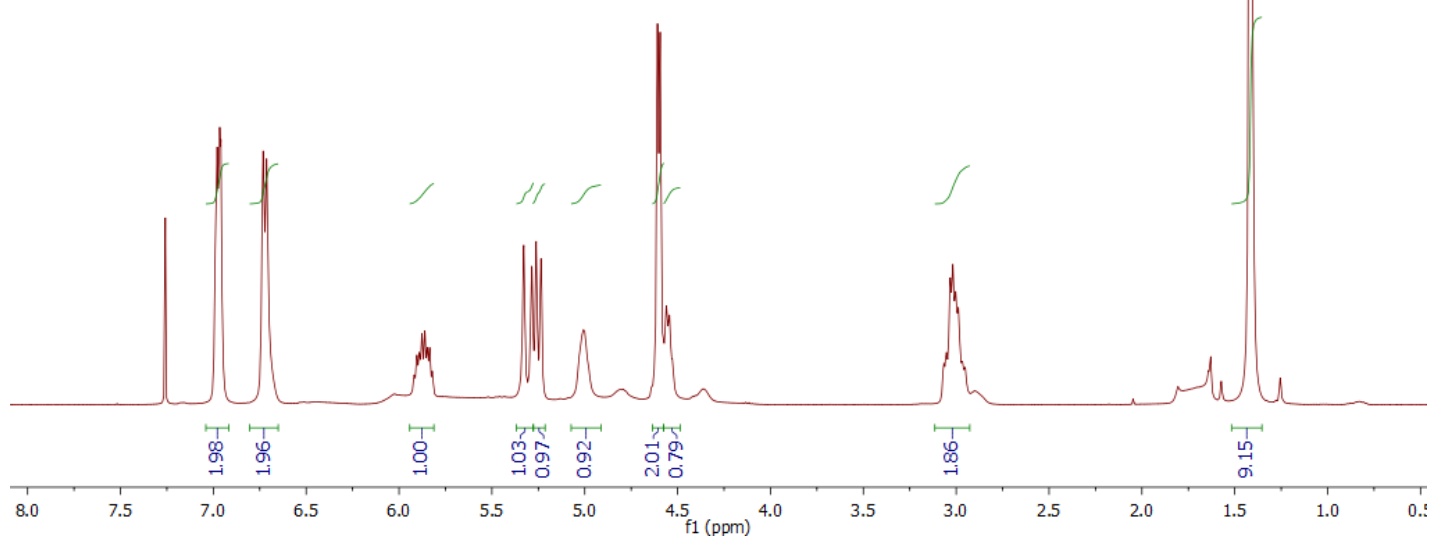

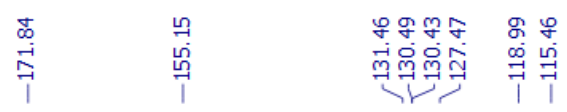

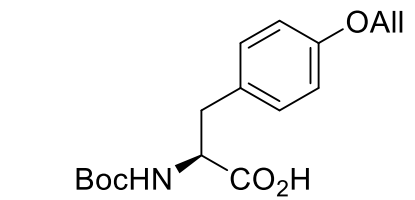


Figures S63-64: ${ }^{1} \mathrm{H}$ and ${ }^{13} \mathrm{C}$ NMR spectra of compound $27\left(500 / 126 \mathrm{MHz}, \mathrm{CD}_{3} \mathrm{OD}\right)$

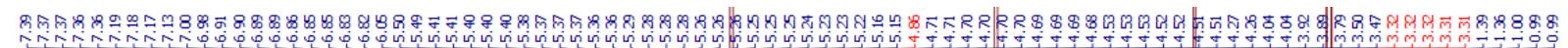

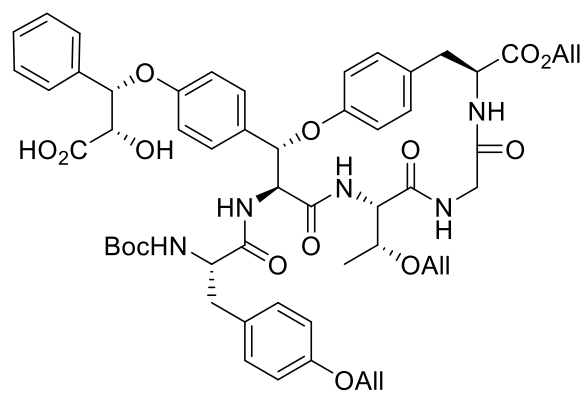
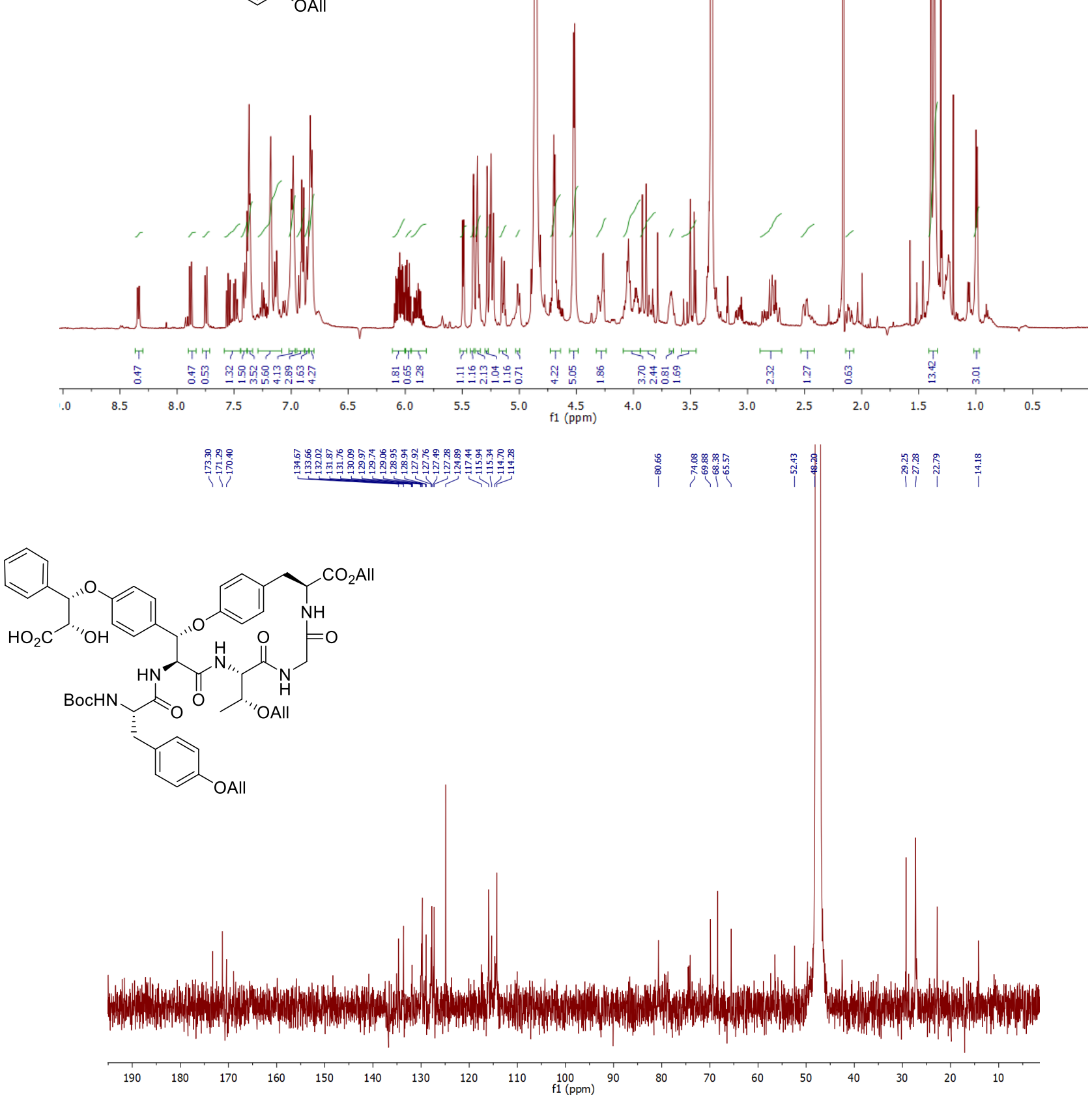
Figure S65: Mass spectrum of 27.

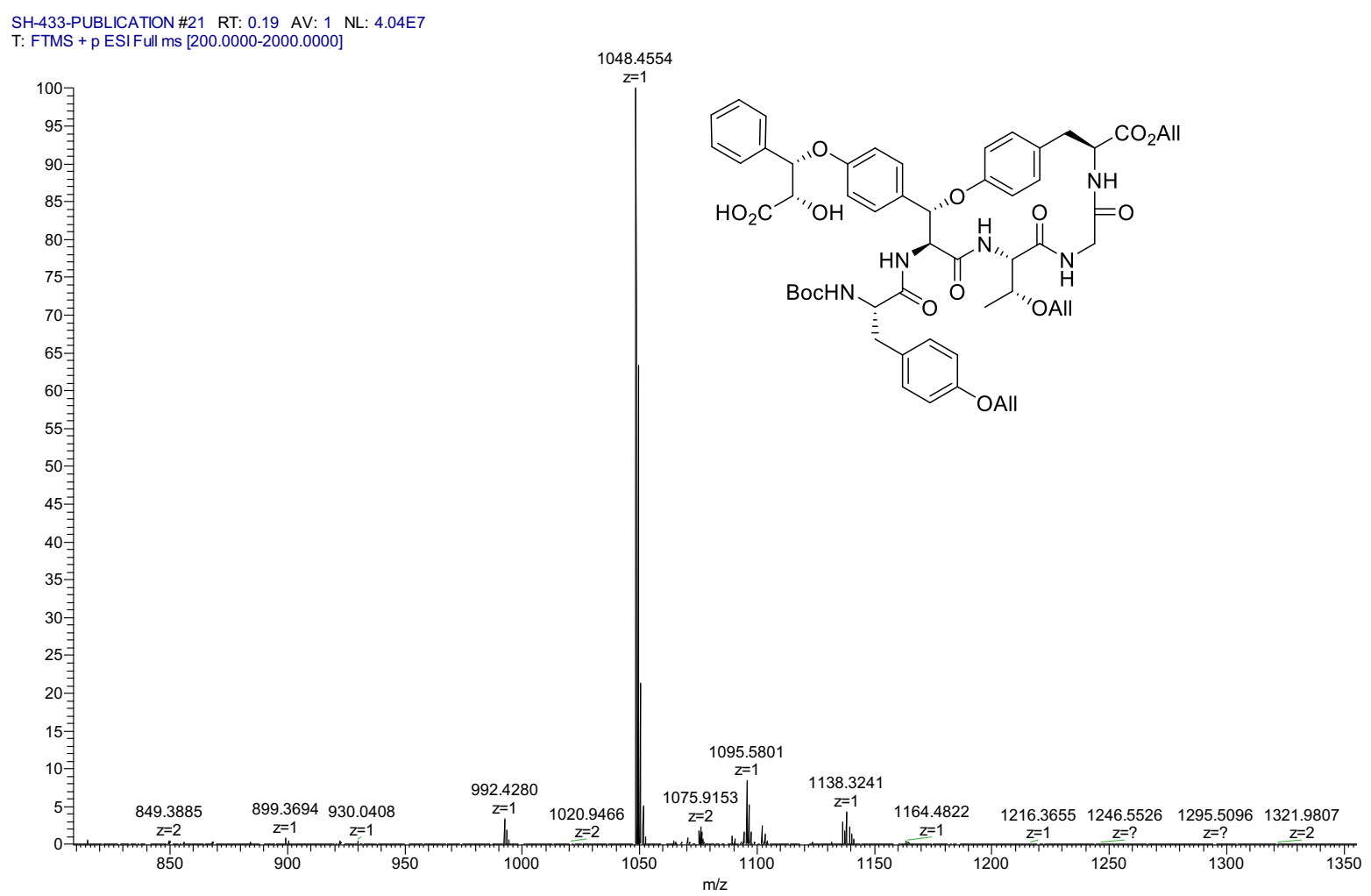


Figures S66-67: ${ }^{1} \mathrm{H}$ NMR spectra of compound $28\left(600 \mathrm{MHz}\right.$, DMSO- $\left.d_{6}\right)$, without and with water suppression

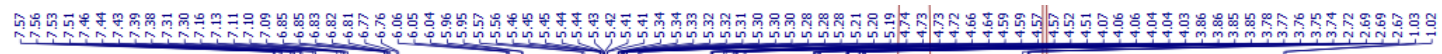
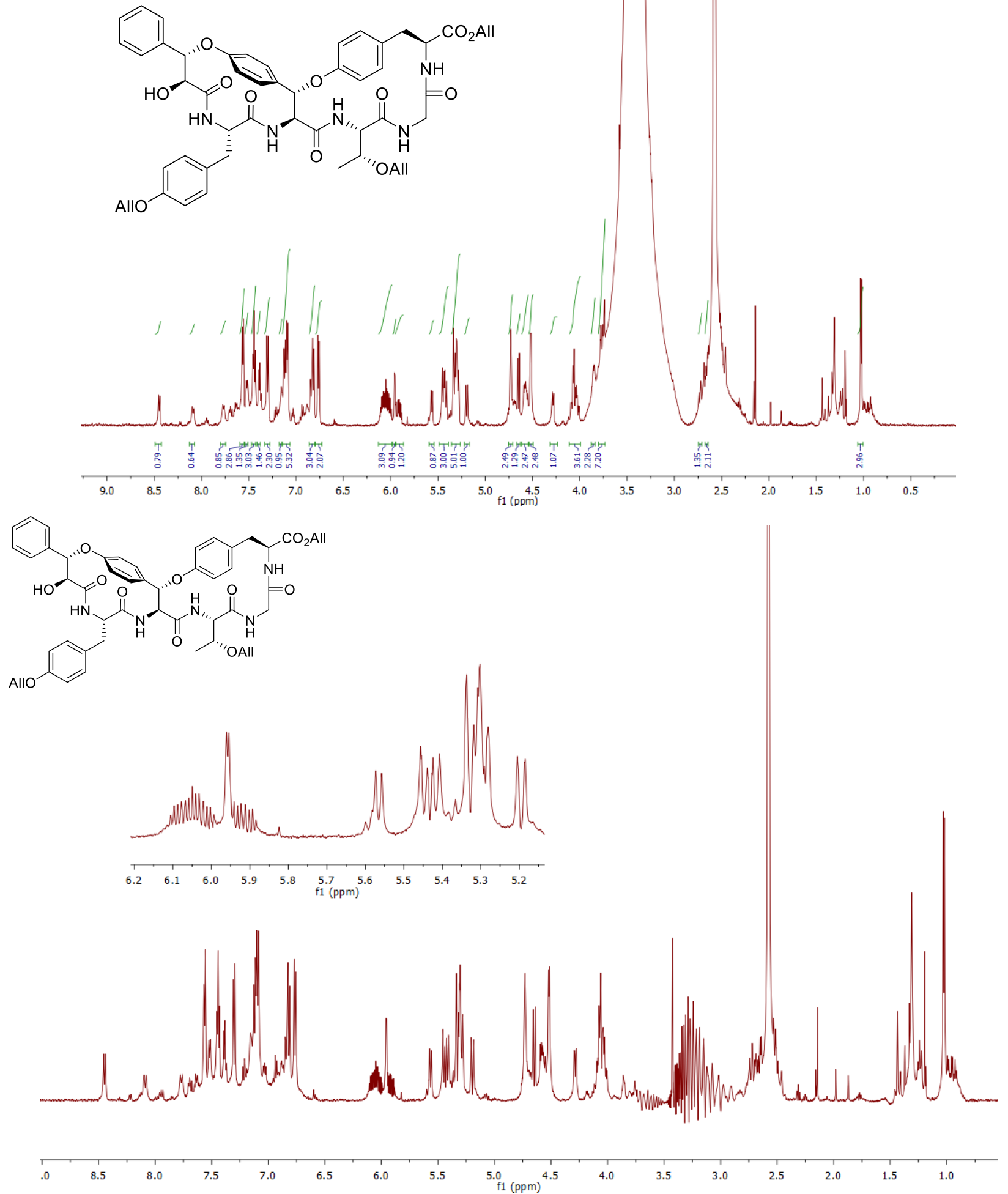
Figure S68: gCOSY spectrum of compound $28\left(600 \mathrm{MHz}, \mathrm{DMSO}-d_{6}\right)$

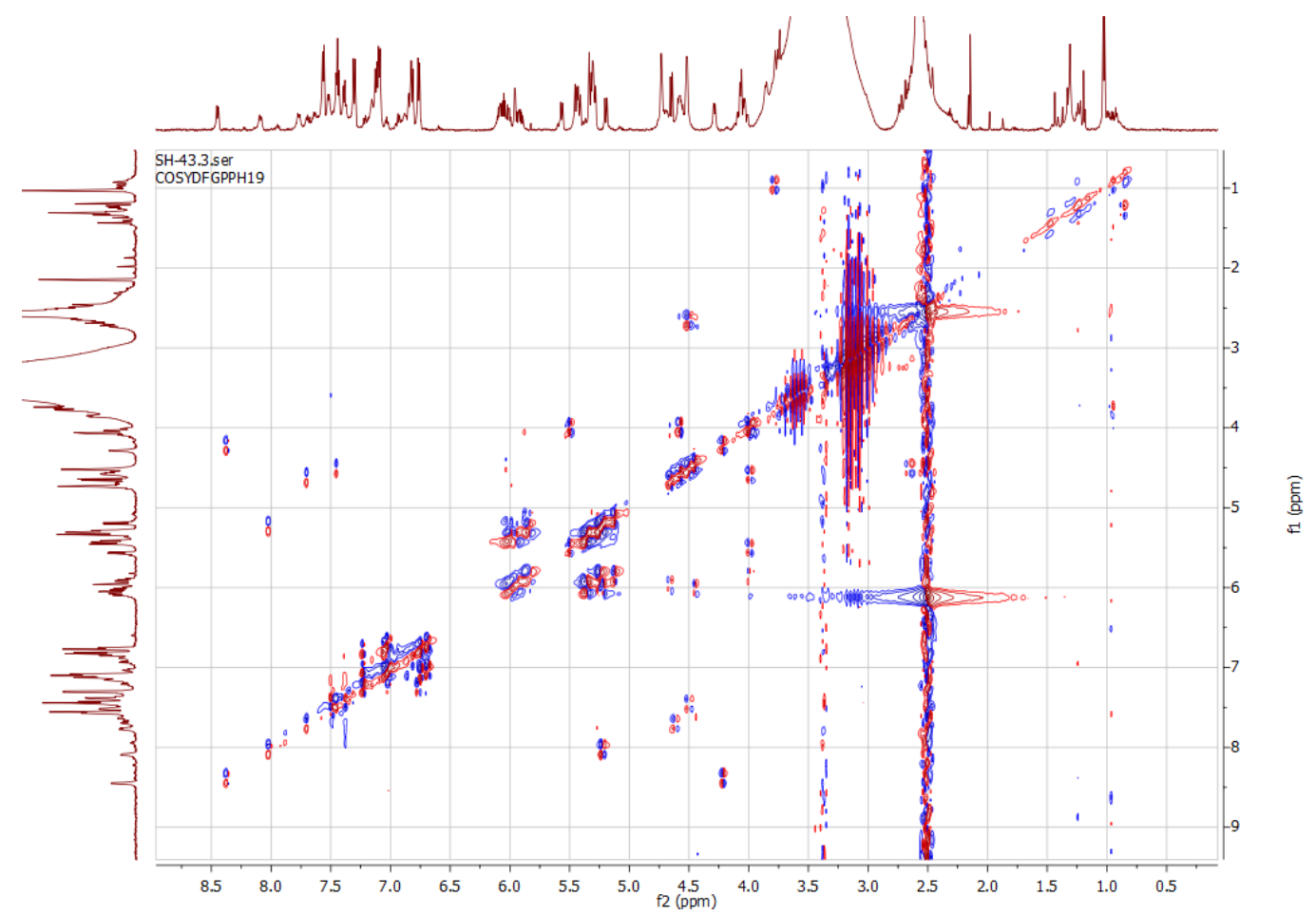

Figure S69: Mass spectrum of 28.

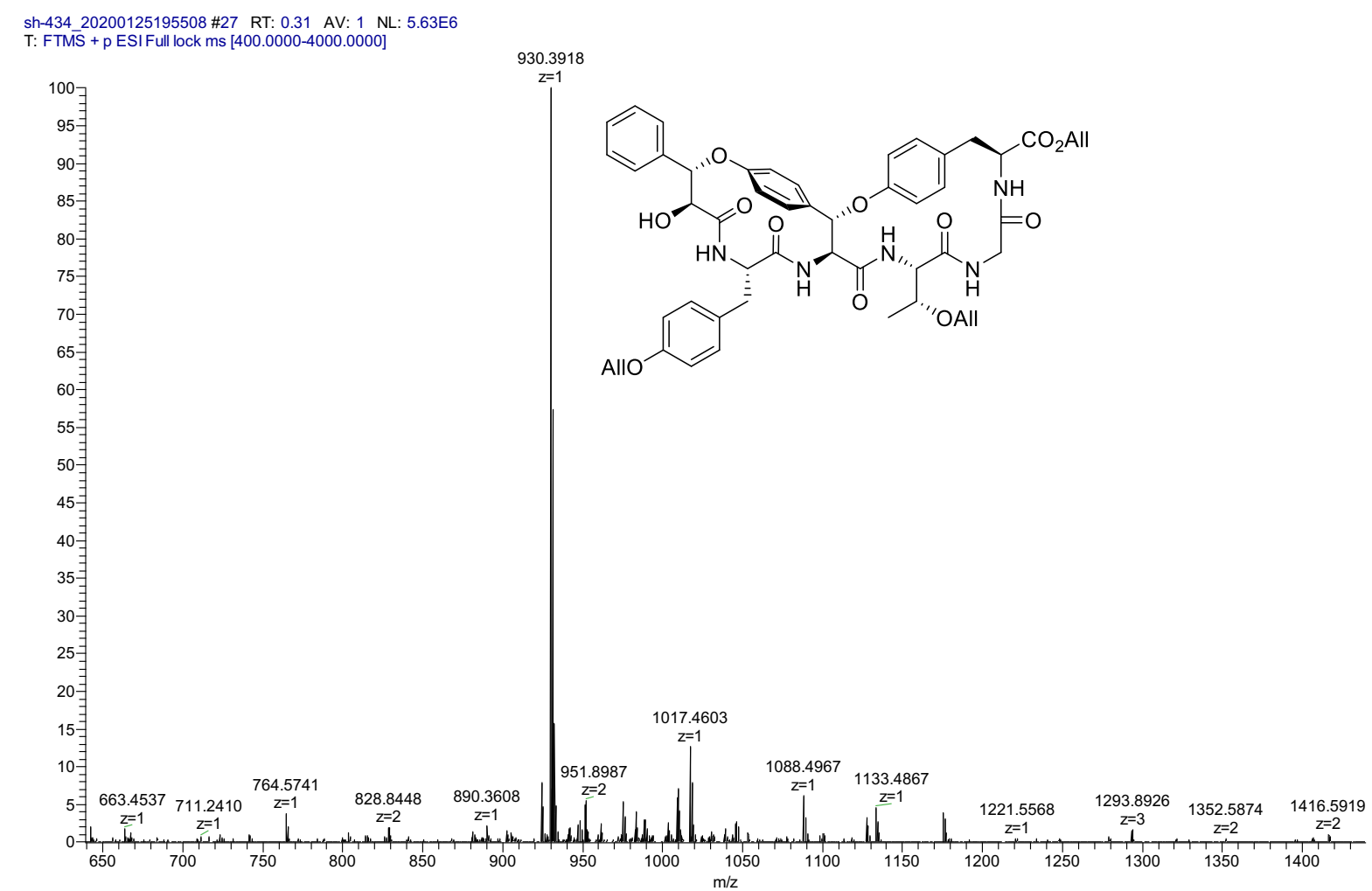


Figure S70: ${ }^{1} \mathrm{H}$ NMR spectrum of compound $29\left(600 \mathrm{MHz}\right.$, DMSO- $\left.d_{6}\right)$

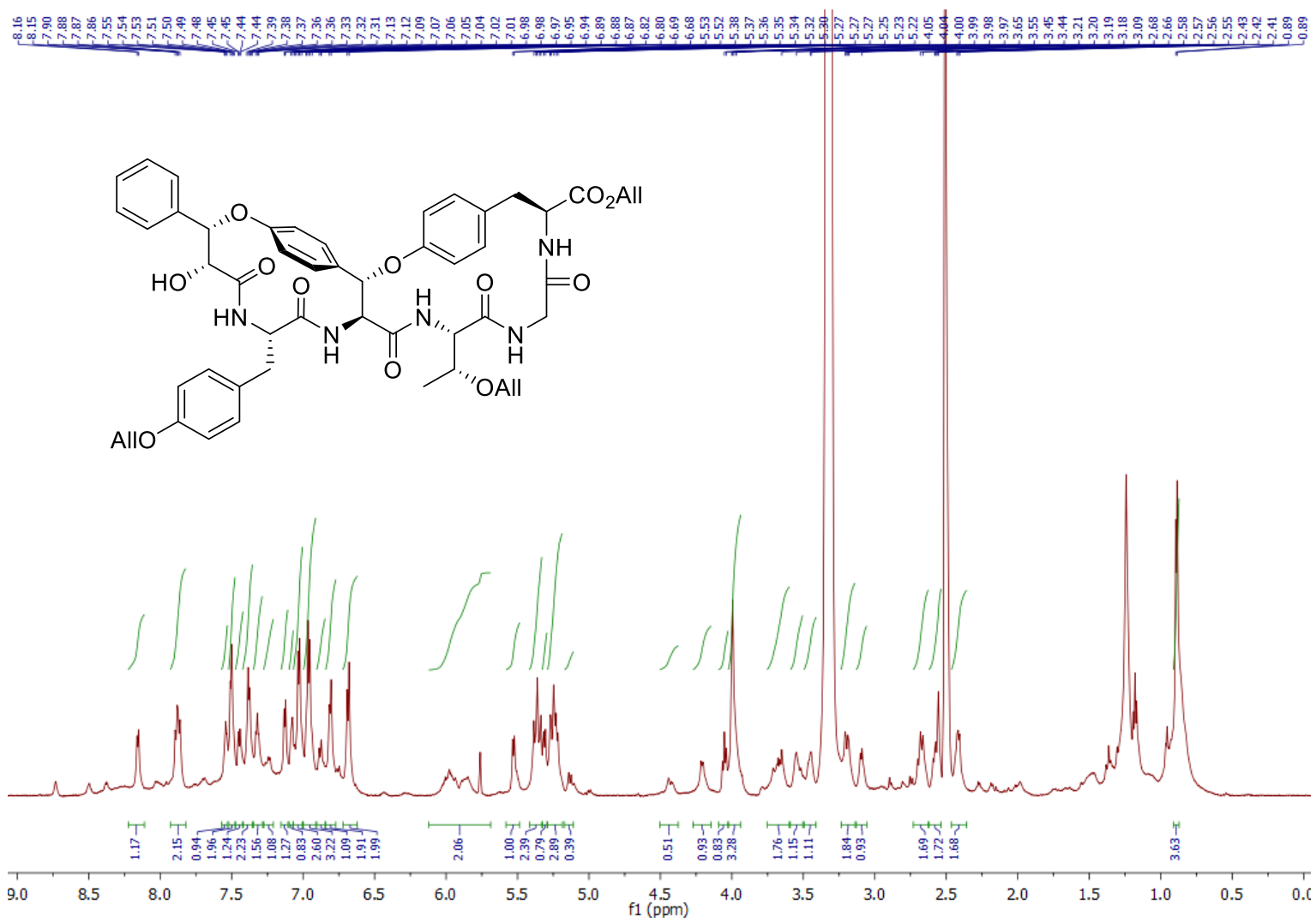

Figure S71: Mass spectrum of 29.

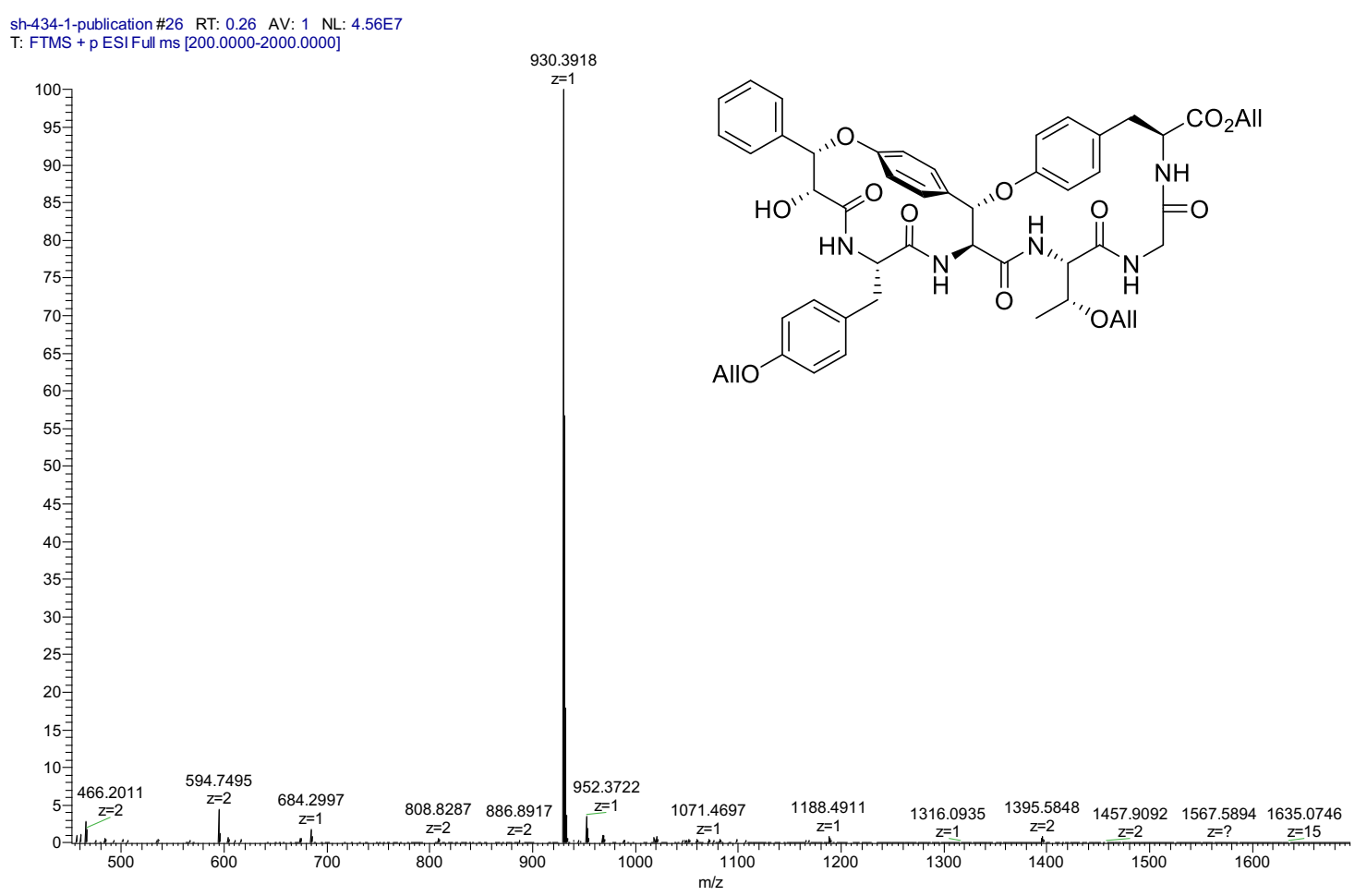


Figure S72: ${ }^{1} \mathrm{H}$ NMR spectrum of epi-asperipin-2a $1\left(600 \mathrm{MHz}, \mathrm{DMSO}-d_{6}\right)$

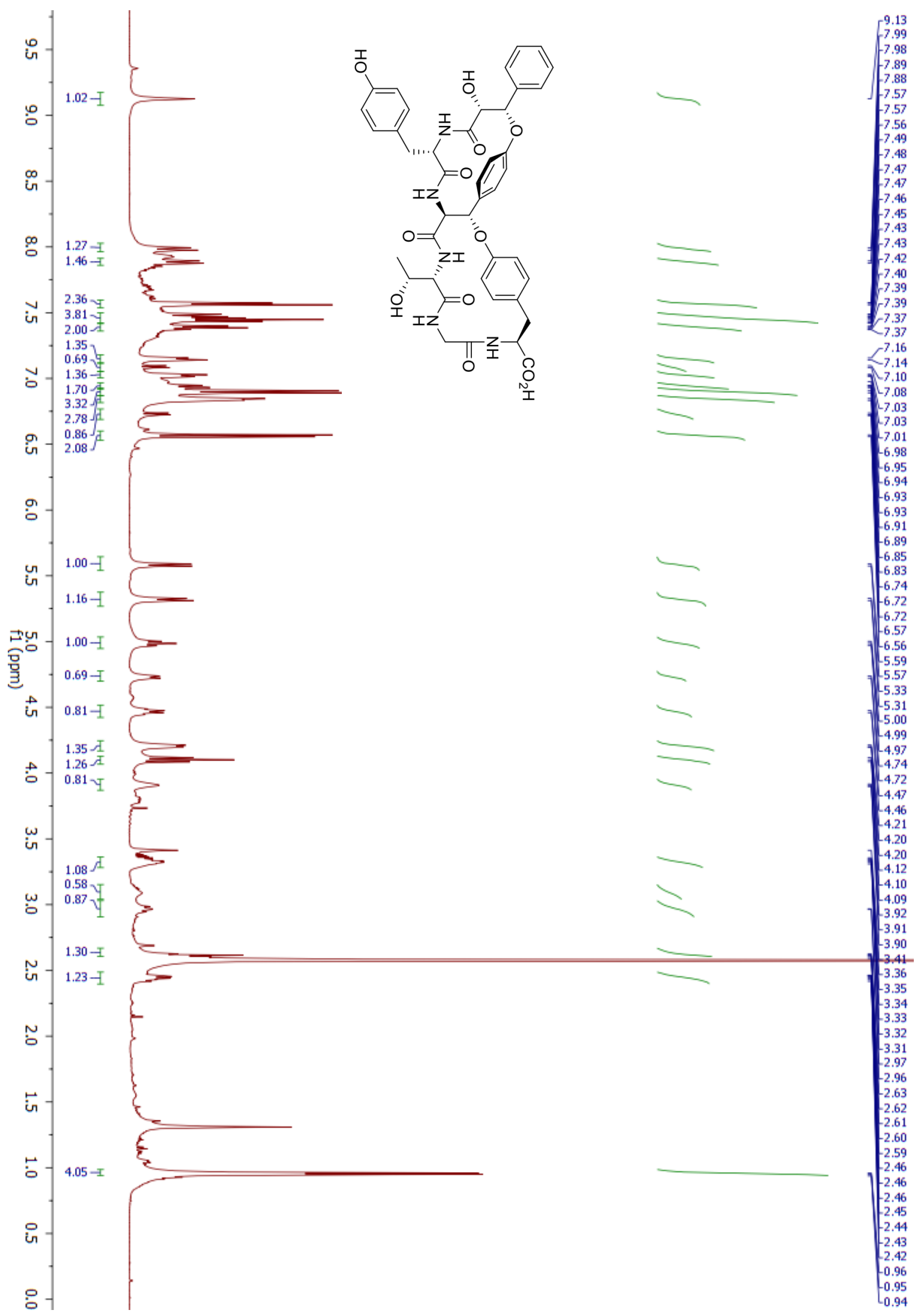


Figure S73: gCOSY spectrum of epi-asperipin-2a 1 (600 MHz, DMSO- $\left.d_{6}\right)$

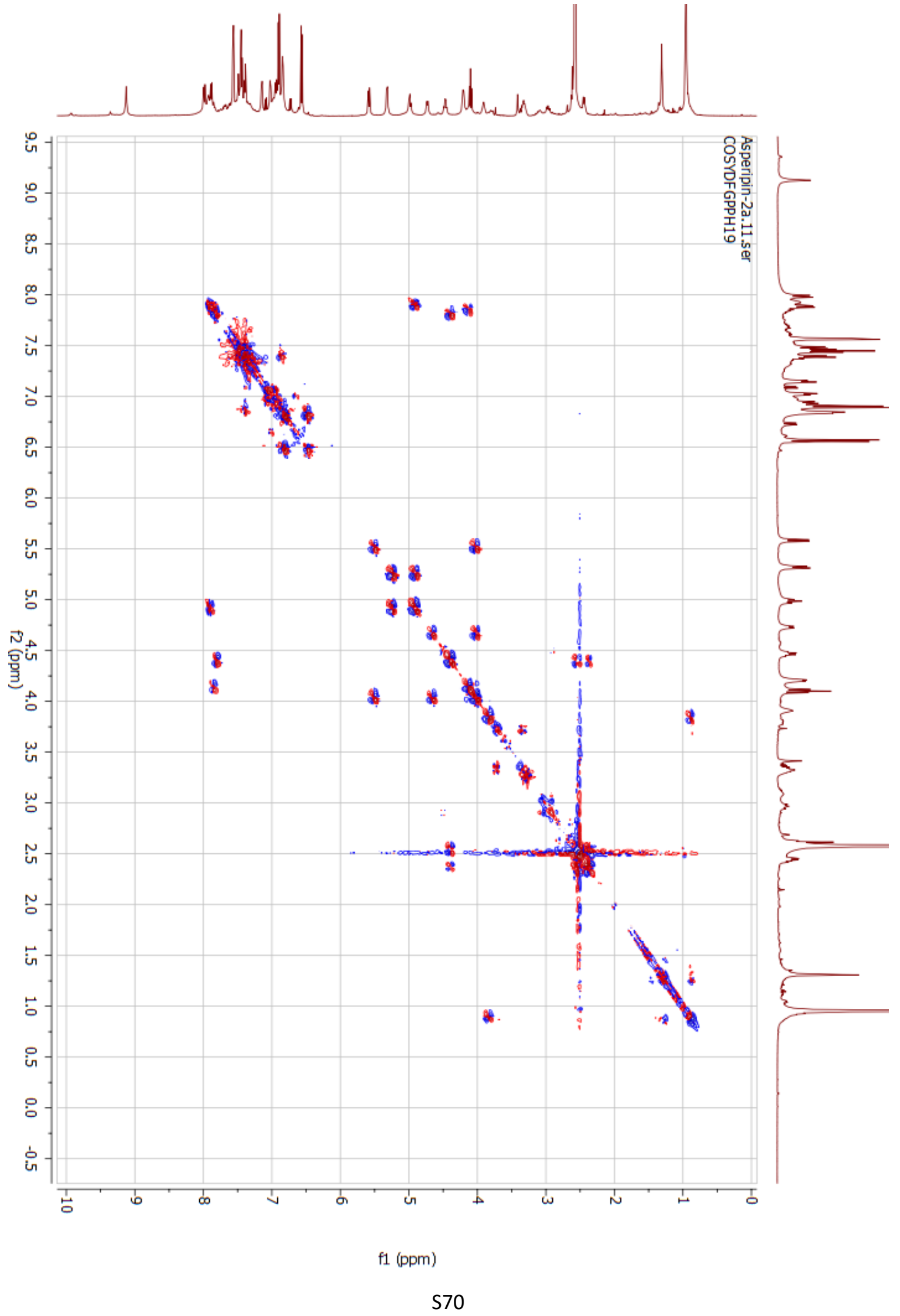


Figure S74: ${ }^{13} \mathrm{C}$ NMR spectrum of epi-asperipin-2a 1 (126 MHz, DMSO- $\left.d_{6}\right)$

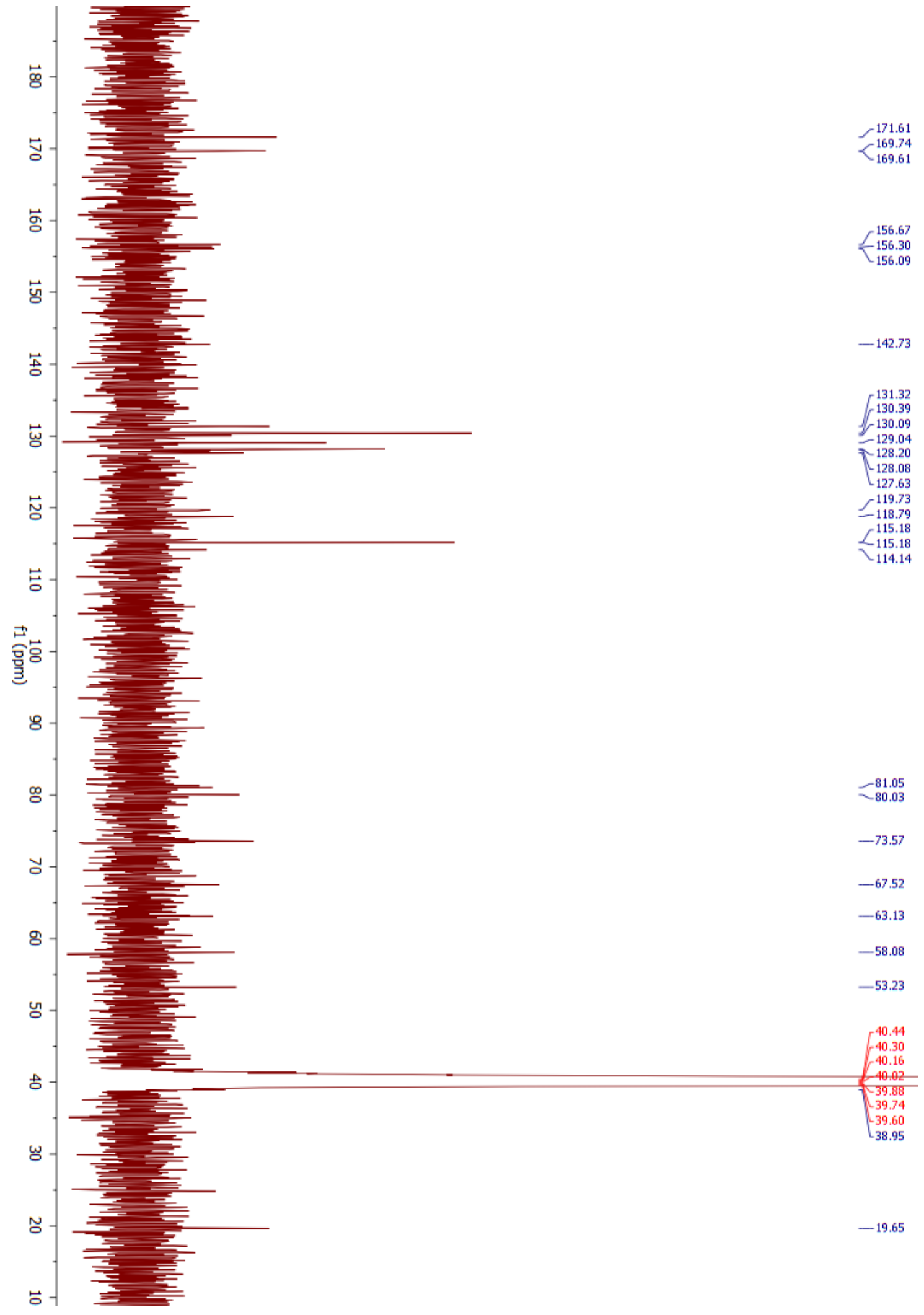


Figure S75: HSQC spectrum of epi-asperipin-2a 1 (600 MHz, DMSO- $\left.d_{6}\right)$

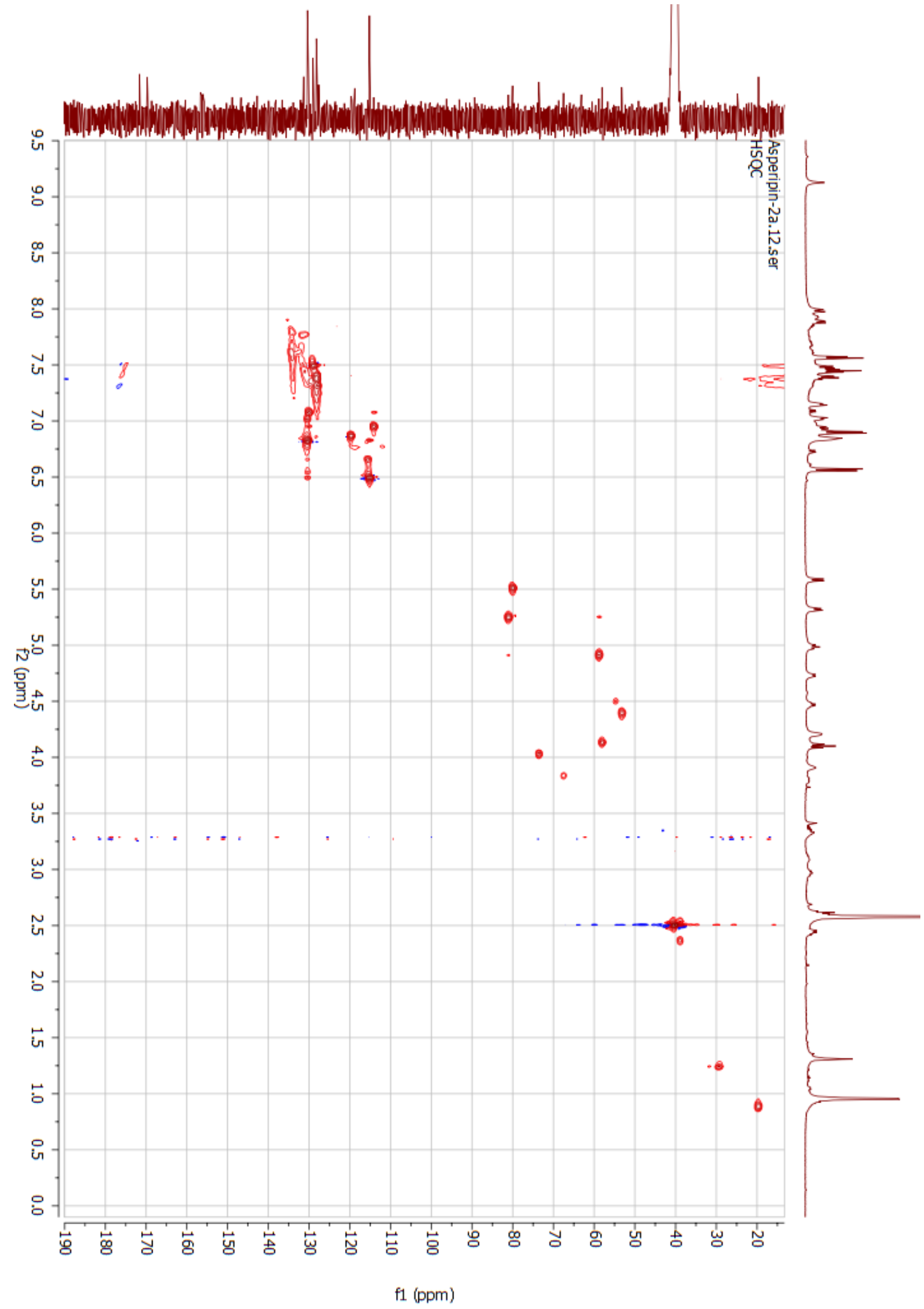


Figures S76-77: ${ }^{1} \mathrm{H}$ NMR and gCOSY spectra of natural asperipin-2a (600 MHz, DMSO- $\left.d_{6}\right)$

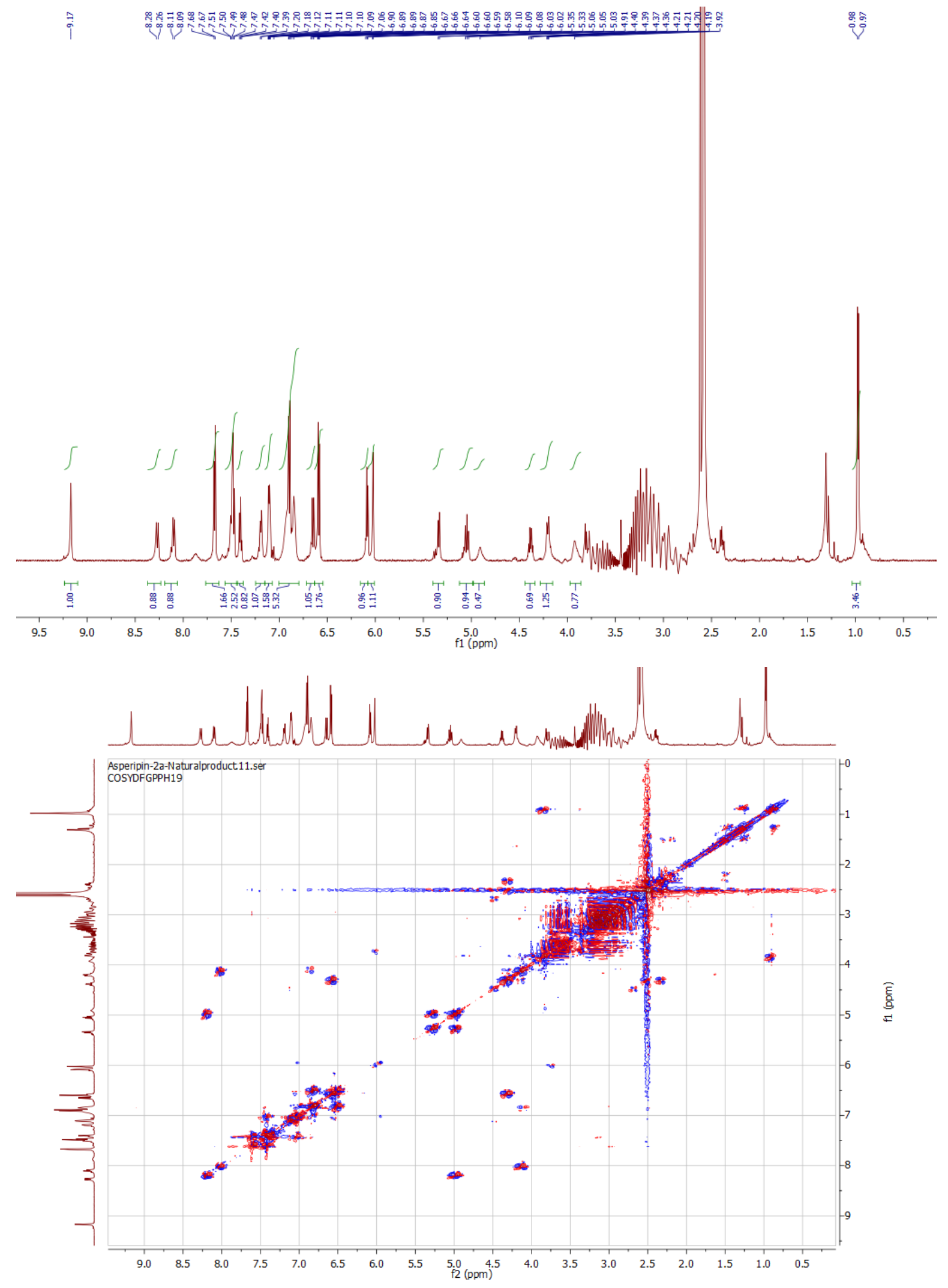


Figure S78: HSQC spectrum of natural asperipin-2a (600 MHz, DMSO- $\left.d_{6}\right)$

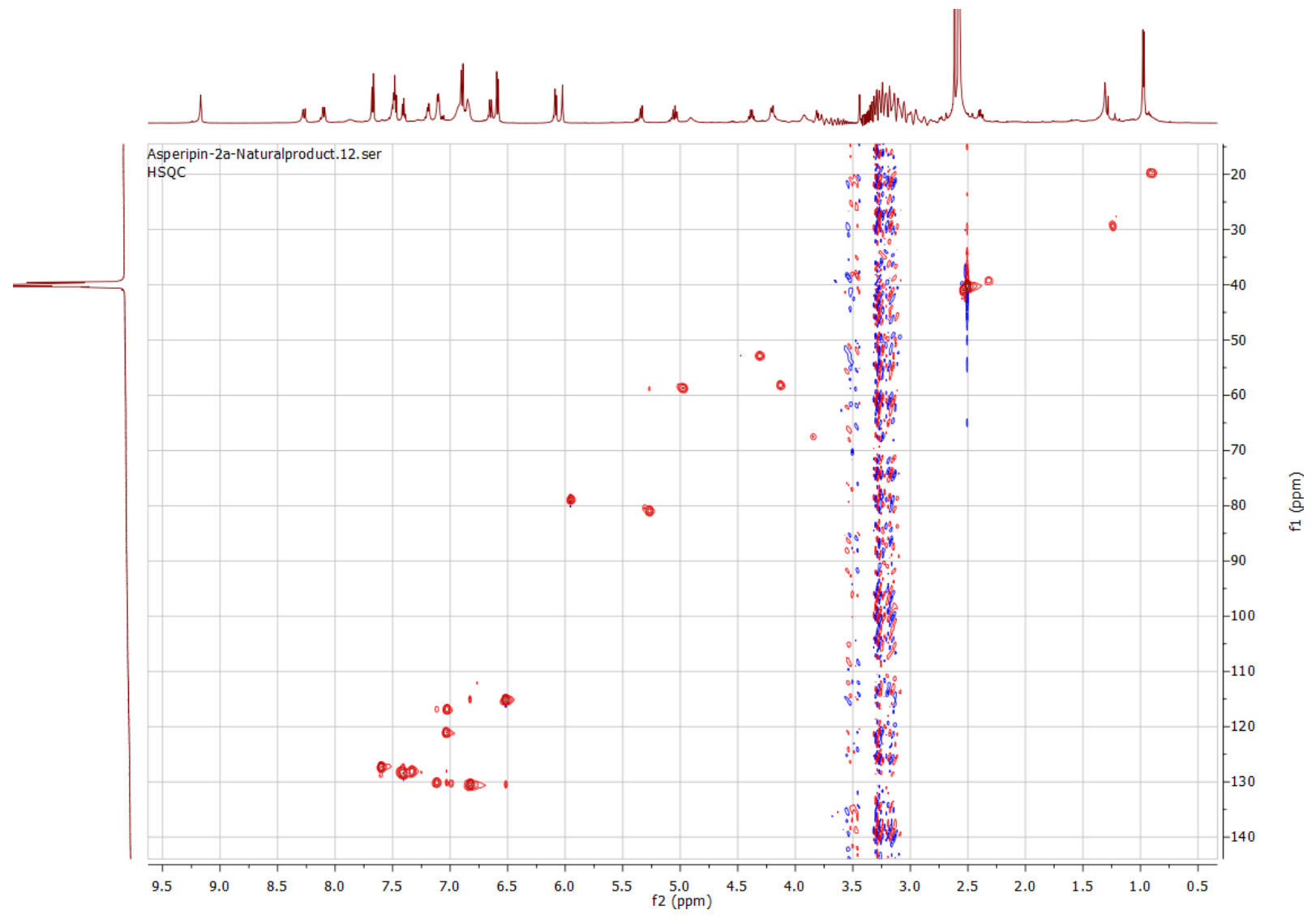


Figure S79: Mass spectrum of synthetic epi-asperipin-2a 1

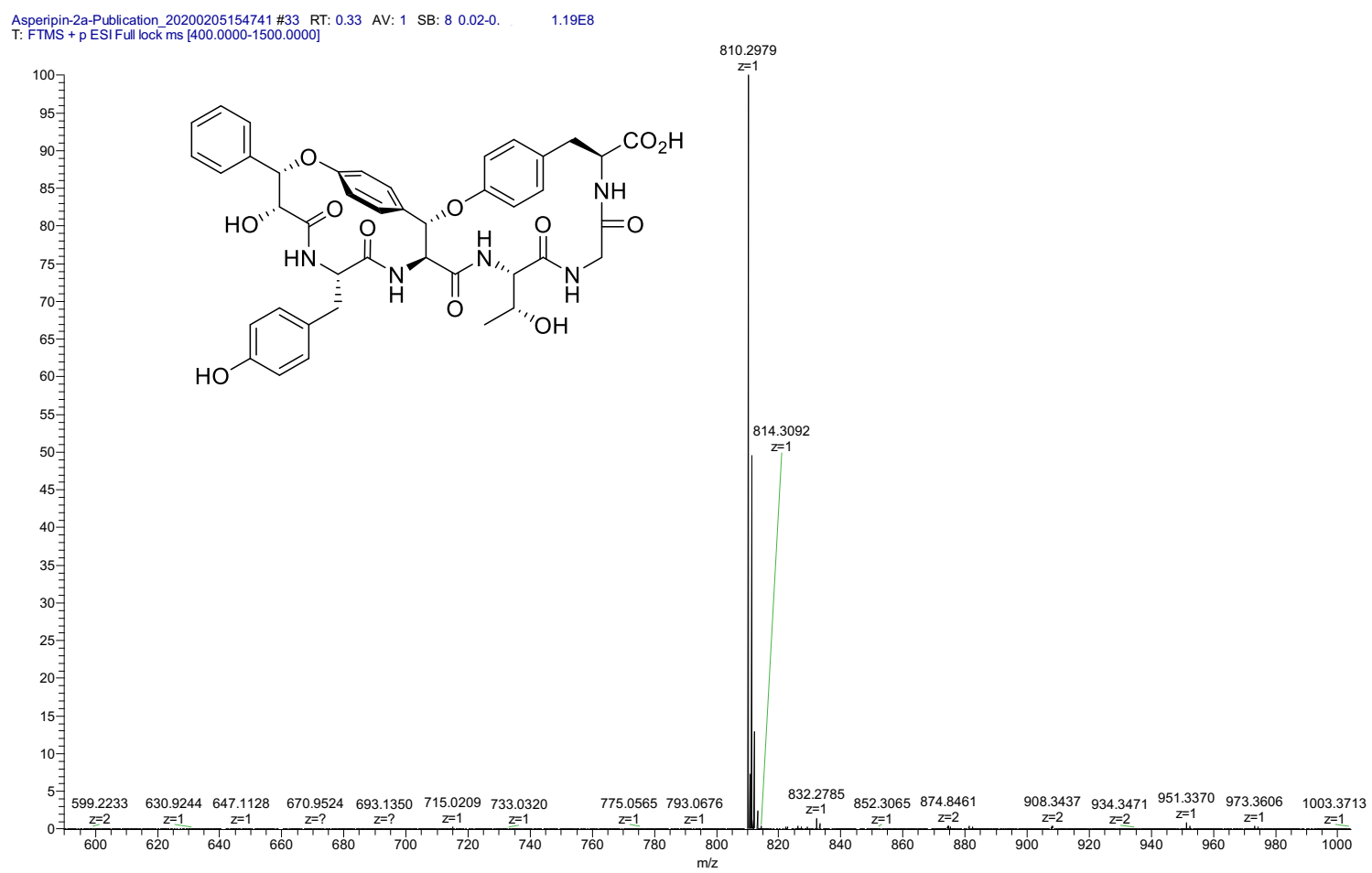

Figure S80: Mass spectrum of natural asperipin-2a

Asperipin-2a-AuthenticSample \#24 RT: $0.23 \quad$ AV: 1 SB: 8 0.03-0.10 NL: $1.32 E 7$ T: FTMS + p ESI Full lock ms [100.0000-1000.0000]

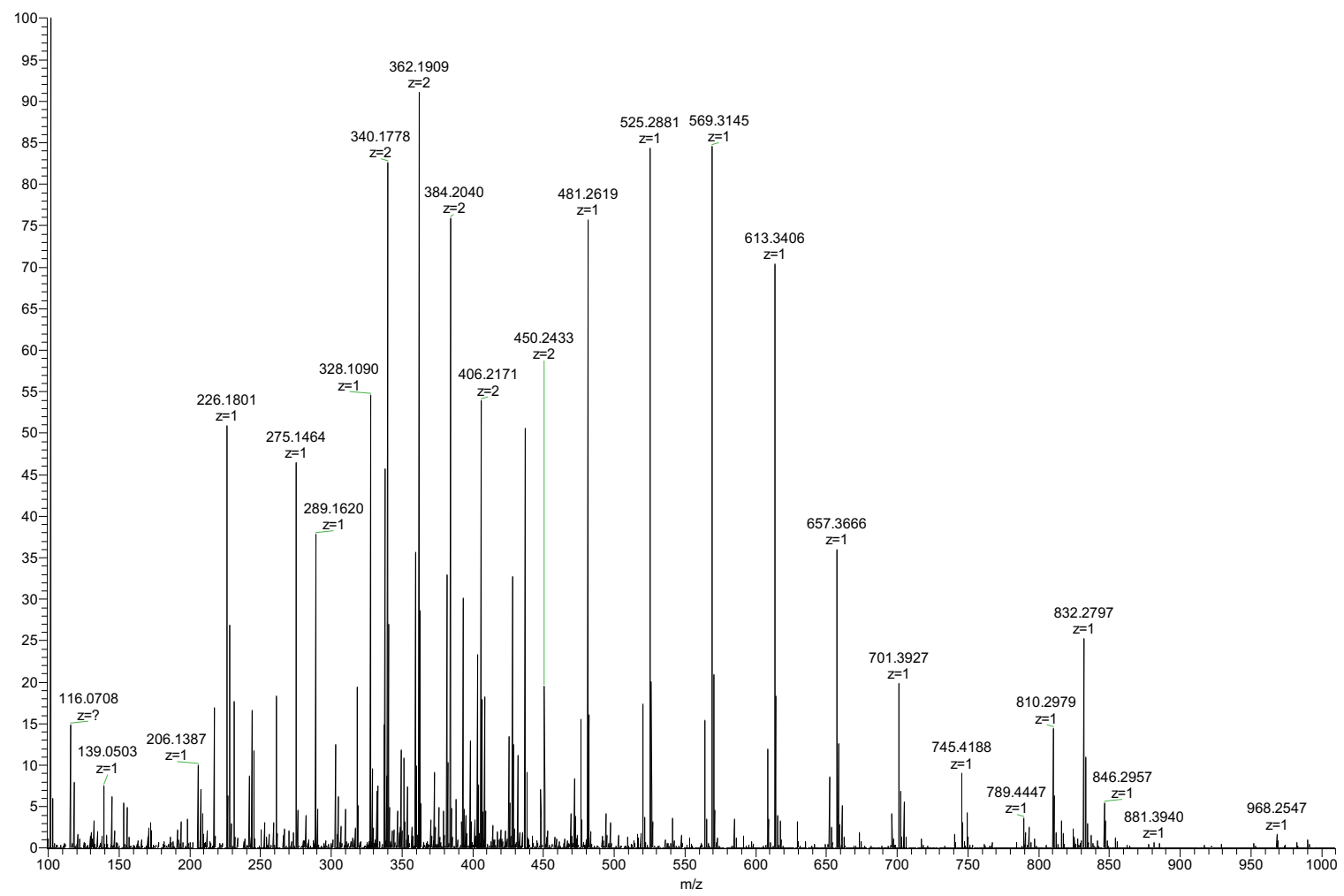


Figures S81-91: ${ }^{1} \mathrm{H}$ NMR spectra expansions for comparison of $\mathrm{H} 2$ and $\mathrm{H} 16$ protons in various diastereomers of asperipin-2a and precursors:

Figure S81: Mixture of diastereomers 14 (minor isomer confirmed by X-ray structure)

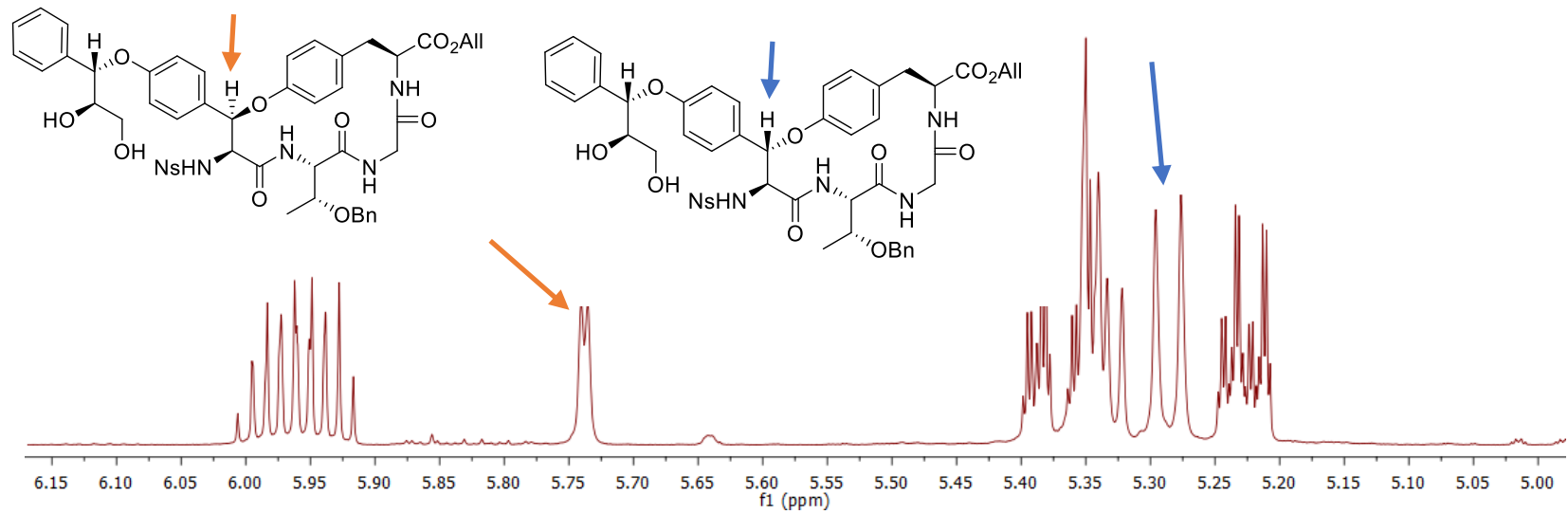

Figure S82: Mixture of diastereomers of 17

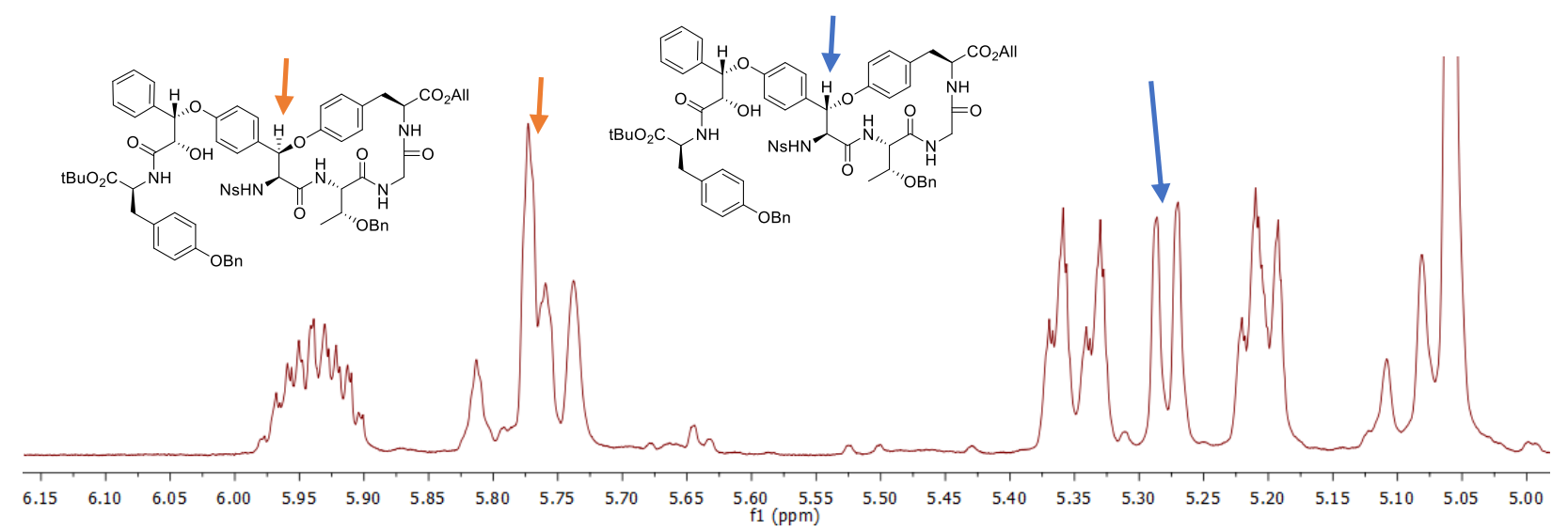

Figure S83: Mixture of diastereomers of 24

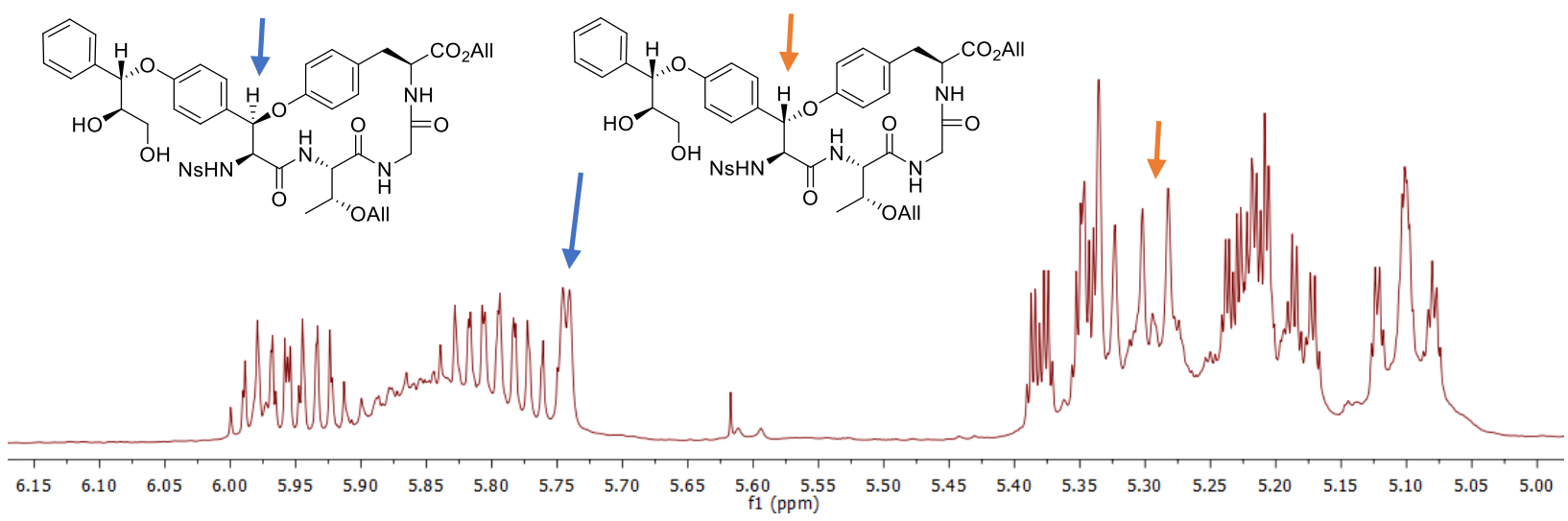


Figure S84: ${ }^{1} \mathrm{H}$ NMR of major isomer 24a

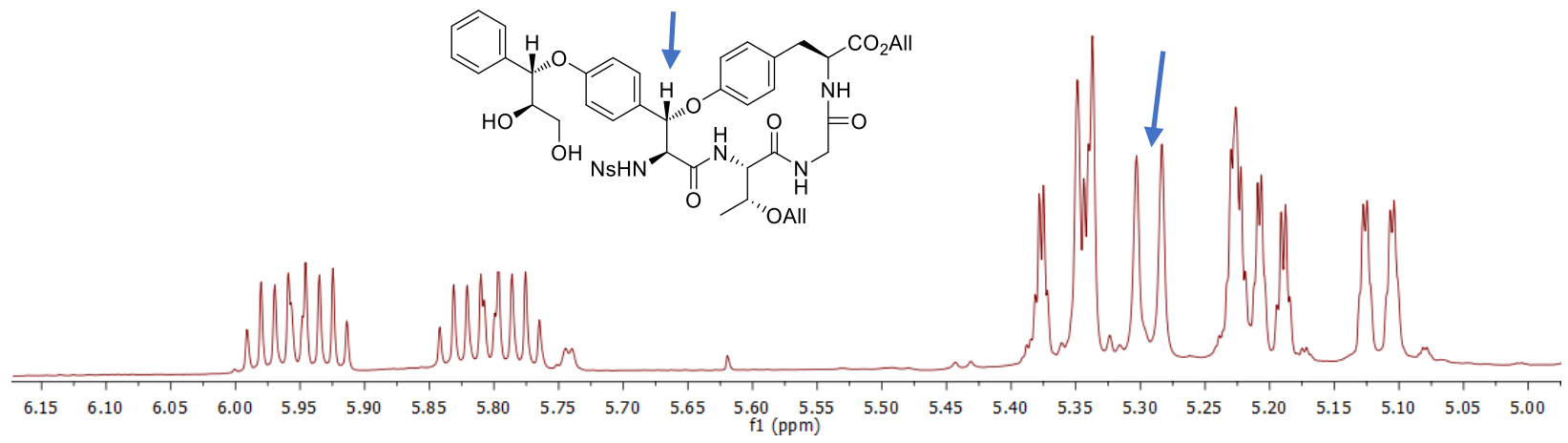

Figure S85: ${ }^{1} \mathrm{H}$ NMR of S5

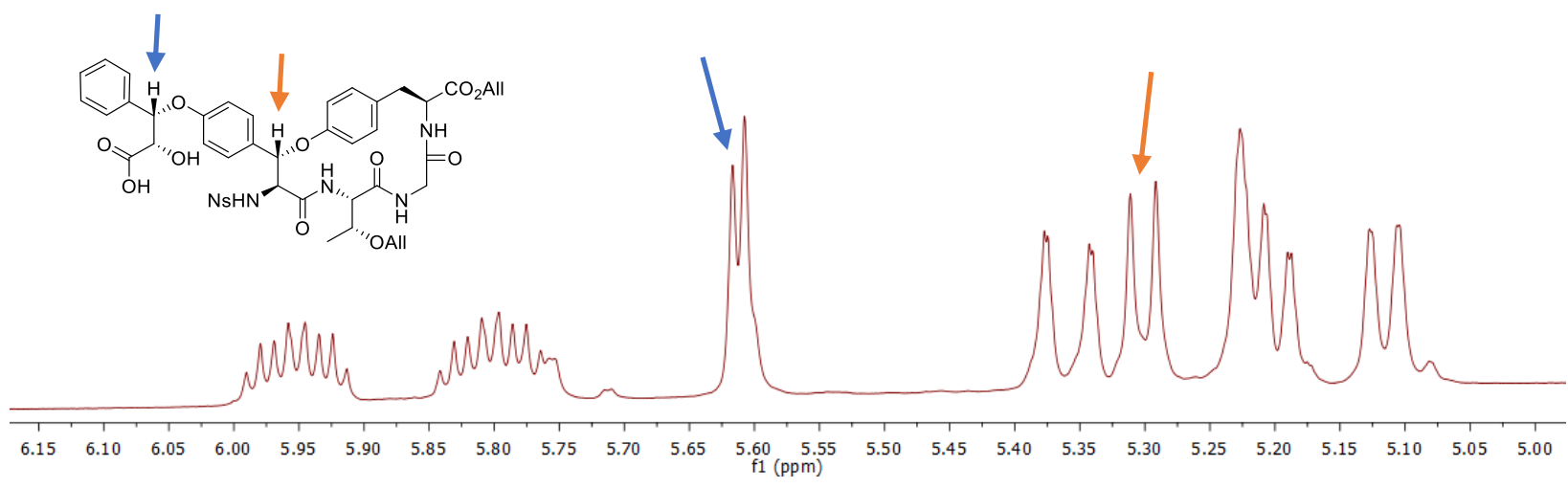

Figure S86: ${ }^{1} \mathrm{H}$ NMR of 25

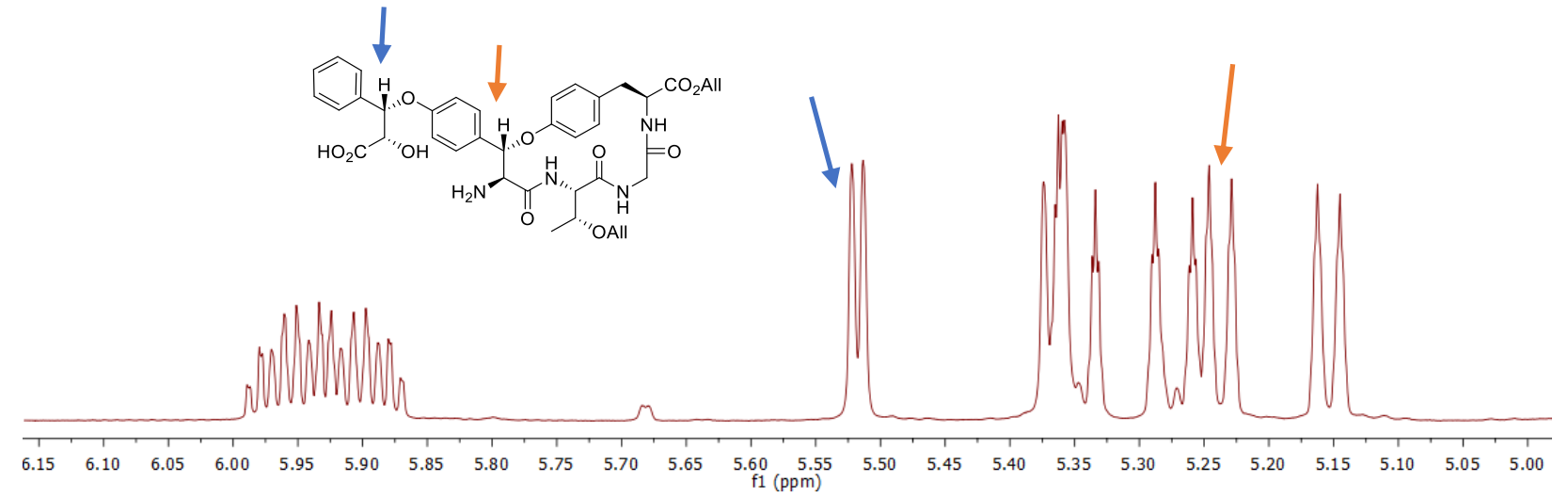


Figure S87: ${ }^{1} \mathrm{H}$ NMR of 27

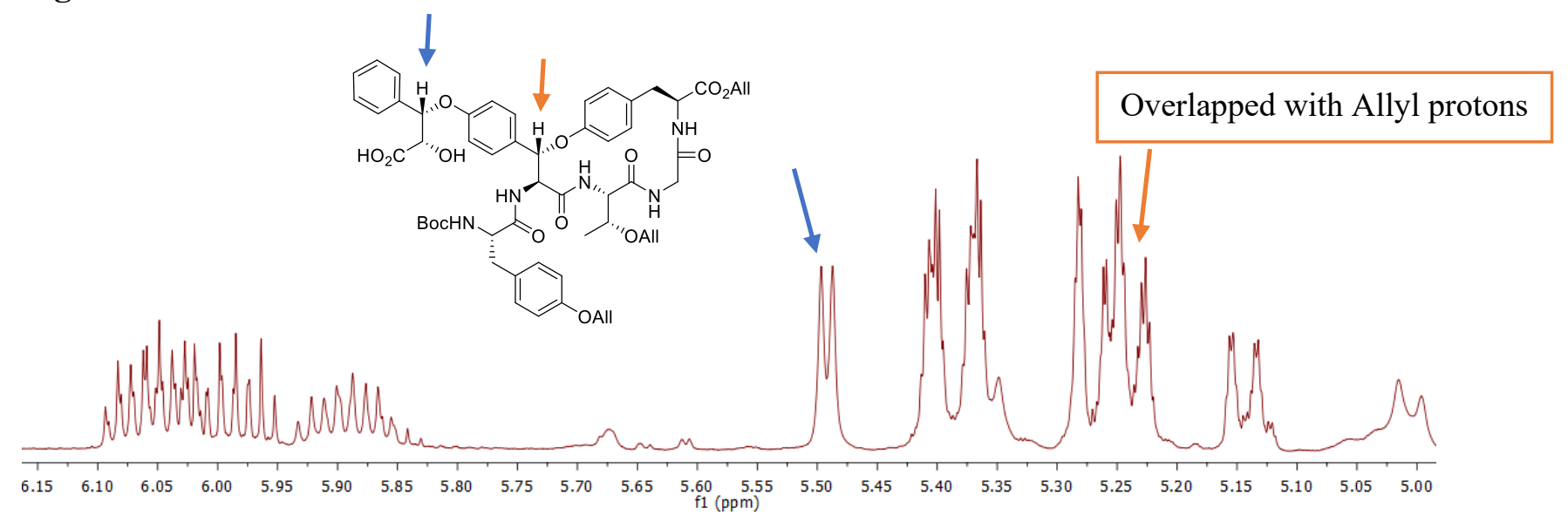

Figure S88: ${ }^{1} \mathrm{H}$ NMR of 28

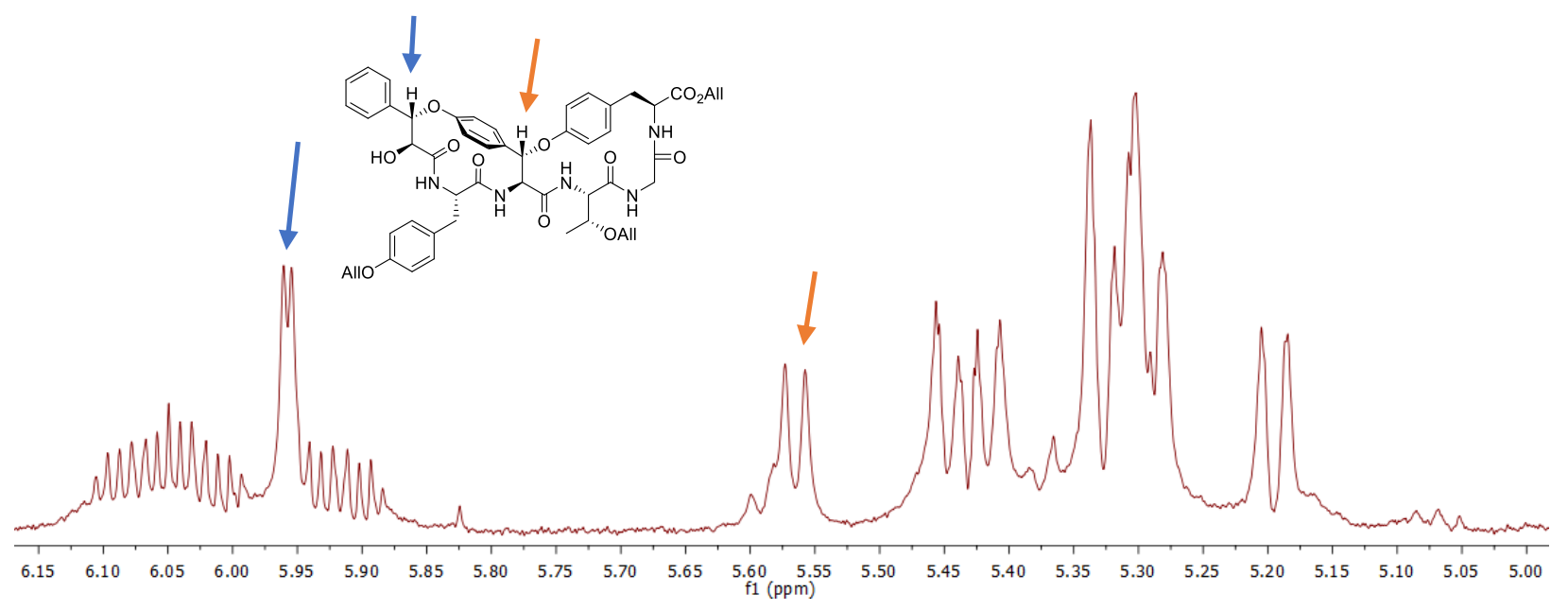

Figure S89: ${ }^{1} \mathrm{H}$ NMR of 29

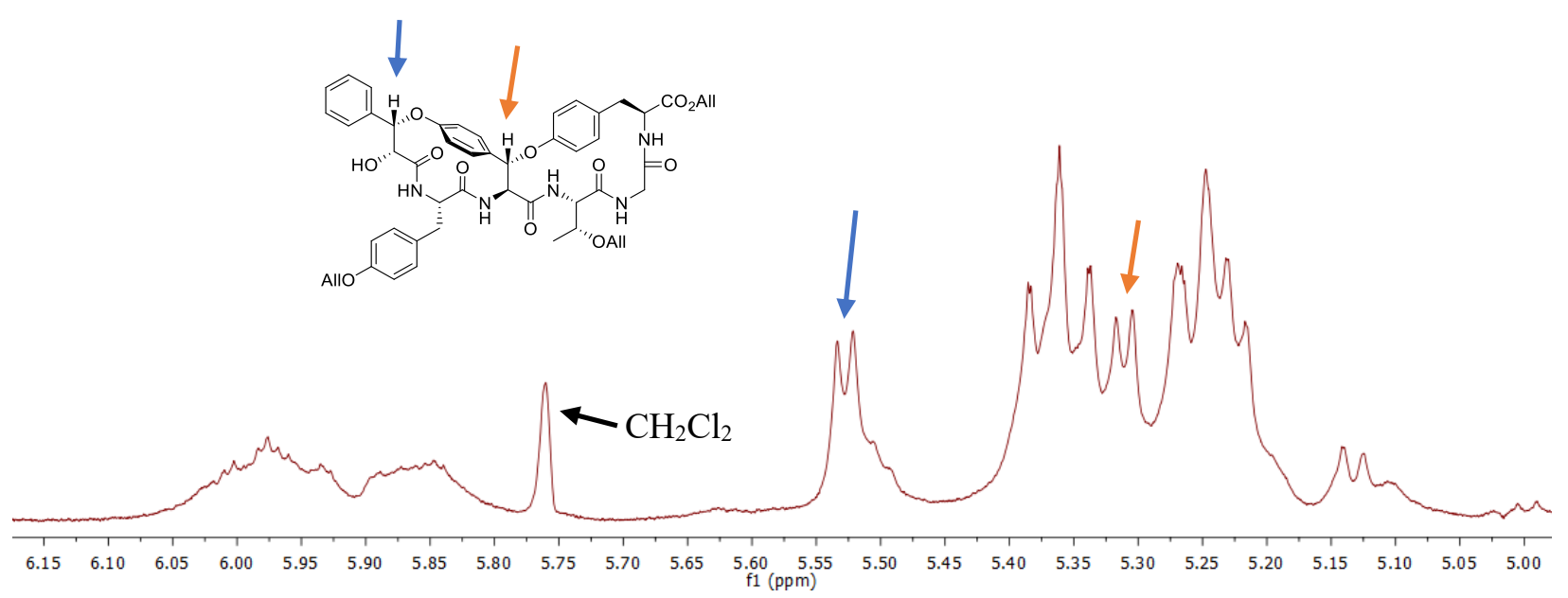


Figure S90: Synthesized asperipin (epi-asperipin-2a) 1

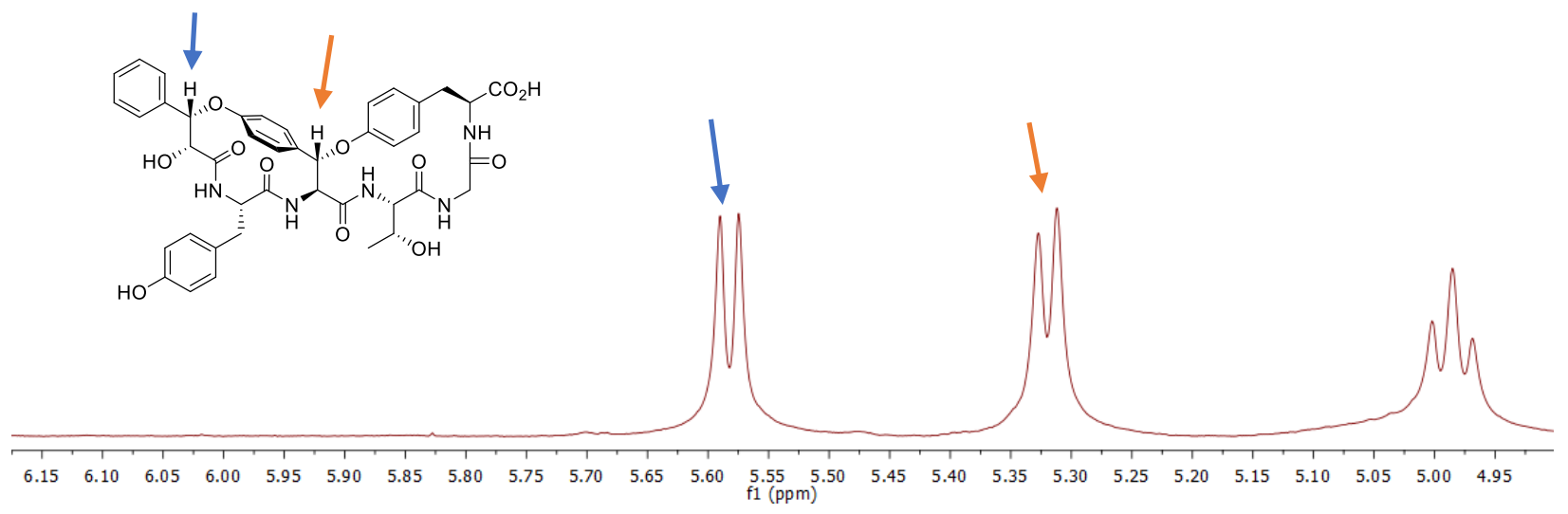

Figure S91: Asperipin-2a natural product

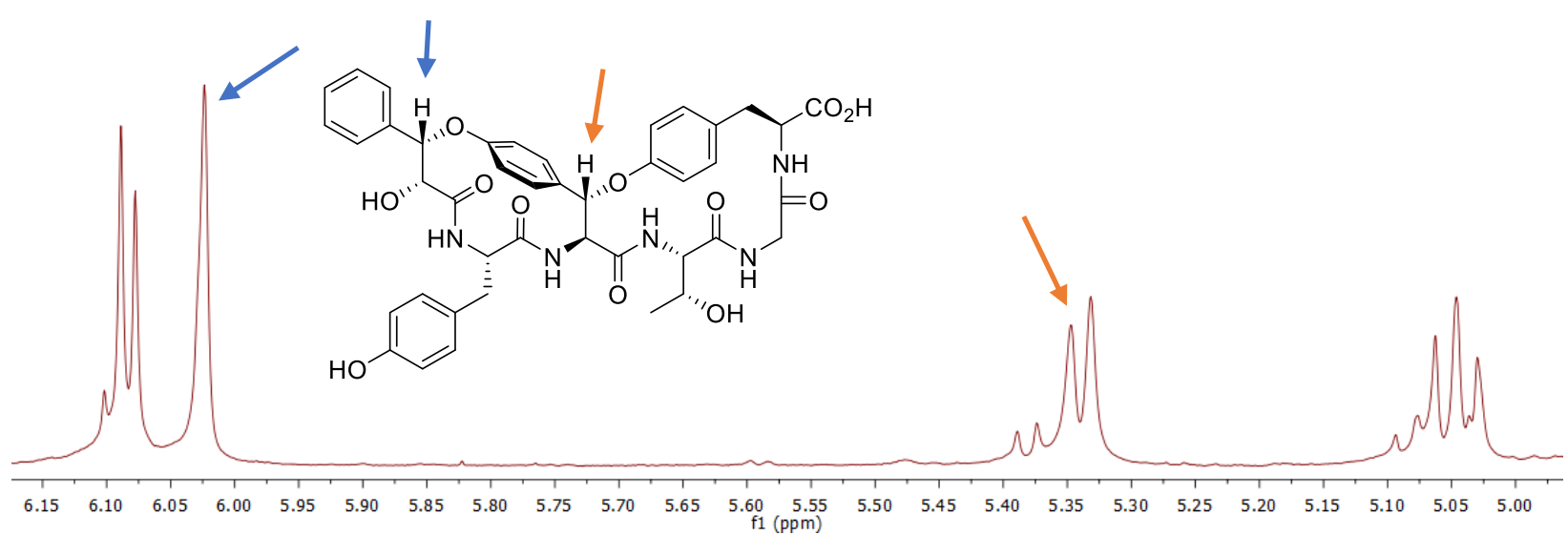


Figure S92: HPLC trace of $\mathbf{1 4}$

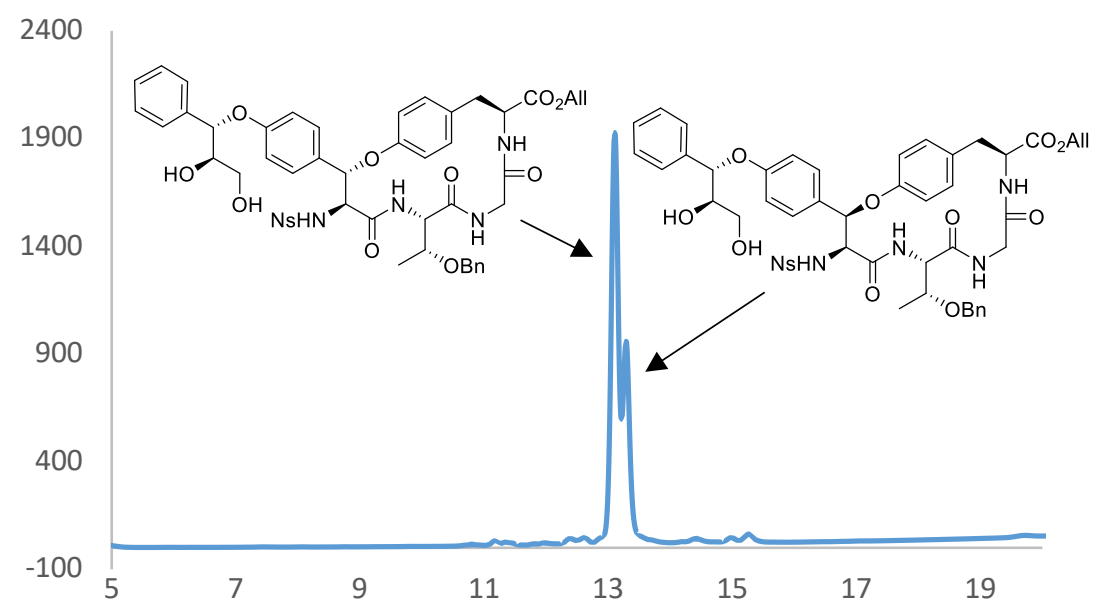

Figure S93: HPLC trace of $\mathbf{1 5}$

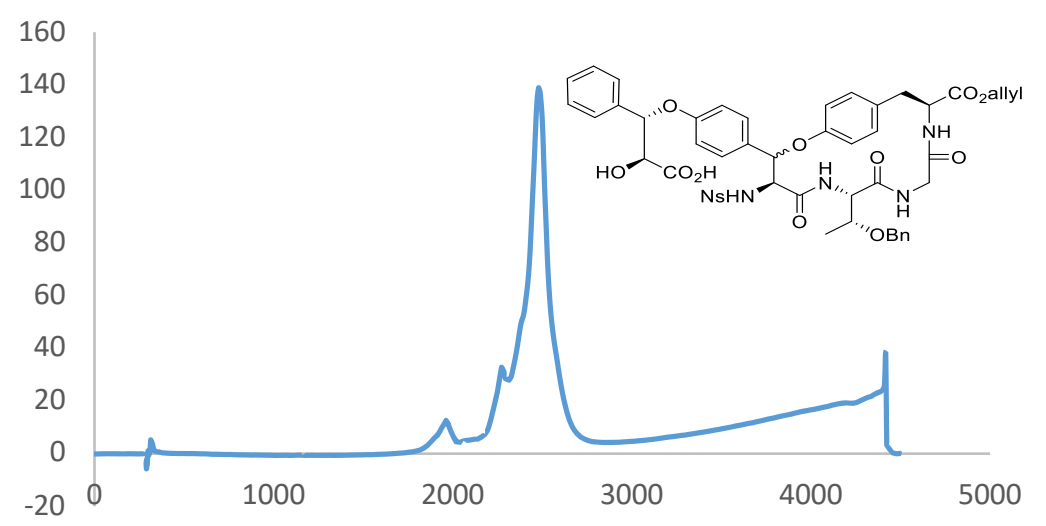

Figure S94: HPLC trace of 17

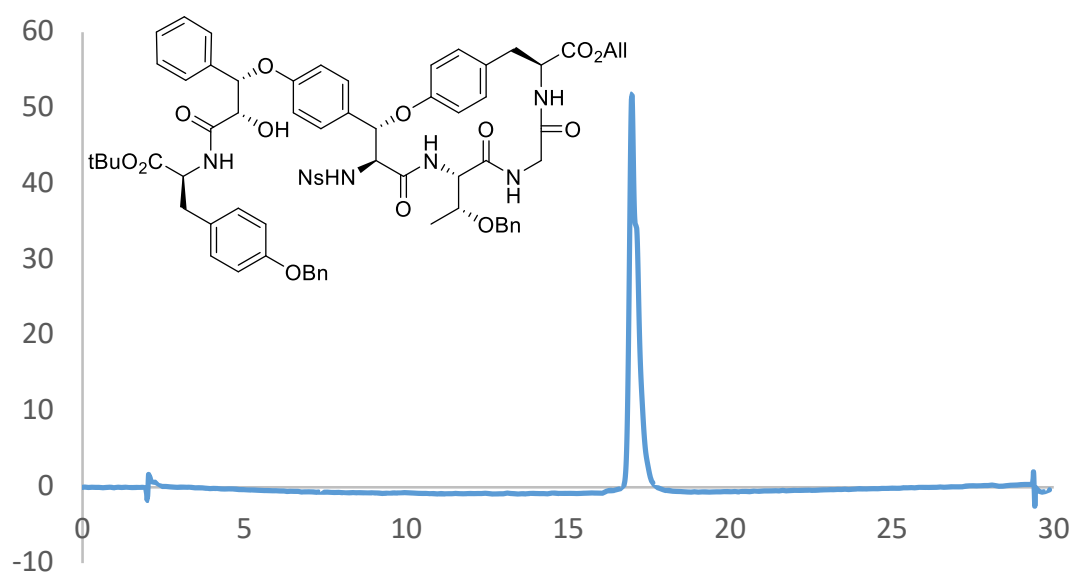


Figure S95: HPLC trace of $\mathbf{1 8}$

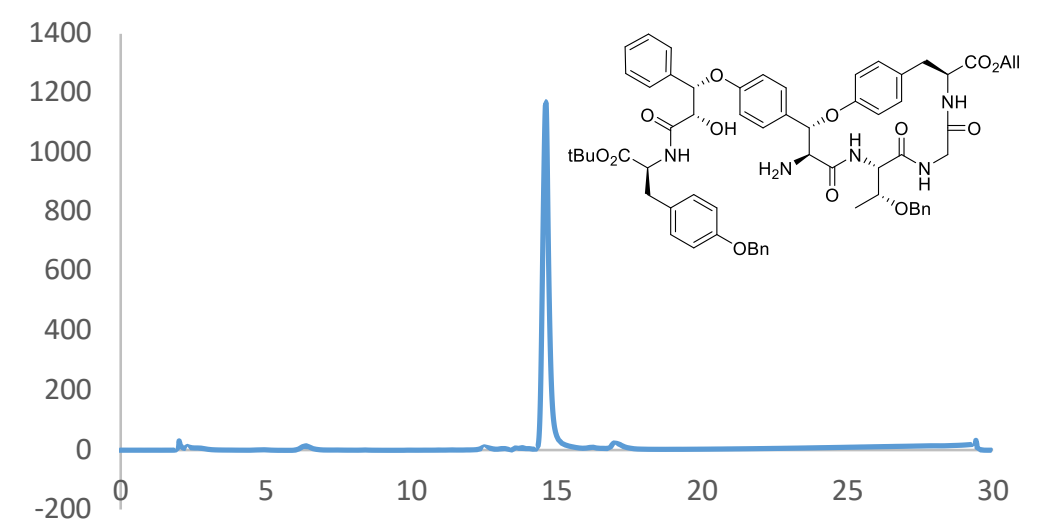

Figure S96: HPLC trace of 19

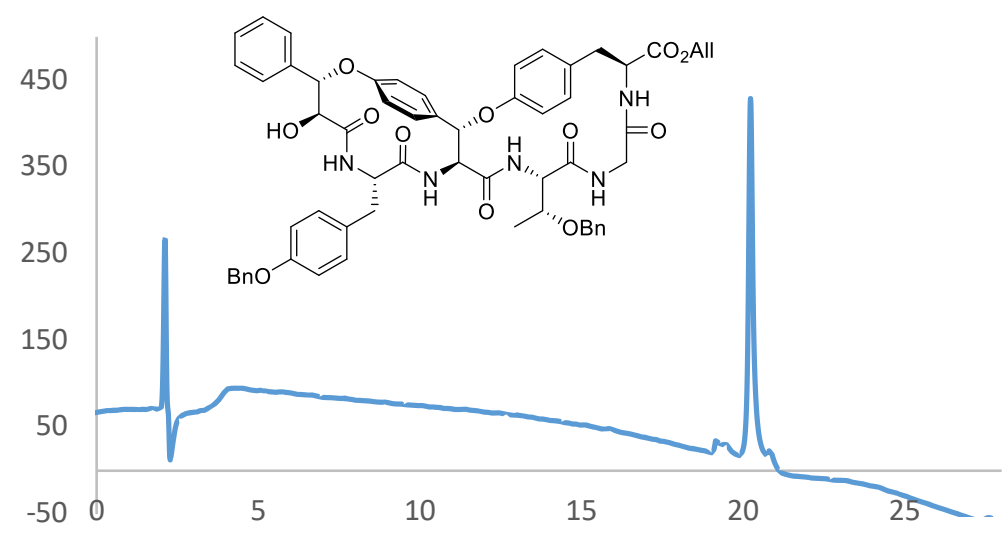

Figure S97: HPLC trace of epimers 19 and 20

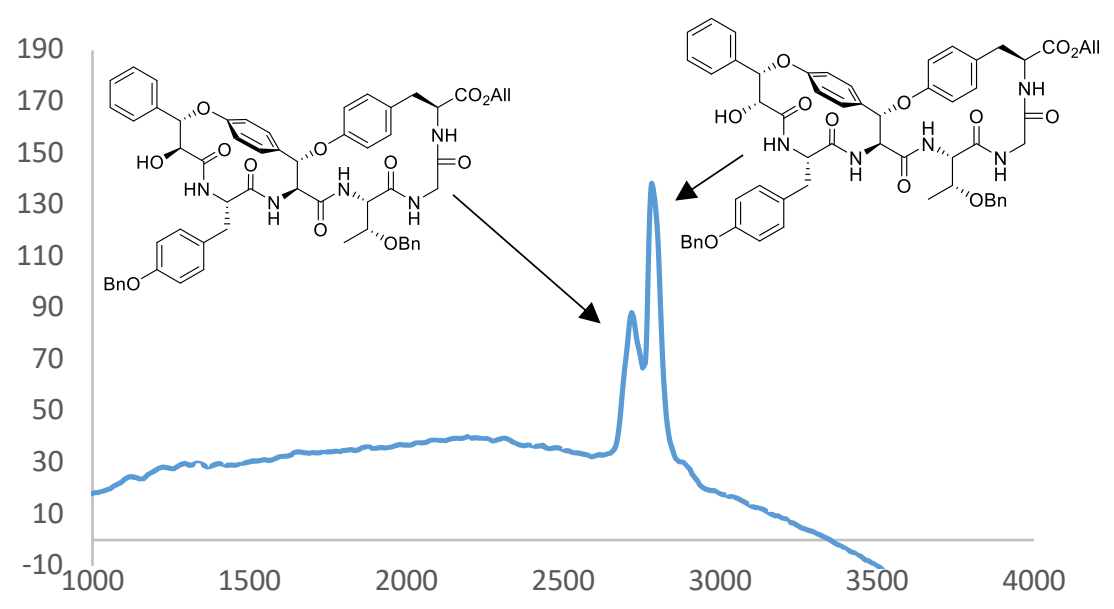


Figure S98: HPLC trace of $\mathbf{2 3}$

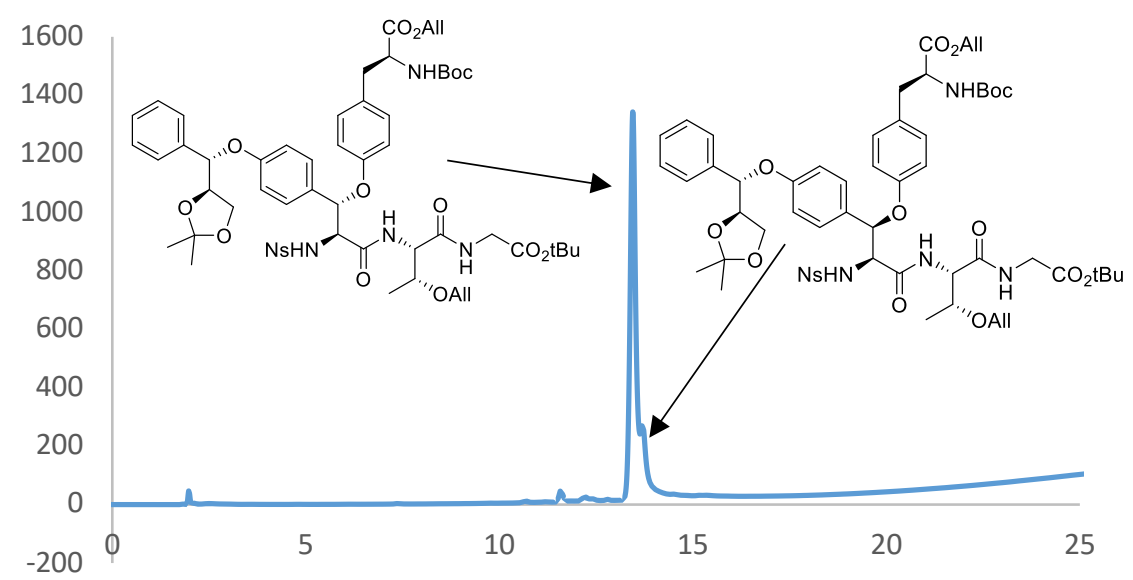

Figure S99: HPLC trace of $\mathbf{S 5}$

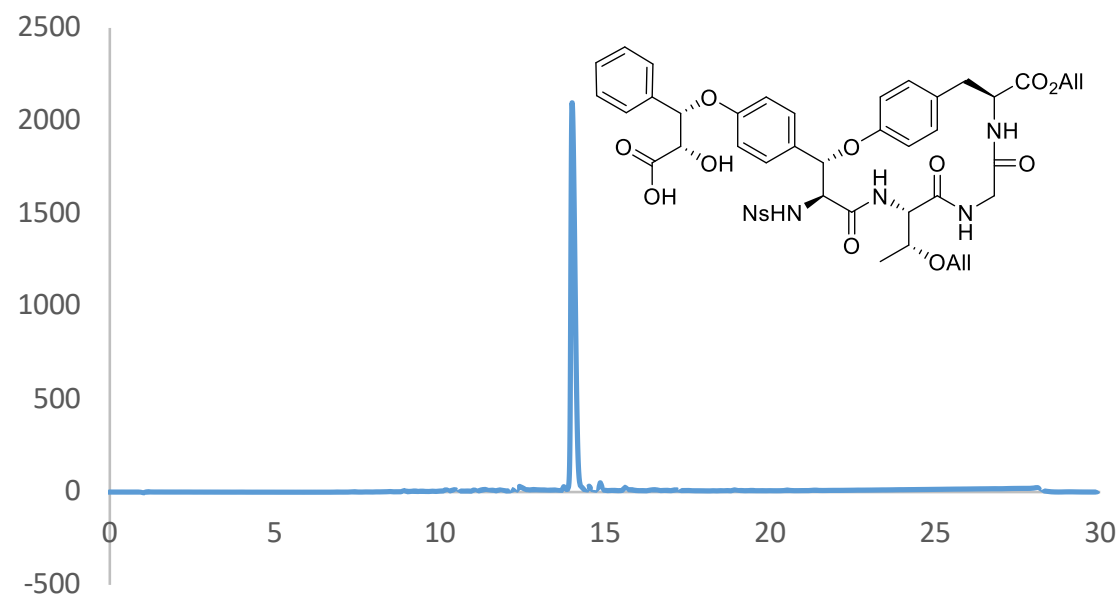

Figure S100: HPLC trace of $\mathbf{2 5}$

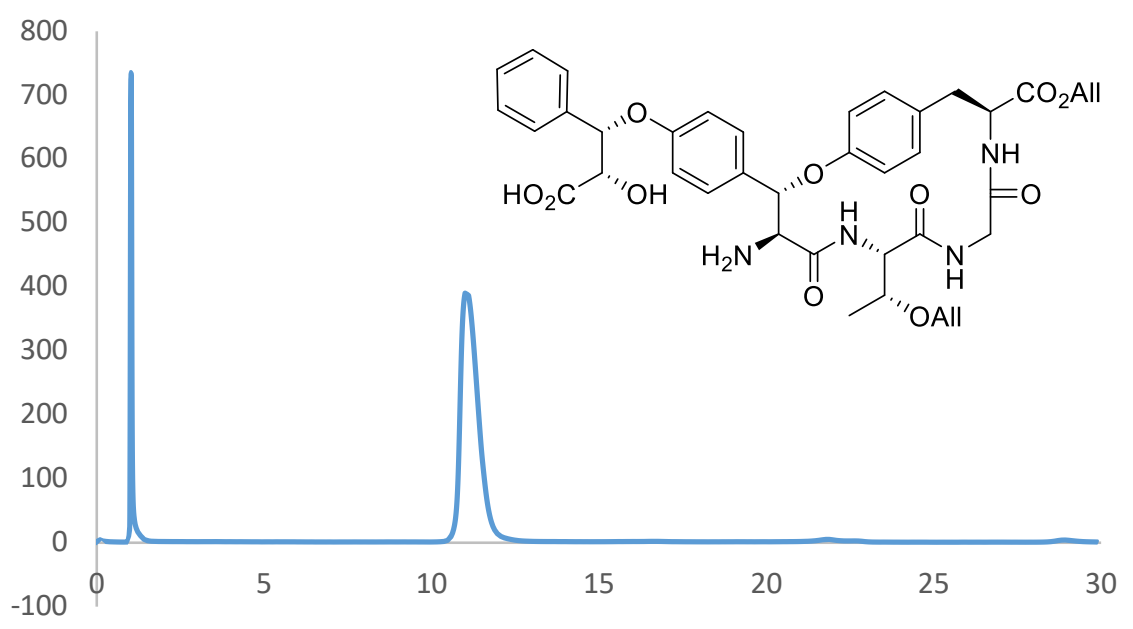


Figure S101: HPLC trace of $\mathbf{2 7}$

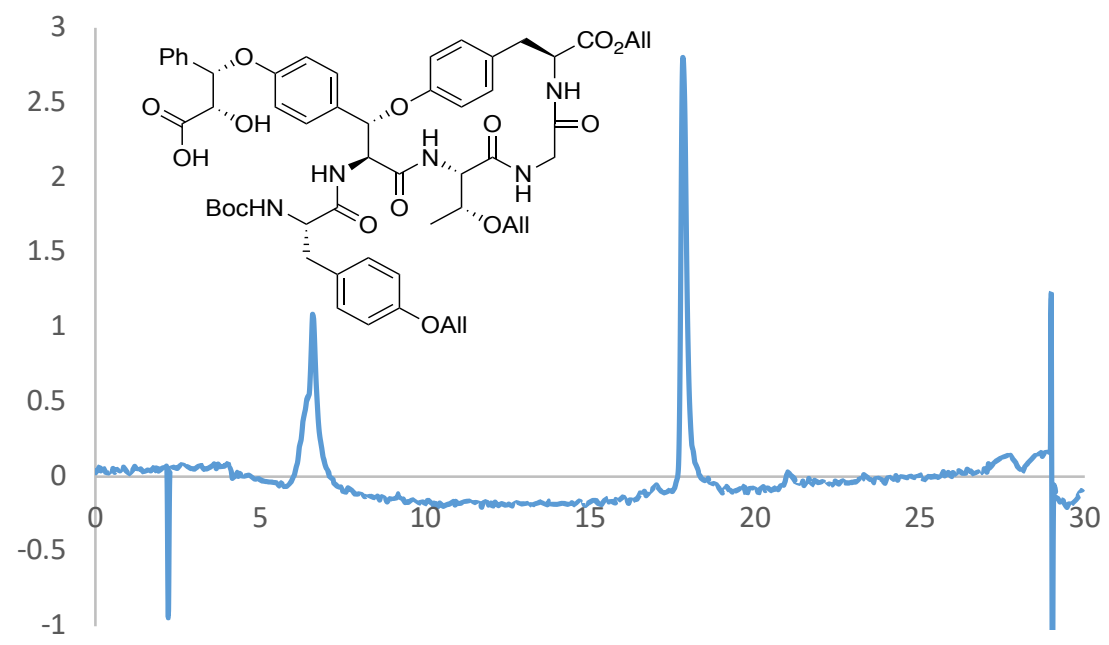

Figure S102: HPLC trace of $\mathbf{2 8}$

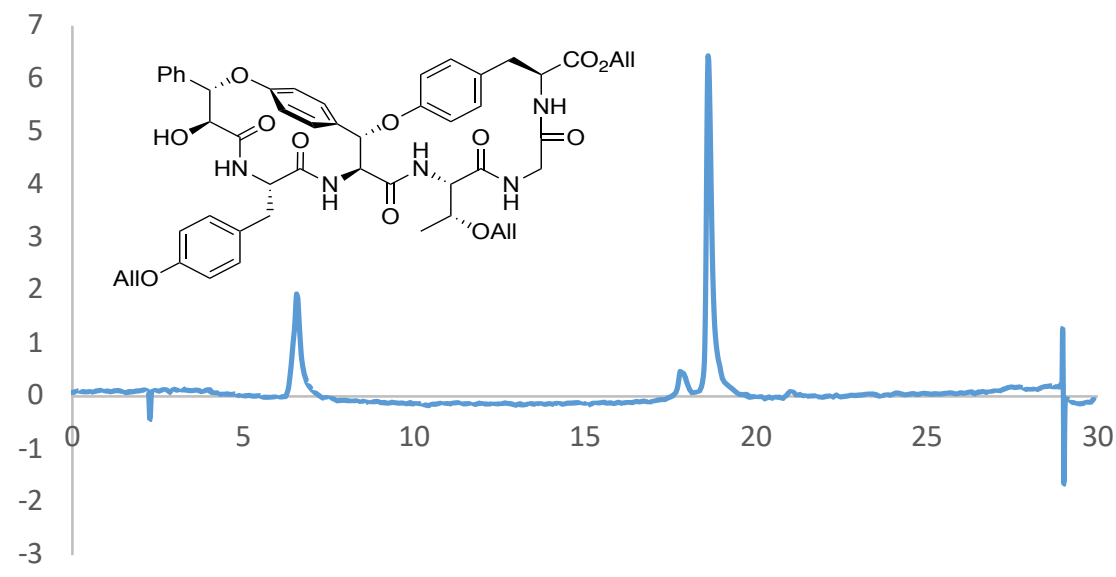

Figure S103: HPLC trace of 29

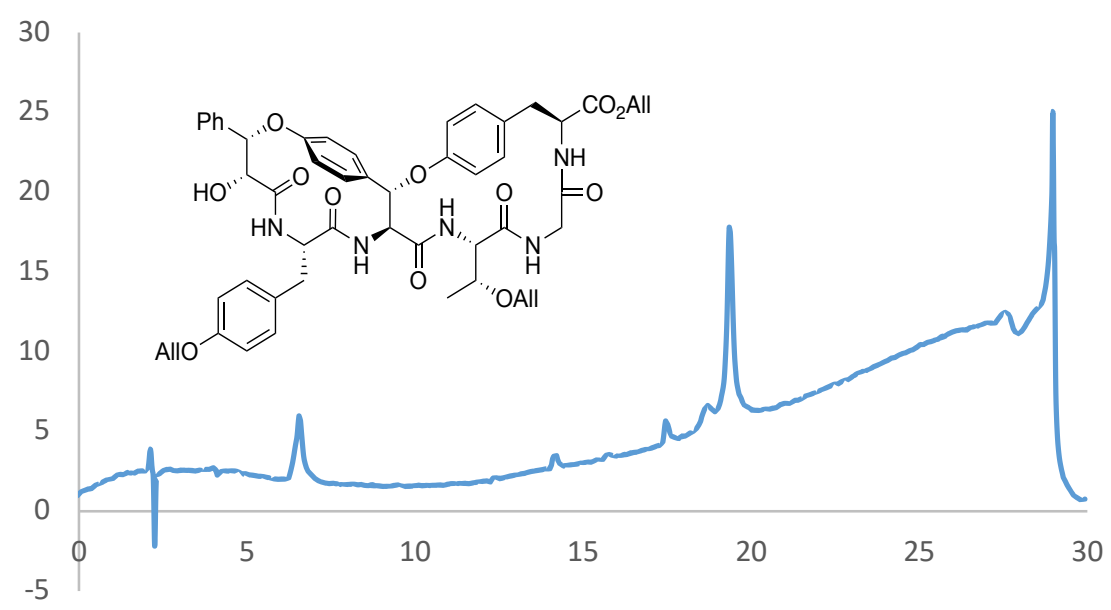


Figure S104: HPLC traces (overlaid) of epimers 28 and 29

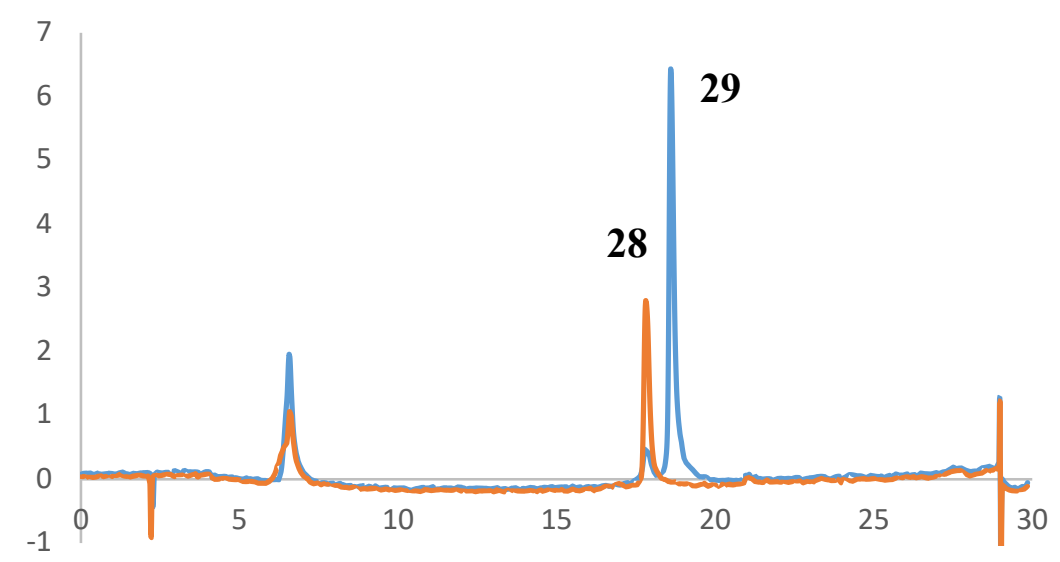

Figure S105: HPLC trace of synthetic asperipin-2a 1 (retention time: 12.14 minutes)

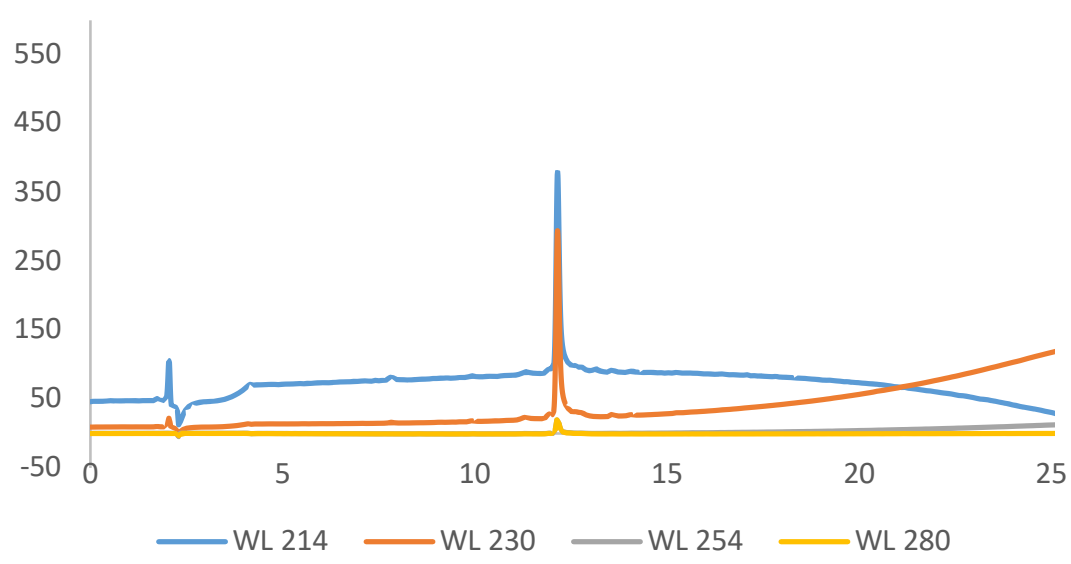

Figure S106: HPLC trace of natural asperipin-2a (retention time: 12.55 minutes)

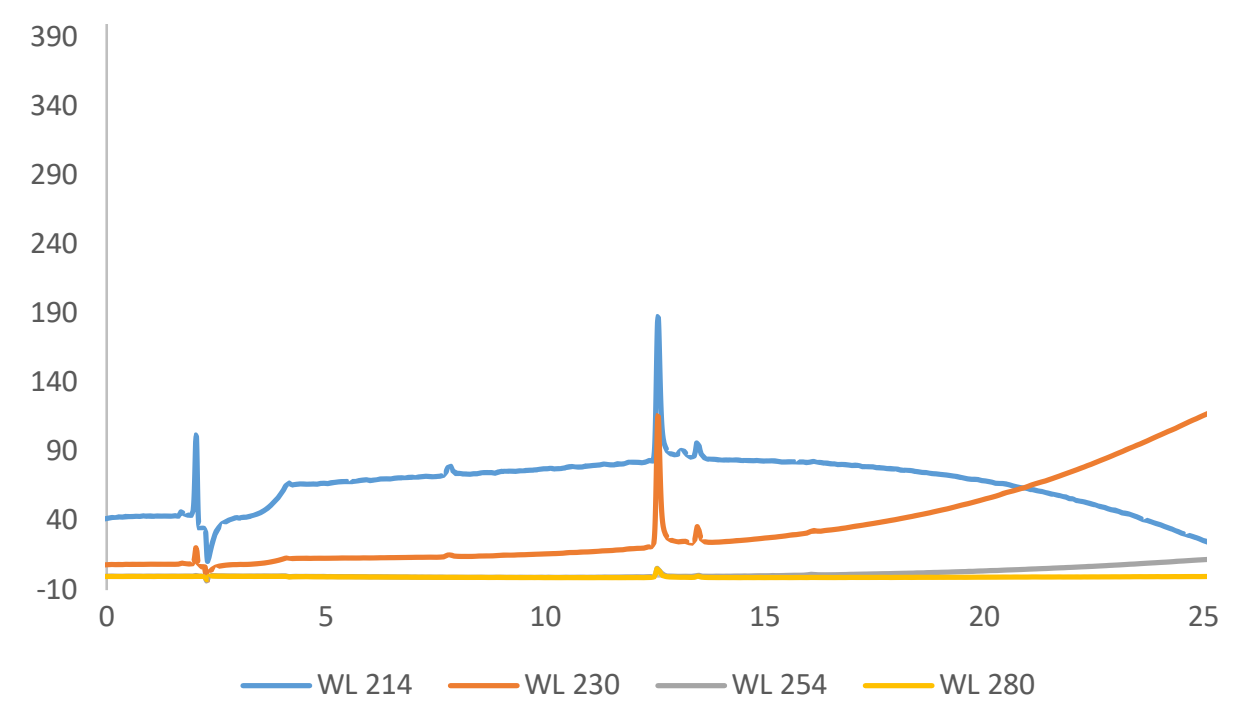


Figure S107: HPLC trace of co-injected synthetic and natural asperipin-2a

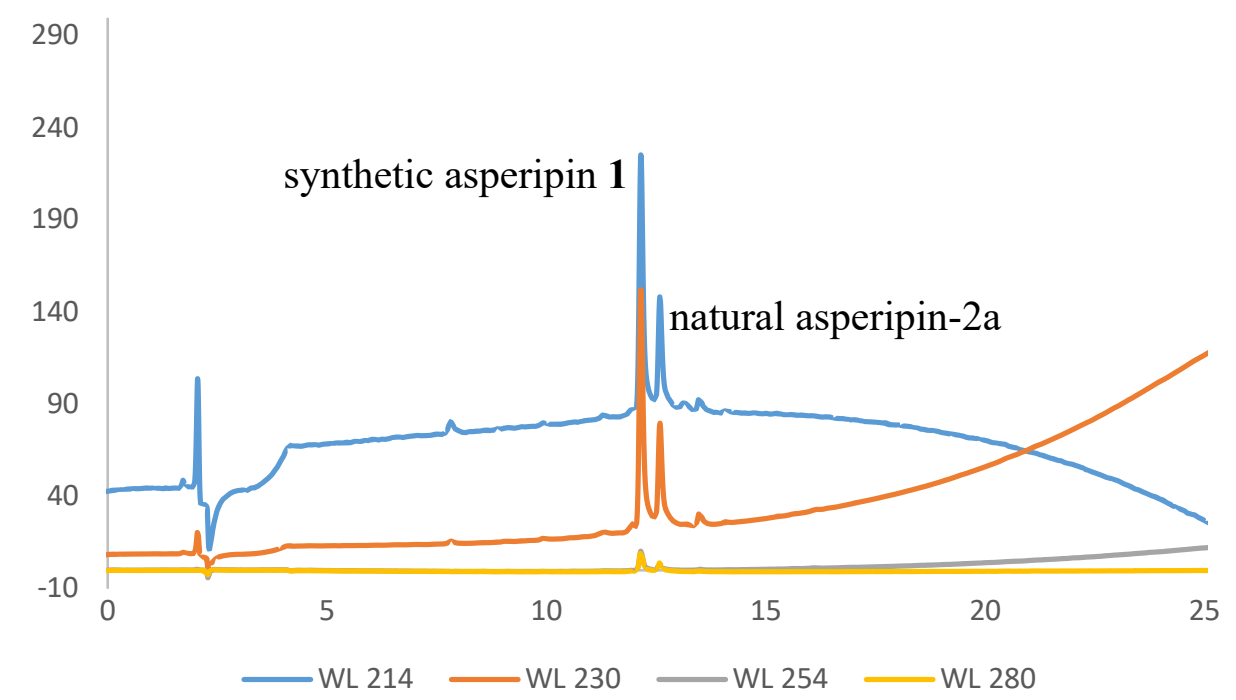




\section{X-ray Crystallography Data}

Crystals of $\mathbf{3}$ were obtained by recrystallization from EtOAc/hexanes. Intensity data for $\mathbf{3}$ was collected on a Rigaku XtalLAB Synergy at 100.0(1) K. Crystals of 14b were obtained by crystallization from acetonitrile/water (HPLC eluent). Data for $\mathbf{1 4 b}$ was collected on the MX1 beamline ${ }^{6}$ at the Australian Synchrotron. The temperature was maintained using an Oxford Cryostream cooling device. The structures were solved by direct methods and difference Fourier synthesis. ${ }^{7}$ Thermal ellipsoid plot were generated using the program Mercury ${ }^{8}$ integrated within the WINGX ${ }^{9}$ suite of programs. Peptide 14b crystallized with three independent molecules in the asymmetric unit, two of these molecules were relatively well ordered, however the third molecule was extensively disordered. The conformations of the macrocyclic portion of the two ordered molecules were essentially identical, however they differed w.r.t the orientation of the p-nitrosulfonyl group, orientations of the other substituents were similar (overlay below).

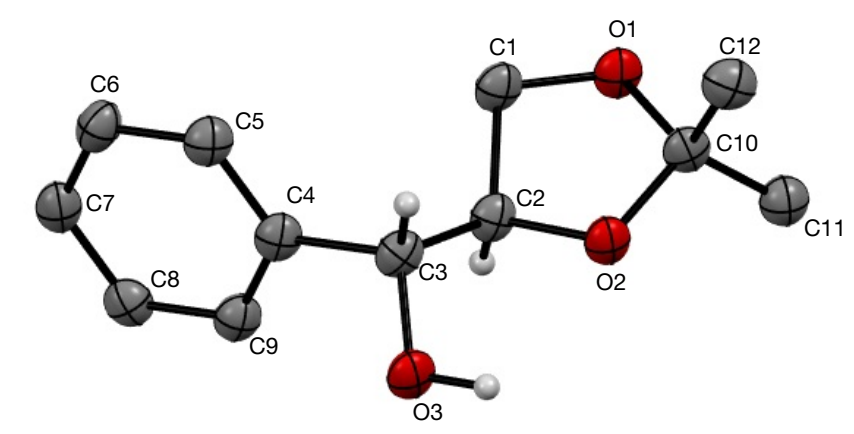

Figure S108. Thermal ellipsoid plot for 3. Stereochemistry defining hydrogen atoms are displayed. Ellipsoids are at the $30 \%$ probability level.

Crystal data for 3. $\mathrm{C}_{12} \mathrm{H}_{16} \mathrm{O}_{3}, M=208.25, T=100.0 \mathrm{~K}, \lambda=1.54184 \AA$, Orthorhombic, space group $\mathrm{P}$ $2{ }_{1}{ }_{1} 2_{1} a=10.8158(4) b=10.5367(3), c=9.4843(2) \AA, V=1080.86(6) \AA^{3}, \mathrm{Z}=4, \mathrm{D}_{\mathrm{c}}=1.280 \mathrm{Mg} \mathrm{M}^{-3}$ $\mu(\mathrm{Cu}-\mathrm{K} \alpha) 0.741 \mathrm{~mm}^{-1}, \mathrm{~F}(000)=448$, crystal size $0.21 \times 0.07 \times 0.06 \mathrm{~mm}^{3}, 12799$ reflections measured, 2244 independent reflections $[\mathrm{R}(\mathrm{int})=0.068]$, the final $\mathrm{R}$ was $0.0516\left[\mathrm{I}>2 \sigma(\mathrm{I}) 2100\right.$ data] and $w \mathrm{R}\left(\mathrm{F}^{2}\right)$ was 0.147 (all data), Absolute Structure parameter $0.06(12)$ 


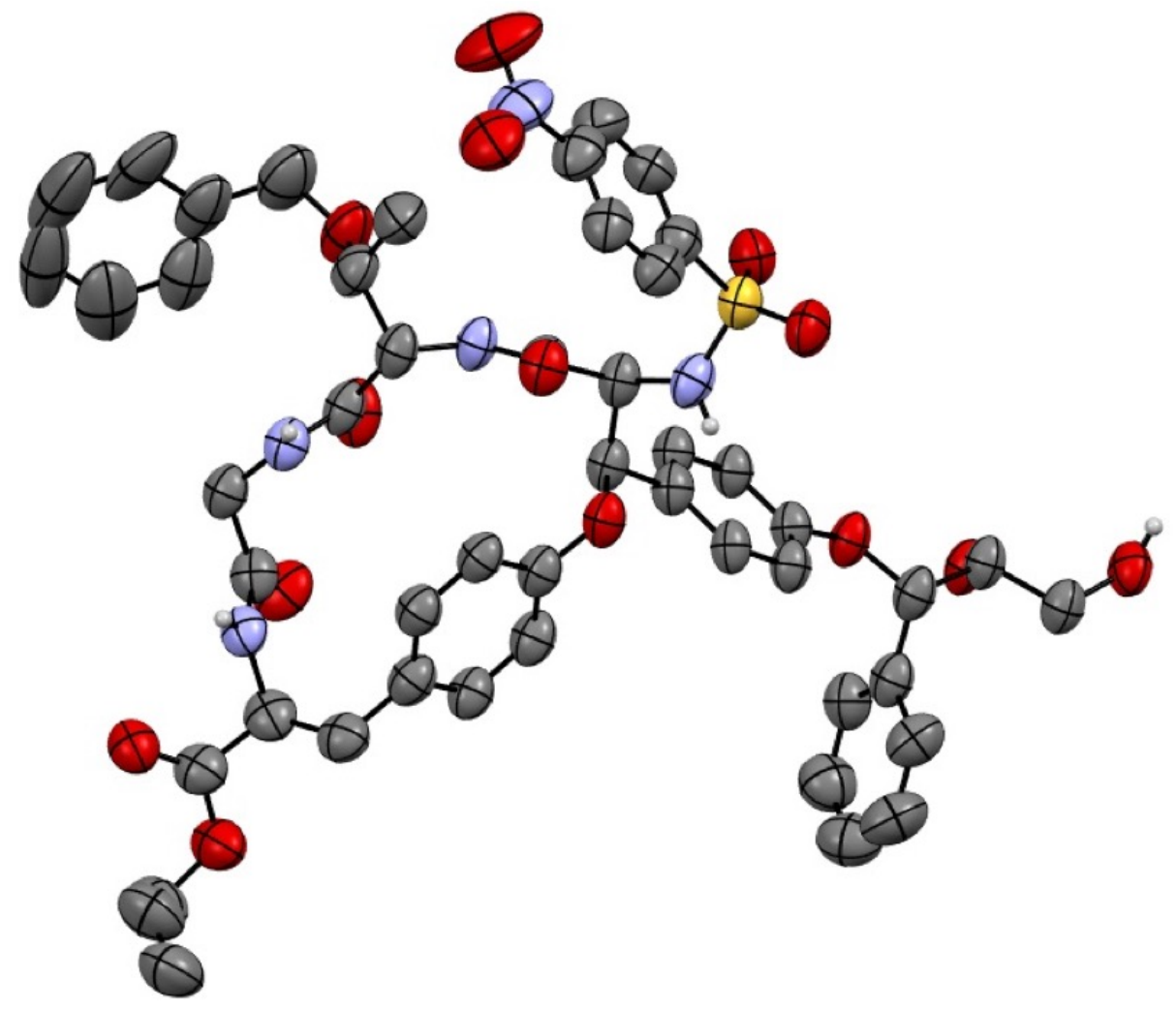

Figure S109. Thermal ellipsoid plot for one of the three independent molecules of $\mathbf{1 4 b}$. Ellipsoids are at the $30 \%$ probability level.

Crystal data for 14b. $\mathrm{C}_{49} \mathrm{H}_{47} \mathrm{~N}_{5} \mathrm{O}_{14}, M=961.97, T=100.0 \mathrm{~K}, \lambda=0.71073$, Orthorhombic, space group $\mathrm{P}$ $2{ }_{12}{ }_{2}{ }_{1} a=9.5120(19) b=27.653(2), c=55.882(11) \AA, V=14699(5) \AA^{3}, Z=12, Z^{\prime}=3 D_{c}=1.304 \mathrm{Mg} \mathrm{M}^{-3} \mu$ $0.137 \mathrm{~mm}^{-1}, \mathrm{~F}(000)=6048$, crystal size $0.20 \times 0.005 \times 0.005 \mathrm{~mm}^{3}, 269999$ reflections measured, 45163 independent reflections $[R($ int $)=0.10]$, the final $R$ was $0.1000\left[I>2 \sigma(I) 21314\right.$ data] and $w R\left(F^{2}\right)$ was 0.33(all data), Absolute Structure parameter -0.03(3) 


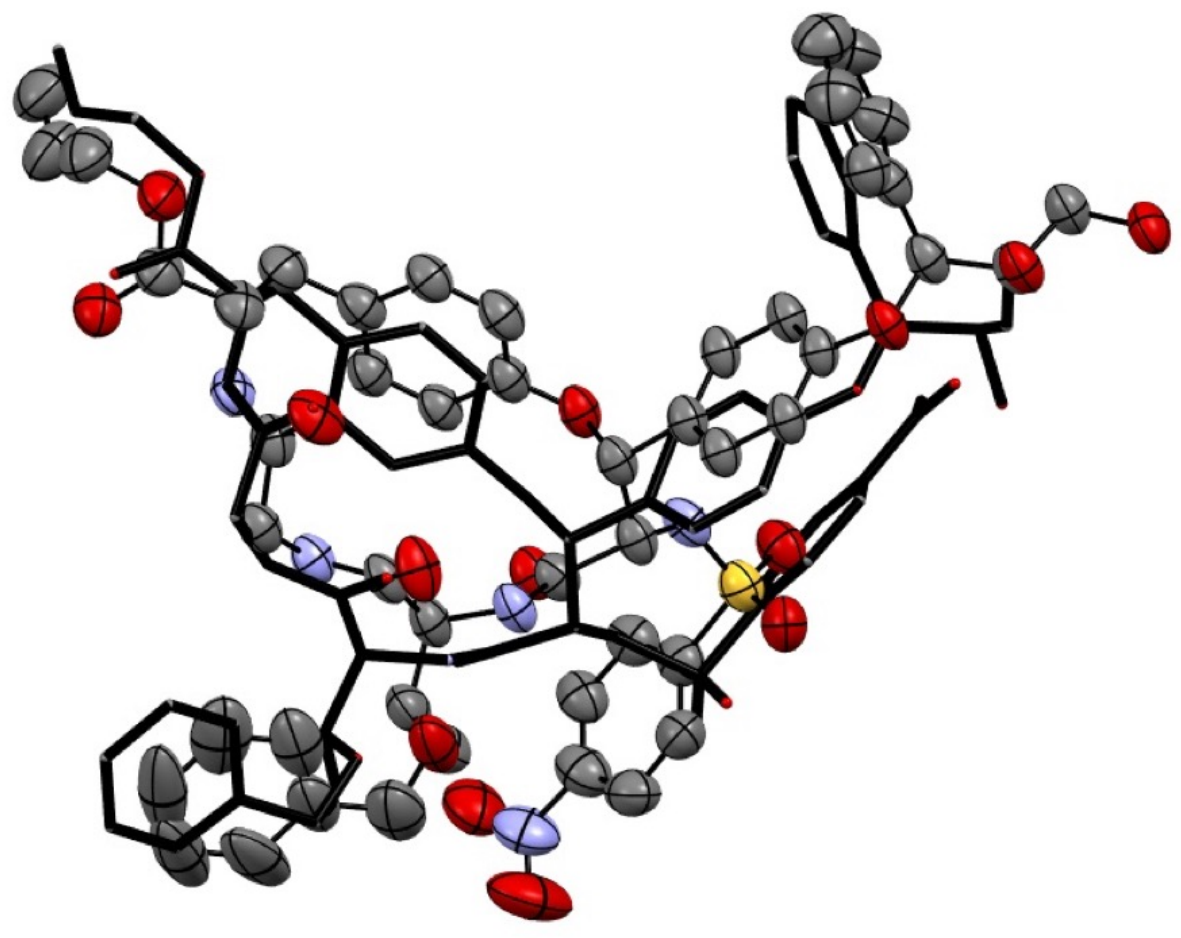

Figure S110. Overlay of the two ordered molecules of $\mathbf{1 4 b}$. 


\section{References}

1. Zhong, Y.-L.; Shing, T. K., Efficient and facile glycol cleavage oxidation using improved silica gel-supported sodium metaperiodate. Journal of Organic Chemistry 1997, 62 (8), 2622-2624.

2. Schmidt, U.; Talbiersky, J.; Bartkowiak, F.; Wild, J., Synthese monosubstituierter (S)-Oxirane von hoher optischer Reinheit. Angewandte Chemie 1980, 92 (3), 201-202.

3. Sato, F.; Kobayashi, Y.; Takahashi, O.; Chiba, T.; Takeda, Y.; Kusakabe, M., Synthesis of the rarely obtained syn-adducts in the reaction of organocopper compounds with 2, 3-Oisopropylideneglyceraldehyde. Preparation of optically active epoxy alcohols. Journal of the Chemical Society, Chemical Communications 1985, (22), 1636-1638.

4. Crich, D.; Banerjee, A., Expedient Synthesis of threo- $\beta$-Hydroxy- $\alpha$-amino Acid Derivatives: Phenylalanine, Tyrosine, Histidine, and Tryptophan. Journal of Organic Chemistry 2006, 71 (18), 7106-7109.

5. Shabani, S.; White, J. M.; Hutton, C. A., Synthesis of the C-Terminal Macrocycle of Asperipin-2a. Organic Letters 2019, 21 (6), 1877-1880.

6. Cowieson, N. P.; Aragao, D.; Clift, M.; Ericsson, D. J.; Gee, C.; Harrop, S. J.; Mudie, N.; Panjikar, S.; Price, J. R.; Riboldi-Tunnicliffe, A., MX1: a bending-magnet crystallography beamline serving both chemical and macromolecular crystallography communities at the Australian Synchrotron. Journal of Synchrotron Radiation 2015, 22 (1), 187-190.

7. Sheldrick, G. M., Crystal structure refinement with SHELXL. Acta Crystallographica Section C: Structural Chemistry 2015, 71 (1), 3-8.

8. Macrae, C. F.; Bruno, I. J.; Chisholm, J. A.; Edgington, P. R.; McCabe, P.; Pidcock, E.;

Rodriguez-Monge, L.; Taylor, R.; Streek, J.; Wood, P. A., Mercury CSD 2.0-new features for the visualization and investigation of crystal structures. Journal of Applied Crystallography 2008, 41 (2), 466-470.

9. Farrugia, L. J., WinGX suite for small-molecule single-crystal crystallography. Journal of Applied Crystallography 1999, 32 (4), 837-838. 